\title{
SURFICIAL GEOLOGY
}

OF THE

HORNE LAKE AND PARKSVILLE MAP-AREAS,

VANCOUVER ISLAND, BRITISH COLUMBIA

\section{DISSERTATION}

Presented in Partial Fulfillment of the Requirements for the Degree of Doctor of Philosophy in the Graduate School of The Ohio State University

by

JOHN GLADSTONE FYLES, B.A. Sc., M.A. Sc.

The Ohio State University

1956

Approved by

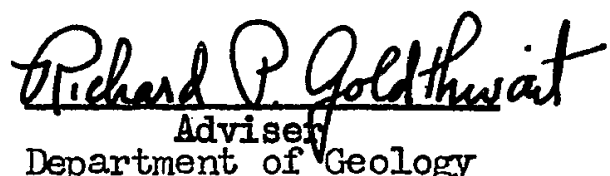


To Jane,

who has stood beside mo

throughout this project. 


\section{ACONOLIELCANASS}

Miss report is based upon my fjeld work for the

Geological Survey of Canada durlnge the surners of 1050 to 1953. I

2an most gratefui to the Geological Surrey for permission to use the

results of this hork for this dissertation, and for the complete

freeciom that I have been given to orgenjae both the field hork and

the accompenying office and laboratory studies as a thesis project.

It is a pleasure to sclmowledge the friendly adrice and hely of Dr.

J. B. Armstrong of the Geological Survey of Canedr, under hose

direction the fiseli project ras begun. Some of the concepts set

forth in this report have been developed jointly rith Dr. Amstrong.

Special thanks are due to Dr. R, P. Goldthrait of the

Geology Department at the Ohio State Dniversity for his friendly

guidance and meny courtesses during his supervision of ny

dissertation hork and for underteking, at considerable expense, a

f1eld examination of the features described berein.

Able assistance in the fleld was rendered by $\mathbb{H}$. Go

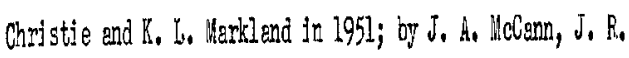

Southwell, and J. Teresmae jn 1952; and by R. L. Craig and J. $X_{\text {. }}$

Gregory in 1953. Thanks are due to P. J. Fraser and $W_{1} R_{\text {. }}$

Hellhood for carrying out sone of the inechanical analyses.

I an grateful to the residents of the map-erea for many

courtesies and services, and particularly to the logging operators

for pernis ssion to use their private roads.

Chapten l, Introciction

Description of area................................ I

Nistere of investigation.............................. 3

Pretrious Hork.......................................... 5

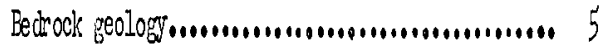

Chapter 2, Phrsiography............................................ 8

Coastal lovilando..................................... 8

Alberni Valley....................................... 10 10

16ortains and mountain valleyso..................... 12

Chigin of mountains and lorilands.............

Glacial sculpture................................ It

Chapter 3, Stratigraphy and nomenclature of suriicial ceposits... 21

"Standand" succession................................. 21

History of nonenclature ................................... 25

Chapter L, Sub-Jashrood deposits................................... 34

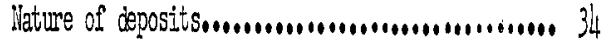
Origin, extent, and correlation, ..................... 36

Chapter 5, Dashisood grompon......................................... 38 Iill of the Deshwood groupon...n..................... 38 laterials and field relations.................. 38 Comparison with till of the Vashon groupo...... Associated glacial movenents.................... Laminated clagn........................................ L L

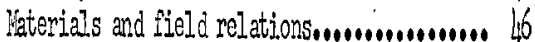

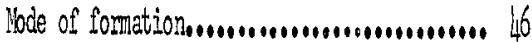

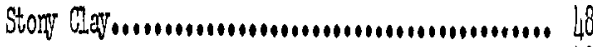

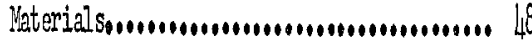

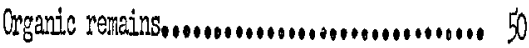
Contacts and thicknesson......................... th

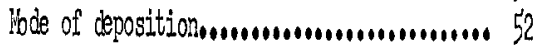
Distribution of the Dashrood group within the asean. 53 Correlative deposits of the Ceorgia cepression...... 55

Chapter 6, Quadra groupo.............................................. 57 Befinition and conponents............................. 5? Peaty beds of the Quadira groupon....................... 58

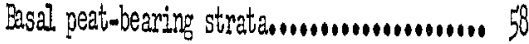
Peativ becis of the Comox sea cliff............... 66 Chef Greek section.............................. 68 Crganic remainsson............................. 70

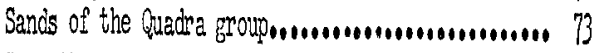
Leposits probably equivalent to the Ruadra group.... 82 quadra sediments outside the map-area.................. 87 Wode of origin of the quadra sedinents ................ 88 Sub-Vlashon erosion surface.n.......................... gl 
Magnitude and age of the non-glacial interval........ 94

Chapter 7, The Vashon group and the last regional glaciation..... 97

Definition................................ 97

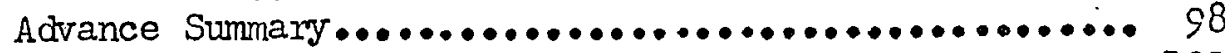

Ground Moraine deposits of the Vashon group........... I00

"Type" Vashon till.s......................... 101

Other ti]Is of the coastal. Iowland........... III

Mountain and valley ti]ls................. Il3

Alberni Valley tills.................... II9

Glaciofluvial and glaciolacustrine features.......... 126

Alberni valley.......................... 127

Esker system...................... 127

Great Central kame and kame-terrace

system...... 128

Sterling Arm terraces................ 132

Somass gravels....................... 133

Mbuntain Valleys......................... I4I

Coastal lowland and adjoining parts of valleys

and mountain slope. 144

Fans and kames, Rosewall creek to Chef

Creek... 1 144

Kame belt, Chef Creek to Hunts Creek..... 146

Spider Lake kame-delta................. I I49

Little Qualicum ice-contact gravels...... 154

Englishman River and vicinity.......... 161

Glacial landslide............................ 165

Glaciomarine deposits.......................... 168

Glacial movements associated with the Vashon group... 169

Glacial movement across the mountains........ 171

Valleys through Beaufort Range............... 173

Cirques and cirque-headed valleys, Beaufort

Range and Mount Arrowsmith.... 176

Glacial movement in Georgia depression........ 177

Glacial movement in Alberni Valley........... I8I

Outline of deglaciation........................ $185^{\prime}$

Strait of Georgia glacier system............. I85

Englishman River glacier.................. 189

Alberni glacier system.................... I90

Age and Correlation of the Vashon group............ 192

Chapter 8, Capilano group.............................. 194

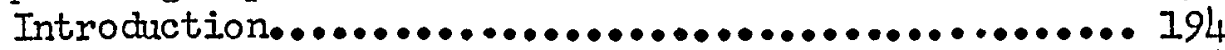

Deposits of the coastal lowland.................... 196 Marine accumulations (including glaciomarine

Nature of deposits..................... 197

Organic remains.................... 201

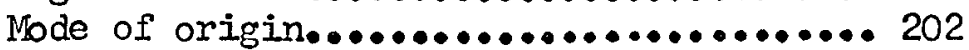


Contents (continued)

Marine veneer........................... 205

Nature of materials................. 205

Mode of occurrence...................208

Tode of origin...................... 214

Derman Island marine deposits.............. 215

Abandoned deltas and fluvial terrace deposits.. 222

Extent of marine submergences in the coastal

lowl and...... 226

Deposits on the floor of Alberni Valley........... 228

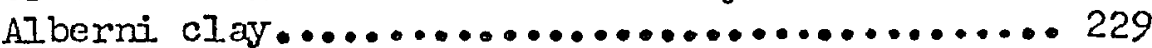

Marine veneer........................... 231

Shoreline features........................ 232

Extent of marine submergence............... 234

Fluvial terrace deposits................. 236

Capilano deposits of the mountainous parts of the

area........ 238

Events recorded by the Capilano group.............. 2li]

Chapter 9, Salish group............................... 245

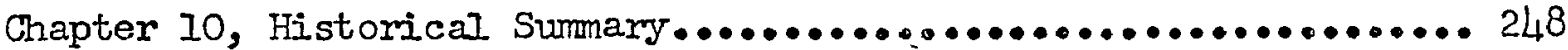

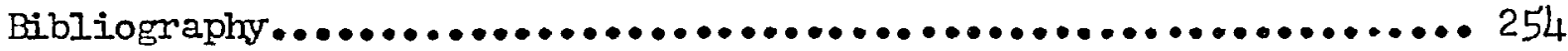




\section{TABLES}

I. Pebble counts of tills and clays of the Dashwood group .... 41

II. Pebble counts of tills of the Vashon group that rest

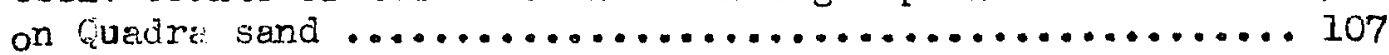

III. Mechanjcal anslyajs date, Capilano group .............. 199

IV. Timit of have washing on hillsides, coastel lowland ..... 227

$V$. Elevations of highest del tas, coastal lowland ...........227 


\section{ILLUSTFATIONS}

Plate If. Surficial geology, Home Lake, Britj sh Columbja ... in pocket Plate IB. Surfjcial geologr, Parisville, British Colunbje...in pocket Figure 1. Lacation of Horne Lake and Parksville map-area ....... 2

2. Bedrock geology and physiographjc divisjons .......... 6

3. Coastal lowland and mountain front from a bill near

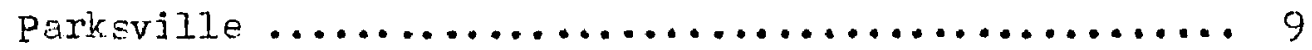

4. View northwest up Albernj Valley from Port Alberni ..... 9

5. View south across Alberni Valley from mounteinsicke

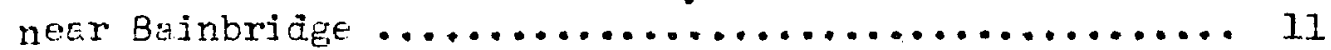

6. Vjew along northeast scarp of Alberni Valley ......... 11

7. View westward up Sprost Lake showing U-shape of valley - 14

8. Ci rque with term, east fece of Mount Arrowinith ........ 19

9. View westward through Cameron Valley .................. 19

10. Stretjgrephjc and environmental chart ............ 22

11. Frposures serving as the basj $:$ for the "standarci".

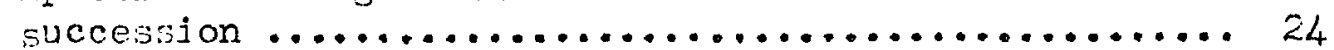

12. Diegrammatic cross-section of a Seattle Hill ........ 30

13. Names and definitions of sroup units ............. 32

14. Grain-sjze distribution of tills of the Dashwood group.. 40

15. Fabric orientation of tills of the Dashwood group and of

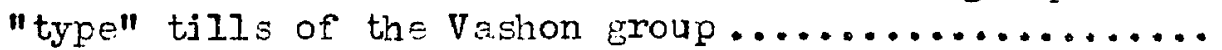

16. Glacjal complex of the Dashwood group ............... 43

17. Grain-cize histograms and inechenjcal analysis dati for stony and Iaminated clays of the Dashwood group ...... 47

18. Stony clay of the Dashwood group ................. 49

19. Large bamacle shells in stony clay $\ldots \ldots \ldots \ldots \ldots \ldots \ldots . . . . . \ldots 9$

20. Distribution of cuadra sedinents .................. 59

21. Part of the basal peaty unit of the Guadra group,

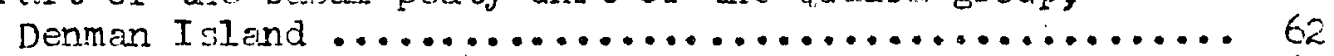

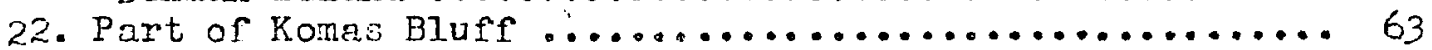

23. Peaty silt layers in sond and silt of the luadra group,

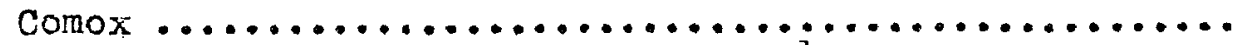

24. Sketch of cut bank, I sland Highway, $\frac{1}{4}$ nille esst of Chef Creek ................................. 69

25. Sands of the Guadra group, Comox sea cliff ........... 77

26. Typi cal Guadra group sand wi th cross lamination restine on coherent sand wi th hoxi zontal lanination ........ 79

27. Grain-size distribution of sands of the Guadra group ... 80

28. Cut bank on the northwest side of Fnglishnan River 2 miles downstreen from the falls ................ 86

29. Northwest end of the Comox sea cljff ............... 92

30. Grajn-size djstribution of "type" tills of the Vashon

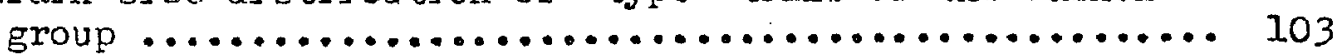

31. Mechanjcal composition of tills of the Vashon group,

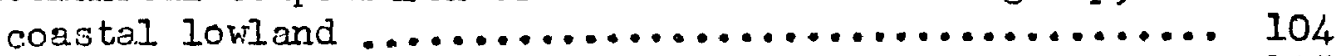

32. Location of samples of Vashon group tills ............ 105

33. Long axis orjentation of pebbles in tills, Vashon sroup. 109

34. Sheared and breccisted sand between quadra sand and

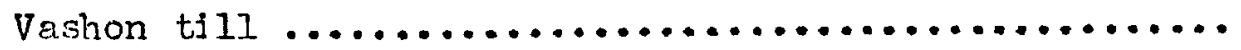




\section{Illustrations (continued)}

Figure 35. Bouldery till on lesis bouldery till, South Englishman

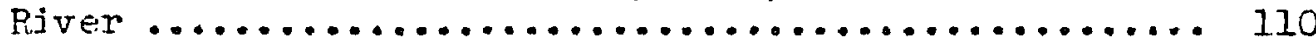

36. Mechanjcal composjtion of mountein tills .......... 115

37. Tills exposed in roed cut, Rosewall. Creek............ 118

38. Aeriel photograph of the northern part of Albermi

Valley thowing drumlinoid ridges .............. 12l

39. Mechanjcal composjtion of tills, Albernj Valley ....... 123

40. Slump or kettle-fjll structures in kame terrace gravel. 128

41. Pjt in gravel hill just north of Johnstone Island ..... 135

42. Hjllside gravel deposjt west of Sonaso River showing

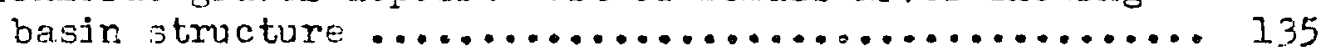

43. Sketch of structures in hillside gravel deposit west

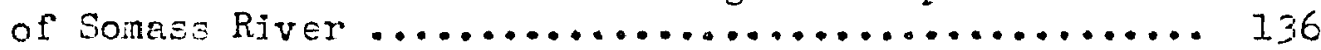

44. Alluvi g.l fans, Rosewall Creek valley .............. 142

45. Remnant of an ice-contact alluvjal fan, headraters of

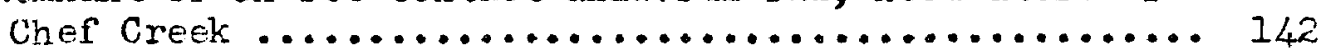

46. Spider Lake terrace ......................... 150

47. Topography of kame and kettle area east of Ljttle

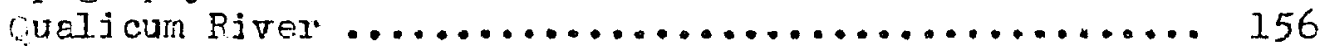

48. Closer view of kame jllustrated in Fi gure $47 \ldots \ldots \ldots . .156$

49. Gravel pit in esker ridge, south of South Englishnan

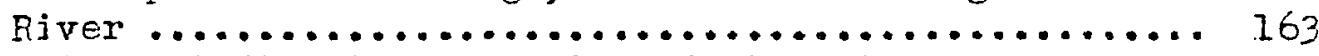

50. Features indicating direction of glecial movement in pocket

51. Stoss-and-lee surfaces, vest wall of Cameron Valley.... 174

52. Glacially moulded rock surfaces, Ballenas Islands .... .774

53. Typjcel coarse gravelly phase of the narjne veneer .... 206

54. Grovelly marjne veneer in which largest stones rest on. underlyjng till .......................... 206

55. Marine veneer containing cley and till-like material .. 209

56. Marine lag gravel resting on Vashon till and Guadra sand .................................... 209

57. Diagramatic cross-section of marine veneer on a slope. 210

58. Cross-section shoring details of marine veneer,

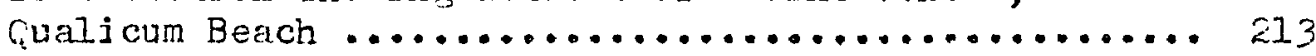

59. Stratigraphic cross-section, Komas Bluff, Denman

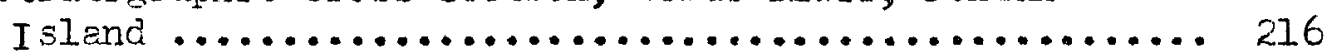

60. Capilano group sands on Komas Bluff, Denman Islend .... 218

61. Komes Bluff, Denman Island, shoring horizontal and

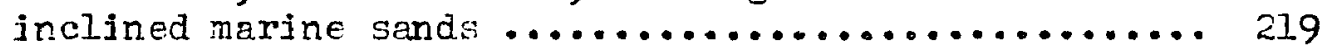

62. Breccia within marine sends, Komes Bluff, Denman Island 219

63. Delta gravels, east side of Inglj shman River ......... 224

64. Stratigraphjc section, same exposure as Fj gure $63 \ldots \ldots .224$

65. Marine wave-cut scarp, Alberni Valley near Spaht Creek. 235

66. Alluvial fan grevel, Rosewall Creek .............. 235 
CHAPTER I

\section{INTRODUCTION}

A thick cover of surficial materials providing a remarkable record of glacial and non-glacial enviroments characterized the IowIands that border Georgia Strait and Puget Sound in southwestern British Columbia and northwestern Washington. This report is concerned with a section of east-central Vancouver Island, comprising the Horne Lake and Parksville map-areas, in which these surficial deposits are particularly well exposed. The location and extent of these areas are shown in Figure 1. Stratigraphic descriptions of remarkable sea-cliff exposures at Comox and Denman Island northwest of the map-areas are included in the report because they provide critical information on the sequence of Pleistocene events. For the same reason, information on ice-movement direction west and south of the map-area is also included. DESGRIPTION OF AREA

East-central Vancouver Island consists of a series of northwest-trending mountain ranges bordered on the northeast by a coastal lowland averaging 4 miles in width. The area described in this report includes a section of the coastal lowland about 40 miles in length, the eastermost range of mountains, and the intermontane Alberni Valley. The last is a basin 25 miles long and 5 miles wide surrounded by mountains and connected to the west coast of the island by a narrow fiord known as Alberni Inlet.

Almost the entire population of the area is found in the coastal lowland and Alberni Valley. The principal centres are the twin cities of Alberni and Port Alberni at the head of Alberni Inlet 


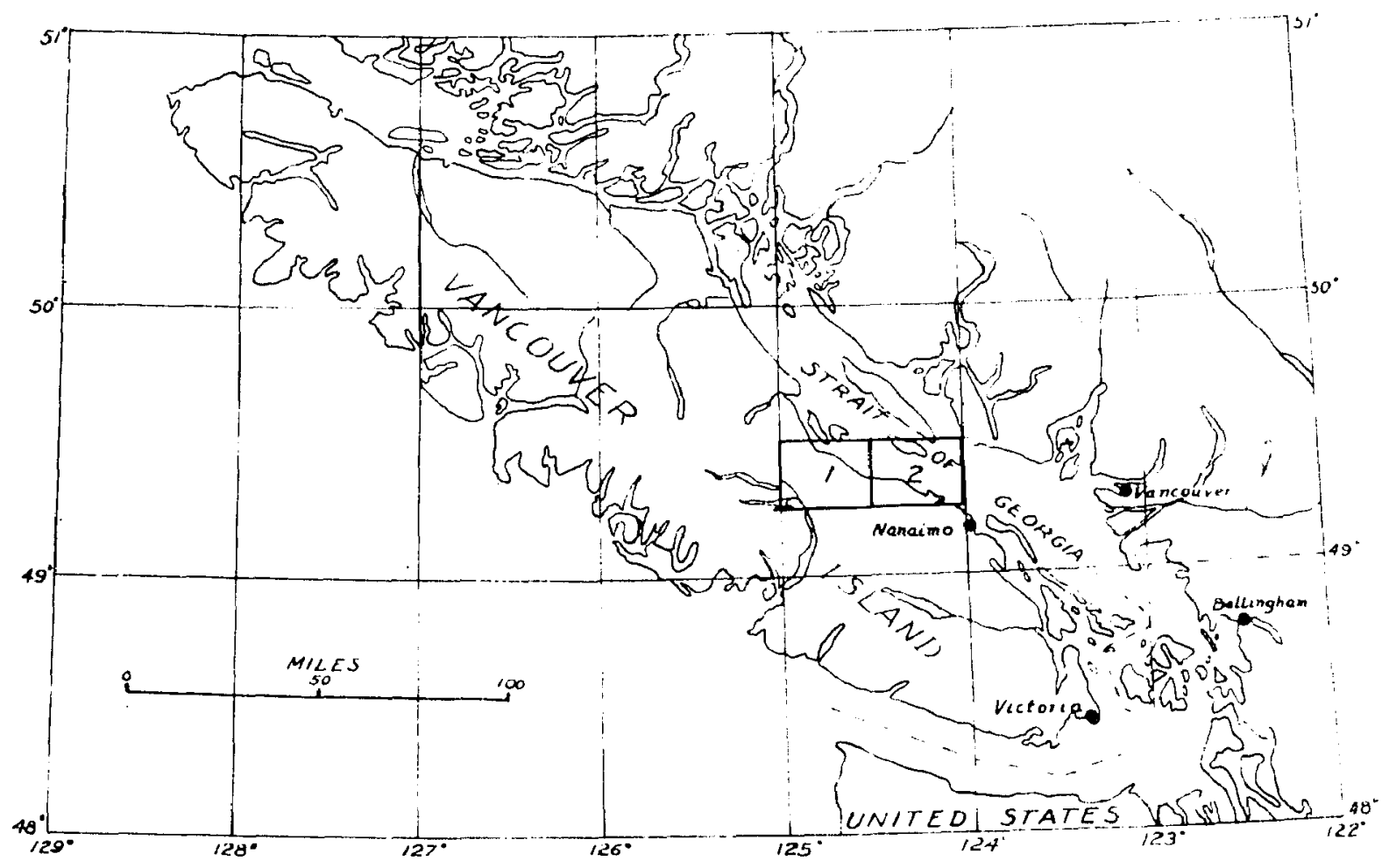

Figure 1. Index map showing the location of the Horne Lake (1) and Parksville (2) map-areas. 
(population about $3500^{1}$ and 8000 , respectively) and the villages of Parksville and Qualicum Beach on the coastal lowland (population about 900 and 800 , respectively). Lumbering is the main incustry of the region and most of the population is employed in logging camps and sawmills during periods, like the present, when the demand for timber products is great. Small mixed farms are scattered through the coastal lowland and Alberni Valley. Commercial salmon fishing is carried on in Alberni Inlet and in Georgia Strait. During the summers, tourists throng the seaside resorts of the coastal part of the area.

A good highway extends along the east coast of the Island within the map-area and a branch highway connects the coastal Jowland with Alberni Valley, via the valley of Cameron Lake. Secondary roads provide access to the settled parts of the coastal lowland and of Alberni Valley while logging roads, in various stages of repair, extend into the unsettled parts of the lowlands, onto the lower parts of the mountain slopes, and into some of the mountain valleys. Dense coniferous forest covers much of the area making foot travel between roads extremely slow and concealing many of the geological features. NATURE OF INVESTTGATIONS

Field work in the Horne Lake and the Parksville map-areas was begun in the later part of the 1950 field season and was continued during the sumers of 1951, 1952, and 1953. Most of the work was concentrated in the lowlands and valley bottoms where unconsolidated deposits are relatively contimuous.

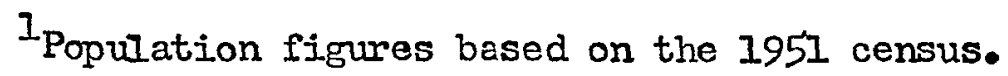


The main object of these studies has been to determine the stratigraphic sequence of the surficial deposits and the succession of environments represented by them as well as by the physiographic features related to them. A second objective has been to provide a map of the unconsolidated deposits on a scale of one inch to one mile. Because of the thinness and discontinuity of many of the stratigraphic units and the lateral gradation of one facies into another, the deposits can be subdivided on a map in various ways. The map presented here (Plate IA, IB) is primarily stratigraphic and only secondarily textural. It attempts to show the stratigraphic divisions of the unconsolidated deposits and the principal facies in each division. It does not undertake to indicate all the textural changes in the materials forming the ground surface. The position of many of the geological contacts which do not outline clearcut landforms has had to be inferred from textural changes in the surface soil, changes in vegetation, and so on; accurate location of these contacts would require much more trenching and augering than is warcanted in work on this scale. Some contacts, marking changes in facies, represent a broad transitional zone and cannot properly be represented by a line on a map. An attempt has been made to show, on the map, the stratigraphy of the unconsolidated materials through which the lowland stream valleys have been cut, even though the nature and distribution of these materials is known only where recent gullying has removed the valley-wall mantle of fluvial and colluvial materials. Hence, the mapped distribution of the various map units on the valley walls is to be considered as tentative. The mountainous parts of the area have been excluded from the geological map. Most of the surficial materials 
of these parts of the area are found in namow valleys and form bodies that are too small to be separated on a map of this scale.

\section{PREVIOUS WORK}

Although several geological reports describe the bedrock of parts of the map-area and together provide a broad outline of the bedrock geology, none gives more than passing attention to the surficial deposits and physiographic features. A report on Alberni Valley by J. D. Mackenzie (1923) contains brief descriptions of the clays and other surficial deposits of the valley, but most of his extensive observations of the surficial materials of the region have never been published, as a result of his untimely death.

Descriptions and interpretation of surficial deposits of the coastal lowland of Vancouver Island northwest of the map-area are included in G. M. Dawson's report on northern Georgia Strait and northerm Vancouver Island (Dawson, 1887, p. 99 and following). The Nanaimo map-area, which embraces the coastal part of Vancouver Island southeast of the map-area, has been described by C. H. Clapp (1914). His report contains a map of the surficial materials as well as notes regarding their occurrence and regarding the associated glacial and nonglacial events.

\section{BEDROCK GEOLOGY}

East-central Vancouver Island consists of basins of soft shale, sandstone, and conglomerate lying upon a basement of altered ba.sic volcanic rocks, altered sedimentary rocks, and small granodiorite bodies (see Figure 2). The basin sediments, termed the Nanaimo group, underlie most of the coastal lowland and Alberni Valley and occur in a few places on the mountains. They are typically rather poorly sorted, 


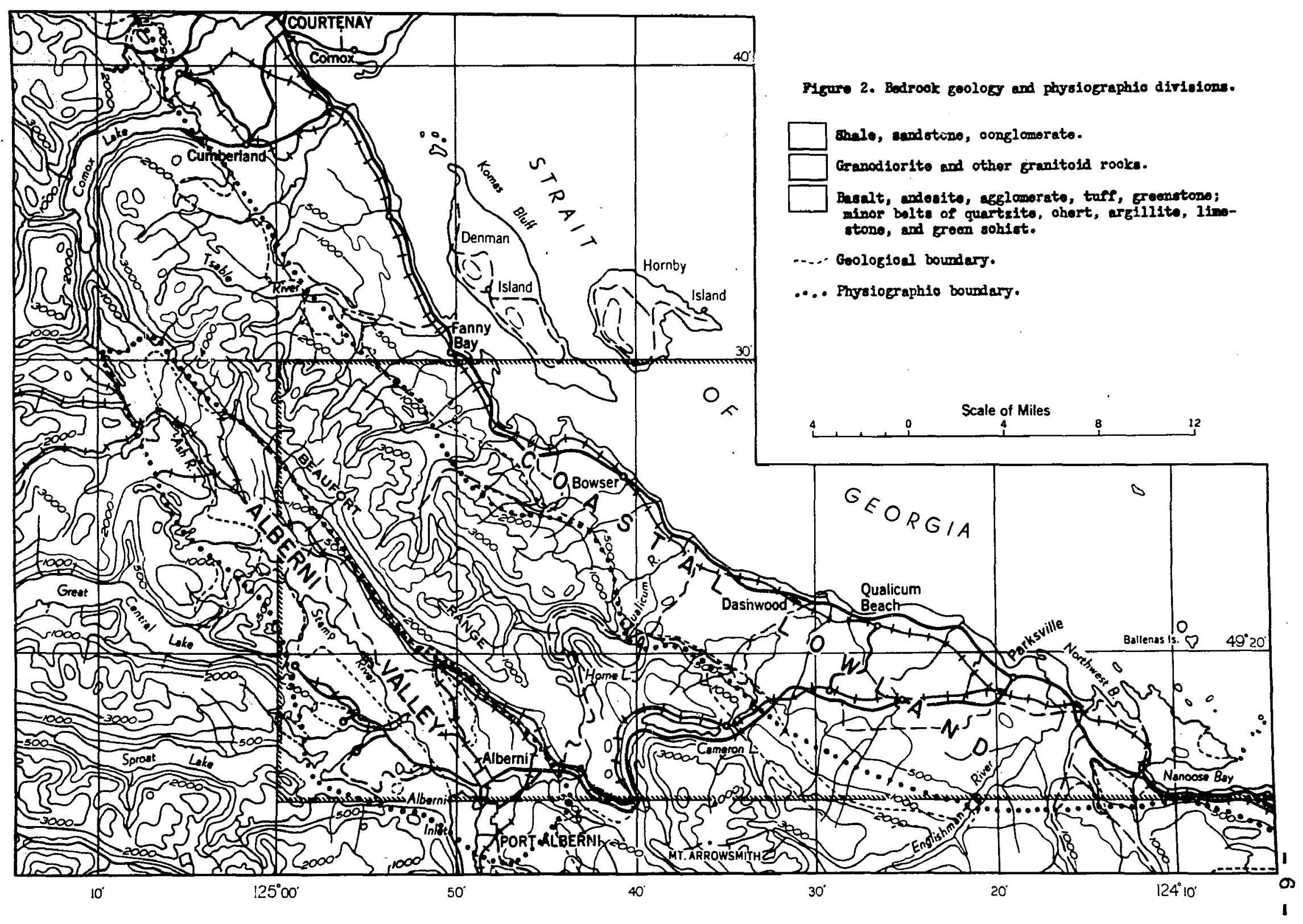


contain an abundance of angular grains of unstable minerals, and are characterized by numerous local facies changes. They are of Late Cretaceous age and include both marine and non-maxine beds. A good summary of the stratigraphy of these rocks is provided by Usher (1952, p. 6-30); their structure and mode of deposition are discussed by Buckham (19li7a):

The basement rocks are principally altered basaltic and andesitic lavas and pyroclastic rocks that have been traditionally assigned to the Triassic Vancouver group. Areally intermingled with these massive volcanic rocks, and as yet incompletely distinguished from them, are belts of quartzite, chert, argillite, greywacke, and green schist, interbedded with Iimestone bodies that Iocally have yielded Permian and possibly Pennsylvanian fossils. These sedimentary rocks are exposed principally near Nanoose (Buckham, 1947b; Richardson, 1874, p. 98) and as a belt extending from Horne Lake to Cowichan Lake (Stevenson, 1944; Fyles 1955).

Small plutons of granodiorite occur along the west side of Alberni Valley, at Nanoose, and along the northeast side of the mountains between Horne Lake and Englishman River; Iarger and more numerous bodies of a similar nature lie to the west and south of the map-area. These granodiorite bodies cut the basement volcanic and sedimentary rocks and are overlain by sediments of the Nanaimo group, but two small granodiorite masses of different and distinctive lithology northwest of Courtenay (Gunning, 1930) have invaded the Nanaimo group. 
CHAPTER 2

PHYSIOGRAPHY

The map-area straddles the boundary between two northwesterly-trending physiographic elements, the Vancouver Island Ranges and the Georgia depression (Bostock, 1947, p. 89, 91). The Georgia depression, separating the Vancouver Island Ranges from the Coast Range and northern Cascade Range, is the northern, Canadian part of a northwest-trending structural valley averaging 25 miles in width and extending 250 miles from the northern end of Georgia strait to the southern end of Puget Sound. It is represented in the map-area by the coastal lowland that borders this part of the northeast side of Vancouver Island, as well as by a few small islands in Georgia Strait (see Figure 2). The Vancouver Island Ranges, which constitute almost the entire island, are typified by northwest-trending ridges and valleys crossed by transverse valleys with preferred north, northeast, and east trends (Peacock, 1935). The two principal elements of the Vancouver Island Ranges within the map-area are a narrow, northwest-trending mountain belt including Beaufort Range and Mount Arrowsmith, which rises steeply from the inland edge of the coastal lowland, and the broad Alberni Valley, also trending northwest, that separates this front range from the more extensive mountains to the southwest.

\section{COASTAL LOWLAND}

Between Georgia Strait and the front of the Vancouver Island Ranges is an undulating lowland averaging 4 miles in width that constitutes the unsubmerged southwest edge of the Georgia depression (see Figure 3). Within the map-area, this lowland surface rises 
gradually from the sea shore to meet the steeper mountain slope at an elevation of about 700 feet, except between Chef Creek and Waterloo Creek where a bench about 1000 feet above sea-level separates the lowland proper from the mountain face. The greater part of the coastal lowland is underlain by shale and sandstone of the Nanaimo group, and, in many places, the boundary between lowland the mountain slope approximates the contact between these sediments and the basement rocks. However, near Nanoose and on the 1000-foot bench between Chef Creek and Waterloo Creek, basement rocks extend into the coastal lowlands. Outcrops are rare except in these areas of basement rocks and, throughout most of the coastal plain, a mantle of overburden several tens of feet to several hundred feet in thickness completely covers the bedrock and controls the topography. The most prominent physiographic features of the coastal plain are sea cliffs and steep-walled river valleys incised up to 300 feet into the thick cover of unconsolidated materials. Between these valleys, the ground surface is characterized by gentle slopes and by broad ridges and depressions with local relief of less than 100 feet.

\section{ALBERNI VAILEYY}

Alberni Valley (see Figure 4 ) is a northwest-trending structural depression 25 miles long and averaging 5 miles wide lying within the Vancouver Island Ranges. Although it is completely surrounded by mountains, it is connected to the Pacific Ocean by the narrow fiord valley of Alberni Inlet (Figure 5). The axis of the floor of Alberni Valley is at sea-level where it meets the head of this fiord valley and rises gradually to 1500 feet above sea-level at its northwest 


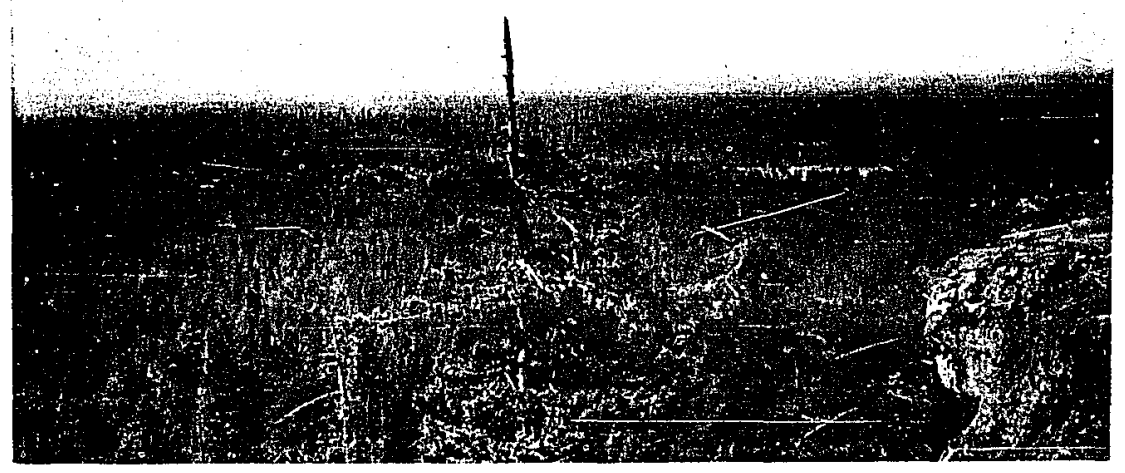

Figure 3. Coastal lowland and mountain front as seen from an isolated hill near Parksville. Mount Arrowsmith at left, Cameron Valley in centre, and Horne Lake Valley right of centre.

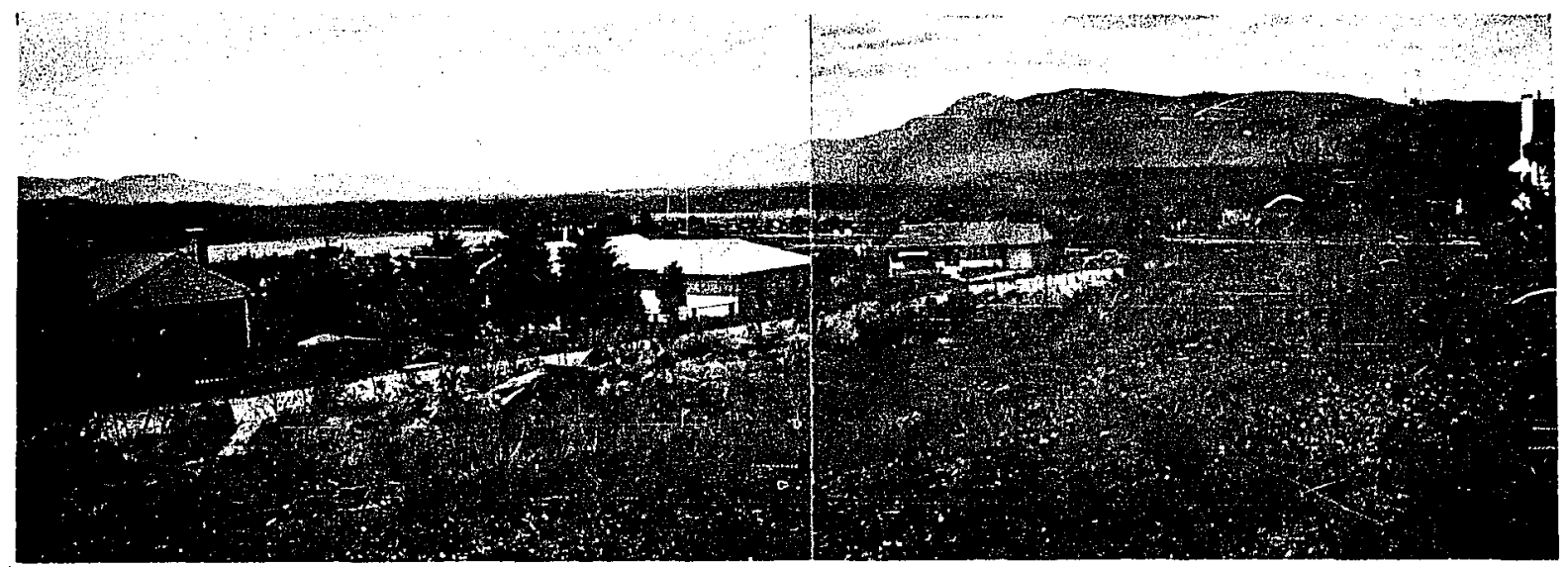

Figure 4. View northwest up Alberni Valley from Port Alberni. Alberni Inlet left of centre. 


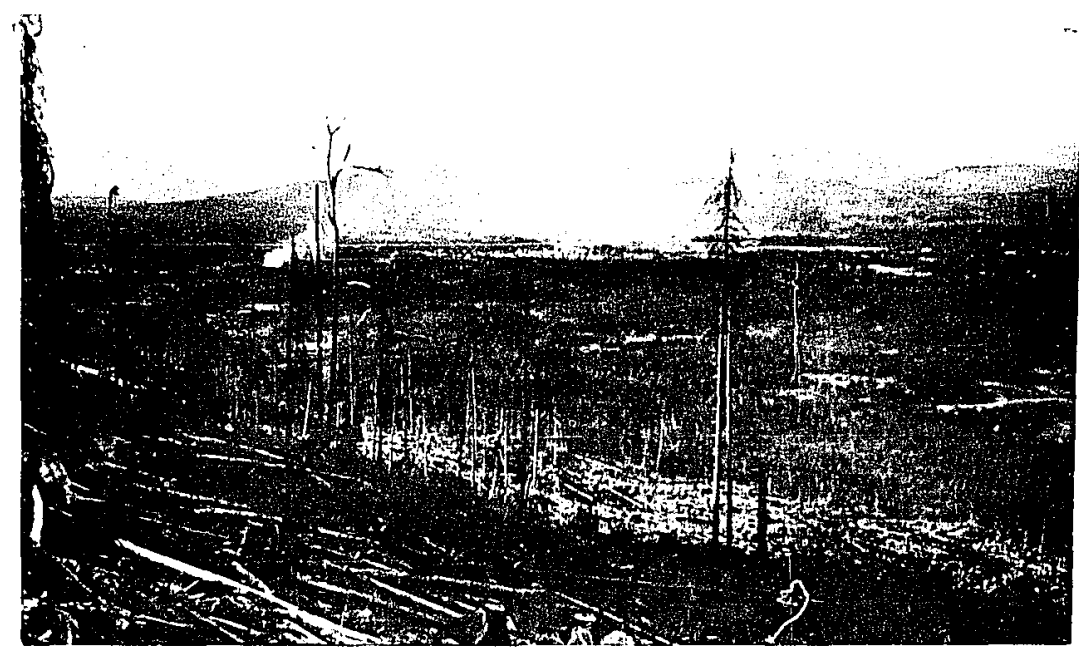

Figure 5. View south across Alberni Valley from the mountainside near Bainbridge showing the rolling uplands enclosing the southern end of Alberni Valley. The head of the narrow fiord valley of Albemi Inlet is just right of centre.

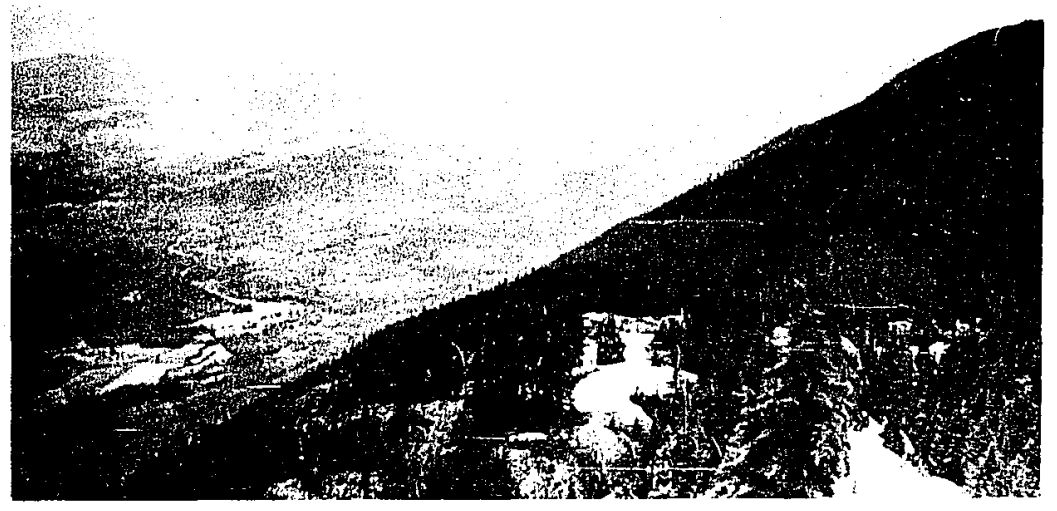

Figure 6. Looking northwest from the summit of Mount Hal along the steep scarp on the northeast side of Alberni Valley. Flat floor of Alberni Valley at lower left, low-relief ridge tops of Beaufort Range at upper right. 
end. Most of the valley bottom, characterized by gently rolling hills and depressions a few tens of feet high, is underlain by shale and sandstone of the Nanaimo group and is surfaced with unconsolidated deposits several tens of feet in thickness. The western part of the valley, on the other hand, consists of hummocky outcrops of the basement rocks separated by drift-filled depressions. The valley is bordered on the northeast by a steep and almost straight mountain face (see Figure 6) marking a fault contact between Nanaimo group sediments and the basement volcanic rocks. The southwest margin of the valley is a more gently rising mountain slope cut by westward-trending steepwalled valleys.

MOUNTAINS AND MOUNTAIN VALLETS

The mountainous sections of the map-area, for the most part, consist of broad-topped ridges separated by deep, glaciated valleys. Mountain summits are merely high points on ridge crests although, locally, encroachment of valleys and cirques into the ridge sides has carved sharp aretes and precipitous horns. Summits are mostly 3000 to 5000 feet above sea-level, although Mount Arrowsmith, standing well above the general level, reaches an altitude of 5962 feet. Northwest of the area, in the Forbidden Plateau and beyond, is a belt of higher country with many summits approaching 7000 feet above sea-level.

Valleys of the mountainous parts of the region are typically narrow, steep-walled troughs shaped by glacial erosion, although some of the smaller valleys with steep gradients have V-shaped, streamcut form. The longer valleys have gentle gradients and some of them contain closed rock basins that impound the larger lakes of the district. 
The valleys of Sproat Lake (Figure 7) and Great Central Iake are similar in form to typical fiord valleys of the nearby coasts. Most tributary valleys meet the trunk valleys almost at grade although a few tributaries bear a hanging relationship to the main valleys. The valleys on the slopes of the higher mountains characteristically head in cirques, many of which contain tarns.

Lpl ands and most ridge tops characteristically are gently sloping and rolling areas set off from the surrounding hillsides and valley walls by an abrupt change of slope that is clearly discernible in the contoured topographic maps (see Plate IA). Crests of narrow aretes exhibit longitudinal profiles closely accordant with nearby broad ridge tops, and here and there they broaden into tiny plateaus. The presence of these remnants of a low-relief upland surface throughout southern and central Vancouver Island has been noted by C. H. Clapp who reports as follows (1914, p. 19): "In the southern part of Vancouver Island it seems as if this surface before uplift was nearly a plain with only a few rounded hills composed of especially resistant rocks remaining a few hundred feet above the general level. In the central part of the island, however, the surface appears to have been one of considerable relief with larger and higher residual hills and small ranges of mountains." Within the map-area, ridge tops and intervalley uplands typically have local relief of several hundred feet, although here and there they include plateau-Iike areas with local relief of less than 200 feet. Along parts of the mountain front bordering the coastal lowland, ridge-sumit uplands grade imperceptibly into fairly gentle regular slopes, some of which pass into the lowlands without 


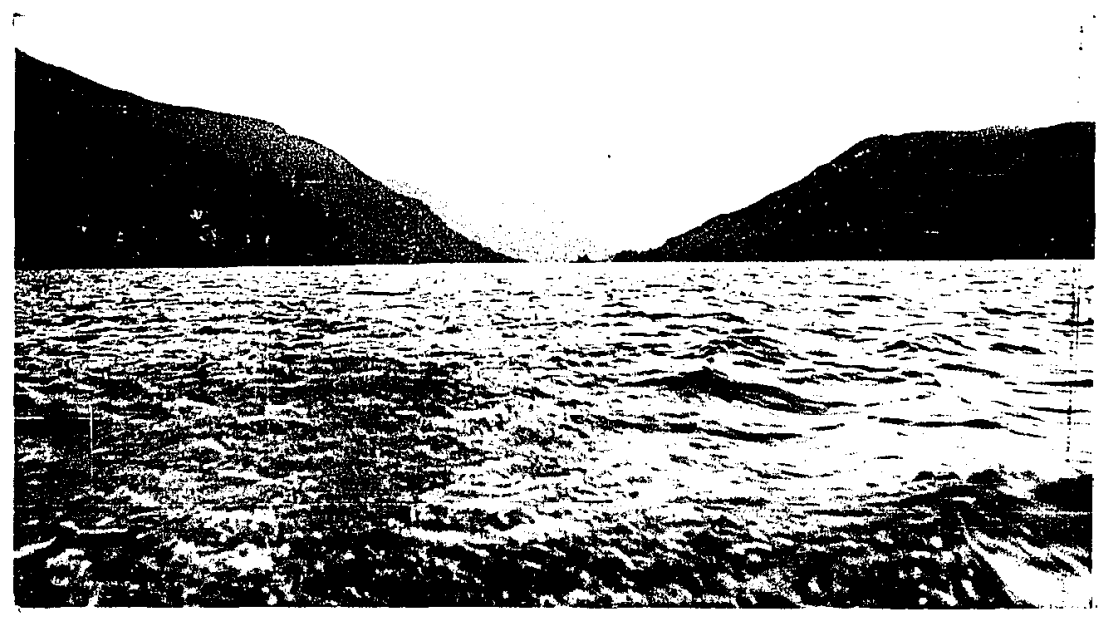

Figure 7. View westward along Sproat Iake showing the U-shaped form of the valley and the abrupt break in slope where the steep valley wall meets the upland surface. 
interruption by steep faces. These slopes contrast sharply with the steep walls of valleys cut into them and with adjoining oversteepened segments of the mountain front.

Ridge-top uplands are found at many elevations within the area. In Beaufort Range, for instance, they form the crest of much of the main summit ridge between 4500 and 5000 feet above sea-level. Southwest of Wunt Irwin, where the main ridge of the Beaufort Range drops off gradually to merge with a knobby plateau south of Horne Lake, the crest of the ridge includes about half a dozen gently sloping upland segments between 4200 and 1500 feet above sea-level. The contour maps and a series of projected profiles have provided no suggestion of distinct, separate upland levels, but rather convey the impression that the uplands and the gentle slopes are remnants of a rolling surface of considerable relief. Projected profiles across the Beaufort Range reveal a broadly rounded surface rising from the coastal plain, first rather steeply and then very gently, to culininate along the top of the steep scarp bordering Alberni Valley. Extensive fault movements have taken place along this scarp and the inclination of the upland surface may, perhaps, be the result of these movements. Possibly, the steepening of the profile inmediately southwest of the coastal lowland may reflect similar though smaller relative movements of the mountains and the Georgia depression.

\section{ORIGIN OF MOUNTAINS AND LOWLANDS}

The main elements of the physiography of the region are genetically related to the bedrock structure. Alberni Valley and the coastal lowland conform closely to basins of soft Upper Cretaceous 
sediments. Their depressed position relative to the mountains probably is partly due to rapid erosion of the basin sediments but, to a large extent, is the result of downward fault movements of these basins relative to the mountains. The valleys within the mountains consist dominantly of north-, northeast-, and northwest- trending segments which parallel the regional fault and fracture pattern (Peacock, 1935) and for the most part appear to have resulted from differential erosion along fault and fracture zones.

Mevation of the rolling upland surface of the mountainous parts of the area to approximately its present position relative to the lowlands, and dissection of this surface by narrow valleys, appear to have taken place before deposition of any of the surficial deposits and before erosion of any elements of the present glacially sculptured landscape. All the surficial materials and glacial features so far recognized in the area are believed to have formed since mid-PIeistocene time. Therefore, the elevation and dissection of the rolling upland surface may possibly have taken place, as rerently as the middle part of the Pleistocene epoch, although it may well have occurred earlier. The youngest coastal-plain sediments along the southwest side of Vancouver Island are Miocene in age, and it has been suggested (Clapp, 1917, p. 17; Hoadley, 1953, p. 45) that uplift of these sediments and of the old erosion surface farther inland took place during Pliocene time.

GLACIAL SCULPTURE

Glacial ice has overridden the entire area except perhaps the summit ridge of Mbunt Arrowsmith. Narrow valleys have been exten- 
sively remodeled by glacial erosion, as is evident in their trough shape, in the closed rock basins on their floors, and in the cirques at their heads. The remarkable steepness of many hillsides (e.g• the front of the mountains bordering the Georgia depression) also appears to be largely the result of glacial erosion. On the other hand, the topographic form of hill, ridge, and mountain tops and of relatively flat areas appears to have been but little modified by overriding glacial ice, even though the smoothed and rounded form of outcrops in such places provides evidence of universal small-scale glacial erosion. The area has undergone at least two separate glaciations and during each glaciation a complex succession of changes in ice-movement direction accompanied changes in ice thickness and source. Hence, glacial sculpture in most parts of the area must be the result of ice movements in more than one direction. As would be expected, the best recorded small-scale erosional features are those produced during the latest glacial movement. On the other hand, the major elements of the glacially sculptured landscape, with a few exceptions, are the result of ice movement down valleys in the same direction as the natural drainage, even where movement in this direction has been succeeded by movements in radically different directions.

The most striking glacial-erosional features of the region are the cirques and U-shaped mountain valleys. Cirques and U-valleys heading in cirque-like basins record the former presence of local mountain glaciers. They occur on most mountain masses of the region with summits more than 4500 feet above sea-level and are rare on those with sumits below 4000 feet. Cirques within the map-area average half 
a mile in diameter and between 500 and 1000 feet in depth, but some cirque-like heads of U-valleys are $1 \frac{1}{2}$ miles across and have headwalls more than 2500 feet high. In the Beaufort Range, floors of cirques range from 3000 to 4200 feet above sea-level, and floors of cirque-like heads of the larger U-valleys such as those of Wilfred Creek and Rosewall Creek are 1500 to 2500 feet above sea-level. On the northeast side of Mount Arrowsmith, cirques with tarns range from 2600 to 4500 feet above sea-level (Figure 8) and shallow incipient cirques carrying permanent snow patches occur above 5000 feet. Two or even three cirques occur in vertical succession at the heads of some valleys. For instance, Rosewall creek heads in a cirque-like basin about a mile across with floor 1800 feet above sea-level and headwall 2500 feet high. Notching the west side of this amphitheatre is a cirque half a mile across with floor 3200 feet above sea-level, and perched on the headwall of this cirque is another, a quarter of a mile across, containing a tarn about 3700 feet above sea-level. The cirques and Uvalleys have undergone little modification since they were formed. The steep cirque and valley walls still are separated from the less-steep ridge tops by an abrupt change in slope, and, as revealed by the abundance of tarns, stream notches in the bedrock sills of the cirques are shallow.

Some of the U-shaped valleys extend through the mountains instead of heading in them. Some of these through valleys, such as Alberni Valley and the valley of Upper Qualicum River connecting Rosewall Creek Valley to Horne Lake, have tributaries heading in the mountains. Glaciation of these valleys could have been accomplished 


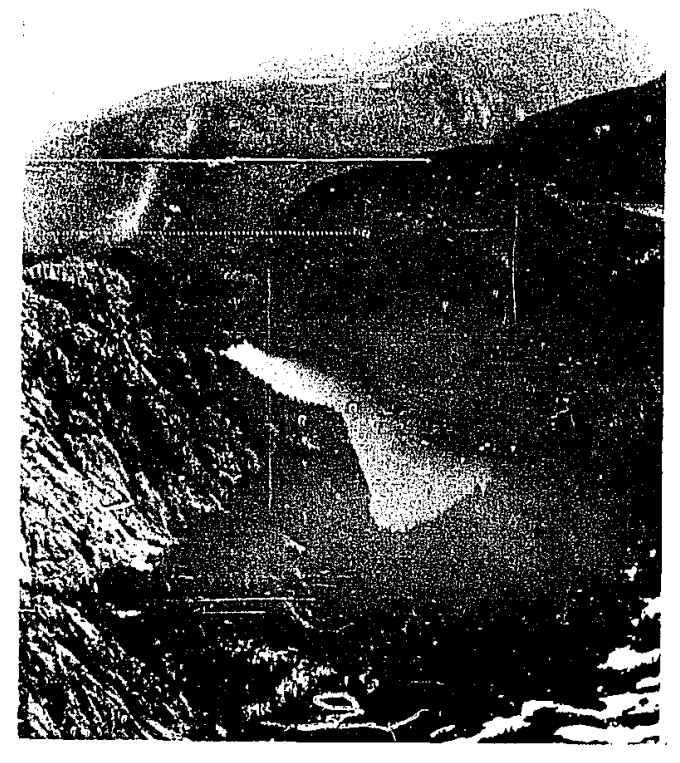

Flgure 8. Cirque with tarn, east face of Mount Arrowsmith. Englishman River Valley in beckground.

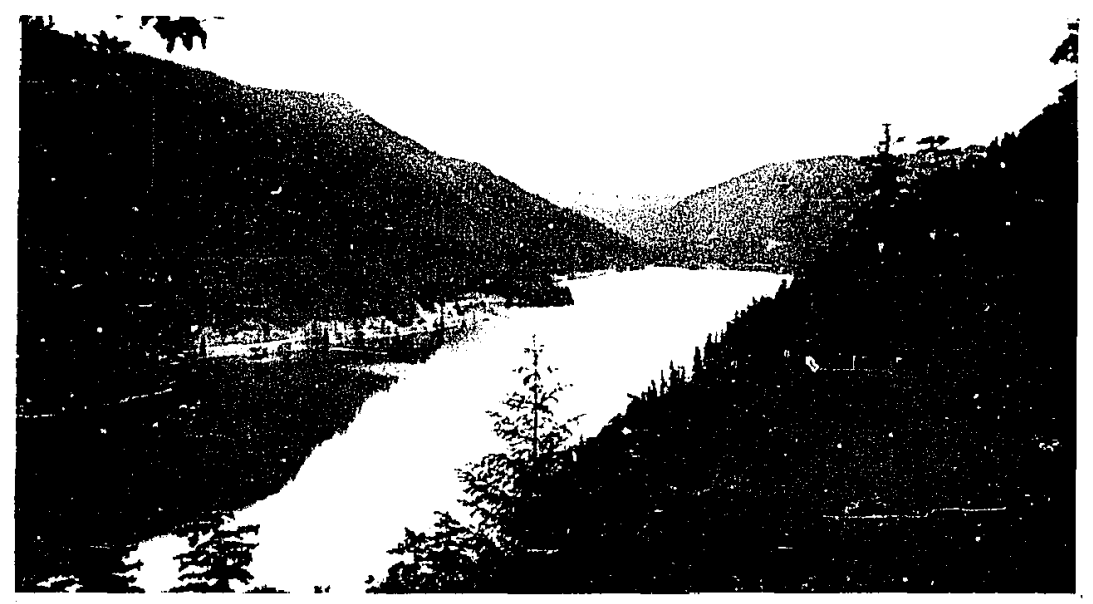

Figure 9. View westward through Cameron Valley towards Alberni Valley. 
by local mountain glaciers emanating from the tributaries. Some of the through valleys of the Beaufort Range, on the other hand, have no tributaries from which mountain glaciers could have spread, and glaciation of these valleys can only have been accomplished by ice moving into or through the range from the adjoining low country. The steepwalled valley containing the rockcut basin of Cameron Ialce (see Figure 9) is of this type. Horne Lake Valley is part of a broad depression crossing the Beaufort Range and appears to owe its glaciated form to movement of ice through the range by way of this depression. A mach smaller through valley forms a prominent U-shaped notch in the steep north wall of Cameron Valley at the west end of Cameron Lake. From the notch, the valley slopes downward to the north away from Cameron Lake and towards the coastal lowland. This appears to be a reverse hanging valley eroded into U-form by south-moving ice squeezing between Mount Wesley and Mount Horne to merge with ice in Cameron Valley. 
GHAPTER 3

\section{STRETIGRAPHY AND NOMENCLATURE OF SURFICIAL DEPOSITS}

\section{"STANDARD" SUCCESSION}

The surficial deposits of the coastal lowland include a distinctive succession of two groups of glacial materials separated by non-glacial sediments and overlain by marine and fluvial deposits. Mis "standard" succession is used in this report as the basis for stratigraphic subdivisjon of the surficial deposits throughout the maparea (see Figure 10). The "standard" succession is based upon the following sequence of deposits, whose nembers are widely recognizable in the sea cliffs and river banks along the coast.

8. Marine and fluvial gravel, sand, silt, and clay, very variable.

7. Till, grey and sandy.

$$
\text { (erosional unconforinjty) }
$$

6. Sand, white, horizontally stratified, current bedded.

5. Silt, fine gravel, sand, peat, and wood; distinctive orange-green colours.

4. Silty clay, contains stones and marine shells, massjve.

3. Clay and silt, laminated.

2. Till, grey, silty to sandy, contains gravel and silt interbeds.

1. Sand, silt, clay. 


\begin{tabular}{|c|c|c|c|c|c|c|c|c|c|c|c|c|}
\hline GROUP & GIACIAL & $\begin{array}{l}\text { GLACIO- } \\
\text { FLINIAL. }\end{array}$ & $\begin{array}{l}\text { GLACIO- } \\
\text { LACUSTRINF }\end{array}$ & $\begin{array}{l}\text { GLACIO. } \\
\text { MARINE }\end{array}$ & MARINF & $\begin{array}{l}\text { MARIN: } \\
\text { SHORE: }\end{array}$ & $\begin{array}{l}\text { MARINE: } \\
\text { DFLLTAIC }\end{array}$ & \begin{tabular}{|c|} 
CHANNELL- \\
Fl.OODPLANN \\
\end{tabular} & LACUST RINE & $\begin{array}{c}\text { ALLLUVIAL } \\
\text { FAN }\end{array}$ & SLOPE & $\begin{array}{l}\text { UPLAND } \\
\text { SWAMP } \\
\end{array}$ \\
\hline $\begin{array}{c}\text { SALISH } \\
\text { (deposits } \\
\text { presentily } \\
\text { being (armed) }\end{array}$ & & & & & & \begin{tabular}{|l|} 
Gravel, sand, \\
silt, clay, \\
and musk at \\
present \\
shorcline \\
\end{tabular} & \begin{tabular}{|l|} 
Crayel, sand, \\
sill, and muck \\
in deltas along \\
Cieorgia Strait \\
and Alberni \\
Inlet \\
\end{tabular} & $\begin{array}{l}\text { Gravel, sand, } \\
\text { silt, and mucci } \\
\text { along btreans }\end{array}$ & $\begin{array}{l}\text { Ciravelly shorr- } \\
\text { line de posils; } \\
\text { gravel, sand, } \\
\text { and aitt in } \\
\text { ileitas } \\
\end{array}$ & $\begin{array}{l}\text { Poorly sorled } \\
\text { gravel and } \\
\text { sill }\end{array}$ & $\begin{array}{c}\text { Collusium, } \\
\text { talus, } \\
\text { landslide } \\
\text { rutble }\end{array}$ & $\begin{array}{l}\text { Peat } \\
\text { and }\end{array}$ \\
\hline $\begin{array}{l}\text { CAPILANO } \\
\text { (non-glacial } \\
\text { depesits that are } \\
\text { no longer being } \\
\quad \text { formed) }\end{array}$ & & & & & $\begin{array}{l}\text { Clay, sill, sand, } \\
\text { and poorly so:- } \\
\text { ted till-like } \\
\text { mixtures; con- } \\
\text { tain marine } \\
\text { shells, rare } \\
\text { driftwood and } \\
\text { leaves }\end{array}$ & $\begin{array}{l}\text { Stony wave- } \\
\text { vashed lag } \\
\text { reneer, gravel, } \\
\text { sand, silt, } \\
\text { clay, till-like } \\
\text { inaterials; cun- } \\
\text { tain marine } \\
\text { shells, rare } \\
\text { driftwood and } \\
\text { leaves } \\
\end{array}$ & $\begin{array}{l}\text { Gravel,saml, } \\
\text { and minor } \\
\text { silt; contain } \\
\text { rare tharine } \\
\text { shelly, drift } \\
\text { wood t }\end{array}$ & $\begin{array}{l}\text { Cravel, minor } \\
\text { sand and sil: } \\
\text { bentath } \\
\text { terraces }\end{array}$ & $\begin{array}{l}\text { Gravel and } \\
\text { sand terrace } \\
\text { deposite; sill } \\
\text { and clay; (not } \\
\text { clearly distin- } \\
\text { guished Irom } \\
\text { glacio-lacus- } \\
\text { Irine deposits) }\end{array}$ & \begin{tabular}{|l|} 
Porrly sorted \\
gravel and \\
sillt in fang and \\
depression \\
Cillings; stony \\
"pedilizent" \\
lag veneer
\end{tabular} & $\begin{array}{l}\text { land- } \\
\text { sidide } \\
\text { rubble }\end{array}$ & \\
\hline \multirow{3}{*}{$\begin{array}{l}\text { VASHON } \\
\text { Ideposits of the } \\
\text { last regional } \\
\text { glaciation) }\end{array}$} & & \multirow{2}{*}{\begin{tabular}{|l} 
Gravel, sand, \\
and silt form- \\
ing ice-con- \\
lact deposits \\
\end{tabular}} & Sand and & \multirow{2}{*}{\begin{tabular}{|l|} 
Stony clay, \\
till-like \\
mate rials; \\
contain \\
marine shells \\
\end{tabular}} & & & & & & & \multirow{2}{*}{\begin{tabular}{|l|} 
Landslide \\
rubble in \\
part mixed \\
with glacio- \\
illuvial gravel \\
\end{tabular}} & \\
\hline & $\begin{array}{l}\text { Grey till, andy } \\
\text { to clayey } \\
\text { texture }\end{array}$ & & $\begin{array}{l}\text { gravel;lamina- } \\
\text { ted ailt and } \\
\text { clay }\end{array}$ & & & & & & & & & \\
\hline & & & & & EROSION SUR & RFACE Irelief & if of several hund & idred feet) & & & & \\
\hline \multirow[t]{2}{*}{$\left|\begin{array}{c}\text { QUADRA } \\
\text { (intertill, non- } \\
\text { glacial deposits }\end{array}\right|$} & & & & & & & \multicolumn{2}{|c|}{$\begin{array}{l}\text { Horizontally stratified crosg- } \\
\text { bedded sand and minor silt and } \\
\text { gravel; local peat, peaty "soil" } \\
\text { and leal layers }\end{array}$} & & & & \\
\hline & & & & & $\begin{array}{l}\text { Silt containing } \\
\text { marine ahells }\end{array}$ & \multicolumn{3}{|c|}{$\begin{array}{l}\text { Silt, pebble gravel, sand, and cobbly lag } \\
\text { gravel; distinctive orange-green colouring; } \\
\text { contain peat, peaty "soil", driftwood }\end{array}$} & & & & \\
\hline \multirow{3}{*}{$\begin{array}{l}\text { DASHWOOD } \\
\text { (de positi } \\
\text { related to } \\
\text { glaciation) }\end{array}$} & & & & $\begin{array}{l}\text { Stony clay, till- } \\
\text { jike materials; } \\
\text { contain marine } \\
\text { shells }\end{array}$ & & & & & & & & \\
\hline & & & $\begin{array}{l}\text { Laminated clay } \\
\text { and silt }\end{array}$ & & & & & & & & & \\
\hline & $\begin{array}{l}\text { Grey till, silty } \\
\text { to sandy texture, } \\
\text { contains silt and } \\
\text { gravel lenges }\end{array}$ & & & & & & & & & & & \\
\hline $\begin{array}{l}\text { (sub-Dashwood } \\
\text { (non-glacial } \\
\text { deposits) }\end{array}$ & & & & & & & & Sand, silt, anci cl & & & & \\
\hline
\end{tabular}

Figure 10. Stratigraphic and environmental chart 
The lovernost unit of this seciuence has been iefen in on ly two places but cliffs exposing all the other units have been found in the six pleces shorn on Fijere 1.1. Ihe wecession has been mepped for 3 miles along the busy Dashrood sea cliff (croasmsection Plate IA). and has been traced equivelent distances along the valley of Qualicun River and along Komas Bluff or Deninan Island (see Figure 59). The peat-bearing beds (unit 5), so far as known, are not duplicated wi thin the region in any other stratigraphic position, and cau therefore be correlated froin place to place with some assurance. Unfortunately the two tills cannot be differentiated in moist places on the basjs of lithology; the sjlt and stony clay overlying the loter till are duplicated by jdentical deposits overlying the upper till; and the white sand beneath the upper till, although differing from the sand beneath the lower till, has been locelly redeposi ted as post-glacial marine and deltajc accunulations (unit 8) very sinilar to the parent deposit. Nonetheless, certain combinations of two or nore of these units (for instance till overlyjng wite, horizontal sand) do appear to be stratisraphically distinctive. Such distinctive conbingtions of deposjts are exposed in many places, and, togethex wi th the fewer exposures of the peat-bearing beds, have providea a basis for correlation of the "standard" succession throughout much of the coastal lowland. Deposits may possjbly be missing from the above sequence at the erosional unconformi ty between the upper till (unit 7) and the underlying sand. Indeed, a series of deposjts consjsting of till, gravel, sand, silt, and clay, and lyjng between two erosion surfeces, has been assigned to this stratigraphic position in the Lower Fraser Valley (see end of this 


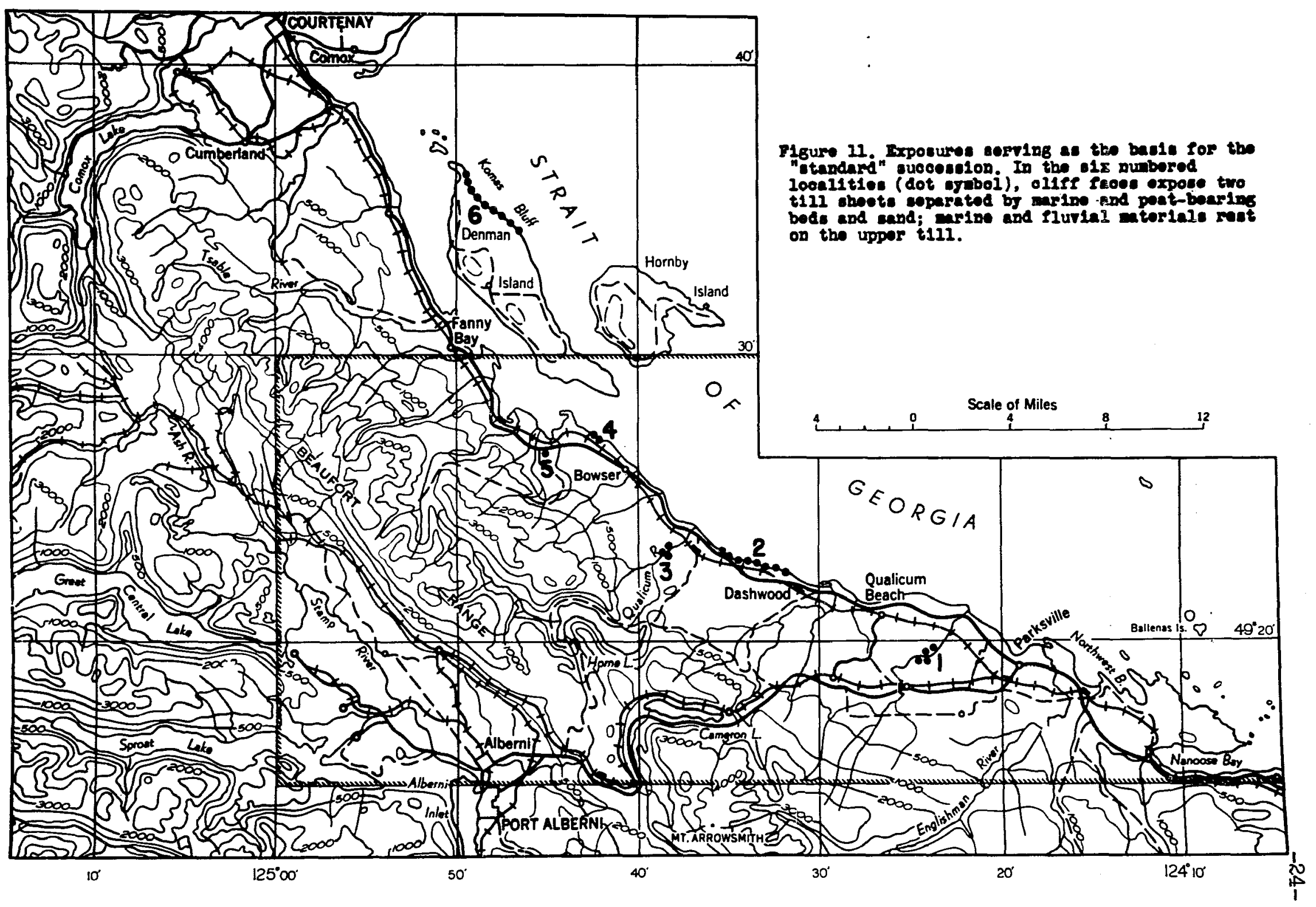


chapter). Ilonetheless, remnants of such deposits have not been found on Vancouver Island and the writer has tentatively assumed that the above. "stendard" succession approxina.tes the naturel sequence of deposits in the map-aree and provides a valid basis for reconstruction of a local sequence of events.

\section{HISTORY OF NONFNCLA TUFE}

Seruences of deposits very similar to the "standard" succession outlined above are exposed in inany places throughout the Georgia depression and the Puget lowland. G.W. Dawson, rorking in the northern fart of the Georgia depression northwest of the area under present consideration seems to have been the first to record the more-than-local distribution of such deposits and to speculate on their significance. He noted a juccession of two tills jeparated by stratifjed silts and sands and has suggested that it recras an early major glacjation and a later minor one separated by a period of glacial retreat (Dawson, 1887, p. 105). During the 1890's, Bajley Willis made the first comprehensive study of Pleistocene features of the Puget loriland, at Tacoma. He found rusty gravel and stratified sand underlain by till and clay, and overlain with erosional unconformity by an upper sheet of till. He applied the name Vashon to the till above the unconformi ty "distributed by the northern glacier curing the last glacial epoch" (Willss, 1898, p. 150) and included in the Vashon glacial epoch all correlatjve glacial features. Believing the lower tjll and clay to belong to a djstinct, earljer glaciation, he assjgned them to a separate glacjal epoch that he called "Admiralty". He described the intertill strata as outwash and glacial-lake beds 
and assigned both these deposits and the succeeding erosional interval (represented by the unconformi ty between them and the Vashon till) to the Puyallup interglacial epoch. During comprehensive Pleistocene investigations in the Puget Sound region, Bretz (1913) found a simjlar succession of deposits throughout much of the Puget lowland. He encountered numerous exposures of peaty beds within the intertjll sedijments as well as $\mathbf{i}$ solated mammoth teeth, elk homs, whale (?) vertebrae, and marine shells. Willis apparently had believed that the present patchy distribution of the intertill sediments approximates their orjginal constructional form and thet they accumulated betreen remnant tongues of fdmiral ty ice occupying the present sites of the Puget troughs, but Bretz argues convincingly that the sediments are the eroded remnants of "a great plain of terrestrial deposits, containing a fer marine beds in the lower portion" that "js conceived to have been aggraded in front of the waning Admiralty glacier as it Wh tharew to the north" (Bretz, 1.913, f. 15). He therefore termed the intertill beds the Admiralty sediments, placing them in the Admiralty glacial epoch and restricting the Puyallup interglacjal epoch to the period of erosion represented by the unconformity that truncates them. During extensive geological studjes in southern Vancouver Islend (1908 to 1913), C.H. Clapp noted glacial drift overlying sand, gravel, and clay in meny places and reported the presence of two sheets of till separated by marine clay in a very few exposures at Victoria (1913, Figure 5). He correlated these deposits wi th the similar deposite described by Willis at Tacoma and classified them, along wi th the overlying outwash-delta deposits and alluvium, as 
tabulated below (Clapp, 1913, p. 108).

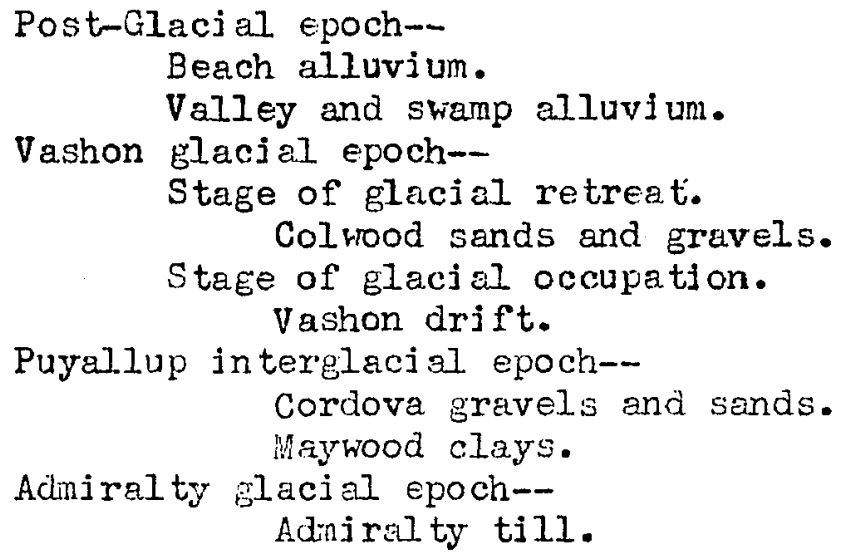

Clapp noted the presence of raj sed post-glacial marine deposits but described them as being "thin and of sinall extent" (1917, p. 253) and assigned the extensive marine clays of the region (botis buried and veneering the surface) to the Puygllup interglacial epoch. Arnold and Honnibal (1913) and Newcombe (1914), on the other hand, reported abundant post-glacial rajsed marine "beach" deposjts on southern Vancouver Isiand, which they designated as the Saanjch formation. They included in this category some of the deposits that Clapp assigned to the Puyallup interglacial epoch.

Geological investigations in the country around Vancouver by E.M.J. Burwash and by W.A. Johnston revealed a succession of deposits similar to that on Vancouver Island and in the Puget Sound region. Burwash (1918, p. 81) subdivides the deposits as follons: 
5. Outwash and delta sands and gravels.

4. Vashon till.

Unconfornity (Puyrllup interglacial period)

3. Admiralty clays and sands.

2. Admi ral ty "till.

1. Nicornekl (Njcomekl?) sand and silt.

Ljke Bretz, Burwash classjijed the intertill sediments as outwash associated with the retreat of the Admiralty ice and reduced the succeeding interglacial interval to one of uplift and erosion. Johnston, on the other hand, included in the interglacial a succession of peat-bearing beds, which he called the Point Grey fornation, lying wi thin the Admiralty sediments at Point Grey. He therefore classffied only the lowernost of tine sub-tjll (Adniralty) sedinents in this locallty, beneath the Point Grey fornation, as outwash of the. Admiralty ice and considered the uppernost beds, above the roint Grey formation, to be advance outrash of the succeeding Vashon glaciation. Associated wi th the upper (Vashon) till sheet, Johnston found stony clay contajning marine shells at various places up to 350 feet above sea-level. He noted that much of this stony clay "closely resembles tjll but is faintly stratified and was probably deposjted below sealevel, ej ther from beneath the jce -- which was partily buoyed up -- or from floating $j \mathrm{ce}, "$ and he related these shell-bearing deposits to a minor glacial advance "which occurred late in the Plejstocene, and was in reality associated with the final retreat of the ice from the region" (Johnston, 1923, p. 50). Johnston also reported the presence of the clays overlying the shell-bearing material up to 300 feet above sea-level and delta and beach deposits up to 650 feet, and noted that "the till on the uplands is, in most places, covered by a small thickness of sands 
and gravels which are, apparently, due to wave wash" (Johnston, 1923, p. 47-48): he described all these materials as post-glacial marine deposits even though he found no marine shells in them. Johnston did not apply stratigraphic or age names to ej ther the stony clays or to the post-glocjel marine deposits.

During recent years, much detailed study of the plejstocene deposits of the Puget lowland has been done by J. Hoover Mackin and his students at the University of leshington, and by geologists of the Unjted States Geological Survey engaged in ground-water and engineering work. The few publjations dealing with this work reveal stratigraphic complications not accounted for in the jimple: schemes of Willis and Bretz. For instance, an exposed section at Possession Point including three till sheets separated by two successions of stratified sedjments has been described by Mackin (Fansen and Mackin, 1949), and a similar stratigraphic succession, 11lustrated djagrammetjcally in Figure 12, bas been reported at Seattle (Mackin, Mullineaux, and Stark, 1950). Most of the Puget Sound geologists seem to have discarded the "epoch" time units of Willis and Bretz and merely refer the depusits to nore or less local formational units as, for example, in the Seattle sectjon reproduced in Figure 12. Willis' name "Vashon" is still used for the uppermost till at Seattle and probably elsewhere, but the terms "Admiralty" and "Puyallup" apparently ere no longer being used in any formal serise because of uncerteinty regarding the jdentity of the strata to which they should be applied.

In the current studjes of surficial stratigraphy of the Lower Fraser Valley by J.F. Armstrong and associates and of Vancouver 


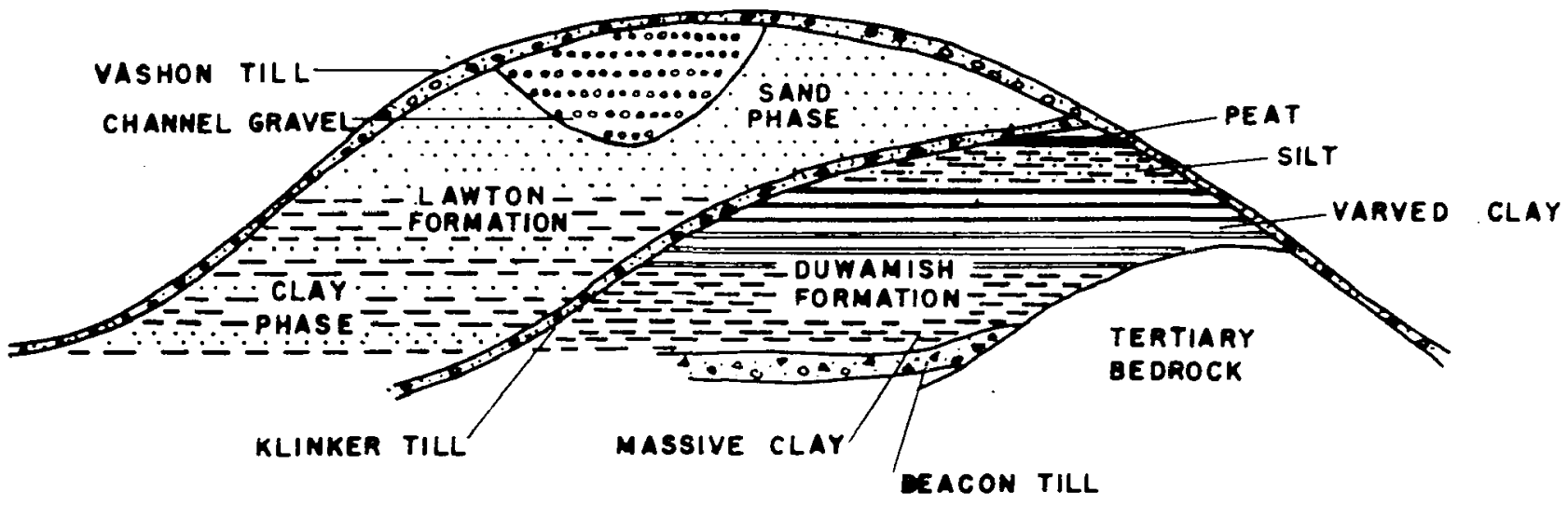

Figure 12. Dlagramatio oross-seotion showing possible complexity of a Soattle hill (after Maokin, Mullineaux, and stark, 1950) 
Island by the writer, a great many formational units have been distinguished, particularly in the marine, fluvial, and glaciofluvial. deposits that veneer much of the lowland surface. Formal formational names have been applied to mary of these units in the Lower Fraser Valley (see Armstrong and Brown, 1953, Table of Pleistocene and Recent deposits). The "epoch" time divisions that were introduced at Vancouver by Burwash and on Vancouver Island by Clapp have been discarded in keeping with the current feeling against use of such local time terms and following the lead of geologists working in the Puget sound region where these terms were originally applied. However, in the absence of major units or groupings to replace the "epochs" the overall relatively simple succession of events becomes obscured in the bewildering array of formational units, many of which are merely stratigraphically equivalent deposits formed in different envirorments. Therefore, in 1952, the writer suggested to Dr. J. I. Armstrong that each series of related glacial deposits, each series of non-glacial deposits, and so on be designated as a "group". Each group would then consist of lithologic units, either formally named or informally referred to by the group name, that either are facies equivalents or fit together as a distinctive part of the stratigraphic succession. This proposal was accepted and has been used by Armstrong and Brown in their report on ground-water resources of Surrey Municipality (1953). The groups used in that report and those here applied to the Horne Lake and Parksville map-areas are listed in Figure 13. The latter are based on the "standard" succession outlined at the beginning of this chapter, and the numbers following the description of each group 


\begin{tabular}{|c|c|c|c|}
\hline \multirow{2}{*}{\multicolumn{2}{|c|}{ HORNE IAKE AND PARKSVILLE }} & \multicolumn{2}{|c|}{ LOWER FRASER VALLEY } \\
\hline & & \multicolumn{2}{|c|}{ (Armstrong and Brown, 1953) } \\
\hline Group & Definition & Group & Definition \\
\hline Salish & $\begin{array}{l}\text { Deposits that are } \\
\text { presently being } \\
\text { formed }(8) \text {. }\end{array}$ & Selish & $\begin{array}{l}\text { Post-glacial deposjts } \\
\text { still being formed. }\end{array}$ \\
\hline Capilano & $\begin{array}{l}\text { Non-glaci al deposits } \\
\text { that are no longer } \\
\text { being formed ( } 8) \text {. }\end{array}$ & Capilano & $\begin{array}{l}\text { Post-glacial deposits } \\
\text { no longer being } \\
\text { forned. }\end{array}$ \\
\hline Vashon & $\begin{array}{l}\text { Deposits of the last } \\
\text { regional glaciation } \\
\text { (7). }\end{array}$ & Vashon & $\begin{array}{l}\text { Deposits of last } \\
\text { glaciation of ice } \\
\text { sheet proportions. }\end{array}$ \\
\hline \multirow{3}{*}{ Fros } & \multirow{3}{*}{ jon interval } & Erosjon & interval \\
\hline & & Semi amu & $\begin{array}{l}\text { Deposits related to } \\
\text { glaciation, missing } \\
\text { in much of area. }\end{array}$ \\
\hline & & Erosion & interval \\
\hline Quedre & $\begin{array}{l}\text { Intertill non- } \\
\text { glacj } a l \text { sediments } \\
(5,6) \text {. }\end{array}$ & Quadra & Intertill sediments \\
\hline Dashwood & $\begin{array}{l}\text { Deposits related to } \\
\text { glaciation } \\
(2,3,4) \text {. }\end{array}$ & Seymour & $\begin{array}{l}\text { Deposits related to } \\
\text { glaciation. }\end{array}$ \\
\hline $\begin{array}{l}\text { ( sub- } \\
\text { Dashwoo }\end{array}$ & $\begin{array}{c}\text { Non-glacial deposits } \\
\text { (1). }\end{array}$ & & \\
\hline
\end{tabular}

Figure 13. Names and definitions of "group" units used in this report compared to those being used in the Lower Fraser Valley. Numbers following group definitions refer to corresponding units of the normal sequence of deposits in the Horne lake and Parksville map-areas, as listed on the first page of this chapter. 
refer to the corresponding units of the normal sequence of deposits in the "standard" succession. Because of the presence of the Semiamu group in the Lower Fraser Valley succession, the groups beneath the Vashon group used by Armstrong and Brown differ somewhat from those that are used in this report, although the Dashwood group may well be equivalent to the Seymour, and the Quadra group as used in this report can be logically correlated with at least the type Quadra group of Armstrong and Brown, at Point Grey. 


\section{CHAPTER 4}

\section{SUB-DASHWOOD DEPOSITS}

NATURE OF DEPOSITS

Sand, silt, and some clay are exposed beneath till of the Dashwood group on the sea cliff at Dashwood and at Black Point (localities 2 and 4, Figure 11). In the Dashwood exposures, sandy beds have been found under the lower till in seven measured sections in a one-mile segment of the sea cllff, as shown in the cross-section (Plate IA). Up to 40 feet of these beds are exposed and a minimum thickness of 70 feet (down to tide line) was inferred at exposure 20 (Plate IA), from auger borings through slumped material below the exposed face. These deposits at Dashwood consist of medium- to coarsegrained sand $d^{2}$ interbedded with a few thin strata of pea gravel and of laminated silt and sandy silt. A typical sample of sand, from exposure 20 , has a median grain diameter of $0.28 \mathrm{~mm}$. and sorting coefficient of 1.37. The strata are horizontal, but, in several of the exposed sections, a few beds within the otherwise uniform and undisturbed succession are complexly folded and ruptured.

At Black Point, between Bowser and Deep Bay, a recent landslide scar a few hundred feet long on the otherwise bushy sea cliff exposes up to 55 feet of medium-grained grey sand intercalated with finely laminated grey silt and clay. At the base of the west end of the exposure is a 12-foot section of cross-bedded sand wi thout

Sand, silt, clay, etc. as used in the report are defined in terms of the Wentworth grade scale. 
silt interbeds. The strate dip very gently to the east or southeast and some of the beds in the upper part of the succesion are locally contorted. The sandy strata in this exposure are very similar in appearance to the sub-Dashwood materials at Dashwood.

The base of these depositz has not been seen ei ther at Deshwood or at Black Point and, in the absence of nearby bedrock outcrops in both localj ties, unconsoliciated deposits of considerable thickness probably lje beneath those that are exposed. The Dashwood cross-section (Plate IA) reveals broad hills and hollows wi th reljef of several tens of feet along the contact between these sandy strata and the overlying till of the Dashwood group. These hills and hollows probably form an erosional topography developed upon the sand surface prior to deposition of the Dashwood till. Alternatively, they may have resulted from differential compaction of unexposed underlying materials, and, in view of the sub-parralel form of the three succeding contacts in this cross-section, such deformation could have taken place after deposition of the silt-peat unit of the ouadra group. However, this mode of origin seems unljkely because of the magnitude of the differential movements involved 100 feet?), and because of the absence of disturbed structures in all but the sub-Dashwood materjels. The exposed sub-Dashwood materials differ sufficiently from the much more widespread sands of the Quadra group that lithological distinction would probably be possible where their stratigraphic position is not otherrise evident. The sub-Dashwood sands are a little coarser than those of the Guadra group and appear to be not as well sorted. The sub-Dashwood deposjts also are darker in colour than the 
Quadra sands because of their higher content of aark rock and mineral grains. Silt and clay interbeds are more abundant in the sub-Dashwood sands than in the cuadra, end the locel al sturbed stratification of the sub-Dashwood beds is not duplicated in the Quadra sands.

\section{ORIGIN, EXTFNT, AND CORPEIBTION}

The sub-Dashwood sands and silts possess the characteristfes of floodplatn and lecustrine deposits, but whether they are glacial outwash or whether they were formed during an interstadial or interglacial interval is not knowm.

The deposits described above axe the only materials exposed In the area that are known to lie beneath the Dashwood group. However, a felrly extensive distribution of such deposits in the coastal low land is possible in viek of the prevailing lack of bedrock outcrops beneath or edjacent to the other exposures of the Dashwood group and many exposures of the lower part of the Quadre group.

Deposits equivalent to these sub-Dashwood materiels must be present In many places in the thick unconsolidated deposits of the Georgia depression, but exposures of such inaterials, beneath tro distinct groups of glacial deposits, are rare. An exposure of this sort, possiblj correlative with the sub-Dashwood sands of the Horne Lake area, forms the base of a sea cliff about 70 miles southeast of the area at Gowichan Head on Saanich Peninsula. Here, a 20-foot bed of stony glaciomarine(?) clay, which probably correlates wi th the Dashwood group, is underlain by lenses of sand and fine pebble gravel and 60 feet of horizontally stratified grey silt. $A \log$ found in one of the sand lenses beneath the stany clay is reported by Dr. V.C. Brink of 
the Agronomy Department of the University of British Columbia (oral communication) to be the trunk of a deciduous tree, possibly an oak or maple. Sands and silts occupying a stratigraphic position similar to that of the sub-Dashwood deposits ( 1.0 . beneath two tflls separated by stratified sediments) occur at the base of a sea cliff at Oceun Park in the Lower Fraser Valley. Burwash (1918) called these deposits the Nicomekl (Nicomekl?) sands and gilts and placed them beneath the Admiralty t1ll, but Armstrong and Brown (1953), who assign the overlying till and stratified sediments to the Semiamu group (see Figure 13), have correlated the Nicomekl beds wi th the Quadra group. 
CHAPTER 5

\section{DASHWOOD GROUP}

The name Dashwood group is applied by the writer to "burjed" glacial deposits that are found within the coastal part of the map-area. They have been recognized in cliff sections in the six localities marked in Figure 11. The type section is the sea cliff at Dashwood (cross-section, PIate IA), where deposits assigned to the group have been traced for about 3 miles and where their full succession, between sub-Dashwood sands and the peat-bering beds of the succeeding cuadra group, has been traced for one mile.

The Dashwood group at Dashwood and elsewhere consists of till grading uprard through laminated clay and silt into massive silty, stony clay containing marine shells. The laminated beds are beljeved to be glacjolecustrine and the stony clay glaciomarine. The materjals comprising the Dashwood deposits are not li thologically distinct and the succession within the group is duplicated by Vashon deposits. Thus, recognition of the Dashwood group has been possible only where the position of the deposits in the "standard" succession is known; that is, where they lie beneath the peaty beds and/or distinctive sands of the cuadra group. Till and stony clay whose position is not so distingui shable have been arbj trarily placed in the such more widely exposed Vashon group.

TILL OF THE DASHWOOD GROUP

Materials and Field Relations

The tills assigned to the Dashwood group are grey and unoxidized unsorted mixtures of boulder- to clay-size particles. They 
are solid enough to stand in vertjcal faces but crumble when soaked in water. Most contain enough carbonate to effervesce freel $y$ with dilute hydrochloric acid. Dashwood tills at French Creek and Chef Creek (localities 1 and 5, Figure 1I) are gravelly sandy loams. A typical sample from French Creek (sample 53-16, Flgure 14) contains 20 per cent of gravel and boulders and its grain-size histogrem ${ }^{3}$ reveals a large concentration of materigls in the fine sand size with mode at 0.25 min; sample 53-30 from Chef Creek contains more gravel and the mode of its grain-size histogram is at $0.5 \mathrm{~mm}$. Tills of the Dashwood group at Deshwood, Black Point, and Denman Island (localj tjes $2,4,6$, Fijgure 11) are more silty and contain feher stones; a typical sample from Dashwood sea cliff (sample 53-5, Figure 14) is a gravelly loan containing only 11 per cent of gravel and boulders, and its grain-stae histogram reveals a concentration of material in the sil.t and very fine sand sizes with mode at $0.30 \mathrm{~mm}$. Stones in the Dashwood group tills are dominantly subangular to subrounded. Pebbles in seven samples are 76 to 91 per cent volcanic, 6 to 19 per cent granitoid, and include rare sandstones, shales, quartzites, cherts, ergillites, limestones, schlsts, and vein quartz ( see Table I).

3Most of the grain-size data presented in this report are based upon a combined screen and hydrometer analysis; some represent combined screen and pipette analysis. The procedure used in pipette analysis was modified from that outlined by Krumbejn and Pettijohn (1938, p. 166-172). The hydrometer analysis was adapted from procedures outlined in the A.S.T.M. Standards, 1949, part 3, p. 1152-1162. Sodium metaphosphate was used as the djspersing agent. 

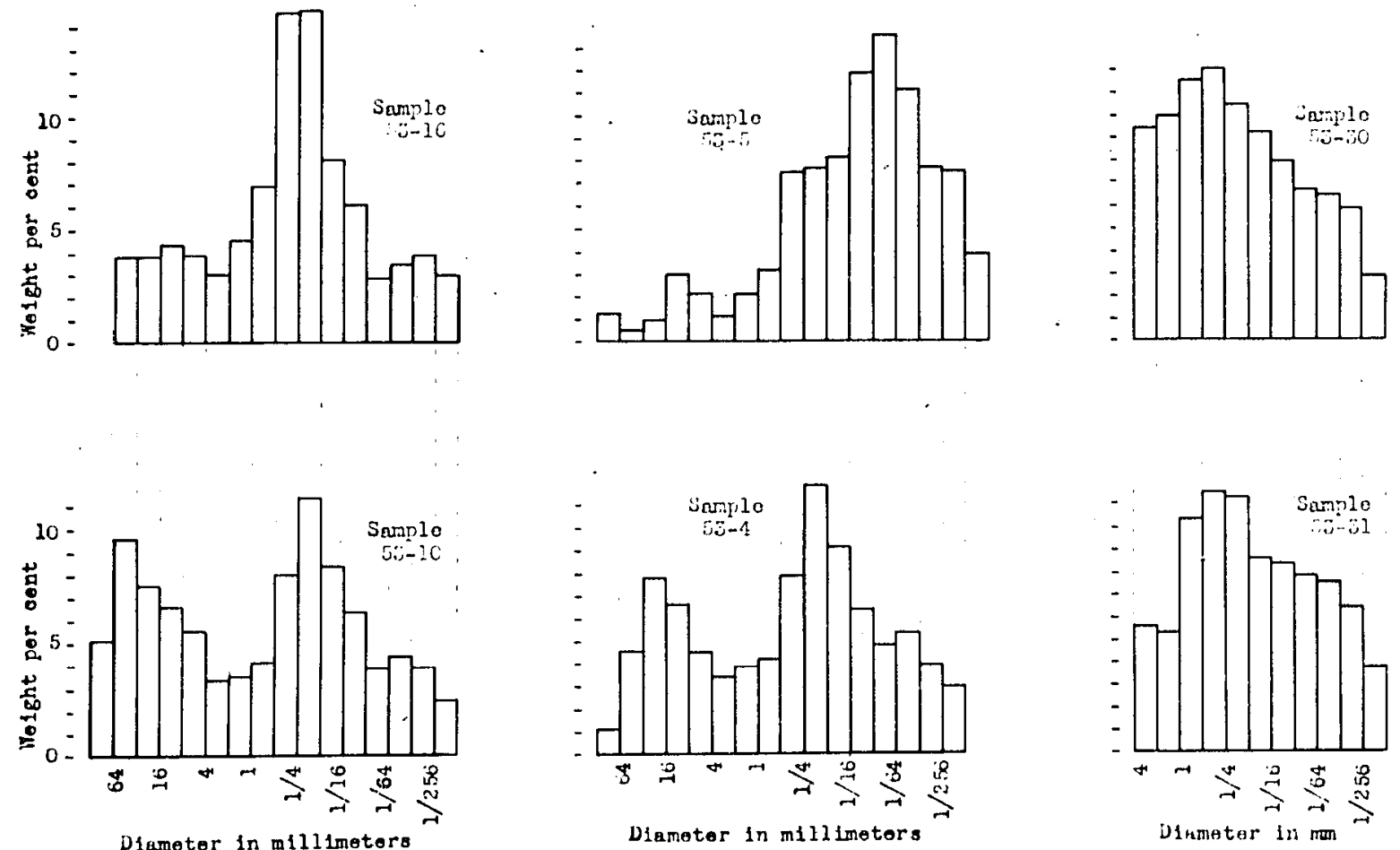

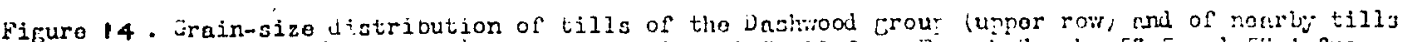
of the Vashon eroup (lowor row). Samrlos 53-16 und Dashwood, 53-30 and 53-31 from chef irooi:.
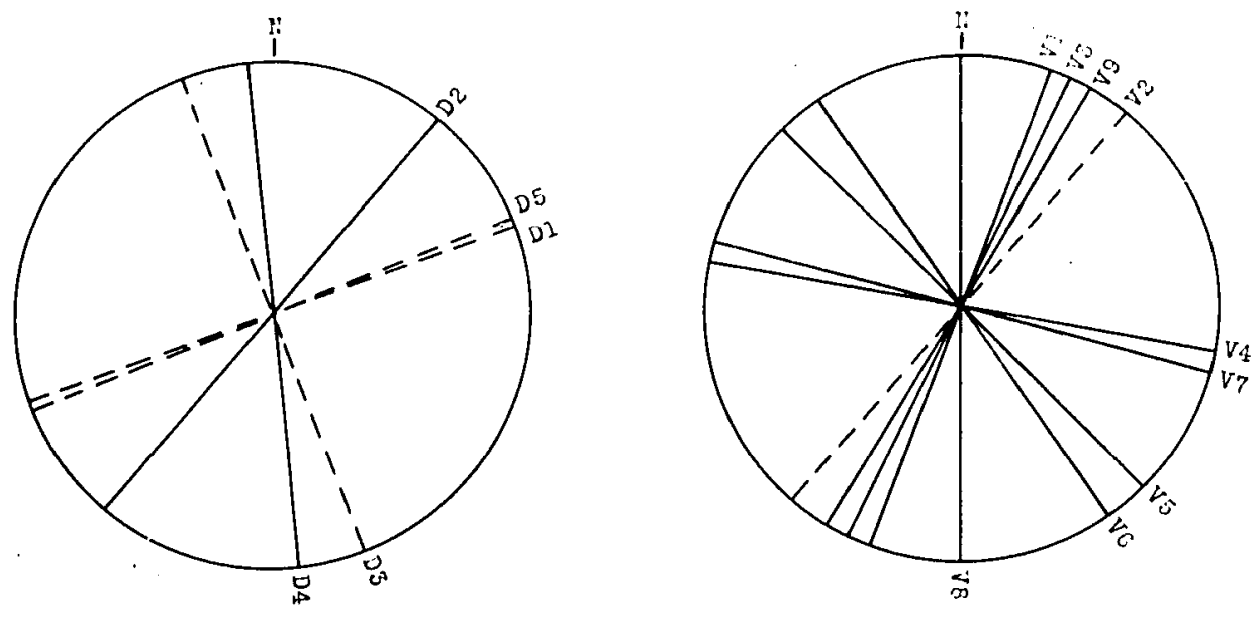

Figure 15. Fabric orientations of t1113 of the Dashwood froup (loft, and of"type" tills of the

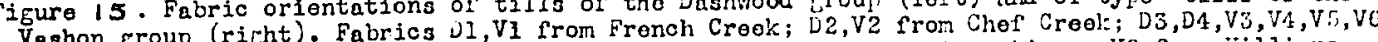
Vashon Eroup (richt 
TABLE I. PEBBLE COUNTS OF TILLS AND STONY CLAYS OF THE DASHWOOD GROUP Counts of tills of the Vashon group are included to illustrate their sjinjlarity to those of the Dashwood group.

\begin{tabular}{|c|c|c|c|c|c|}
\hline \multirow[t]{2}{*}{ I,ocetion } & \multirow{2}{*}{$\begin{array}{c}\text { Number } \\
\text { of } \\
\text { Pebbles }\end{array}$} & \multicolumn{3}{|c|}{ Percentage of rock types } & \multirow[b]{2}{*}{ (qte. $=$ therg quartzi te } \\
\hline & & Volcanic & Grani toid & $\begin{array}{c}\text { Sandstone } \\
\text { shale }\end{array}$ & \\
\hline TILLS & & & & & \\
\hline $\begin{array}{l}\text { Dashwood } \\
\text { exposure } 20\end{array}$ & $\begin{array}{l}100 \\
105\end{array}$ & $\begin{array}{l}88 \\
91\end{array}$ & $\begin{array}{r}10 \\
6\end{array}$ & & $\begin{array}{l}1 \text { schist, } 1 \text { qte. } \\
1 \text { limestone, } 1 \text { ? }\end{array}$ \\
\hline $\begin{array}{l}\text { Vashon till, } \\
\text { same place }\end{array}$ & $\begin{array}{r}105 \\
97\end{array}$ & $\begin{array}{l}91 \\
93\end{array}$ & $\begin{array}{l}7 \\
6\end{array}$ & 1 ss & 1 limestone, 1 ? \\
\hline $\begin{array}{l}\text { Dashwood, } \\
\text { exposure } 12\end{array}$ & 104 & 79 & 15 & $1 \mathrm{ss}, 1 \mathrm{sh}$ & 1 chert, 1 qte. \\
\hline $\begin{array}{l}\text { Vashon til11; } \\
\text { exposure } 16\end{array}$ & $\begin{array}{l}106 \\
105\end{array}$ & $\begin{array}{l}82 \\
83\end{array}$ & $\begin{array}{l}16 \\
16\end{array}$ & $1 \mathrm{ss}$ & $\begin{array}{ll}1 & \text { Ergillis te } \\
1 & ?\end{array}$ \\
\hline French Creek & 152 & 76 & 19 & $1 \mathrm{ss}, 1 \mathrm{sh}$ & I chert, 1. qte. \\
\hline $\begin{array}{l}\text { Vashon till, } \\
\text { same place }\end{array}$ & $\begin{array}{r}96 \\
120\end{array}$ & $\begin{array}{l}82 \\
83\end{array}$ & $\begin{array}{l}15 \\
12\end{array}$ & $\begin{array}{l}2 \mathrm{ss} \\
4 \mathrm{ss}\end{array}$ & 1 quartzi te \\
\hline Black Point & 98 & 81 & 15 & & 1 qte.., 1 quartz \\
\hline $\begin{array}{l}\text { Vashon till, } \\
\text { nearby }\end{array}$ & 105 & 81 & 12 & $5 \mathrm{ss}, 2 \mathrm{sh}$ & \\
\hline Chef Creek & $\begin{array}{r}100 \\
99\end{array}$ & $\begin{array}{l}86 \\
80\end{array}$ & $\begin{array}{l}13 \\
16\end{array}$ & $\begin{array}{ll}1 & \text { ss } \\
2 & \text { ss }\end{array}$ & 1 quartal te \\
\hline $\begin{array}{l}\text { Vashon till, } \\
\text { same place }\end{array}$ & $\begin{array}{r}100 \\
94\end{array}$ & $\begin{array}{l}85 \\
82\end{array}$ & $\begin{array}{l}10 \\
14\end{array}$ & $\begin{array}{l}5 \mathrm{ss} \\
4 \mathrm{ss}\end{array}$ & 1 quartz \\
\hline$\frac{\text { STON Y CLAYS }}{\text { Dash wood, }}$ & & & & & \\
\hline exposure 20 & 236 & 85 & 8 & $1 \mathrm{ss}$ & $\begin{array}{l}5 \text { qte. and argil- } \\
\text { lite, } 1 \text { quartz }\end{array}$ \\
\hline Black Point & 132 & 91 & 6 & $2 \mathrm{ss}, 1 \mathrm{sh}$ & 1 limestone \\
\hline
\end{tabular}

The pebbles at most localities were collected by breaking up fresh till or stony clay and picking out all stones 1 to 3 inches in diameter until the total reached about 100. The larger collections of pebbles were screened from mechanical analysis samples. 
The Dashwood toll sheet characteristically includes partings of poorly sorted silt, sand, and pebble gravel. In most places, the partings are a fraction of an inch to a few inches in thickness and are relatively inconspicuous, but, on the northernmost part of the Denman Island sea cliff, they are several feet in thickness and intergrade with a very silty till to form a glacial complex (figure 16) unlike the simple t11l. sheet exposed elsewhere.

The full thickness of the till sheet has been seen only at Black Point, where it is 9 feet, and at Dashwood, where it ranges from 10 to 30 feet. The exposed thickness of the Denman Island complex is 80 feet and the lower contact has not been seen. The bese of the till sheet has been traced only at Dashwood (cross-sectjon, Plate IA) where it follows the undulating (erosional?) surface of the underlying sands wi th relief of at least 100 feet. The tjll mantles this surface as a veneer of remarkably unj form thickness and such thianings and thickenIngs as are present seem unrelated to the underlying topography. On Derman Island south of the thick complex the upper contect of the till sheet departs no more than 10 feet from high tide line for at least a mile. Here the till ei ther lies on a horjzonteil surface or else completely fills and masks irregularj ties in the underlyjng topography. Comparison with Till of Vashon Group

Distinction of the Dashwood till sheet from that of the Vashon group has been based upon stratigraphic succession, end only 


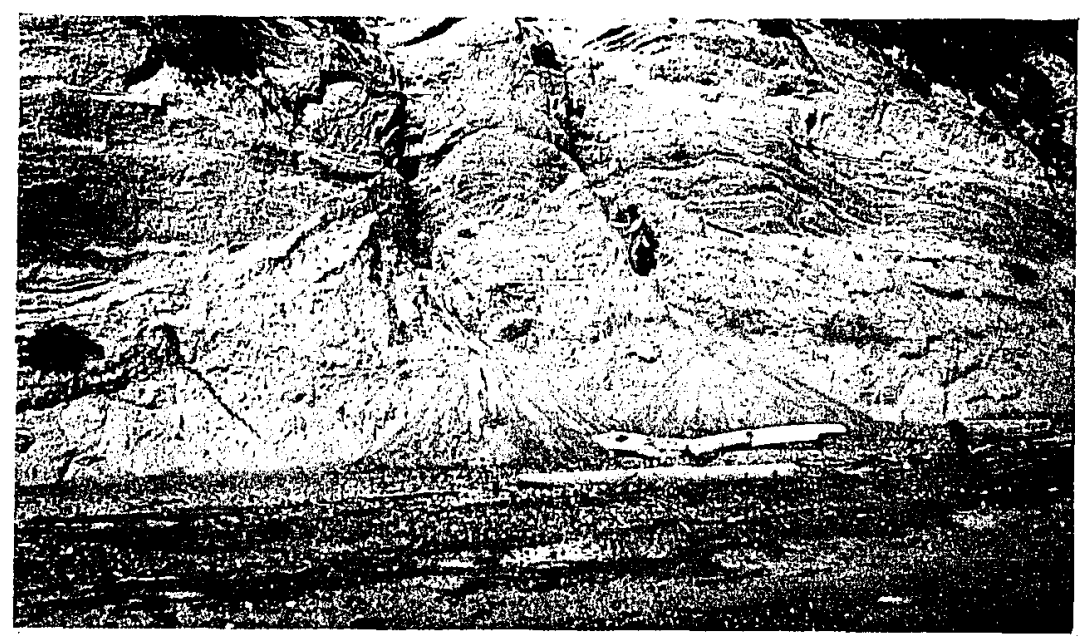

Figure 16. "Glacial complex" of Dashwood group consisting of irregular beds and lenses of silty till and poorly sorted silt, sand, and gravel. Exposure near north end of Komas Bluff, Denman Islands. 
locelly are they distingul shable on the basis of their textural or other physical characteristics. Thus, although very sandy "type" tills of the Vashon group, conteining about 30 per cent of gravel and boulders, are distinctly different from the silty tills of the Dashwood group at Dashwood, Black Point, and Denmen Island containing less than half as much gravel, tills of the two groups at French Creek and Chef Creek are texturally indistinguishable (for comparfsons see Fjgure 14). Pebble counts of superimposed or nearby tills of the two groups reveel only minor and local differences in percentage of the various stone types (Table I) and the few, weakly orlented fabric diEgrams of Dashwood tills (Fjgure 15) show no distinctive differences in preferred orientation from the Vashon till fabrics.

\section{Assocjated Glaciel Movements}

Pebble counts and febrjc analyses 4 of the tills of the Dashwood group provide little indication of the associated glacjel movements. Fabric analyses of five tills (Fjgure 15) show no

\footnotetext{
4 In determining till fabrics, a more or less horizontal surface 18 to 30 inches across was excavated in the till and the azimuth of the long axes of the exposed pebbles was measured to the nearest 5 degrees with a Brunton compass. Then successive increments of till were removed from the surface and the orientation of pebbles was recorced (in the same way) as they came to view until the total reached 100. Equidimensional pebbles and pebbles whose major diemeter was steeply inclined were not recorded. The pebble orientations were then plotted in 10-degree intervals on a rose diagrem. The preferred fabric orientation of the till is considered to be that of the modal interval in its rose diagram; or where several modes are present, the preferred orientation is estimated from the shape of the di agran.
} 
unjformity in preferred orientation. Three of the fabrics are so diffuse that a radius vector summation (Krumbein, 1937, p. 687) was required to determine the preferred orjentetion. The pebble counts (Table I) seem to indicate a random sampling of the resistant rocks of the adjoining parts of the Georgia depression. The universal presence of granitic rocks, however, seems to exclude the possibility that the tills were deposited by local glaciers flowing off the Beaufort Range. Striae and related features on the lower mountain slopes bordering the Georgia depression and on the cosstal lowland (See Figure 50, and djscussion of Vashon group) provide abundant evidence of southeast glacial movement and local evidence of earlier south to southwest glacial movement. It is tempting to suggest that the earlier south to southwest movement was associated with the till of the Dashwood group and the later southeast movement with that of the Vashon group. However, fabric orlentations of the "type" tills of the Vashon group (see Figure 15) form two disperse groups trending south to southwest and east to southeast parallel to the two strike directjons. Therefore, both movements recorded on the rocks probably correlate with the Vashon group.

Accumulation and dispersal of glacial ice in a mountainous region such as this would be controlled in large measure by the topography, and therefore the directions of glacial movement during successive gleciations of the region may well have been similar. That the ice movements associated with the Dashwood group were, indeed, similar to those that have been outlined for the last glaciation 
(Vashon group) is suggested by the similarity of the pebble counts (Table I) of the tills of the tro groups.

\section{LAMINATED CLAY}

\section{Matorials and Field Relations}

1 leminated clayey deposit up to 10 feet in thickness lies upon the till of the Dashwood group in most of the mapped exposures. Typically, it forms a well-defined unit of pale grey clay and clayey silt with prominent laminations a fraction of an inch to an inch in thickness. In some places, however, the laminae are indistinct, and, except for the absence of marine shells, the unit differs little from the overlying marine stony clay. Locally the laminated deposits are missing and the marine stony clay lies directly on the till. The laminated unt in some places contains partings of till-like pebbly and sandy silt, and appears to be gradational between the silty till below and the marine stony clay above.

The laminated clays characteristically have a silty rather than clayey consistency and are rather poorly sorted. A representative sample from Dashwood (sample 53-6, Figure 17), has a median grain dimeter in the clay-size range at $0.003 \mathrm{~mm}$. but its modal diemeter lies in the silt range at $0.008 \mathrm{~mm}$.

\section{Mode of Formation}

Because the laminated clay and sjlt lfe directly on glacjal till and contain lenses of till-like material, they are inferred to be of glaciolacustrine and/or glaciofluvial origin. They are identical. in nature and occurrence to materials that lie between the till of the 

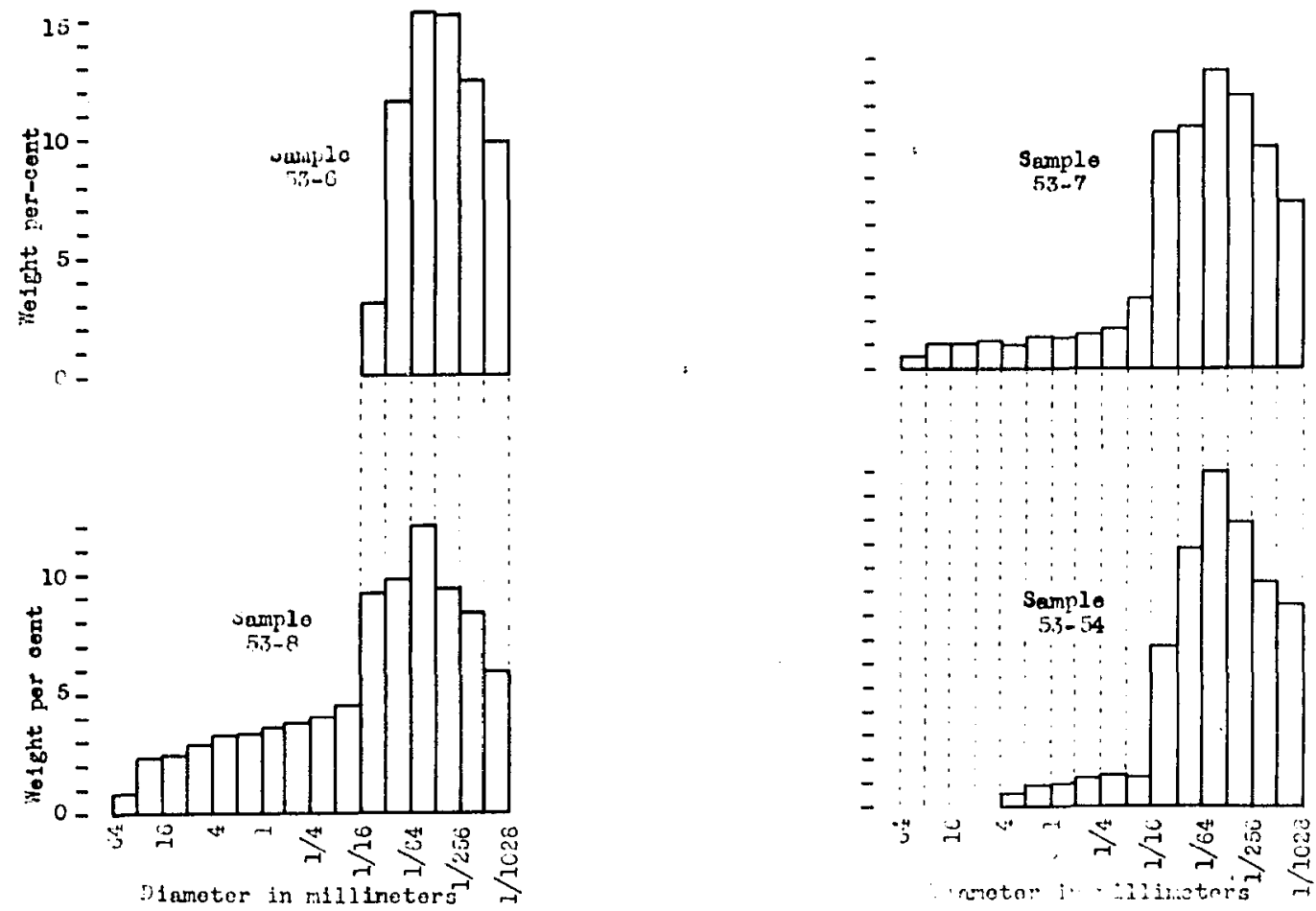

\begin{tabular}{|l|c|c|c|c|}
\hline Sample & $53-6$ & $53-7$ & $53-8$ & $53-54$ \\
\hline Locatjon & Dashwood sea cliff, exposure 20 & Denman I sland \\
\hline $\begin{array}{l}\text { Material } \\
\begin{array}{l}\text { Per cent of } \\
\text { gravel and } \\
\text { sand }\end{array}\end{array}$ & $\begin{array}{c}\text { Laminated } \\
\text { clay }\end{array}$ & $\begin{array}{c}\text { Stony clay } \\
\text { (typi cal) }\end{array}$ & $\begin{array}{c}\text { Stony clay } \\
\text { (stony) }\end{array}$ & $\begin{array}{l}\text { Stony clay } \\
\text { (tjpi cal) }\end{array}$ \\
\hline $\begin{array}{l}\text { Median } \\
\text { diameter (mm) }\end{array}$ & 0.0031 & 12 & 32 & $\begin{array}{c}6 \\
\text { (sand only) }\end{array}$ \\
\hline $\begin{array}{l}\text { Modal } \\
\text { diameter(mm) }\end{array}$ & 0.008 & 0.0050 & 0.019 & 0.0040 \\
\hline $\begin{array}{l}\text { Sorting } \\
\text { coefficient }\end{array}$ & 4.5 & 0.010 & 0.012 & 0.010 \\
\hline
\end{tabular}

Figure 17. Grain-size histograms and mechanical analysis date for stony and laminated clays of the Dashwood group. 
Vashon group and the superincumbent marine clay, and whj ch, as suggested in Chapter 8, may have been deposited in a narrow zone of fresh water beneath glacial ice where a floating tidal ice shelf set the grounded part of the glacier.

\section{STONY CLAY}

Poorly sorted clay containing sand, gravel, boulders, and marine shells lies upon the till and laminated clay of the Dashwood group wherever they have been found, except at Chef creek (locality 5 , Figure 11). The writer beljeves that the coarse materiul in the clays was derjved from floating jee and therefore assigns the clays to the glacial Dashwood group. At the Chef Creek exposure, the marine beds overlying the Dashwood till are silts that do not contain stones but enclose spruce cones and grade laterally into sands and silts with drifthood layers typical of the quadra group. The marine beds at this localjty have therefore been assjgned to the Quadra group, although it is conceded that they, liave formed at the same time as the stony clay of the Dashwood group and in the same marine body. This separation of marine and glaciomarine deposits is arbitrary and their distinction is possible only because of the small number of Dashwood group exposures involved in this report. In a study of a larger area, it might be simpler to group them together as a single marine unit of the Quadra group.

\section{Materials}

The stony clay typically is massive and similar in appearance to very clay-rich till (see Figures 18,19), but, here and there, layers 


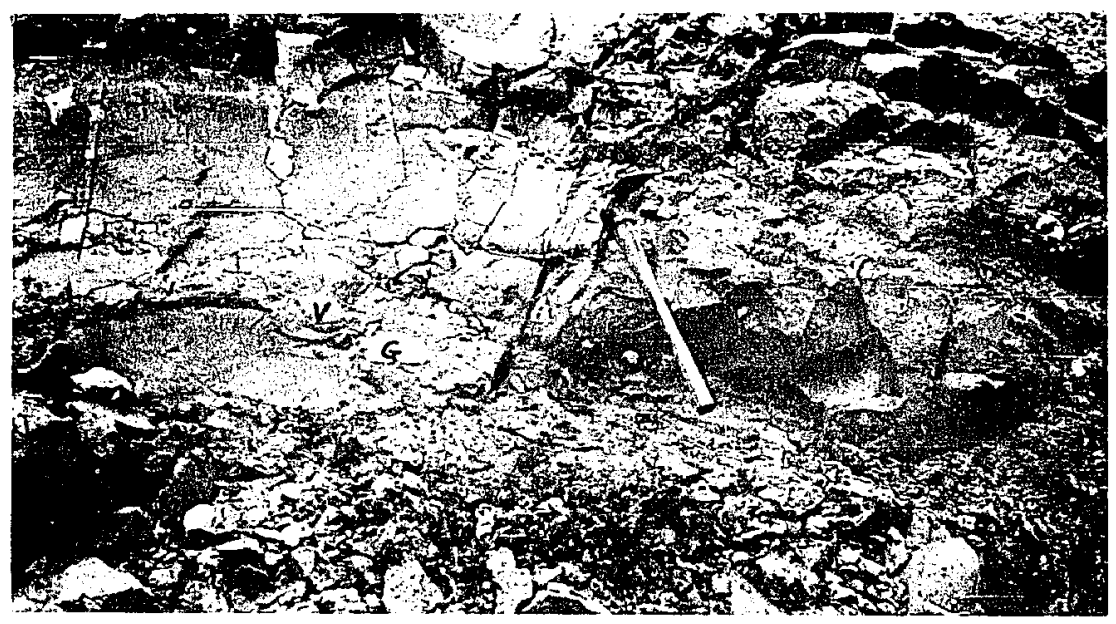

Figure 18. Stony clay of Dashwood group, Komas Bluff, Denman Island. $G$ is a granitoid cobble, $V$ is a volcanic cobble。 $A$ band of white barnacle shells extends across the right half of the photograph a few inches above the pick.

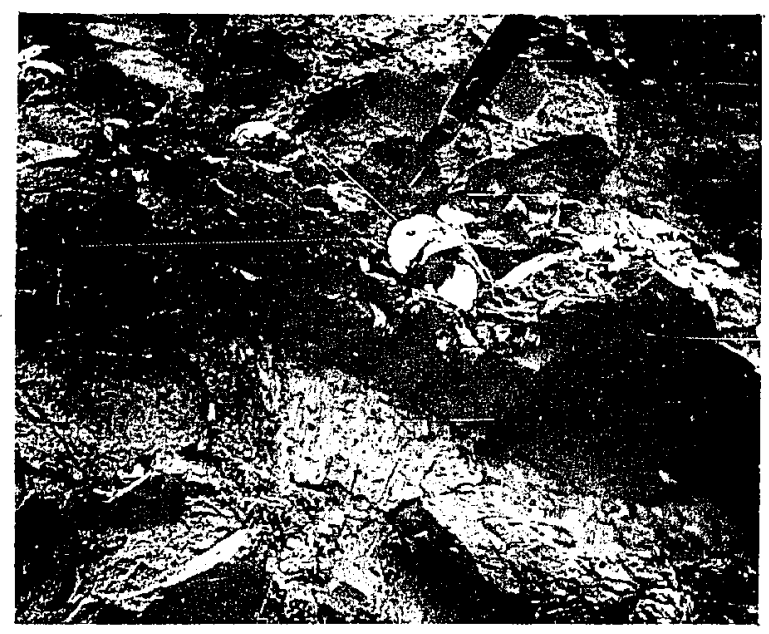

Figure 19. Large barnacle shells (Balanus evermani ?) in stony clay of the Dashwood group. Same exposure as Figure 18. 
of pebbles or shells or discontinuities in drying properties outline indistinct bedding planes. It is generally blue-grey, but where organic content is especially high, fresh surfaces are black and the clay emits a fetid odour. The stony clays are poorly sorted mixtures of clayand silt-size particles (clay and silt typically in equal proportions) and contain a few per cent of sand, gravel, and boulders. Average stony clays contain about 10 per cent of sand- to boulder-sjze materjal but some especially stony varjeties contain more than 30 per cent of coarse material. Grain-size histograms of three samples of stony clay (Figure 17) jllustrate the distinction betreen the clay-silt matrix, represented by the modal portion of the graphs, and the admixed coarse material. Despjte differences in the sand and gravel content of the three analysed samples, the clay-silt matrices are very similar to one another and to the one sample of the underlying, stone-free, laninated clay, os illustrated by their almost identical modal diameters. Pebbles in the stony clays at Dashwood and Black Point include about the same proportion of grani toid to volcanic types as those in samples of the underlying till (Table I) but are more angular than those in the till.

\section{Organic_Remaing}

Shells of marine molluscs and hara parts of a few other marine invertebrates are present in almost all know unoxidized exposures of stony clay of the Dashwood group. They are numerous in some places and rare in others, and seem to be as abundant in the most stony materials as in those that are almost stone-free. The shells are typically unbroken; many pelecypod shells are paired or even closed 
in their growing position; and barnacle and Serpula shells have been found attached to stones.

Miss F.J.T. Wagner of the Geological Survey of Canada has studied seven collections of shells from the stony clays of the Dashwood group at Dashwood, Blacic Point, and Denman Island (Vagnex, 1954). The list of species supplied by Miss Vagner consists entirelyr of modern forms. The median of midpoints of the ranges of species in each assemblage extends from 49 to 57 degrees north latj tude and similar assemblages live today in the Gulf of Alaska and in Norton Sound between 60 and 63 degrees lati tude. The assenblages appear to represent an epineritic rather than ljttoral envjronment.

\section{Contacti and Thicioness}

At jts basal. contact, the stony clay typically lies conformably upon the laminated clay. The upper contact, wi th the peatbearing beds of the Guadra group, is gradational in some places but erosional in others. On Denman Island, the upper contact of the stony clay is horizontal, like the basal contact, and is gradational rather than erosjonal. Here the uppermost few feet of narine material typically are almost stone-free, become progressively more silty, and are marked by a succession of pale greenish bands from which the calcareous shell material has been removed by leaching and which appear to be incipient soils. On the Dashwood sea cliff (cross-section Plate IA) the stony clay is of variable thickness and the upper contact forns hills and hollows similar to, but only in part conforming wi th those of the bottom contact. Parts of this upper contact at Dashwood are transitional but parts are veneered wi th a lag concentration of gravel and boulders like that on the present erosional beaches of the region. 
The normal thickness of the stony clay, 3.3 exposed at Denman Island, Black Point, French Creek, and throughout much of the Dashwood sea cliff is 15 to 20 feet. At exposure 7 in the western part of the Dashwood sea cliff (cross-section, Plate IA) the stony clay is more than 80 feet thick (base not exposed) whereas, one half mile to the east at exposure $12 \mathrm{it}$ thins to zero for a short distance, possibly as a result of erosion.

\section{Mode of Deposition}

Despite the till-like appearance of the stony clay of the Deshwood group, it is believed to be a primary marine deposit because of the unbroken and undisturbed condition of the contained iarine shells and because it is locally stratified. Nonetheless, the admixture of stones and sand wi the silt-clay matrix, and the clear distinction of matrix from the coarse fraction seem to indicate that the conditions of deposition were complex and possibly that the component materials came from two separate sources. Such mixtures could result from sub-marine landslides or from mixing of normal sea-bottom muds wi th gravelly material dropped by floating debris or floating ice. In addition, stony muds are found, and apparently are forming, in the lowtide zone along parts of the present shore of Vancouver Island. The stony clay of the Dashwood group is much thicker than these modern intertidal muds ( 10 to 80 feet as opposed to 1 to 3 feet) and the marine fossils in the Dashwood clays include only rare intertidal forms. The Dashwood stony clays contain no slump structures and the random distribution of the large stones in the clays cannot be explained by 
slumping. Formation of the stony clay is therefore ascribed to mixing of rafted stones and sand with sea-bottom mud, and, on account of the size and quantity of stones involved, the rafting agent must have been floating ice rather than floating logs or other debris. The rafting may have been done by bergs derived from glacier tongues or floating ice shelves or merely by sea $j$ ce. If the climate of the Georgia depression were cool enough to perant the accumulation of appreciable amounts of sea $j$ ce in Georgia strait, glacjers probably would also be discharging bergs into the strait. Therefore, the stony clay is classified as glaciomarine even though some (perhaps much) of the ice that is inferred to have carried the stones may not have been glacial.

Little is known of the extent of the submergence associated with the stony clay of the Dashwood group. The known deposits are all less than 150 feet above the present sea-level, although, a local pocket of marine silt and clay on Finglishman River, that probably correlates with the Deshwood deposits (see below), is 250 feet above present sea-level.

\section{DISTRIBUTION OF DASHWOOD DEPOSITS WITHIN THE AREA}

The Dashwood group has been identjfied in only half a dozen cliff sections, but in view of the distribution of these exposures (FIgure 11) and the continuity of the Dashwood strata at Denman Island and Dashwood, the group probably is widely distributed beneath the coastal part of the map-area. Dashwood materials almost certainly remain unrecognized amid similar materials of the Vashon and Capilano groups, particularly in erosional areas where the overlying fuadra group is known to be present. For instance, Dashwood deposits are probably present beneath a lag gravel veneer along the valley of Nanoose Creek 
where it parallels the highway and adjacent to the Escuimalt and Nanaimo Railway east of Craig. In addition, many exposed successions, particularly in the higher parts of the coastal plajn, include possible equivalents of the Dashwood group but differ sufficiently from the standard succession that their correlation with the named groups is uncertain. For instance, on Englishman River two niles below the falls, the following deposits form an erosional rennant 200 feet long between shale bedrock and a 40-foot till sheet:

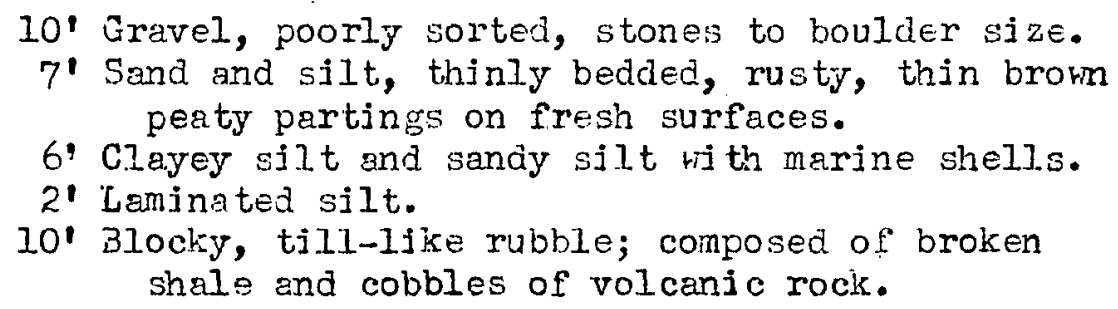

The shell-hearing beds, the laminated silt, and the basal till-like rubble probably correlate with the Dashwood group. Between Thames Creek and Cowie Creek are ridespread gravels that locally contain peaty beds and that have been tentatjvely correlated wi th the Guadra group; tills and dirty gravels beneath these in a few exposures nay be correlative with the Dashwood group. In Alberni Valley and along some of the valleys of the Beaufort Range, discontinuities within the exposed tills (such as boulder pavements, gravel beds, and pronounced changes in texture or stone content) provide abundant evidence of complex history but, as yet, no evidence has been found to indicate whether all the tills are equivalent to the Vashon of the coastal belt or whether some of them are correlative wi th the Dashwood. Such successions of tillis are tentatively placed in the Vashon group in this report. 
CORRELATIVE DEPOSITS OF THE GEORGIA DEPRESSION

The Dashwood group has been defined above as the lower of two groups of glacial deposits in the "standard" succession of the map-area, and depositi can be assigned to, or correlated wjth, the Dashwood group only where their positjon in or relative to the "standard" succession is known. Tills occurring beneath white sands beneath an upper till sheet at Cape Lazo a few miles northwest of the map-area (Dawson, 1887, p. 105) and on Texada Island (McConnel1, 1914) probably correlate wi th the Dashwood deposits. In the Saanich map-area, at the southeast end of Vancouver Island, stony clay at Cowi chan Head and stony clay and till at Cordova Bay occur in the lower part of a succession of unconsoljdated deposits very similar to the "standard" succession of the Horme Lake and Parksville map-areas and may well be equivalent to the Dashwood group. Clapp included these stony clays (Clapp, 1913, p. 115) in the Maywood clays of the Puyallup interglacial epoch and probably assigned the till to the Admiralty glacial epoch al though he makes no specific mention of $i t$. On the other hand, many of the Maywood clays and Admiralty tills mapped or described by Clapp appear to be equivalent to the Capilano and Vashon groups of this report rather than the Dashwood.

In the Lower Fraser Valley region, as outlined in Chapter 3, Armstrong and Brown (1953) have identified two groups of buried glacial deposits, the Seymour group and the Semiamu group. Till of the Seymour group underlies peat-bearing beds that have been correlated wi th the type Quadra group at Point Grey, which, in turm, appears to be equivalent to the Quadra group of Vancouver Island. On this basjs, the 
the Seymour group can logf cally be correlated wi th the Dashwood. On the other hand, the possibility that the Semjamu group correlated wi th the Dashwood cunnot be ignored. 
CHAPTER 6

\section{QUADRA GROUP}

DEFINITION AND COMPONENTS

The name Quadra group has been used by J.E. Amstrong and W.I. Brown (1953, formatjonal table) for sands forming white prominent cliffs on Point Grey, at Vancouver. In this type section, the Quadra group includes the pert-bearing beas designated by Johnston (1923) as the Point Grey fomation. In the coastal lovland of the Home Lake and Parisville map-area ( see Figure 20), and in many other places throughout the Georgia depression, are very sinilar sends wi th the same distinctive white colour and uniformity of stratification, the same association with peaty beds, and apparently occupying the same stratigraphic position. On the basjs of this sinjlarity of occurrence, the writer has applied the name Guadra group in the map-area to the sonds and peat-bearing beds lying between the Dashwood group and the till of the Vashon group.

In the Point Grey section, nei ther the base of the Guadra group nor the underlying deposits are exposed, and Armstrong and Brom (1953) define the Quadra simply as "intertill sediments". In using the same name in the Horne Lake and Parksville areas the writer defines it In terms of the "standard" succession, and takes as hjs type locality the Dashrood sea cliff where both upper and lower contacts of the group have been traced for three miles (see cross-section, Plate IA). Because the lowest intertill sediments, the stony and laminated clays, are jncluded in the underlying Dashwood group in this report, the definition of the Guadra is changed to "intertill non-glacial deposits". 
At Dashwood, and as typically developed throughout most of the coastal lowland, the Quadra sedinents fall naturally into two divisjons: a lower distinctively coloured peat-bearing succession of silt, sand, and gravel, and a thick upper succession of white sands. In a few places, as for instance on the Comox sea cliff, peaty beds are Intercalated with the white sands. Between Thames Creek and Cowle Creek, where streams have cut into the higher parts of the coastal. plain, are numerous exposures of thick unconsolidated sedinents differing from the "standard" succession but locally Including peaty beds. The peaty beds and the enclosing thick series of pebble gravels and silty sands, occurring beneath an uppermost till sheet, are tentatively correlated wi th the Quadra group.

PEATY BEDS OF THE QUADRA GROUP

\section{Basal Peat-Bearing Strata}

Greens sh and rusty-orange silt, sand, and gravel, and oljve grey to brown peaty beds lie upon the stony clay of the Dashwood group and make up the most distinctive unit of the "standard" succession. They have been found in the places marked in Figure 20 and are also extensively exposed along Komas Bluff on Dennan Island.

The appearance of the unft and the nature of the component sediments are uniform throughout the area but the sequence of beds within the unit varies from place to place. The four measured sections outlined below illustrate the nature of the peaty unit on the Dashwood sea cliff where 1 t ranges in thickness from 10 to 40 feet. In each exposure, the peaty unit rests on stony clay of the Dashwood group and is covered by thick white sand. 


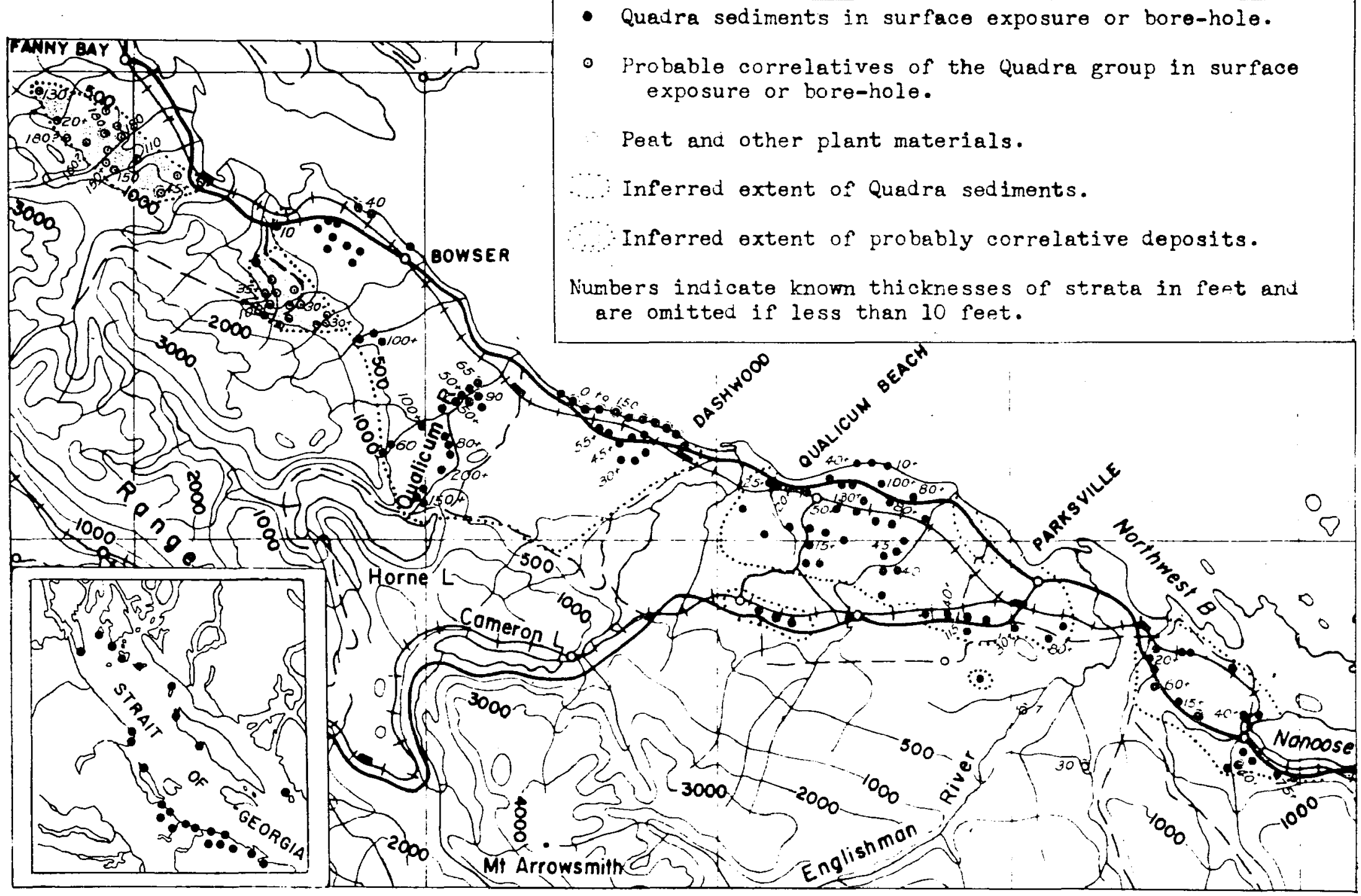

Figure 20. Distribution of Quadra sediments, Horne Lake and Parksville map-areas; inset shows known occurrences of Quadra-type sand in northern Georgia hasin. 
Exposure 4 Dashwood cross-section, Plate IA.

$3:$
$1^{\prime}$ 6"
$4^{\prime}$
$2^{\prime}$
$0^{\prime} 9^{n-}$
$4^{\circ}$
$7^{\prime}$

Silt, horizontally stratified.

Sand, medium-grajned.

Covered.

Pebble gravel, fine-grained, well-sorted, rusty.

Silt, fine sand, peaty partings.

Pebbly sand, coarse-grained, silt partings, rusty.

Pebble-cobble gravel, well-sorted, indistinctly stratiffed, includes silty sand lenses wi th twigs.

Exposure 18, Dashwood cross-sectjon. Plate IA.

o' 6" Sand, very fine, brown and peatr.

1: 6" Sand, very fine, black and mottled.

I' On $^{n}$ Covered.

1' On $^{\prime \prime}$ Pebbly loam, brown, peaty.

3. Pebble gravel, rusty.

2' Gravelly silty sand, greenish.

Exposure 20, Dashwood cross-section. Plate IA.

$5^{\prime}$ Silt with leaf imprints, peaty partinga, flattened twigs. $5^{\circ}$ Gravel, rusty in upper part, green in lower part, lateral change from stratified fine pebbly gravel to cobbleboulder lag concentrate.

Exposure 29. Dashwood cross-section, Plate IA.
1' Silt contrining twigs.
3' 4" Peat containing twigs; includes peaty sand layers and
$34^{\prime}$ pebbles at the base.
Pebble gravel, horizontally stratified, cross-bedded.

Southwest of Dashwood, similar peat-bearing successions are exposed at two places on French Creek (Locall ty 1, Figure 1I) between sand and stony clay. In the upstream exposure, $1 \frac{1}{2}$ feet of peaty silt are underlain by 3 feet of rusty pebble gravel, and in the downstream exposure, 1 foot of grey silt rests upon $2 \frac{1}{2}$ feet of brownish silt with peat and pebbly partings. West of the Dashwood sea cliff on Qualicum River (Locall ty 3, Figure 11) the peaty unit is represented by 10 inches of brown, silty, peaty soll underlain by 10 feet of rusty, cross-bedded 
pebble and cobble gravel with two peaty partings.

The basal peaty beds of the Quadra group are very well exposed on Denman Island (see Figures 21, 22). The thickness of the unit here ranges from 8 to 35 feet. One of the more complex successions through the unit, between stony clay and white sand, is as follows:

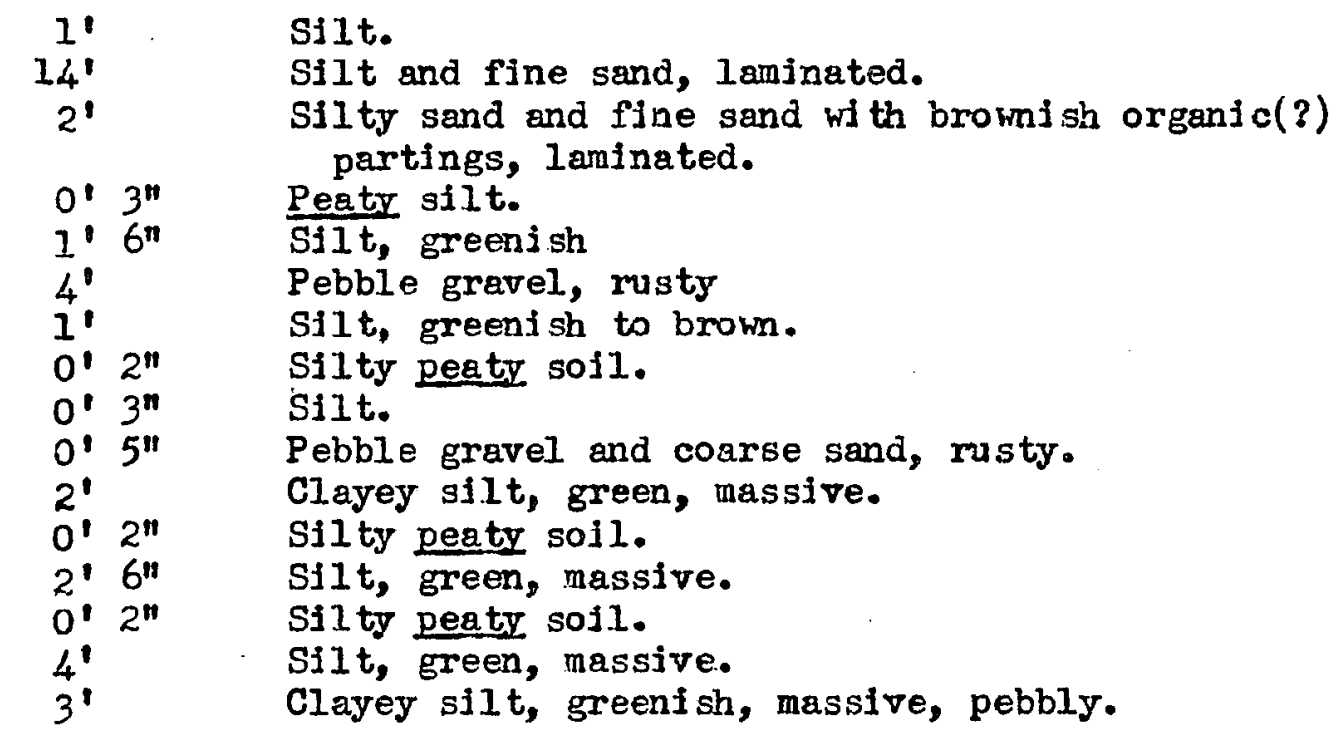

Near the northwest end of the Denman Island exposures, the peat-bearing unit clearly grades upward from the stony clay of the Dashwood group as jllustrated in the following succession. Erosional Surface $2^{\prime}$
$3^{\prime}$
$0^{\prime} 8^{n}$
Silt, greenish and white with brownish peaty layers. Pebble gravel, rusty, hori zontally stratified. 61
Silt, pale greenish, contains three brown peaty layers.
Silt; greenish, pale grey, and whi te horizontal bands outline three incipient soil profiles. Gasts of marine shells in lower part. Stony clay, blue-grey, contains marine shells.
Gravels of the peat-bearing unit of the Quadra group are typically well sorted and consist of well-rounded pebbles. Most of the component stones are volcanic al though a few per cent everywhere are 


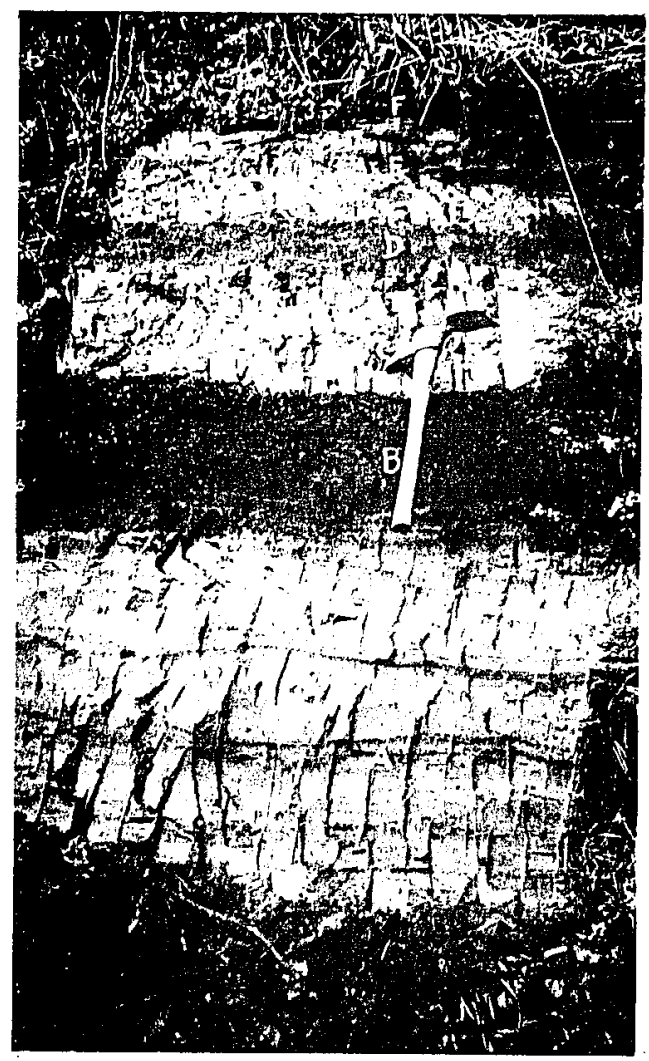

Figure 21. Part of the basal peaty unit of the Quadra group, Denman Island. A, green silt with thin peaty layers (dark); B. rusty-orange pebble and granule gravel; C, green silt; D, musty-orange coarse sand; $E$, green silt with peat lenses (dark); F, woody peat 3 inches thick (partly obscured by overhanging vegetation). 


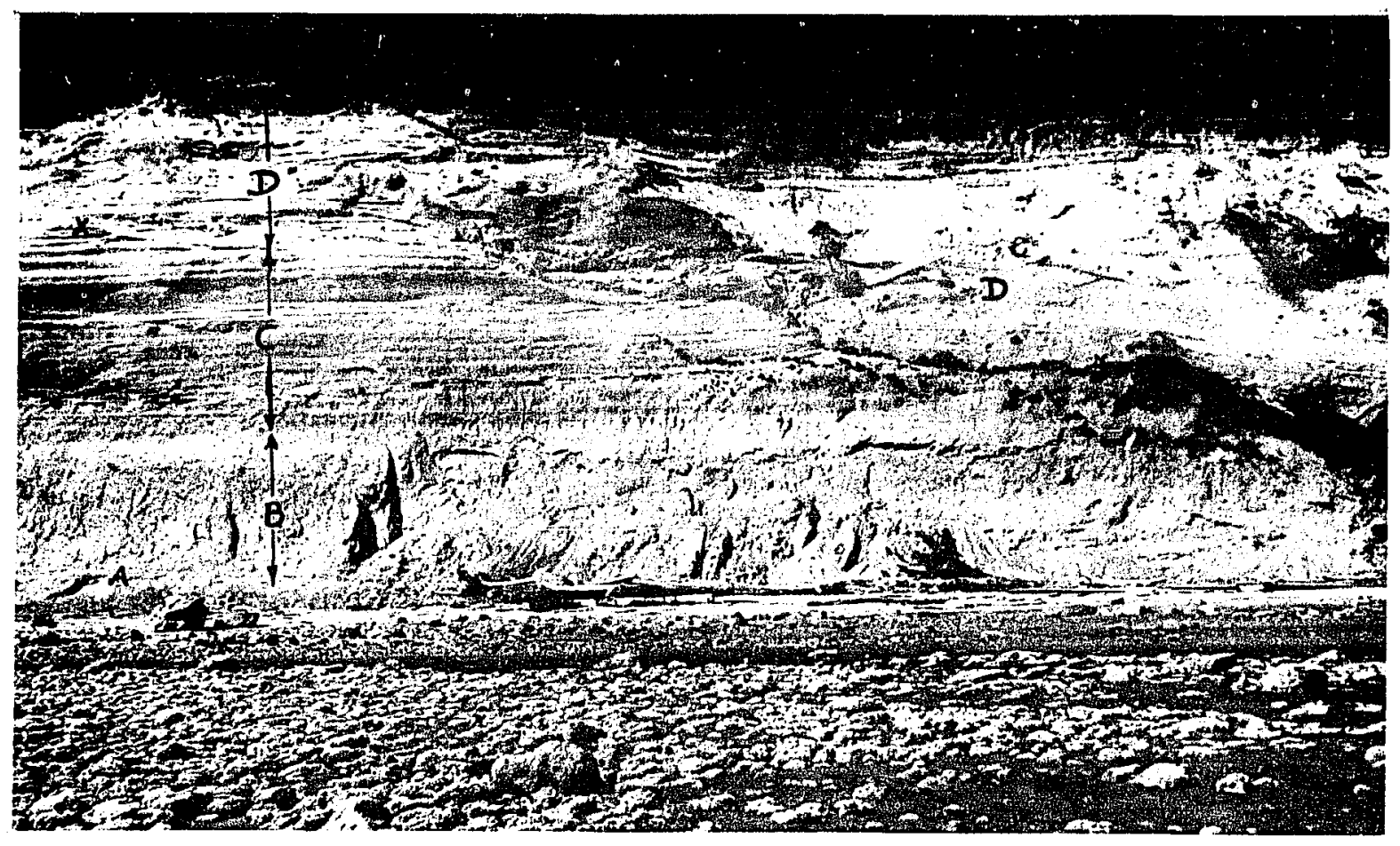

Figure 22. Part of the Komas BIuff, Denman Island, exposing laminated clay (A) and stony clay (B) of the Dashwood group overlain by silt and gravel (C) of the quadra group containing thin peaty beds. Above the erosion surface $(X-X)$ are post-glacial marine sands and gravels $(D)$. 
granitoid. Gravels in three places on the Dashwood sea cliff contain 70 to 88 per cent of volcanjc pebble, 10 to 18 per cent of granj toid pebbles, and rare pebbles of quartz, chert, schist, and shale; gravels in two places on Denman Island contain 92 and 69 per cent volcanic pebbles and 7 and 4 per cent granitojd pebbles. These pebble counts are very similar to those of the underlying Dashwood deposits. The rusty colour typical of the gravel of the peat-bearing unjt occurs as an 1 ron oxjde (?) filin coating the pebbles, and the pebbles themselves are relatively unweathered.

Sjlts associated wi th the peaty beds are compact, wellsorted, and are thick-bedded rather than laminated. One sample from Denman Island that has been subjected to mechanjcal analysis has a median diameter of $0.011 \mathrm{~mm}$. and sorting coefficjent of 1.98. Two samples of silt from Denman Island, one green and the other brown, have been examined microscopically. Both contain a remarkably large proportion of epjdote, chlorjte, and green cryptocrystalline material, and the brown sample appears to contain as much of these green components as the green one.

Colours of sediments of the peat-bearing unit of the Quadra group are distinctive and appear to be related to the associated plants and plant materials. The yellow green to oljve colour of many unoxdized beds (Mumsell colour chart designation $5 \mathrm{GY} 5 / 2,10 \mathrm{Y} 6 / 2$ ) is exclusively associated with buried plant materials of the Guadra group, whether peat, peaty soil, leaf accumulation, or driftwood. This colour is probably due to the presence of ferrous iron compounds formed by the reducing action of (or assocjated with) the plant materials, both during the existence of the depositional boggy environment and ofter 
burfal beneath the overlying sediments. Most gravels and sands associated with the peaty beds are rusty-orange in colour and some of the green silts are mottled with the same colour. This colour is partly the result of recent oxidation of green materials, al though in gravel and sand beds beneath peaty layers, it probably developed through soll-forning processes during deposition of the peaty materials. Peats, peaty "solls", and other layers containing plant materials are charscterized by yellow brown to olive grey colours (Munsell colour chart desfgnation IOYR $4 / 2,5 Y 5 / 2$ ) that are unlike the colours of other brownjsh sediments of the area and provide a reljable basis for recognjtion of sediments contajning finely divided vegetable matter. Beneath some of the peat and peaty soil layers and in each of the incipient soil profiles of the Denman Island section outlined above, are ashy-white layers an inch or so in thickness. Microscopic examination of samples of the white materials revealed no concentration of diatoms and no mineralogical peculfaritses that would account for this why te colour. The white materials probably are bleached (reduced) or leached (podzol) layers like those in some modem organic soll profiles. Individual beds within the peat-bearing undt appear to be horizontal and relatively uniform in thickness and character as seen on most of the avajlable exposed faces, but changes in the succession of strata from one exposed face to the next attest to the lenticular nature of the individual beds. On Denman Island, both contacts of the peatbearing unit are horizontal for at least a mile whereas, at Dashwood the unit rises and falls through about 100 feet following the hills and depressions of the underlying Dashwood and sub-Dashwood deposits. Variations in the thickness of the peaty unit at Dashwood seem to bear 
no consjstent relation to these hills and hollows and are similar in magnitude to the thickness variations on Denrnan Island.

\section{Peaty Beds of the Comox Sea Cliff}

On the sea cliff east of Comox, brow peaty silts and green to rusty-orange silts containing wood and imprints of leaves are found within the sand unit of the Quadra group. The sands extend down to sealevel, and therefore it is not known whether the basal silt-gravel-peat unit is present or whether it is here replaced by the peat-bearing part of the sand unit. The peat-bearing part of this Comox exposure consists of thin, regular, horizontal beds of medium- to fine-grained and intercalated with less numerous beds of silt. The plent materials and the associated distinctive coloration are confined to the silt beds, and the sand beds between them are like the typical quadra sands discussed later in this chapter. The peat-bearing part of the sand succession is about 50 feet thick at the northerst end of the sea cliff and thins progressively southwestward to be replaced entirely by nomal quadra sand near the southwest end of the cliff. One measured section midway along the cliff contains 6 thin peaty soil layers, as shown below.

70 feet above high tide: $3 / 4$ inch peaty silt within 10 inches silt with casts of twigs.

55 feet above high tide:

1 inch peaty silt.

51 feet above high tide:

4 Inches peaty silt and peat resting on 10 inches brown silt.

40 feet above high tide:

Three 1 to 3 jnch layers of peaty silt separated by silt and fine sand. (illustrated in Fi gure 23). 


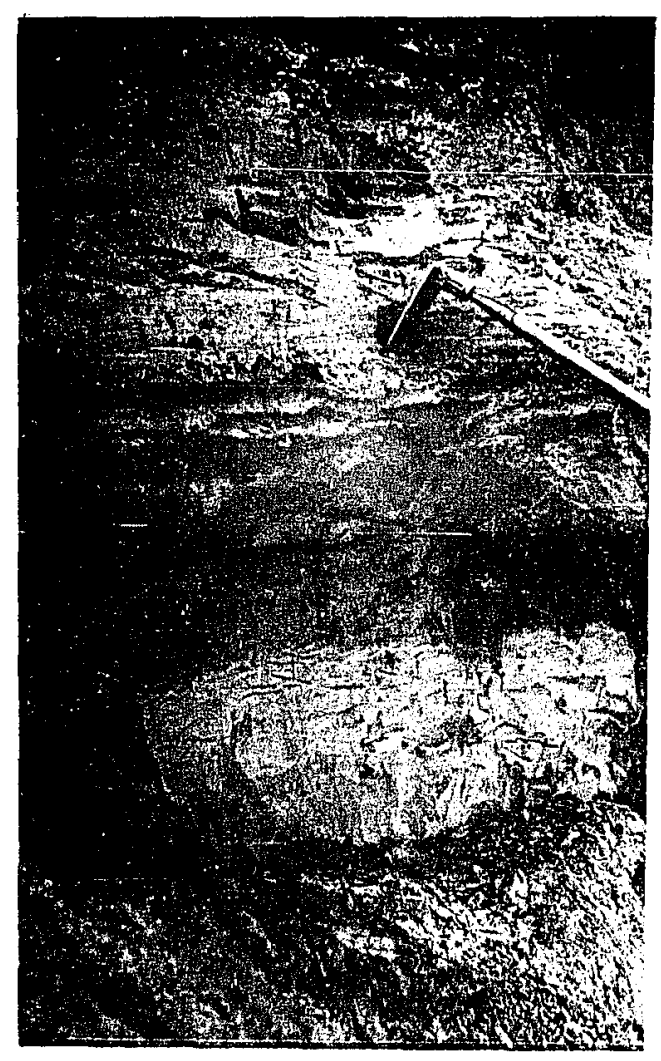

Figure 23. Peaty silt layers ( 3 dark layers below shovel blace) in sand and silt of the luadra group, Comox sea cliff. 
Farther to the southwest, in the part of the sea cliff illustrated in Figure 25, the plant-bearing part of the sand succession is less than 20 feet in thickness. Only one peaty layer is present but several silty beds contein casts of sticks, and rusty partings in one bed of green silt bear tell preserved inprints of closely packed leaves.

\section{Chef Creek Section}

A cutting on the Island Highway east of Chef Creek (Iocali ty 5, Fjgure 11) exposes Dashwood, Cuadra, Vashon, and marine Capilano deposits as a succession only 30 feet in thickness. As shown in Fjgure 24, intertill sand and silt dip away from a small knob of tjll of the Dashwood group extending just above the road level. The beds resting directly on this till are silts containing rarine shell.s and rare spruce cones. These shell-bearing beds hedge out to the west and grade upward into fine and then coarse sand. To the east, both the shell-bearing silty beds and the overlying sand grade laterally Into thin-bedded silt and fine sand with numerous driftrood layers. These last are continuous beds a fraction of sn inch in thickness, consisting of a mat of small twigs, needles of conifers, and tiny (apparently abraded) wood fragments. Scattered within the woody mat are stjcks up to 3 inches in dianeter and several feet in length. Bark is still intact on some sticks but others have lost thejr bark and thejr ends are rounded as if by abrasion. Some silt beds adjacent to driftwood lajrers on the north side of the cutting exhibit the green and orange-rusty colours typically associated wi th peaty beds of the fiuadra group. 


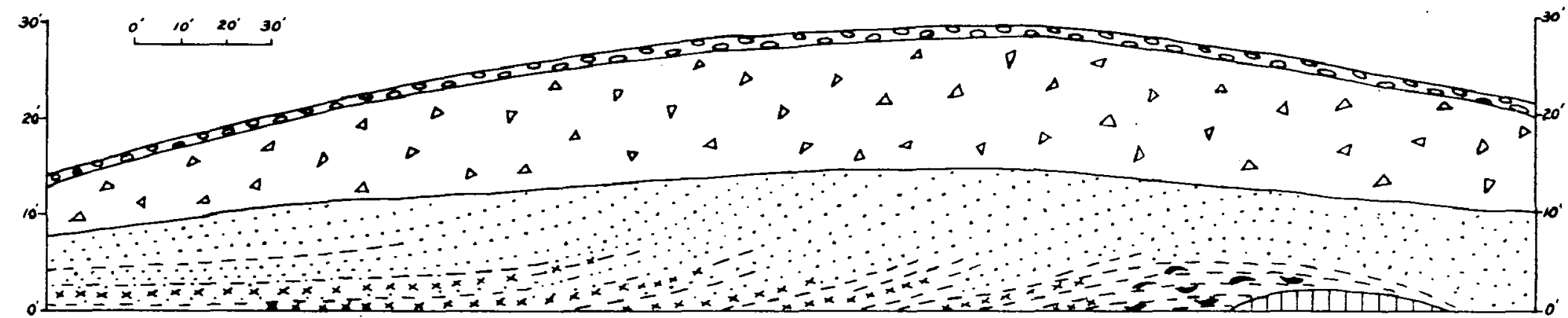

CAPIIANO GROUP

$\therefore$ Gravel, till-like material, silt containing casts of marine shells, clay.

\section{VASHON GROUP} $\triangle$ Till.

Figure 24. Sketch of cut bank, south side of Island Highway a quarter of a mile east of Chef Creek. Scale approximate.
QUADRA GROUP

Medium to coarse sand.

Silt and very fine sand.

Peaty driftwod accumulation.

Marine shells.

DASHEOCD GROUP

1111 Till. 


\section{Organic: Remains}

Peat of the Quadra group is characteristically dark yellow brown, compact, wood-like material consisting principally of finely cominuted plant remains and tiny sterns or rootlets. These peats grade laterally and vertically into paler brown, more friable peaty "soils" containing a variable proportion of admixed mineral matter. Imprints of sedges, grasses, and seeds are clearly visible on parting planes of many of the peaty strata. Flattened branches and stems of woody plants up to 3 inches across are scattered throughout the peaty materlals, though only locally are they abundant. Bark is typically intact on the sticks and. al though their ends are broken, they show no sign of stream or wave abrasion. Roob of woody plants have not been Identified in the peats or peaty "solls" but, because of compaction and flattening, they may remejn unrecognized among the stems and branches. On Denman Island, one peatj bed half an inch in thickness consists of a carpet of moss in its growing position. Pollen enalysis of peats and peaty "soils" of the Quadra group from Bonnell Creek, French Creek, Dashwood, Denuan Island, and Comox has been attempted by Dr. J. Terasmae of the Geological Survey of Canada, but unfortunately, the materials studied to date are almost devoid of pollen grains. Dr. Terasmae has jdentifjed a number of species of fresh water diatoms in peatjr inaterials from Denman I sland.

Insect wings and wing casings and a few well-preserved insects have been found in peats of the Quadra group within the maparea. Insect remains from very similar peats (probably stratigraphic 
equivalents of the Quadra sediments of the map-area) at Lynn Creek near Vancouver and at Cordova Bay near Victoria are reported by Pierce (Pierce and Draycot, 1948, p. 35) to include "part of an Elaphrus elytron, and elytral fragnent of a Phellopsis, possibly porcata Leconte, many Donacia, and several species of small bettles, Lepodopterous pupal remains, and the beautiful psyllid wing described in Article 3." This last is ascribed by Pierce to a new genus and species Dracotia cordovae, of the family Chernidae.

The peats, peaty soils, and other plant-rich layers of the Quadra group form the uppermost horizons of sojl profiles. Most of these are bog and half bog soils, 8Ithough the usual blue-grey "glej" colour is not found in the mineral soil horjzons beneath the orgenic a accumulations. Possibly chemical reactions since burial have converted the glei to the greenjsh material characteristically associated with the organic beds. A few soil profiles, in which the brown peaty horizon is underlein by a thin white horizon, eppear to be groundwater podzols. In other soil profiles, the upper peaty orgenic layer rests upon a rusty substratum of gravel or coarse sand. Dr. A. Leahy of the Soll Survey Service of the Canadian Department of Agriculture has briefly examined two such profiles and has suggested that they are similar to the moor soils of Great Britain. On Denman Island, alternete green and wite silt layers an inch or two in thickness, lying on stony clay of the Dashwood group and containing casts of marine shells, appear to be a series of superposed incipient soil horizons. Mr. L. Farsted of the Soil Survey Service of the Canadian Department of Agriculture has suggested that these profiles are similar to those found in recently silted-up marine marginal lagoons of the 
region.

Well-preserved imprints of leaves on rusty partings in green silt from the plant-bearing part of the Guadra group at Comox have been shown to several botanists but, so far, the leaves have defjed specifjc identification. Most of the leaves are are sinjlar to willow and a few are probably Vaccinjum or et least belone to the Ericacae. Needles of conifers are absent. The mode of occurrence of these leaves and epparently the leaves themselves are similar to leaves reported from the Point Grey formation (cuadra group) of Point Grey by Berry and Johnston (1922).

Driftwood from the Guedra sedjments at chef ireek and from rusty pebble beds of the peat-bearing unit on Denman Island has been studied by Dr. V.C. Brink of the University of British Columbia. He reports (personal communication) from the following tentative identiflcations from the corposite collection, based upon sticks an inch or more in diameter.

\begin{tabular}{|c|c|}
\hline $\begin{array}{l}\text { Spruce (possibly Picea sjtchensis) } \\
\text { Pine (Pinus contorta) } \\
\text { Hemlock (Tsuga Sp.) } \\
\text { Cedar (probably Thuja plicata) } \\
\text { Abjes? }\end{array}$ & $\begin{array}{l}\text { abundant } \\
\text { abundant } \\
\text { common } \\
\text { rare } \\
\text { one doubtful specinen }\end{array}$ \\
\hline
\end{tabular}

These trees grow at present on Vencouver Island, but the assemblage, lacking in Douglas fir and. wi th abundent spruce, is more typical of the coastal foregts north of Prince Rupert. Because of inadeauate sampling this distinction may be of little signjficance. Nonetheless the driftwood certainly includes trees typjcal of the British Columbja coast and the Gulf of Alaska thet do not grow north of Cook Inlet (latjtude 61 degrees north), whereas marine shellis from the stratigraphically equivalent marine silts at lhef lreek are reported by Miss Wagner 
(1954, p. 82, 98) to be most similar to the modem assemblages of Norton Sound in the Bering Sea (lati tude 62 degrees north). A7. though this djfference nay inerely reflect sampling errors, $j$ t rajses the possibility that the clinatic distribution of these forms in the past may not have been exactly analagous to the present. For instance, as brought out by Schenck (1945) the latjtude of modern inoliuscan assemblages of the Alaska coast is several degrees north of the medjan of mid points of the lati tude renges of the component species; this crowding of the merine molluscs into the northem part of their range may be a temporary situation and need not have obtajned during deposition of the Quadra deposits.

As inentioned above, sticks in the peats and peaty "soils" of the Quadra group are flattened as if by the weight of overlying materials. Sticks in the woody drjftwood mats of the Chef creek exposure are also flattened but less markedly than those in the peats, but those in gravels and silts associated with the peaty beds have not been flattened. Thus flattening of the sticks appears to be dependent upon the peaty environment and is not necessarily the result of the load of thick overlying sedjments or thick glacial ice.

SANDS OF THE GUADRA GRGUP

Between the basal peaty beds of the Quadra group and the till of the Vashon group are pale-coloured, vell-sorted, horizontally stratified, and extensively cross-bedded sands up to 250 feet in thickness. These sands are exposed in many places in the map-area, as shown in Figure 20. They form prominent white cliffs along rivers and the sea shore where erosion has penetrated below the base of the 
Vashon till and, in adajtion, occur at the surface or below a few inches of lag gravel where wave action along fomer higher sea shores has removed the overlying till. Identification of sands as belonging to the Quadre group depends essentially on recognition of thej $r$ position in the "standara" succession. In general, any thick, white, horjzontal sands beneath till have been assiened to the quadra group unless other evidence suggests that they belong in the sub-Dashrood deposits. Similnr sands that are not covered by till may be cuadra. deposits that have been uncovered by erosion or may be marine or deltajc deposits of the Capilano group derived from a Guadra sand source. Distinction of cuadre sands from Capjlano sands in such circumatances is aided by (1) the strictly horizontal attitude of sands of the Guadra group in contrast to the undulating or foreset stratification of the Capilano deposits, (2) the locel presence of marine shells or shell casts in Ciapilano sands, and (3) the presence, on sands of the guadra group, of a lag reneer of stones (particularly boulders) left during erosion of the Vashon till; large stones very rarely are found on the surface of marine lapjlano deposits.

Most cliff exposures of the Guadra sand wi thin the maparea are near the coastal edge of the lowland and some distance from the mountain front. In such exposures, the sand succession conisists of medium- to very fine-grained sand and includes only rare interbeds of coarse sand and pebble gravel. Along Qualicum River, however, sands of the Guadra group are exposed at intervals across almost the full width of the coastal lowland (a quarter of a mile from Home Lake to $1 \frac{1}{4}$ miles from the sea shore). Near the sea, the succession is dominantly medium- and fine-grained sand, as described above, and rests 
upon the peaty beds of the Guadra group, but farther inland it contains numerous beds of coarse sand and pebble gravel. In the exposure nearest to Home Lake, these coarse materials comprise as inuch as half of the strata, which here rest directly on bedrock. Sinilar coarse sand and pebbly sand of the Guadra group are exposed to the nor thwest near the inland edge of the coustal lowland on the south fork of Hunts Creek (60. feet overlying bedrock) and on Nile Creek (100 feet wi th base not exposed). Northwest of Nile Creek in the coastal lowland adja cent to the mountain front are sub-till gravels, sands, and silts rather different from the normal Guadra sedinents. They may represent a further textural change of the sand succession of the Quadra group but, so far, can only be tentatively correlated wi th the Quadra sediments, as outlined later in this chapter. A pit at the junction of the filbemi Hjghway wi th the Frrington rosd exposes about 40 feet of well-sorted pebble gravel beneath rennants of till. The gravel, whose full thickness is not known, has been assigned to the Quadra group and the overlying till to the Vashon. Stones in the gravel are 75 per cent volcanic, 20 per cent granitoid, 1 per cent sandstone and shale, and include 1 solated pebbles of quartz, chert, quartzite, and white weathered honeycomb rock of a type seen in the Permian strata along Horne Lake. The horizontally stratifjed, crossbedded gravels are intercalated with a few beds of clean sand and, in the eastem part of the pit, the upper 10 feet of gravel is replaced by sand. Shallow excavations both east and west of the gravel pit encountered typical cuadra sand, and a well boring less than a quarter of a mile to the east encountered only 10 feet of gravel 40 to 50 feet 
below the surface within a 115 foot section of sand (data provided by J. Reinsford of Pacific Water Wells Limited). Thus, the gravel encountered in the Exrington pit probably is of no great extent; it may well be a river channel within the sands.

Sand of the quadra group up to 240 feet in thickness is exposed along Komas Bluff on Denman Island, northwest of the maparea. In the lower 150 feet of this succession, the sand is principally medium to coarse grained and a few beds of pebble gravel are present, whereas in the upper part the sand is typically finer grained. Within this upper part of the sand succession are distinctjve pinkish-white beds that appear on the cliffs as wet, almost vertical faces and that, unlike the incoherent sands that surround then, break up into chunks like a soft sendstone. These beds consist of horizontally laminated, well-sorted sand in which a small amount of clay coats the grains and partly fills the voids between the grains. Many of the Jaminae wi thin these beds contain abundant magnetite. The Guadra sands of the Comox sea cliff are similar to tho se on Denman Island except that they contain peaty materials. Figure 25 shows the comox succession a few hundred yards from the southwest end of the cliff, where about 150 feet of sand is exposed above high tide. Unjt $C$ in this figure includes beds of pinkjsh coherent sand impregnated with clay. Like the similar beds on Denman Island, they contain numerous magnetj te-rjch laminae.

Stratifjcation of the sands of the Quadra group is regular and horjzontal in almost all known exposures. Tabular and lentjcular cross lamination are very abundant except in the coherent 


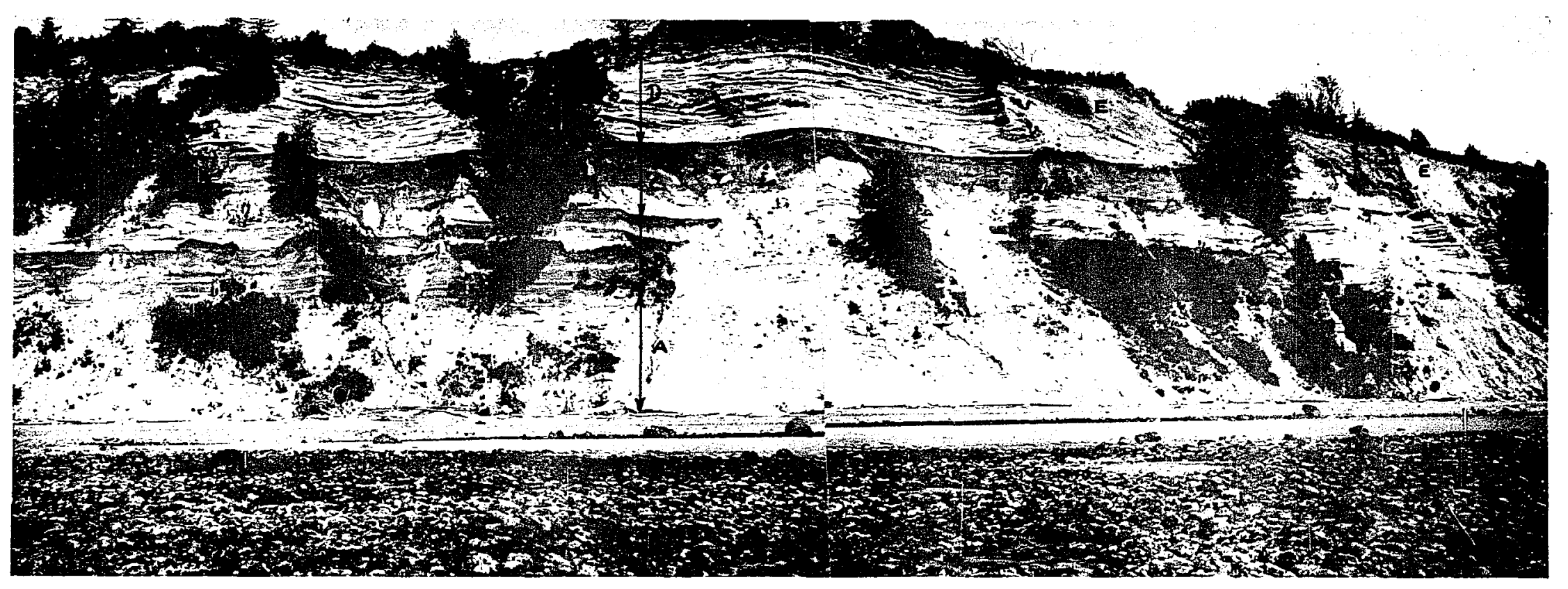

Figure 25. Sands of the gadrat group, conox set clirf, near the southiest end of the cliff. The face is about 150 feet high. Note truncation of the send by till (E) right of centre, and thinning of the clay-impregnated sands (C) towaras the richte Letterea unj ts are as follows; units $A$ to $D$ constitute the Guadra group.

F. Till of the Vashon group.

D. Medium-grained sand.

c. Medium and fine sand alternating with becis of coherent, clay-jbpreencted sand containing magneti te layers.

B. Medium and fine sand intercelated hj th green silt contajning hood casts, leaf imprints, and a peaty layer.

A. Medjum to $\cos r e$ na. 
pinkj sh sands of Deninan Island and at Comox (see Figure 26). Individual beds ere generally a few jnches to a foot or two in thickness, al though a few cross laminated units in the lower part of the succession on Dentnan Island attain a thjckness of several feet. The direction of dip of cross lamination of the sands is not consistent, even wi thin a single stratur. A statistical study of the dip direction of cross-laminated bed; exposed along Cualicum River and on Dashwood sea cliff reverled no preferred orientation. Nonetheless, the sand exposures at Nanoose Bay, Dashwood, Denman Island, and lomox convey the impression that the cross laminations have a preferred dip to the southeast or south.

Mechanical analyses of ejght sands of the Quadra group are illustrated in Figure 27 . The five samples of fine-grained sand (samples 53-40 to 53-44 inclusive) are typical of the sand unit. Thej $r$ average median grain size is $0.16 \mathrm{~mm}$. The coarsest sample (medium-grained sand, 51-2) is from one of the pinkish coherent sands with interstitial clay on Denman Island. Sorting coefficients renge from 1.21 to 1.57. Examination of these sanas with a binocular microscope revealed that they consist dominantly of feldspar and cuartz. On the basis of an approximate estimate, about half of the grains are feldspar, one-quarter quartz, and one guarter hornblende, biotite, and other dark mineral grains. Hormblende is the dominant dark constituent in most samples but biotite is more abundant than homblende in two of those examined and magnetite makes up 10 per cent of another. Rock grains are rare in all samples. Grains composing the sands are typically clean, wi thout clay coatings or staining. Most 


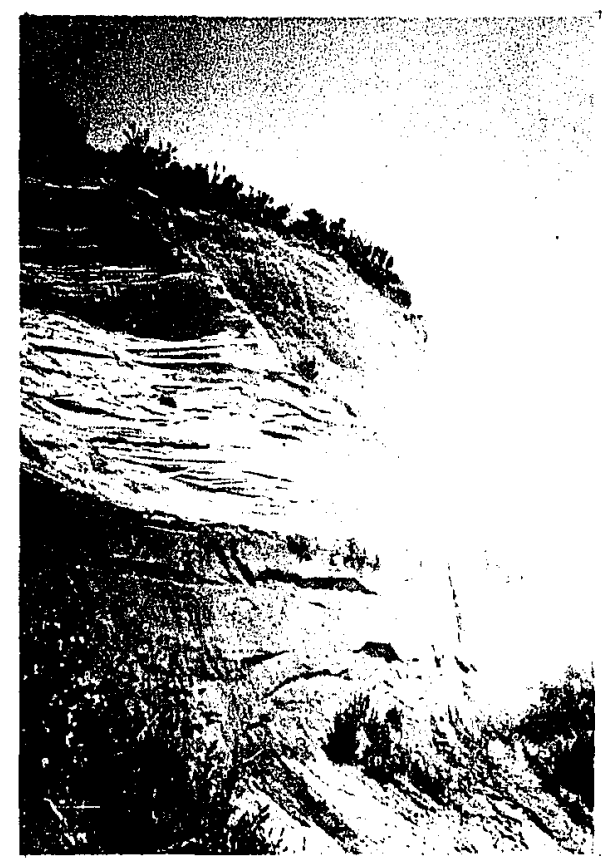

Figure 26. Typical Guadra group sand (pale colour) w th crosslamination resting on coherent, clay-impregnated sand wi th horizontal lamination. The till in the upper right is several tens of feet behind the sand; the sand-tjll contact is not visible. Thj face, which is 35 feet high, forms part of the Comox sea cljff. 


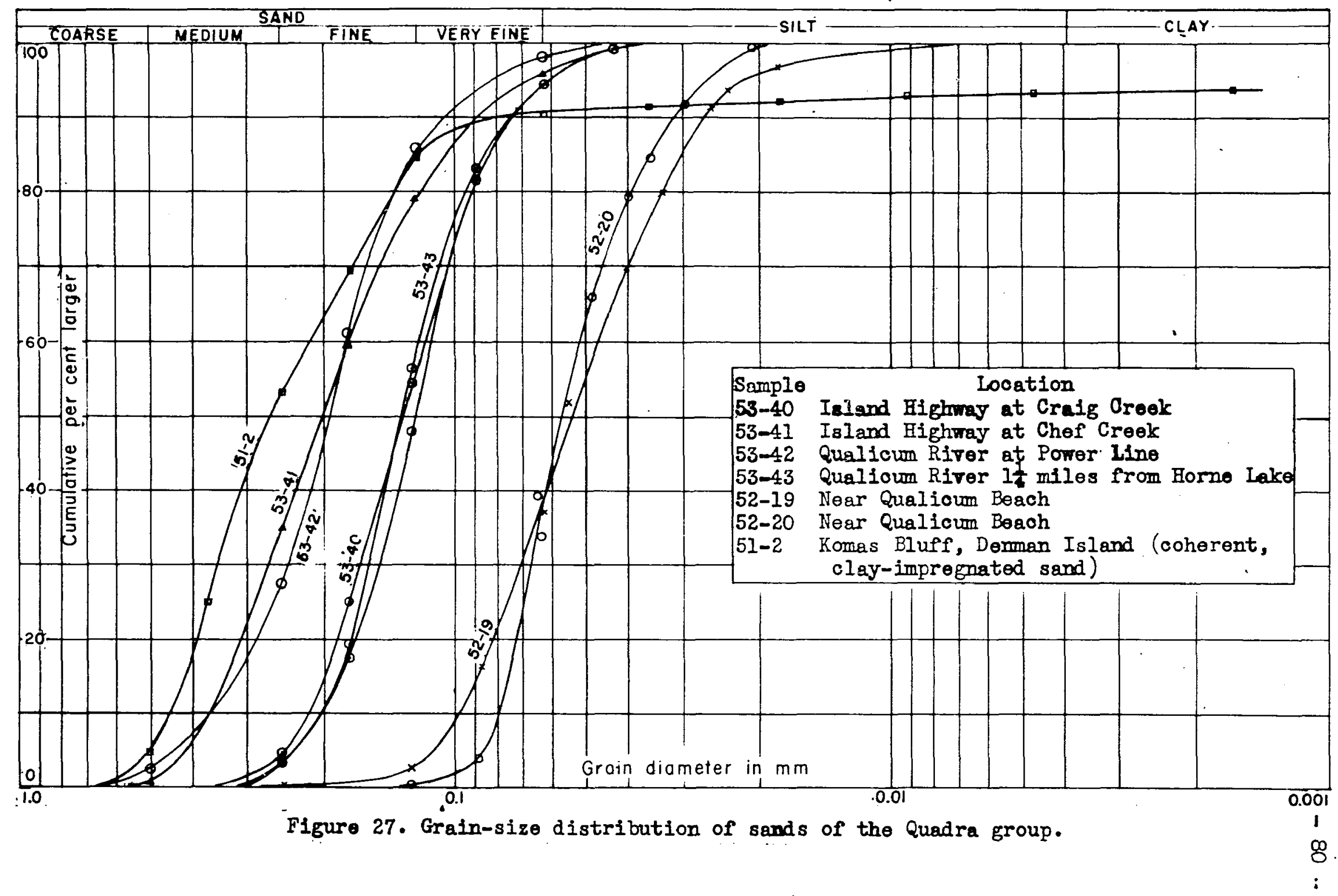


Most are anguiar al though the few grains more than $\frac{\mathrm{L}}{\mathrm{m}}$. In diameter are subrounded. J.M. Cummings (1914), in reporting on possible sources of siljca sand in the Strait of Georgia region, stated that the minus 20 mesh, plus 100 mesh fraction of "bank sands" (wuadra group?) froin Qualicum River consist of 18 per cent quartz, 54 per cent feldspar, and 28 per cent dark grains (mafjc minerals, rock grains, woathered grains), and his Table 1 fllustrates that the mineral composition of "bank sands" (Quadra group?) from Nanoose Bay, Cortez Island, Hernando Island, Savary Island, Harwood Island, and Thormanby Islands is similar. He reports (194], p. 3) that most "bank sands" (quadra group?) in the northern part of the Georgia depression "consiat essentially of plagioclase and quartz, with lesser amounts of other minerals. The constituents of this group are present in proportions approximating those of quartz diorite. All the accessory minerals, with the exception of topaz, tournaline, kyanjte, and phlogopjte, have been reported in coast Range batholithic rocks." Regarding feldspar grains in sands of the Georgia depressjon, Cumings reports (194I, p. 5): "Wi th the exception of a very small proportion of potash. feldspar, their composjtion lies between albj te-oligoclase and andesine."

Sands of the Quadra group lie conformably upon the peaty silts and gravels in most places where the lower contact has been seen, but in the highway cutting just east of Chef Creek, where the normal peaty beds do not occur, the sands grade upward and laterally from both marine silts and silts containing ariftwood beds. Elsewhere, Zuadra sands overlap on to the bedrock. The upper surface of the sands 
is everywhere erosional and the present distribution and thickness of the sands have been modjfied by this erosion surfece. Evidence of the erosion and inferences regarding its signjficance are considered near the close of this chapter.

Quadra group sands are continuous and remarkably unj forn over large areas. Thus they are exposed wi thout a break for about a mile on the Comox sea cliff and have been traced through closely spaced exposures for about 3 iniles on the Dashwood sea cliff, along Qualicum River, and on Denman Island. As Shown in Fjgure 20, they appear to underlie about one third of the coastal lowland section of the map.area. Their patchy distribution is controlled partiy by hills and hollows in the surface upon wich they lie, partly bj the erosion surface along their contact with the Vashon till, and partily by irregularities in the present ground surface. Nowhere is there any evjdence suggesting that the sands were deposited as $\mathbf{j}$ solated or local bodies. On the other hand, their remarkable unjformi ty of texture and stratifjcation throughout the region, their horjzontal attitude, and the absence of any "eage effects" such as changes in grain size, sorting, or stratification except where they abut against hills in the underlying topography seen to indicate that they were formerly much more extensive than now and that the present $i$ solated patches may be remants of a continuous deposit.

DEPOSITS PROBABLY EQUIVALEN T TO THE QUADRA GROUP

Along the inland part of the coastal lowland of the map-area are thick successions of strata differing from the "standard" successjon and that have not been correlated wi th the "standard" succession. 
Among these deposits are gravels, sands, and silts that lie beneath till and locally contein peaty beds, and that probably are ecuivalent to the suadra group. The most extensive of these deposits are wellsorted pebble gravels that $1 j$ s beneath a. few feet of till between wud Bay and Cowie Creek, in the zorthwest part of the map-area. Cut banks along the valleys of Waterloo Creek and hilfred (Coal) creelk expose up to 150 feet of these gravels and explorktory bore holes drilled for Canadien Collierjes (Dunsmuir) Limited between Wilfred ureek and Cowle creek encountered up to 180 feet of gravel and sand. The known exposures and inferred extent of these gravelly deposits are shown in Fjgure 20. Sone of the stretigraphic sections including these gravels are outlined below; the deposjts inferred to be equivalent to the Quadra group are marked iti th an $x$.

1. East branch Waterloo Creek, 1.1 miles from E. BNA. Railway. Elevation at top 520 feet.

10' Tili.

$x$ 10' Pebble-cobble gravel.

$x$ 15' Silt, sand, and fine pebble gravel.

$x$ 12' Rusty silt and fine sand, thin peat bed, casts of rood and leaves.

6' Lovered.

$x$ 6' Fine pebble gravel.

2. Waterloo lreek, west bank, 1.1 mjles from E.\&N. Rajlway. Elevation at top 480 feet.

25' Delta gravel.

5 Till.

$x$ 18. Silt, sand, pebble gravel.

$x$ 90 Incomplete exposures pebble gravel and coarse sand, beds dip down the velley.

20. Sandy till and cemented gravel.

80' Covered to stream bed. 
3. Waterloo Creek, west bank, 2.5 miles from Eold. Rajlway. Elevation at top 620 feet.

$10^{\prime} \mathrm{Till}$.

$x$ 150 Incomplete exposures of well-sorted pebble Eravel and

10. Ti.li, silty to pebbly.

$25^{\prime}$ Silt, fine sand, pebble beds.

201 Pebble gravel.

$40^{\prime}$ Covered.

-- Sandstone.

4. Wilfred Creek, west bank, 1.5 mjles from E.\&N. Rajlway. Elevation at top 550 feet.

10 Tili.

$x$ 100'. Small exposures of clean pebble gravel and sand.

$x \quad 2$ Silt.

$150 \cdot$ Covered.

301 Till.

-- Sendistone.

5. WiIfred Creek, west bank, 1.3 miles from F.\&d. Reil way.

$x$ 85' Incomplete exposures of clean pebble gravel with

sandy interbeds; bedding lenticular.

$x$ 10' Silt-filled gravel. Beds dip up the valley.

$x$ 55' Slump slopes of sand and pebbles (in place?).

$x$ 2.0 Laminated silt and sand with pebble gravel interbeds; wood imprints and $\frac{1}{\vec{z}}$ inch peat bed.

50' Cemented bouldery grovel and sand; poorly sorted,

265' Covered. bedding inclineá.

-- Shale.

Along the upper part of Chef creek and Thames Lreek, cut frees and gullies expose up to 100 feet of pebble gravel, sand, and silt beneath a few jnches to a few feet of till. In many places, the overlying till is so thin that it is completely broken up in the sojI profile. On the steep gullied slope where the mein branch of chef Creek reaches the base of the mountain slope, stratified gravels, sands, and silts blanket the steep rock face through a vertical range of 400 feet. Till overijes these deposits in only a few places and it has not been possible to determine whether all of these materials were once 
covered by till of whether some of them were formed later than the till as jce-contact deposits. The sub-till deposits are typically well sorted and regularly, horjzontelly stratjfied. Stones comprising the gravels are of pebble to sinall cobble size and most are well rounded; most consist of the ubiqui tous green volcanic rocks al thou a few are sandstone or granodiorite. The sands resernble typical white sands of the Quadra group. The Quadra sediments nearest to these deposits, along Nile Creek, contajn numerous gravel beds, and possibly the subtill gravelly deposits along Thames Creek and Crief Creek are a still more gravelly phase of the Guadra group. However, parts of the sub-tjII surface (as reflected by the present ground surface) bear small, very shallow closed depresstons. These depressions may be modffied kettle holes and, if so, the sub-till deposits probably should be correlated with the Vashon group rather than the Guadra.

Very local sub-till peaty sands and silts that have been found in two places along the Englishman River system probably are equivalent to the Guadra group. Two miles down Englishman River from the falls the following strat form a lens about 200 feet long between shale and till (see Fi gure 28).

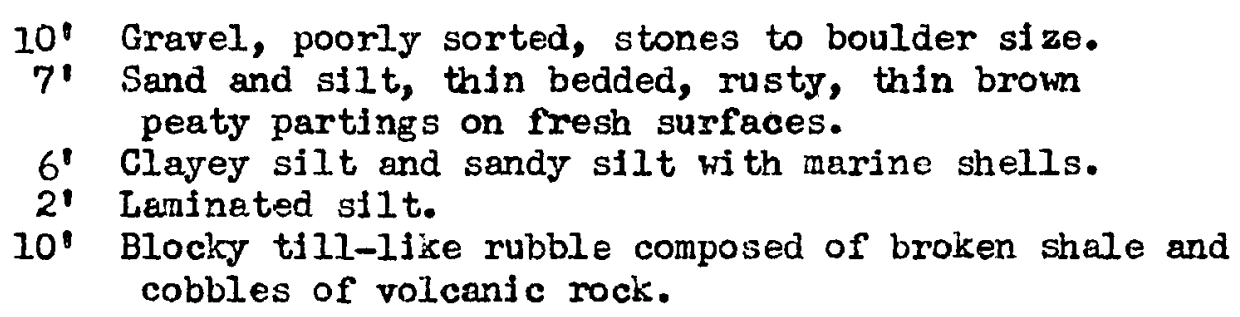
cobbles of volcanic rock.

This lens appears to be an erosional remnant of a much more extensive deposit and probably owes its preservation to the sloping face of shale against which it rests. The 7 foot section of peaty beds is tentatively correlated wi th the Quadra group. Beneath the Northwest Bay logging 


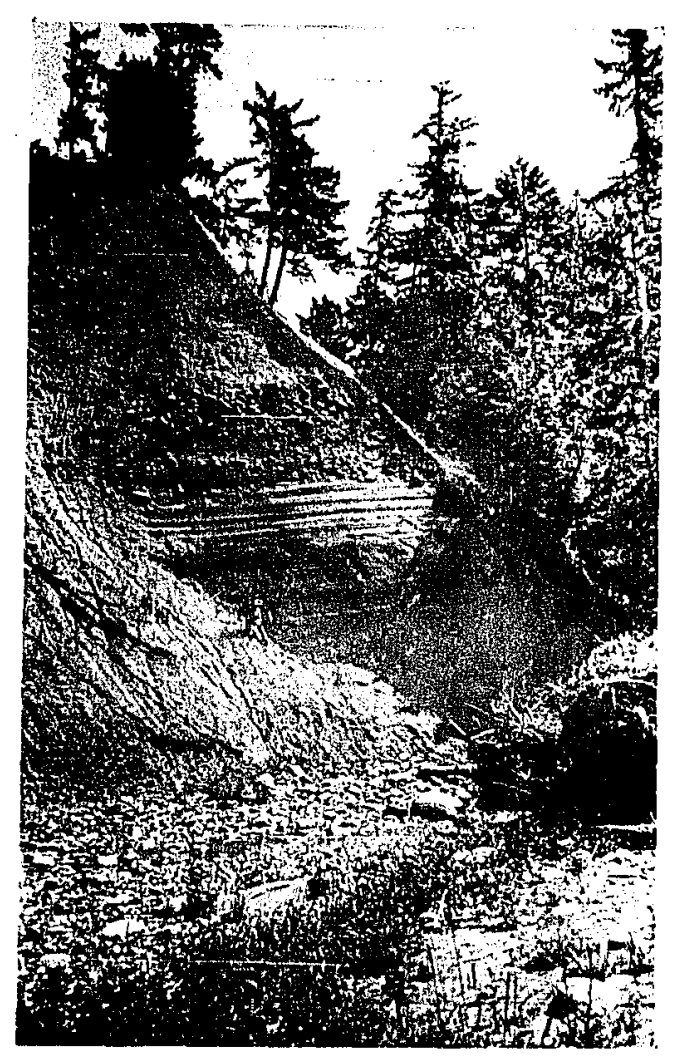

Figure 28. Gut bank on the northwest side of Englishman River two miles downstream from the Falls, showing stratified materials that are probably equivalent to the Quadra and Dashwood groups lying beneath tili. The exposed succession is outlined in the text. 
Company trestle over the south fork of Englishman Rjver is a 30-foot section of similar rusty sands and silts with numerous thin peaty partings that butts into an alnost vertical rock face and is covercd by 70 feet of till. The sub-till strata are exposed for only a few feet and certainly lens out within 200 feet. Sand and gravel rather than marine beds underlie the party beds in this locality. The peaty materials in both of these Englishman River localities consist of tiny woody Makes and probably are thoroughly cominuted driftwood.

\section{QUADRA SEDIMENTS OUTSIDE THE MAP-AREA}

Gravels, sands, and silts beneath till are present in many places in the Georgia depression. In the early reports dealing with the surficial deposits of the region, all such deposits were considered to belong to a single stratigraphic unj $t$, but recent investigations have revealed such sub-till deposits below the Dashwood group, in the Quadra group, in tine Semjamu group of Amstrong and Brown (1953), and forming glaciofluvial accumulations. wi thin the Vashon group. Nonetheless, as pointed out at the beginning of this chapter, many of the sub-till sands exposed in the Georgja depression are assocjated wh peaty materials and are otherwise jdentical to the Guadra sediments as here described, and on the basis on this li thologic simflarity the writer tentaijvely correlates them with his Quadra group. Included in this category are tine "type" Quadra deposits of Armstrong and Brown (1953) at Point Grey, and other deposits near Vancouver. Sands exposed in many places around the northern part of Georgia Stralt are also correlated wi th the Quadra group on this basis. These are principally found on Thormanby, Texada, Harwood, Savary, 
Hemando, Cortez, end Guadra Iolands (Dawson, 1887; Lehoy, 1908; MeConnel1, 1914). Simileir peet-bearing sands anä associated gravels on southem Vancouver Is]and at Victorja, Cordova Bay, Wowjchan Head, Jomes Island, and Cobble Hill are al:o tenteitively correlated. wi th the Cuadre group. These deposits are classifjed by clapp (1913, p. 110) as the Cordova sands and pleced in the fuyallup interglacial epoch.

\section{MODF OF ORIGIN OF THF GUADPA SEDIMENTS}

The basal peat-bearing beds of the cuadra group appear to have been formed in a swampy coastal lowland. The peats, which in part represent in place organjc srowth, record extengive shallow ponds or hidespread swanpy ground. The other soil profiles and the moss beds must have accumulated when the ground surface stood above water level, al though all. the soils are indjcative of nojst lowlend conditions. The well-sorted gravel, sand, and silt accompanying these swamp and lowland plant accumulatjons appear to have been formed in the same environment and therefore are either river channel and floodplin in deposits or shoreline deposits. Such shallow-water and terrestrial deposits resting on marine clay would logically be rapected to have accunuleted nong the see shore during gradual eneronce of the land from the sea. This inference seems to be coxrect on Denman Island where the basal silts of the Guadra group contain both casts of merine shells and incjpient sojlis, and at lhef Ureek where wadra silts and sands contrining peaty driftwood accumulatjons grade lateraliy into silts containing marine shells. On the other hand, except for the tro localities mentioned aove, eravels and silts of the peat-bearing unit have not yielded remains of marine organisins and hence 
these deposits probably accumulated in stream channels and floodplains extending back from the shoreline across the emerged sea-bottom plain. Sands of the Quadra group are believed to be remnents of a fluvial plain that once occupiea at least the northern part of the Georgia depression. The thick, ridespread sands are indicative of a large supply of sediment. Their horjiontel stratificetion wi th only small scale cross Iamination and the complete lack of thleker fore-set bedding show that the sands were formed as successlve shallow-water beds during an interval of rising base level rather than by outrard bujlding into deep water. Fluvial, and possibly glacial action nust have derived these sediments from the source materials and concentrated them in the Georgia basin; waves and currents in any lake or marine body in the Georgia depresalon, al though capable of redistributing sands sufplied by streams, vould be too weak and irregular to accumulate such extensive and uniform sands from bedrock or overburden. The environment of deposjtion is apparent only at Comox, where intercelation of peaty soll and leaf beas hith the sands suggests a river-plain envijonment. Elsewhere, the nature and distribution of sands, their stratification, and particularly thejr characteristic Ienticular cross lamination, coupled with the absence of marine fossils, lend support to thejr classification as river plain deposits but do not exclude the possibillty that sanas accumulated on beaches or in shallow lacustrine or marine water.

The top surface of the Guadre sands is erosjonal and their original extend and constructional form are not clearly apparent. In addition to making up large parts of the lowlands bordering the northern 
pert of Georgia Strejt, Quadra-type sands form the cores of isolated small islands within the Strajt and isolated patches on the offahore side of Texada and Denman Islands (see Figure 20). If erosion of the sands has not been great and their present distribution reflects their original extent, these jsolated patches must be ice-marginal deposits thet accumulated as large-scale kame terreces, or in extensive jee-contact ponds. But, if the Quadra sediments are ice contact ceposits, Elacial jce must have persisted from the Dashwood glacial invasion throughout ceposition of the stony clav of the Dashwood group, through the ensuing lowering of sea-level and accumulation of the basal quadra peaty beds, and during the steady rise of base level that accompanied deposition of the sands. Such persistence of remnant jce seems most unlikely and thus the suggestion that the sands were formed as jcecontact deposits is rejected. Alternatively, the sands of the quadra group may be remnants of deposjts that formerly were much nore extensive -_ej ther a serjeg of large deltas that formerly occupjed the marginal parts of the Georgia depression or a fluvial (estuarine?) plain that filled across the full width of at least the northern part of the depression. Mineral end rock grains composing the sands of separate deltas would vary in composition from delta to delta with the local beärock. Deposits of streams issulng from the Coast Range and from the head of Georgia Straj t would consist dominantly of granodjorite detritus, Wherees deposits of streams bordering Vancouver Island would be derived primarily from basic volcanic rocks, sandstone, and shale, and only secondarily from granitic materials. The constj tuent sand grains in a coalescent fluvial plain, on the other hand, would be more uniform 
because of interningling of sands from the various sources. The cuentj ty of ernitic detritus brought into the Gecrgis depression by streans from the Coast Range would far exceed the detritus of voleanjc and sedimentary rocks fron Voncouver Islanc, anci if fluvial defosits extended across the full width of the basin, sand-size materigl right up to the Vancouver Island sjde of the basin would probably consist principally of the mineral components of eranodiorjte. That the cuadre sants were, inceed, lajd dorn in a fluviel plain that extended across the Georgia depression is suggested by their "granodiorite composition" within the mapped part of the vancouver Island coestel. plein, perticularly when contrested with the dominance of volcanjc and metasedimentery pebbles in associated eravels that, presumably, are representative of locelly derived materials.

\section{SUB-VASHON EROSION SURFACE}

The Vashon group is separated from the fuadra sedjinents by a prominent erosional discordance. The cross-cutting nature of the till-sand contact is clearly evident in the stretigraphic crosssection of the Dashwood sea cliff (Plate IA) and in the photographs of the northeast end of the comox sea cliff (Fjgure 29). In the parts of the coastel lorland where the Vashon and other deposits sup-rposed upon the Guadra sends form s. thin veneer of relatively uniform thickness, hills and valleys of the present surface reflect the VashonQuadra erosion surface. In other places (for instance, adjacent to Li ttle (ualicum River) valleys or depressions in the erosion surface 100 feet or more in depth have been filled with till and leter deposits. The sub-Veshon erosion surface in and adjoining the map-area 

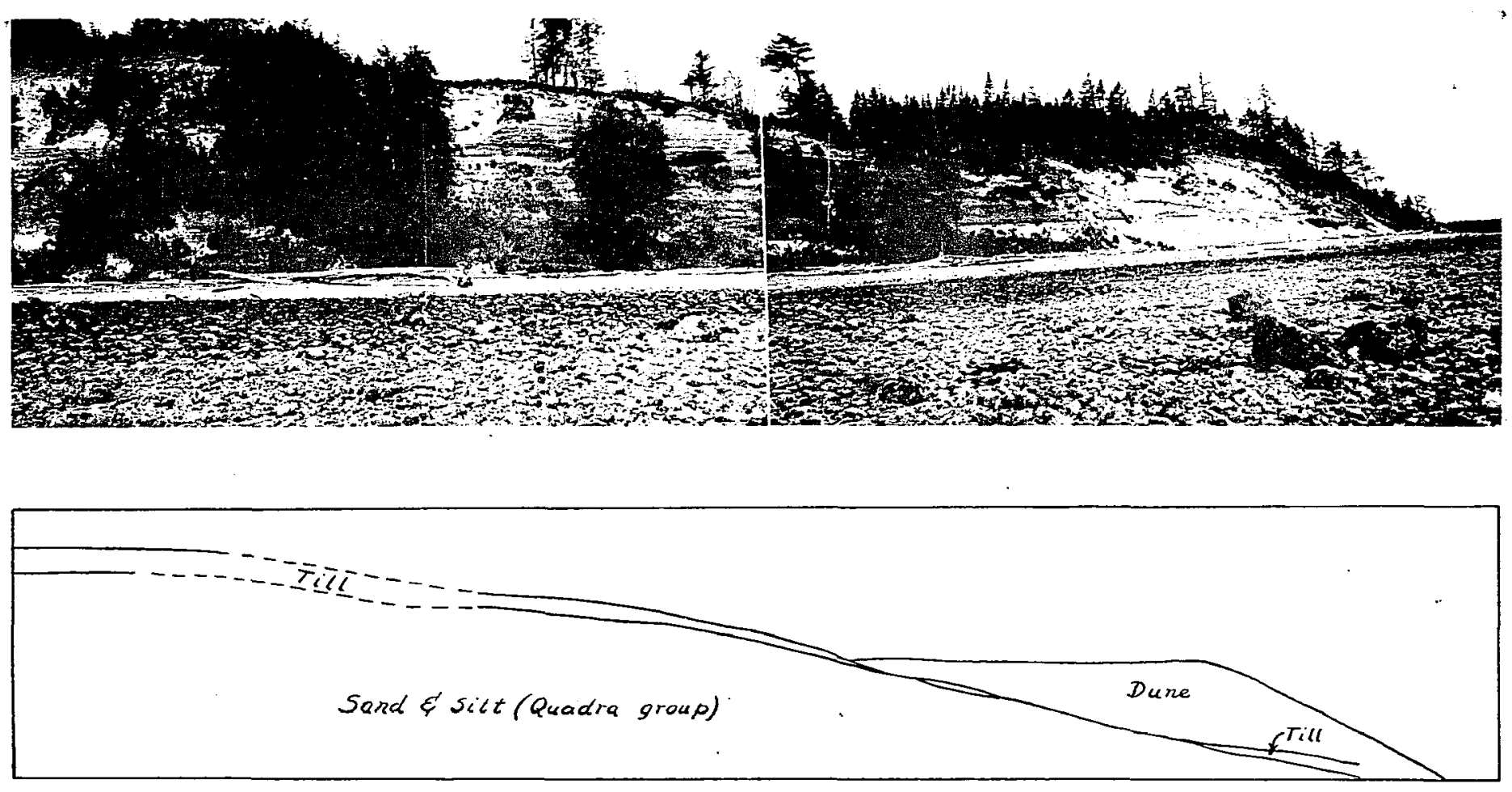

Figure 29. Northeast end of the Comox sea cliff shoving till of the Vashon group resting on successively lover beds of the Quacra group from left to ritht. The cliff is about 100 feet high at the $I \in f t$ end of the photograph. The diagram shovs positions of the matarials in the photozraph. 
provides little information about the eroding agent. In the Lovier H'raser Valley, however, the sub-Vashon surface is marked by two broed winding valleys, 1 to 2 milee across, now occupi ea by the Nicomekl and Serpentine Rivers. The fluviul orj gin of these valleys is clearly apuarent in theix present, surface topograyhy, despite glacial erosion and the cover of till and marine materials up to 300 feet in thickness (see fimstrong and Brom, 1953, maps). As outlined above, the cuadra deposits were fomerly very extensive. Whether, $a . s$ believed by the writer, they were formerly continuous across the northern part of the Georgia depression, or whether they nerely formed a series of large deltaic deposits deposits around the basin margin, a very great anount of naterial must have been removed since they were devosj ted. In the absence of Iarre acale erosion since accumulfition of the $V_{\text {ashon }}$ deposits, most of this removal must be represented in the erosion surface beneath the Vashon group till. The presence of 20 to 50 per cent of sandsize inateriel in tills of the Vashon group where they rest upon Guadra sand indicates substantial erosion of the cuadra seainents by the glaciol jce, but the cuantity of sand in the Vasion roup and derived materials (assuming that exposed thjcknesses within the map-aree ore representative) is much less then the mount of Guadra sand that is missing. The writer therefore, infers that the fluvial dissection beneath the Vashon till that is evident in the Lower Fraser Valley was general throughout the northerm Georgia depression and was responsible for removel of much of the missing Guadra sediments. The base level to which the streans were graded probably was below the present sea-level al though because of subsequent 
glacial deepening, it may have been considerably above the base of the Vashon till.

MAGNITUDE AND AGE OF THE NON-GLACIAL INTERVAL

In the northern part of the Georgia depression, a nonglacial interval clearly intervened between deposition of the Dashwood and the Vashon glactal matertal $s^{5}$ but whether it was of interglacial proportions or merely interstadial is open to some question. As suggested below, it may have been an interglacial and, if so, probably is correlative with the Sangamon.

Fossil materials in the Quadra sediments (wood, soils, marine shells) are suggestive of a cooler climate than the present one and possibly like that of the Gulf of Alaska. They are indicative of conditions that would be expected to prevail during a short interstadial, but, as they are found in only the lower intertill strata, they may not be representative of the whole interval. Changes in the relative positions of land and sea provide an additional indication of the duration of the interval. Transition from the Dashwood marine stony clay (highest correlative deposits 250 feet above sea-level) to the basal peaty beds of the Quadra group reflects a sea-level lowering of more than 250 feet. Accumulation of the succeeding horizontally

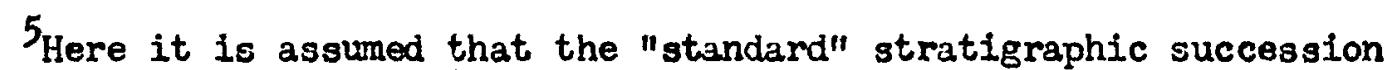
of the map-area (Chapter 3) is essentially complete and, therefore, that a single non-glacial interval separated the Dashwood and Vashon glaciations. It should be noted that this assumption is at variance with the interpretation of the stratigraphy of the Lower Fraser Valley presented by Armstrong and Brown (1953, Stratigraphic Table). 
stratified Quadra sands in thicknesses exceeding 300 fest must have accompanted a base level (sea-level?) rise rather than merely changes In stream loading and discharge. Then the sub-Jashon dissection of these deposits, in so far as it was fluvial, must have resulted from a lowering of base level (sea-level?). The rise of base level prom bably was greater than 300 feet and may have been more than 500 feet; the lowering probably was somewhat greater than the rise. Sea-level changes of the order of those listed above have taken place in the area during the postmglacial interval since accumulation of the Vashon deposits and consequently the intertill elevation changes may well have taken place during a short interstadial interval. They probably are the result of isostatic and diastrophic movements of the land rather than eustatic changes of sea-level.

Further information regarding the magnitude of the nonglacial interval is provided by the erosion that intervened between deposition of the Quadra sediments and the Vashon till. The amount of fluvial erosion attributed to this interval is based upon inferences of the original extent of the Quadra sands and of the quantity of material removed later by the glacial ice that deposited the Vashon group. As outlined above, the writer infers that the quantity of material removed by the sub-Vashon fluvial erosion was very great. In the northern part of the Georgia depression it may have been of the order of half the present volume of the basin below an elevation of 300 feet. Fluvial erosion of this amount of material on essentially level ground almost certainly would require an interval of interglacial rather than interstadial proportions. 
Wood and peat from the basal beds of the Quadra group at Dashwood (exposure 28, cross-section, P.Late IA) have been dated by the radiocarbon method at the Lamont Laboratcries as having formed more than 30,000 years ago. If the Wisconsin age is assumed to have begun with accumulation of the Farmdale deposits, which have been dated by the radiocarbon method as about 25,000 years old, then the Quadra group is pre-Wisconsin. Logically, the Vashor group, which was deposited during the last glaciation of the region, must be Wisconsin and the few available radiocarbon datings confirm this conclusion. For Instance Broeker and KuIp, (1955) report: "The retreat of the Vashon ice sheet from Stillwater, Washington is shown to have occurred approximately 12,000 years ago." Therefore, a Sangamon age is logical for the non-glacial (interglacial?) interval that preceded deposition of the Vashon group and that included the period of deposition of the Quadra group. 


\section{CHAPTER 7}

THE VASHON GROUP AND THE LAST REGIONAL GLACIATION DEFINITION

The name Vashon group is applied in this report to the deposits of the last regional glaciation. The "type" Vashon deposits of this area are found on the coastal lowland and are defined in terms of the "standard" stratigraphic succession as comprising till and related glacial materials that overlie the Quadra group. The till forms the ground moraine of the coastal lowland. The varied tills comprising the ground moraine of the rest of the area have yielded no evidence of large differences in age or of distinct stages of glacial advance or retreat. They are arbitrarily considered to belong to a single glacial invasion and are assigned to the Vashon group---along with the attendant glaciofluvial and glaciomarine deposits. In practice, during mapping, 27 glacial deposits of the area were included in the Vashon group except those assignable to the Dashwood group on account of their position beneath Quadra sediments, and those on the higher parts of the coastal lowland northwest of Thames Creek that lie beneath thick gravels and sands beneath a younger till. Therefore, some of the tills assigned to the Vashon group, particularly in eroded areas, may belong to the Dashwood group or to old and as yet unrecognized glacial invasions.

The name Vashon was first used geologically by Willis (1898, p. 128) for the uppermost till of the Puget lowland and for the time interval of the last regional glaciation of that area. It has been applied in the same sense to similar deposits on Vancouver Island by 
C. H. Clapp (1913, 1914, 1917) and around the city of Vancouver by E. M. J. Burwash (1918) and W. A. Johnston (1923). It has gained general acceptance by geologists, pedologists, and civil engineers in this part of British Columbia. The writer, therefore, has retained the name Vashon instead of introducing a new unfamiliar term, although he does not intend to imply that correlation with the Puget Sound deposits is, as yet, anything more than a guess.

\section{ADVANCE SUMMARY}

Ground moraine deposits of the Vashon group are found throughout the coastal lowland and Alberni Valley and, in addition, form local pockets and thin veneers in mountain valleys and on mountain slopes. In the coastal lowland, the ground moraine typically rests upon quadra sand and is characterized by very sandy texture. Except near Englishman River, the component materials have been derived from sources within the Georgia depression rather than in the Vancouver Island mountains. Tills on mountain slopes and in mountain valleys are mostly more clayey than the lowland tills but a few are extremely sandy and stony. The mountain tills consist dominantly of detritus of the basic volcanic country rocks. The ground moraine of the eastern part of Alberni Valley is loamy to clayey, but a belt of granodiorite-rich till along the western side of the valley is less clayey and more sandy. Small, isolated ice-contact deposits of gravel and sand also belong in the Vashon group. Most of these appear to have accumulated in streams along glacial margins, but some are deposits of streams bordered on both sides by ice and a few are shore deposits of ice-dammed lakes. 
Most of them are classified as kames, kame fields, and kame terraces, but a few are eskers, ice-contact alluvial fans, and ice-contact deltas. An extensive landslide deposit in Alberni Valley is also interpreted as an ice-contact phenomenon. Stony clays in Alberni Valley and the Georgia depression appear to represent a transition from glacial to marine conditions and are assigned to the Vashon group, although in mapping they are not separable from the marine deposits of the Gapilano group.

During the climax of the glaciation associated with the Vashon group, an ice sheet covered the entire map-area except the summit of Mount Arrowsmith, and flowed south to southwest from the Georgia depression across the Vancouver Island mountains. After the ice level had receded below the crest of Beaufort Range, tongues of ice contimed to flow southwest in the passes through the mountains at Horne Lake and Cameron Iake and probably merged with a southeastflowing glacier in Alberni Valley. The Alberni Valley ice, in turn, was fed by glacial tongues flowing eastward out of tributary valleys and emanating from an ice cap on the uplands of Forbidden Plateau northwest of the map-area. During deglaciation, the margin of the Alberni Valley glacier withdrew northwestward up the valley and the tributary glaciers receded more or less contemporaneously into their respective valleys. The retreating ice margins in the bottom of Alberni Valley appear to have been bordered in part by marine water standing 300 feet above present sea-level. Ice in the valleys of Beaufort Range apparently stagnated as the ice level fell below the 
crests of the intervening ridges. Streams and small lakes bordering the stagnant ice left narrow terraces along the valley walls, and mountainside torrents built alluvial fans against the ice.

A southeast-flowing glacial mass occupied the Georgia depression. Ice-contact deposits along the southern edge of the depression record progressive lowering of the surface of this ice and outline streams that flowed southeastward along and adjacent to the lateral edge of the ice. Delta-like deposits of ice marginal streams near the mouths of the Cameron Lake and Horne Lake Valleys provice evidence that ice terminated in marine water standing between 450 and 500 feet above the present sea-level and that the glacier terminus receded progressively northwestward. An active glacier flowed down Englishman River Valley to merge with the Strait of Georgia ice and was fed by cirque glaciers flanking Mount Arrowsmith. Cirques on the Beaufort Range, however, have not been occupied by active. glaciers since the climax of the last glaciation. GROUND MORAINE DEPOSITS OF THE VASHON GROUP The tills of Vancouver Island, as of ary mountainous area, are extremely variable in texture, thickness, and surface topography, Those within the map-area that are assigned to the Vashon group are mostly concrete-like mixtures of stones, sand, silt, and clay that reflect, in texture and rock constituents, the underlying and nearby unconsolidated deposits and bedrock. Some of the most gravelly tills, occurring mainly in the mountain valleys, are looser in consistency and are similar to poorly sorted fluvial gravels. Covering the till in parts of the area is a veneer of loose gravelly material, 
averaging 3 feet in thickness, that has the appearance of superiaeial till (Flint, 1949, F. III). Much of this meterial, however, has been demonstrated to be a las grevel concentrated from the underlyine till by raves and streams, and some is merely the result of aurface disaggregation of the coherent till.

In the lowlands and valley bottoms the ground-moraine depposits are relatively continuous and locally exceed 100 feet in thickness but in the mountains and hilly areas they are Eenerally thin and discontinuous. Much of the morainic material presents no distinctive topography but merely fills in irregulerities in the surface of the underlyjng belrock or surficial naterials. Nonetheless, fairly extensive areas of rolling and humnocky ground morajne occur on the coastal lowland and in Albemi Valley, and an area of arumlinojd ridges end furrows cccupies much of the northwestem part of Albermi Valley. Fnd morajnes appear to be entirely absent.

\section{"Type" Vashon Tilis}

The till forming the ground morajne of the coastal lowland between Englishman River and Chef Creek rests in large part upon sand of the Guadra group, and thus can be assigned to the Vashon group on the basis of its stratigraphic position. This till. is characterized by a sandy-losm texture (most other tills of the aree have loam to clay-loam texture) and by its large content of fine sand. It is a pale grey, hard, compact material that is strone enough to stand indefinitely as vertical faces in uncribbed wells and that, not infrenuently, requires blasing during excavation. In some places, the till fills irregularities in the eroded surfece of the underlying Quadra sediments, whereas in others $j t$ mantles the underlying topography as a sheet of relatively uniform thiclness. The constructional 
groundmoraine topography developed on this till consists of irregularly distributed smooth rounded hills a few hundred feet across and generally less than 30 feet high, but this topography has been subdued in many places, and even obliterated in a few places by marine erosion and deposition. The till averages a few feet to a few tens of feet in thickness, but locally, as a result of marine erosion, it is represented only by a lag concentrate of large stones. The maximum recorded thickness of till overlying Quadra sand is 100 feet, but at the east end of the Dashwood sea cliff, where the entire Quadra group has been removed by erosion, the Vashon till is more than 200 feet in thickness.

Mechanical analyses of eleven tills of the Vashon group that rest upon Quadra sand are illustrated in histograms (Figure 30) and as sand-silt-clay ratios (Figure 31). The sand-silt-clay matrices of most of these tills are sandy loams but a few are loams. The six samples whose coarse fractions have been analysed contain 18 to 42 per cent of gravel and boulders. Each of the grain-size histograms has a modal peak in the fine sand size very close to the median grain size of the typical underlying sands of the Quadra group. The average modal grain size of the eleven analysed tills is 0.20 $\mathrm{mm}$ and the average median grain size of six typical Quadra sands is $0.16 \mathrm{~mm}$. Clearly, the sand in these tills was derived by the glacial ice from the Quadra sand over which it passed. The writer hoped that the high sand content of the "type" Vashon tills would provide a basis for their distinction from the older tills of the Dashwood group, but, as already indicated, some of the tills of the 

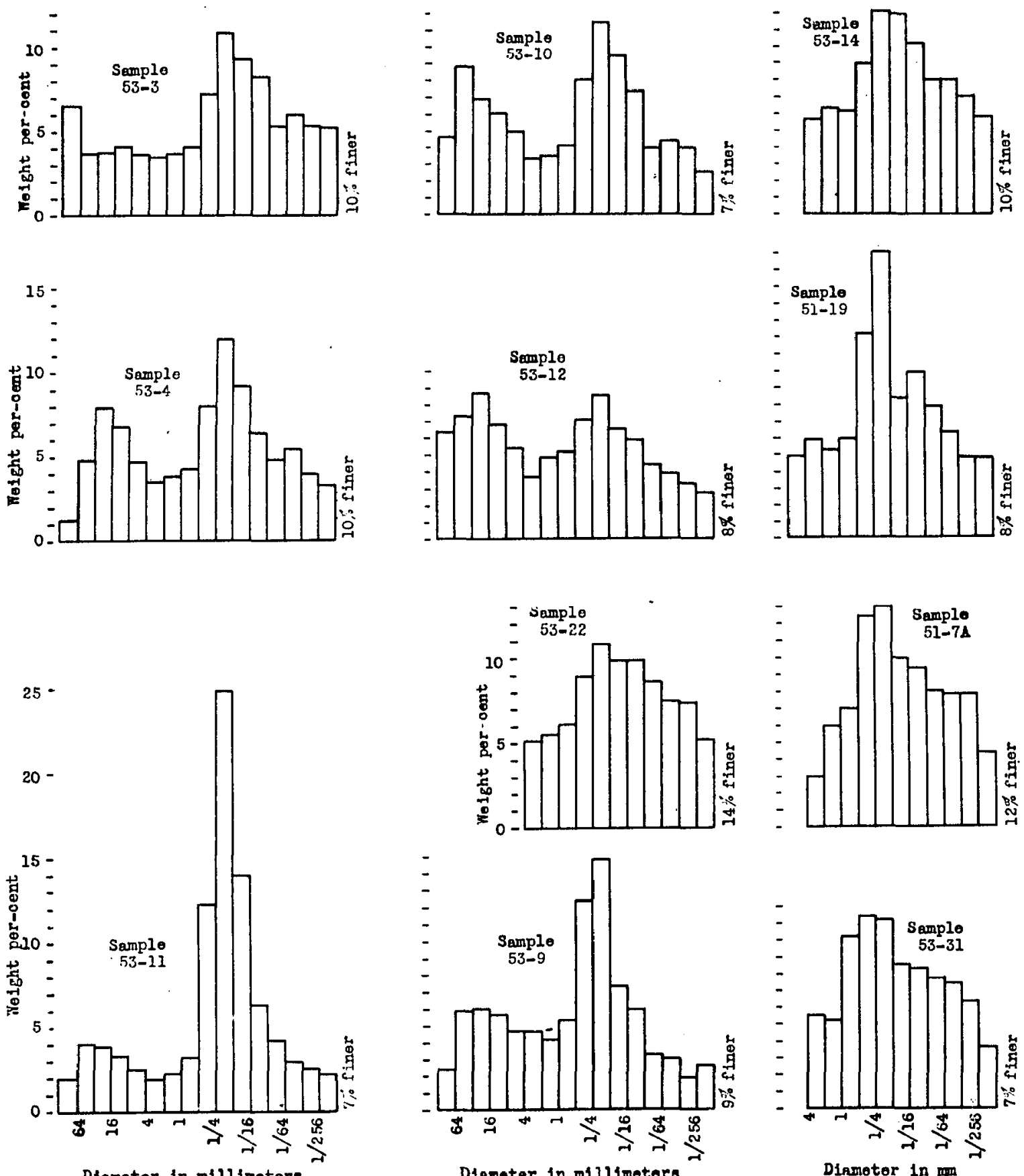

Diamotor in millimoter:

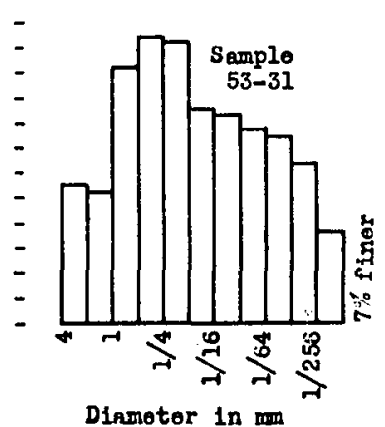

Figure 30. Grain-size distribution of "type" tills of the Fashon group. These t11ls rest upon gand of the guadra proup and contain an abundance of material of the same sise range an this and of the Quadra group and contain an abund ance of material of the same sise range as the sand, as indloated by the peak on each graph at $1 / 4$ to $1 / 8 \mathrm{~mm}$. Samplos $53-3,4,11$ r.om trood; 53-10 from Frenoh Crook; 53-12,22 from near tho highay oast or noar Chof Croak. 


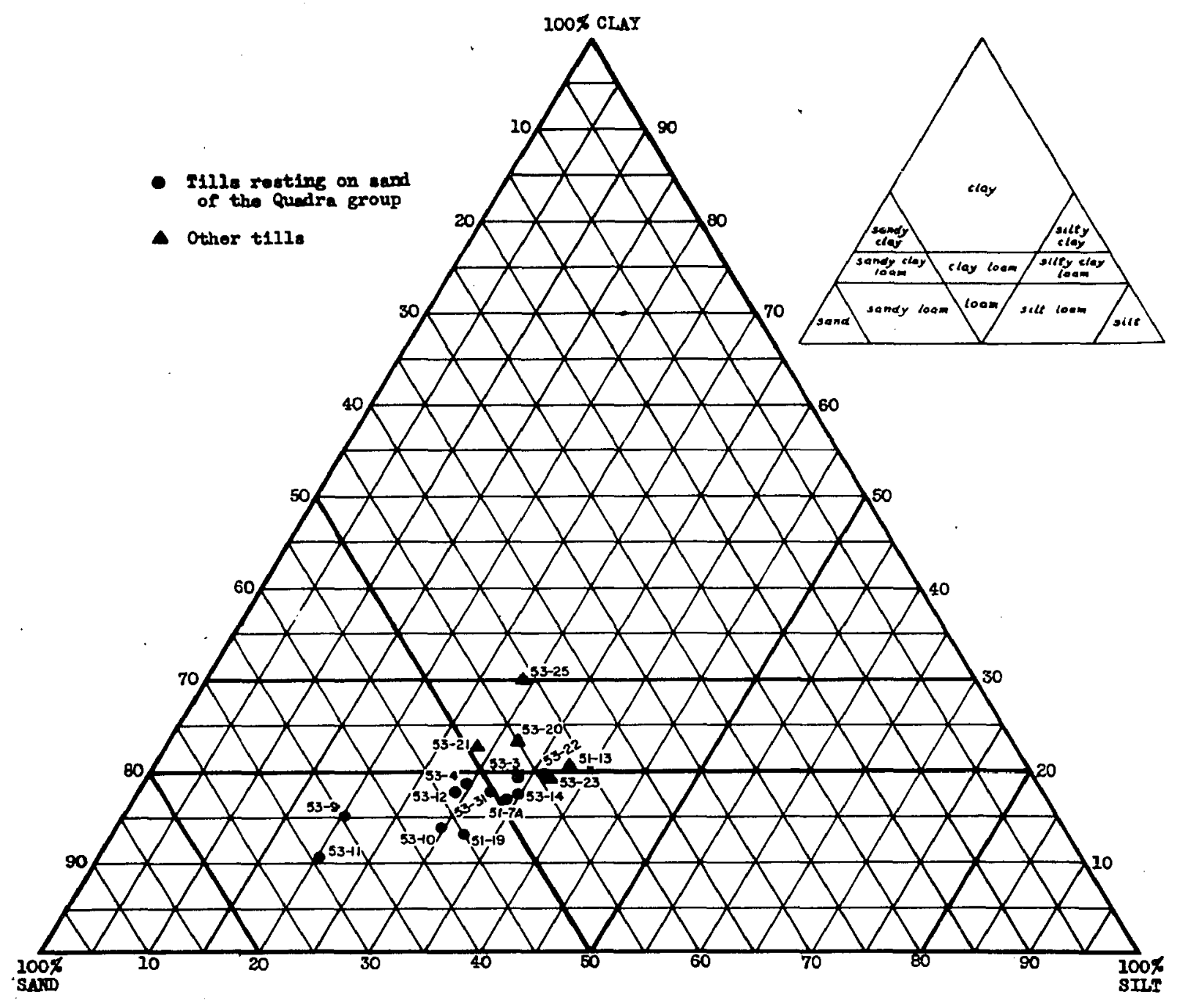

Figure 31. Mochanioal composition of the minus $2 \mathrm{~mm}$ Praotion of Vashon group tills of the cosstal lowland. Sand, silt, and olay are definod in terms of the Wentworth erade soalo. 


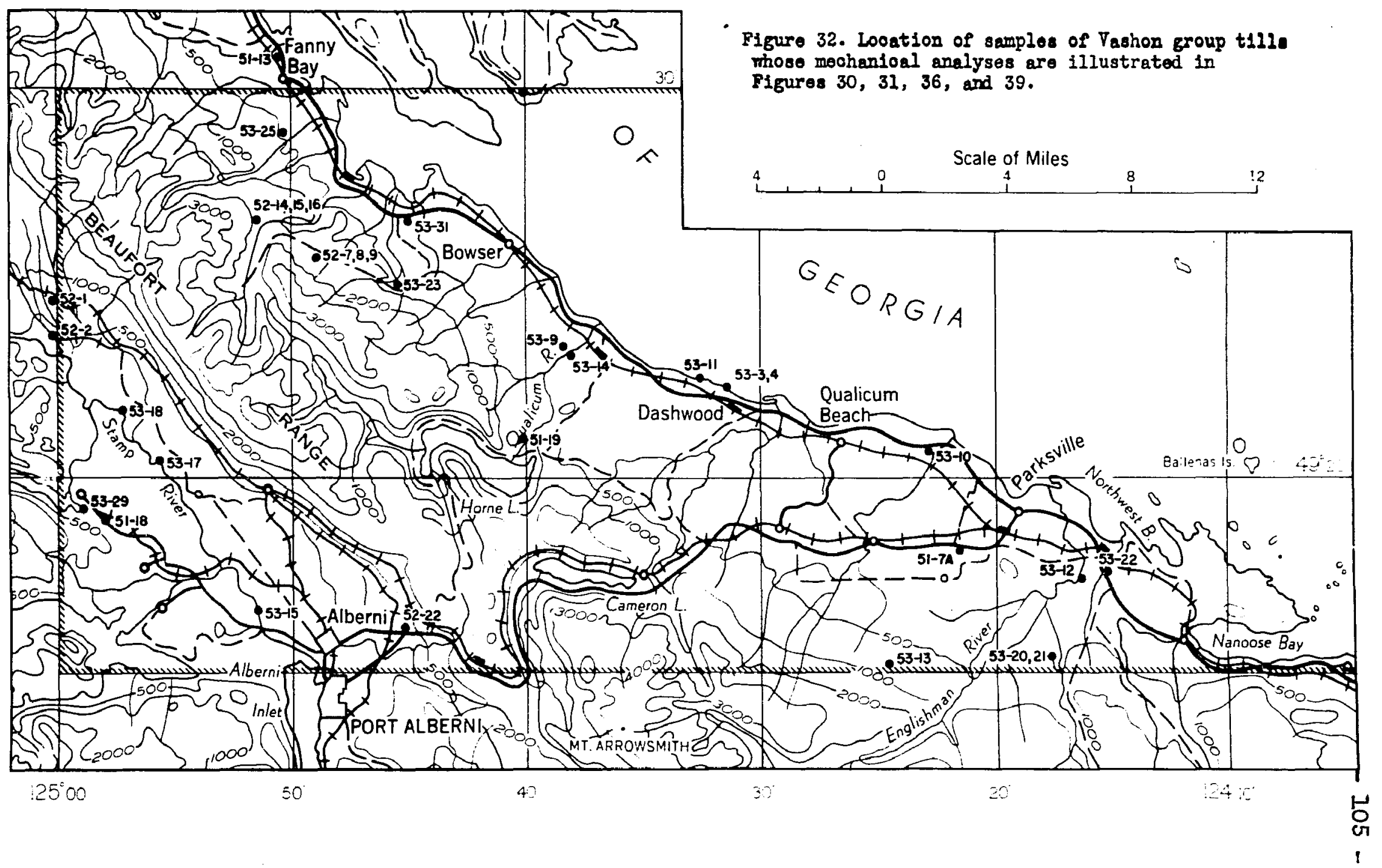


Dashwood group contain a similar concentration of fine sand. The "type" tills of the Vashon group also have a secondary mode in the pebble size range and a deficiency of material 2 to $8 \mathrm{~mm}$ in diameter. Pettijohn (1949, p. 40-45) has assembled information showing that a deficiency of material in this sjze range is encountered in many sediments and particularly in fluvial materials. This bimodal grain-size distribution is not characteristic of any other tills of the area and its presence in these "type" tills of the Vashon group may reflect the fluvial nature of the Quadra group materials incorporated in them.

Stones in the "type" tills of the Vashon group, are, for the most part sub-angular to sub-rounded as if derived from waterlaid gravel rather than directly from bedrock. The pebble-size stones are, on the average, about 85 per cent volcanic, II per cent granitoid, and 4 per cent sandstone and shale (see Table II). The available pebble counts of the "type" tills of the Vashon group show no consistent variation throughout the part of the coastal lowIand in which they occur and bear no relation to either the underlying bedrock (mostly shale) or bedrock changes in adjoining parts of the Beaufort Range. Probably, the stones have been derived from a variety of sources within the northern part of the Georgia depression.

Fabric orientations of nine Vashon tills that overlie Quadra sand form two disperse groups, one trending north to northeast and the other east to southeast (see Figures 15 and 50). This distribution may in ean that the tills were deposited by two distinct glacial movemenț, one southeast parallel to the Georgia depression 
TABLE II

PEBBLE COUNTS OF TILIS OF THE VASHON GROUP THAT REST ON QUADRA SAND

\begin{tabular}{|c|c|c|c|c|c|}
\hline \multirow[b]{2}{*}{ Location } & \multirow[b]{2}{*}{$\begin{array}{l}\text { Number } \\
\text { of } \\
\text { Pebbles }\end{array}$} & \multicolumn{3}{|c|}{ Percentage of rock types } & \multirow[b]{2}{*}{ Others } \\
\hline & & Volcanic & Granitoid & $\begin{array}{c}\text { Sandstone } \\
\text { shale }\end{array}$ & \\
\hline \begin{tabular}{|l} 
Dashwood, \\
exposure 20
\end{tabular} & $\begin{array}{r}105 \\
97\end{array}$ & $\begin{array}{l}91 \\
93\end{array}$ & $\begin{array}{l}7 \\
6\end{array}$ & 1 ss & 1 Iimestone, 1 ? \\
\hline $\begin{array}{l}\text { Dashwood, } \\
\text { exposure } 16\end{array}$ & $\begin{array}{l}106 \\
105\end{array}$ & $\begin{array}{l}82 \\
83\end{array}$ & $\begin{array}{l}16 \\
16\end{array}$ & 1 ss & $\begin{array}{l}1 \text { argillite } \\
1 ?\end{array}$ \\
\hline Qualicum $R_{\text {. }}$ & 100 & 90 & 7 & $3 \mathbf{s s}$ & \\
\hline Mile Creek & 118 & 73 & 14 & $12 \mathrm{ss}, 1 \mathrm{sh}$ & 1 quartz \\
\hline Deep Bay $\mathrm{Rd}_{\text {. }}$ & 105 & 81 & 12 & $5 \mathrm{ss}, 2 \mathrm{sh}$ & \\
\hline Chef Creek & $\begin{array}{r}100 \\
94\end{array}$ & $\begin{array}{l}85 \\
82\end{array}$ & $\begin{array}{l}10 \\
14\end{array}$ & $\begin{array}{ll}5 & 83 \\
4 & 33\end{array}$ & 1 quartz \\
\hline $\begin{array}{l}\text { Arrowsmith } \\
\text { Farms }\end{array}$ & 96 & 91 & 8 & & 1 quartzite \\
\hline $\begin{array}{l}\text { French Creek: } \\
\text { at highway } \\
\text { at power line }\end{array}$ & $\begin{array}{l}102 \\
120\end{array}$ & $\begin{array}{l}84 \\
83\end{array}$ & $\begin{array}{l}14 \\
12\end{array}$ & $\begin{array}{ll}1 & \mathrm{ss} \\
4 & \mathrm{ss}\end{array}$ & 1 quartz \\
\hline NW Errington & 100 & 83 & 14 & $3 \mathrm{ss}$ & \\
\hline
\end{tabular}


and the other south-southwest across the depression. Alternatively, both sets of fabrics may have been formed by ice moving in one of the preferred directions---one set parallel to the ice movement and the other transverse to it. Holmes' study of fill fabric in New York (Holmes, 1947) revealed that transverse fabrics are much less numerous than those with preferred orientation parallel to the glacial movement. Therefore, the approximately equal numbers of the Vashon till fabrics oriented in each of the two directions may be an indication that they indeed record two ice movements. The "type" Vashon till seems to comprise a single sheet. Sand and gravel beds occur locally within the till but everywhere seem to be lenses of local extent. Pebble counts above and below such partings at French Creek and at two places on the Dashwood sea cliff are almost identical and till fabrics above and below the partings at the two Dashwood localities are similar in orientation (see Figure 33). Typically, Vashon till rests directly upon the eroded surface of undisturbed Quadra sand but, in some places, the till is separated from the undisturbed sand by a few inches to a few feet of sand containing till lenses and in which the original stratification has been faulted, brecciated, or completely destroyed (Bigure 34). The most sandy "type" Vashon tills (e.g. Dashwood cross-section, exposures 15 to 17, Plate IA), which characteristically contain lenses and beds of sand and are locally scarcely distinguishable from unstratified sand, seem to be closely akin to these till-sand contact breccias. 

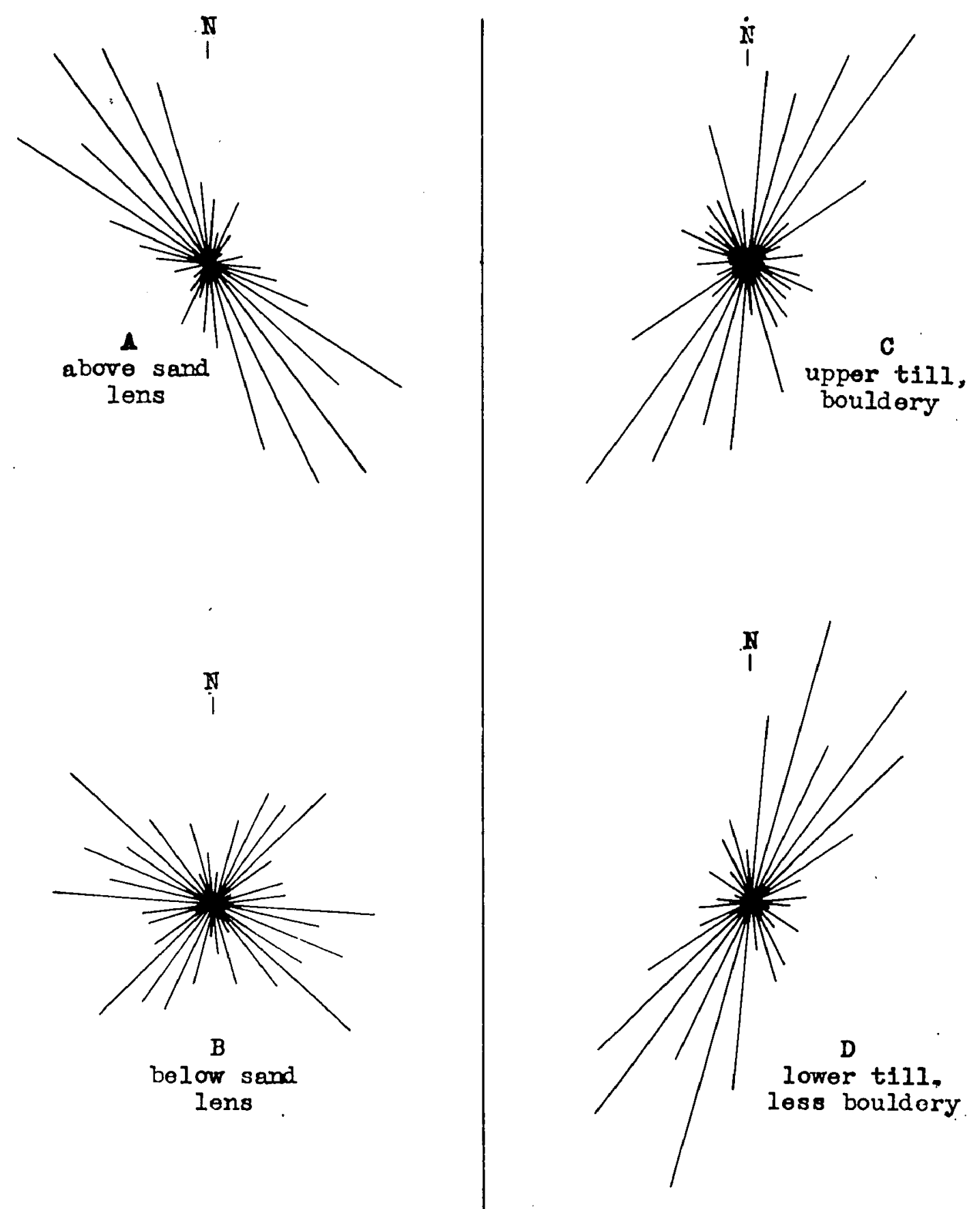

Figure 33. Long axis orientation of pobbles in tills of the Vashon group. $\triangle$ and $B$ at exposure 16, Dashwood sea oliff; $C$ and D South. Englishman River. Each diagram represents 100 pebbles. I per oent equals 0.2 inches. 


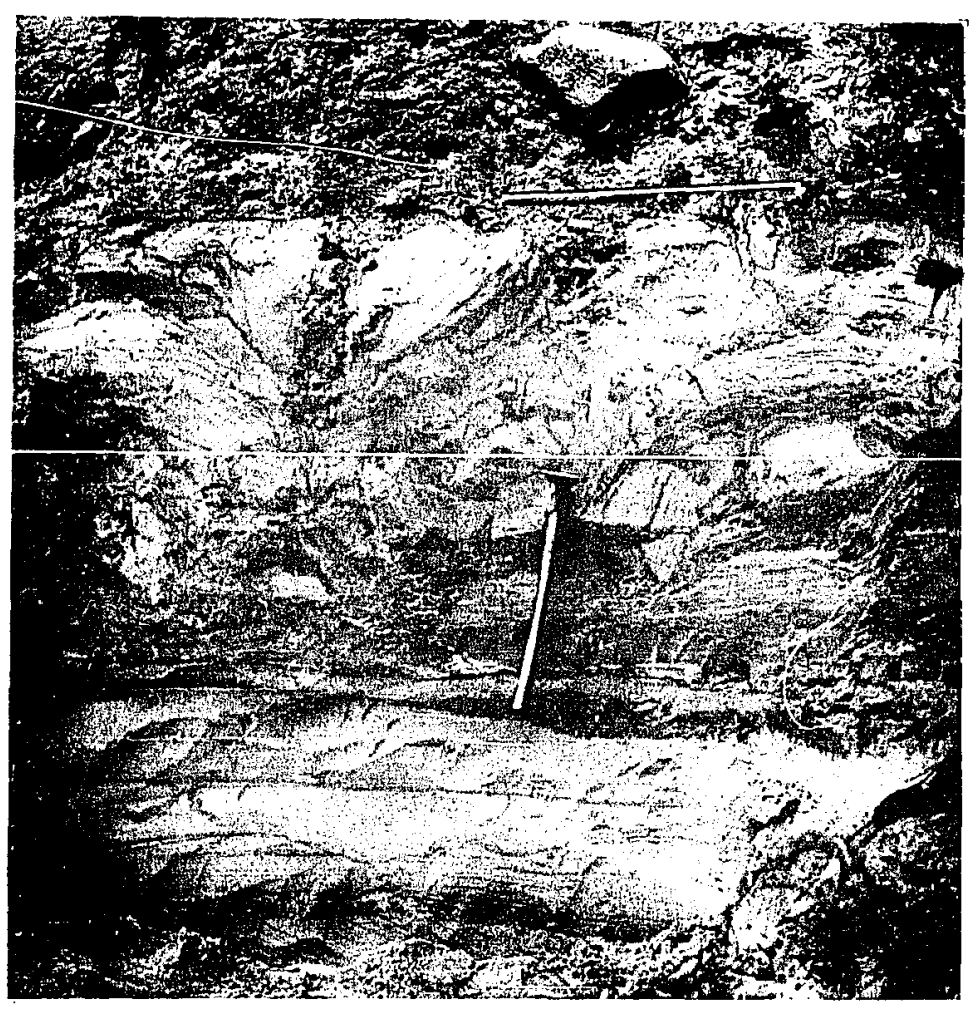

Figure 34. Sheared and brecciated sand lying between undisturbed sand of the Quadra group (below pick handle) and till of the Vashon group (above tape measure). Rough areas in the disturbed zone are lenses of till-like material. This exposure occurs in a pit adjoining the Island Highway at Craig Creok.

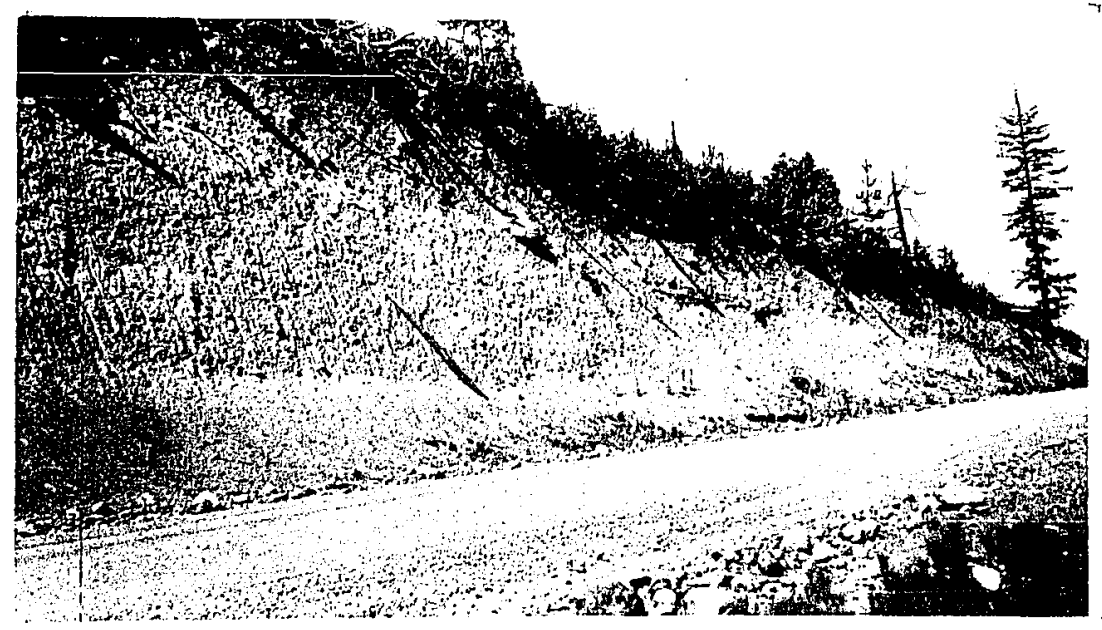

Figure 35. Road cut, South Englishman River, showing 10 feet of bouldery till resting upon less bouldery till. The two tills are separated by a sand parting. 


\section{Other Tills of the Coastal Lowland}

Tills around Nanoose Bay and Englishman River rest in part upon shale, sandstone, and conglomerate of the Nanaimo group, in part upon basement rocks, and in part upon sand of the Quadra group. They are texturally similar to the tills described above but typically contain a slightly higher percentage of both gravel and clay (see Figure 31). Most contain a few per cent of chert and quartzite pebbles derived from conglomerates of the Nanaimo group and from the basement rock's near Nanoose. Tills close to the mountain front in this part of the area contain stones derived from the granodiorite body to the south and west. Thus pebble counts (Figure 50) reveal that tills close to the mountains contain 20 to 60 per cent of granitoid stones whereas those nearer to the coast average about 11 per cent of granitoid stones. The tills near the coast, however, are overlain by a gravel veneer containing more than twice as many granodiorite pebbles. This gravel is believed to be a lag concentrate of stones from the uppermost part of the till and, indeed, the same high percentage of grandiorite pebbles was found in the uppermost part of the till in a few places. The high granodiorite content of the surface material is suggestive of a late, northeastward glacial movement down Englishman River Valley contrasting with the southeast and southwest movements associated with most other tills of the coastal lowland. A deep road cut where the Northwest Bay logging road climbs up the west bank of South Englishman River exposes about 10 feet of bouldery till separated from an underiying 
less bouldery till by a sandy parting (see Figure 35). Both tills are rich in granodiorite stones and both have well-oriented fabrics trending north-northeast (Figure 33); hence, both must have been deposited by ice moving northeastward out of Englishman River Valley.

Vashon tills of the coastal lowland in the northwestern part of the map-area (west of Chef Creek) lie in part upon gravel and sand, in part upon sandstone and shale of the Nanaimo group, and in part upon the basement volcanic rocks. Those resting upon volcanic rocks occur on the high bench extending west from the head of Chef Creek and are closely akin to the mountain tills to be discussed in the next section. Iying upon the thick gravel and sand that occupies much of the inland part of the coastal lowland between Thames Creek and Cowie Creek is a brown oxidized till a few inches to a few feet in thickness. This till is softer than the "type" Vashon till and has a loam to clay-loam matrix (see Figure 31 , samples $53-23,53-25)$. Grain-size histograms of the minus $4 \mathrm{~mm}$ fraction of the two analysed samples reveal an almost complete lack of sorting, although, in many places, the till appears to contain a concentration of pebble-size material. The tills in this northwestern part of the coastal lowland that lie upon sandstone and shale are similar in colour and consistency to those described above (see Figure 31, sample 51 - 13). The tills in the northwest part of the:map-area contain a slightly larger number of granitic pebbles than the "type" Vashon tills to the southwest 
(average 13 per cent granitic pebbles as opposed to 11 per cent in the "type" tills.) Northwest of the map-area the conient of granitic pebbles increases rapidly to 18 per cent at Fanny Bay and to 27 per cent at Union Bay, and the muber and size of granitic boulders littering the till surface increased proportionately. Many of these granitic stones consist of distinctive porphyritic granodiorite occurring in the small plutons of Wolf Lake and west of Bevan near Courtenay. Thus, both the nature of the granitic stones in the tills and their change in concentration record glacial movement from northwest to southeast along the Georgia depression. Three till fabric analyses of tills from this northwestern part of the map-area also trend southeast.

\section{Mountain and Valley Tills}

Morainic deposits of the mountainous parts of the area range from isolated patches a few inches in thickness to extensive valley fillings a hundred feet or more in thickness, and from very stony, light-textured till to heavy-textured, sticky boulder clay. For the most part, they occur in depressions and valley bottoms and on the lower, less steep parts of mountain slopes. They are not marked by any distinctive constructional topography and are extensively dissected. The morainic materials are texturally very similar to the widespread colluvial and alluvial fan deposits of the mountain slopes and valleys, and, in many places, their distinction rests solely upon identification of their constructional topography --which may, in turn, have been obliterated by dissection or 
concealed by the forest. Mapping is further complicated by intermingling of these hardly distinguishable deposits.

Most tills of the mountainous parts of the area are stony clay loams but some, distinctly lighter in texture, are very stony sandy loams (see Figure 36). The surprisingly high silt and clay content of the typical clay-loam tills (e.g. samples 52 - 8, 52 15, Figure 36) is probably attributable to their derivation almost exclusively from aphanitic volcanic rocks. The tills that contain appreciable amounts of other than volcanic rocks are less clayey and more sandy and their grain-size histograms have a less prominent mode. For instance, sample $53-13$ (Figure 36) from the mountain front south of Coombs contains much granodiorite and sample 53 - 16 (Figure 36) from the base of the mountain front at Rosewall Creek contains appreciable amounts of grandiorite and sandstone and is similar to the tills on adjoining parts of the coastal lowland. A very few clayey tills (e.g• sample $52-7$, Figure 36) contain chunks of clean clay that probably have been derived from overridden lake beds. All the clay-loam tills of the mountains contain an abundance of gravel; the one sample that has been completely analysed contains 44 per cent of gravel and boulders. The sandy-loam tills of the mountain part of the area (Figure 36, samples $52-9,52-14$ ) areeven more stony than the clay-loam tills but, unfortunately, no complete analyses of their gravel fraction are available. Their grain-size distribution is like that of poorly sorted gravel but they are here classified as tills because of their lack of stratification, their firm coherent consistency, and their content of silt and clay. 

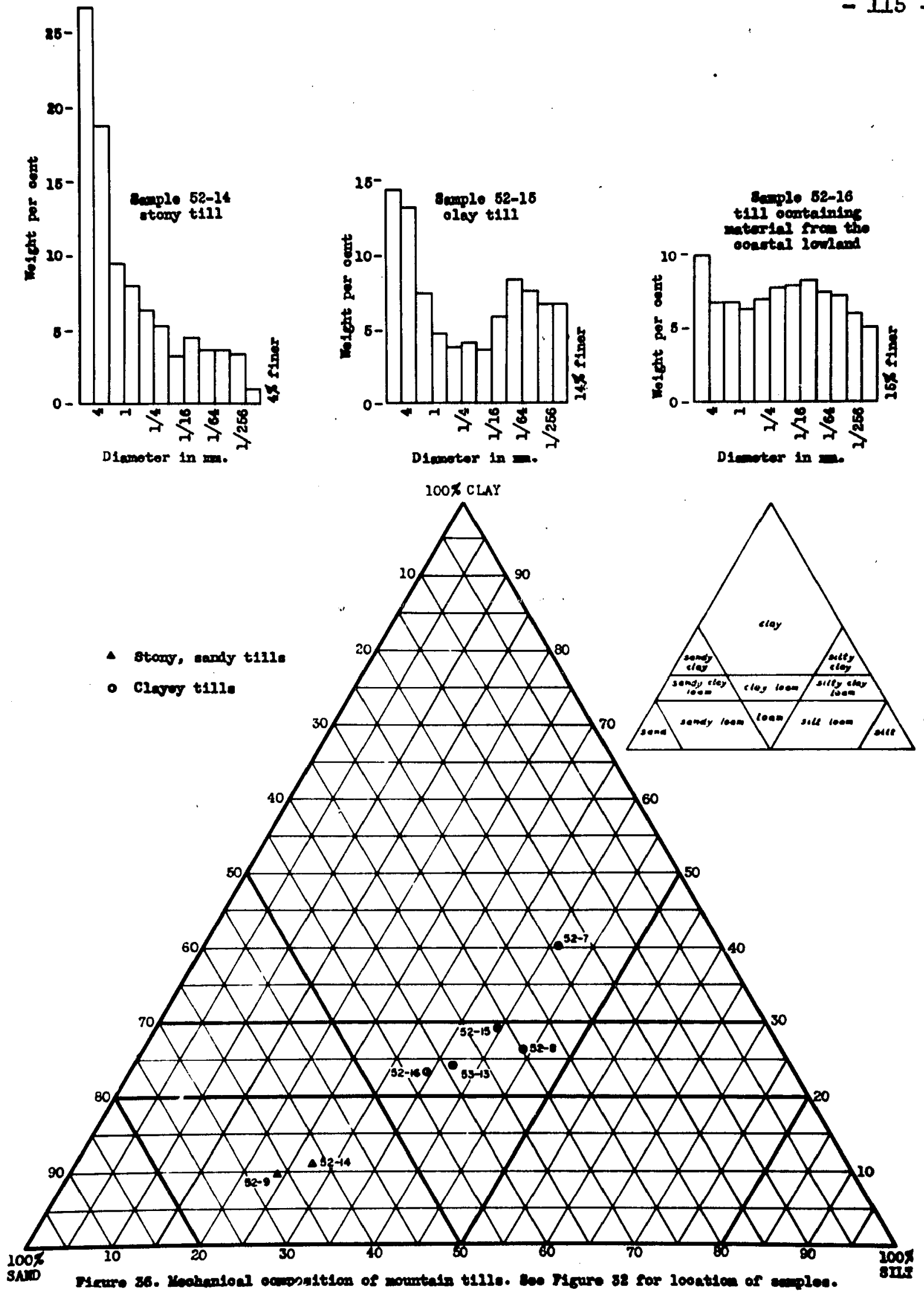
Stones in both the clayey and sandy-loam tills of the mountains are dominantly angular fragments of the local bedrock but almost universally include isolated rounded foreign stones. Tilllike materials that contain no recognizable foreign stones (ie. in which stones are all angular and of local bedrock) have been tentatively classified as mudslide and other colluvial materials. Tills of Rosewall Creek Valley and of the through valley from Rosewall Greek to Horne Lake contain a few granodiorite and sandstone pebbles and a few rounded volcanic pebbles that probably were carried from the Georgia depression by southward-moving glacial ice. Abundant granodiorite pebbles in tills in Cameron Valley northeast of the Alberni pass appear to have been derived from the granodiorite pluton at the mouth of the valley and thus record westward and southward glacial movement up the valley (see Figure 50). Lenses of silt, sand, and gravel have been found beneath and within till in many of the mountain valleys but all seem to be very local and nowhere has any indication been found of superposition of till upon extensive lacustrine and fluvial deposits. Gut banks along the highway on the south side of Cameron Lake expose till-like materials overlying sand and silt which, in turn, rest upon till and bedrock. The presence of slurm structures in the tilllike materials over the sands suggests that they have been redeposited by down-slope movements, and the sands and silts appear to have been formed during or since deglaciation in a lake standing about 50 feet above the present lake level. 
Superposed tills of different textures (Figure 37) are exposed in cuttings along a logging road that angles down the northwest wall of the gorge occupied by Rosewall Creek where it passes from the mountains to the high rocky bench along the inland edge of the coastal lowland. Rosewall Creek crosses this bench in a narrow, rockcut valley 300 feet deep that has been filled or partly filled with till and then re-excavated by the modern stream down to the bedrock floor of the buried valley. If the till layers of the valley filling are horizontal, cut banks successively lower on the slope must expose successively older tills, but if the till layers follow down the valley walls, all the cut banks may well expose the same tills. If, as seems most likely, the second interpretation is correct, about half a dozen distinct till sheets are exposed in the road cuttings. The uppermost till, about 10 feet in thickness, is a stony clay loam (sample $52-16$, Figure 36) very similar to nearby tills of the coastal plain. Many of the stones in this till are sub-rounded or sub-angular although some are aharply angular; 7 per cent consist of granodiorite, 3 per cent of sandstone, and the rest of volcanic rocks. The underlying till, about 5 feet in thickness, is typical of the clayey tills of the mountains (sample 52 - 15, Figure 36). Stones in this till are dominantly angular and, except for very rare granitic pebbles, they consist of volcanic rocks. Beneath this clayey till is more than 5 feet of very stony, sandyloam till (sample 52 - 14, Figure 36) containing both sub-rounded and sharply angular stones and including appreciable numbers of granodiorite, sandstone, and shale pebbles as well as those of volcanic 


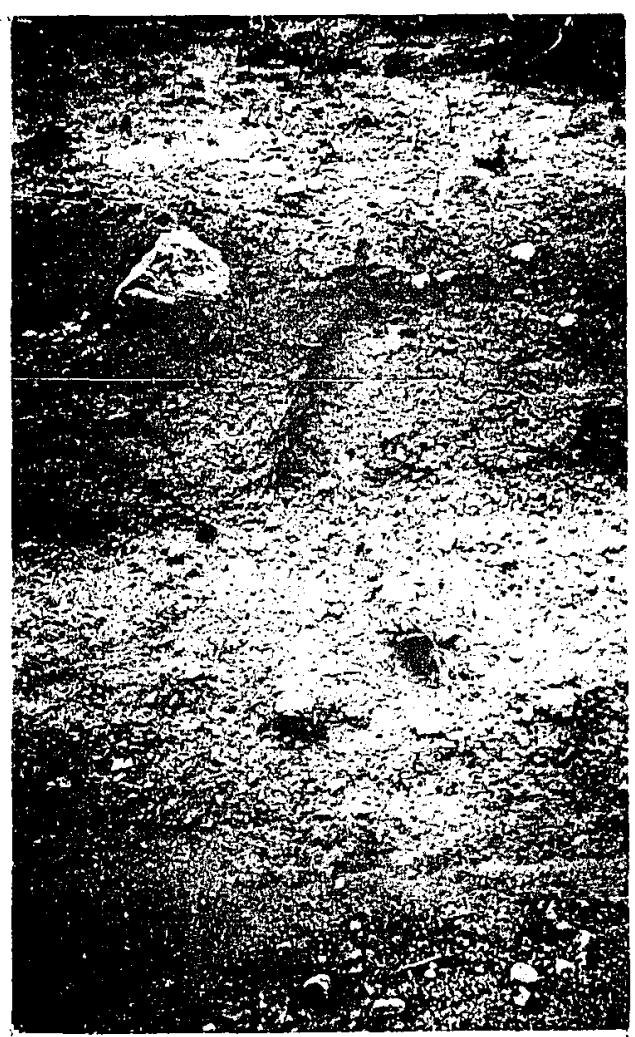

Figure 37. Tills exposed in a road cut on the bank of Rosewall Creek where it flows out of the mountains. Dark material is clayey till; underlying li wht coloured material is very stony sandy till. The large boulder is about 15 inches across. 
rocks. Fabric orientations of all three tills trend slightly east of south almost exactily parallel to the direction of dip of the valley wall immediately below but also parallel to the expected local direction of movement of glacial ice across the upland if it were flowing either into or out of the mountains through Rosewall Creek Valley. Tills lower on the sope are in part similar in texture and percentage of rounded and foreign stones to the second and third tills described above and in part have a different combination of properties (e.g. sandy till containing almost exclusively angular volcanic stones, etc.). These superposed tills of contrasting textures and stone content may record successive glacial movements into and out of Rosewall Greek Valley and along the southwesterm margin of the Georgia depression---and, if so, several stages of glacial advance and retreat must be represented. On the other hand, except for the top layer, which lies above the valley rim, they may not be undisturbed, primary glacial deposits but rather colluvially redeposited "tills" that have crept in successive sheets down the steep valley wall. The uppermost till, like the tills of adjoining parts of the coastal lowland, probably was deposited by glacial ice moving southeastward along the edge of the Georgia depression or, perhaps, southward into (across?) the mountains.

\section{Alberni Valley Tills}

Tilil constj tute: the major part of the surficial deposits of Alberni Valley. It forms a relatively continuous mantle in the eastern part of the valley where it locally exceeds 100 feet in thickness. In the western part of the valley till merely fills the bottoms of depressions between bedrock hills a few tens of feet in 
in height and thinly veneers of the hill sopes. Along the base of the steep northeast wall of Alberni Valley till is mingled with colluvial and alluvial-fan materials very similar to the till itself to form a wedge of sediment locally more than 100 feet in thickness. In most places the till lies directly upon bedrock but locally, as revealed by isolated drilled wells southeast of Beaver Greek and by a few cut banks along Stamp River, it is underlain by gravel, sand, or silt.

Much of the till topography of Alberni Valley is a subdued replica of the bedrock topography beneath it. On the other hand a narrow belt of hummocky constructional till. topography with relief up to 50 feet extends along the east side of the valley floor from Spaht Creek southeastward to Cherry Creek. West of Iongitude 125 degrees (e.g. in the Great Central map-area west of the Horne Lake area) the till surface is marked by small drumlinoid ridges and furrows averaging 1000 feet long, 200 feet wide, and 10 feet high. These trend southeast, east, and northeast (see Figure 38 and 50) and record glacial movements converging towards the junction of Lanterman Creek and Ash River. Many of them take the form of drift tails appended to bedrock knobs. Less-regular till ridges trending across Alberni Valley at right angles to nearby drumlinoid ridges occur along the northeast side of the valley adjoining the drumlinoid zone. These ridges range from 3 feet high and 100 feet long to 50 feet high and 500 feet long. They may be crevasse fillings. Tills of Alberni Valley are grey, compact materials similar in appearance to those of the coastal lowland but generally somewhat 


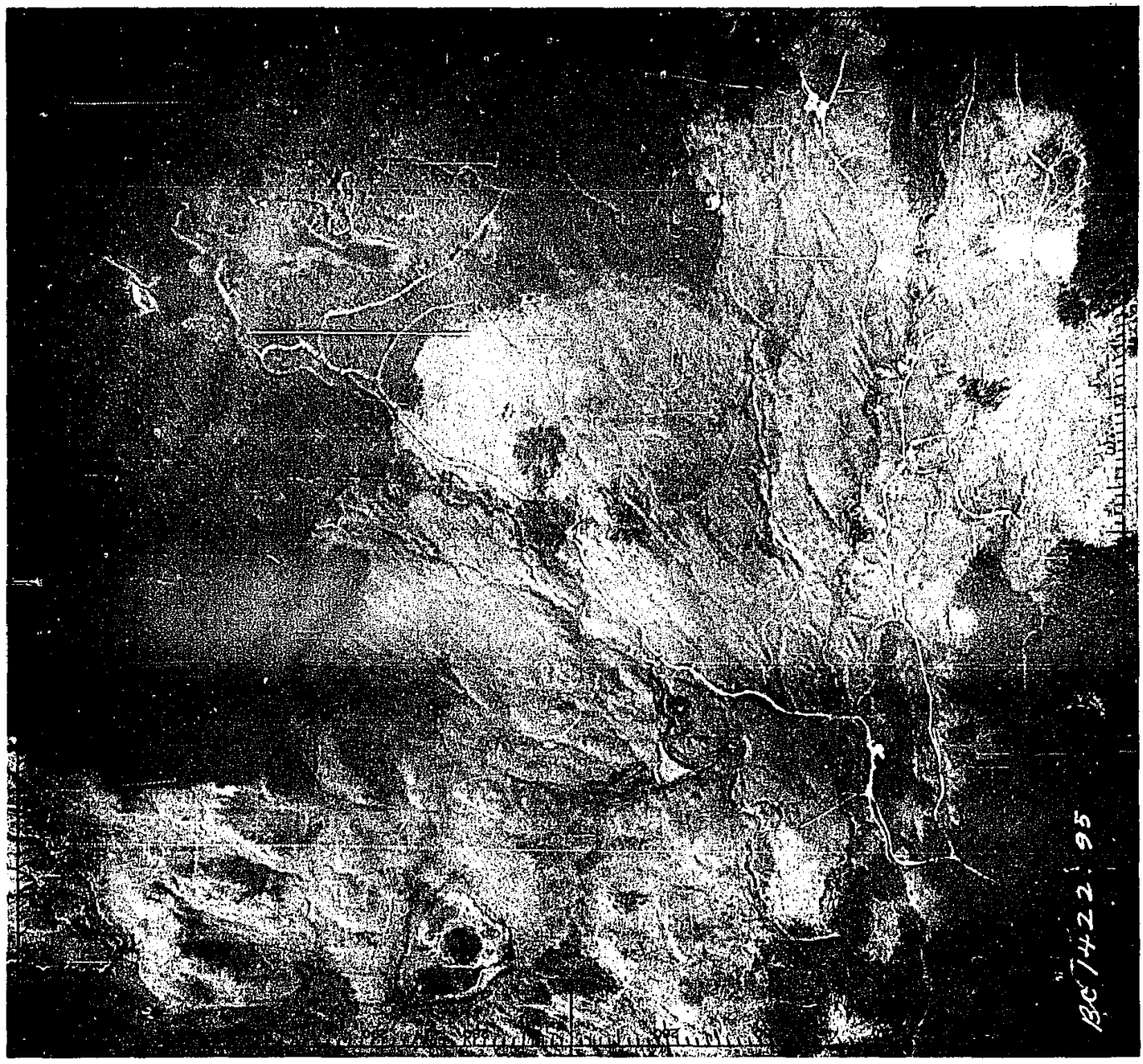

Figure 38. Vertical aerial photograph of the northern part of Alberni Valley showing drumlinoid ridges converging towards the junction of Lanterman Creek and Ash River (lower right). Dickson Lake at upper left, Moran Lake at bottom centre. Approximate scale 1 inch to half a mile. British Columbia government air photograph. 
more stony. In most tills, the stones are dominantly sub-angular to sub-rounded but, in some, they are sharply angular. Most tills of Alberni Valley have a clay loam to loam matrix containing about 20 per cent of clay but those along the west side of the valley and in Sproat and Great Central Valleys have a sandy-loam matrix with less than 10 per cent of clay. This distinction is illustrated by the triangular sand-silt-clay diagram (Figure 39). The grain-size distribution diagrams of these tills show no consistent or distinctive properties and therefore are not reproduced here. The histograms do reveal that some of the tills are almost completely unsorted.

The till forming the ground moraine along the northeast side of the floor of Alberni Valley has a loam to clay-loam matrix and contains fewer granitoid pebbles and more numerous sandstone and shale pebbles than other tills of the valley; 11 pebble counts of this type of till average 8 per cent granodiorite, 11 per cent sandstone and shale, and the balance basic volcanic rocks. Such a mixture of pebbles in the till would most probably result from southeast ice movement along the northeast side of the valley, and the presence of southeast-trending drumlinoid ridges on the till near Lanterman Creek confirms this inference. However, till east of Alberni and Port Alberni contains a few pebbles of crystalline limestone, purple chert, and chlorite schist that seem to have come from outcrops to the northeast between Alberni Valley and Horne Lake. 


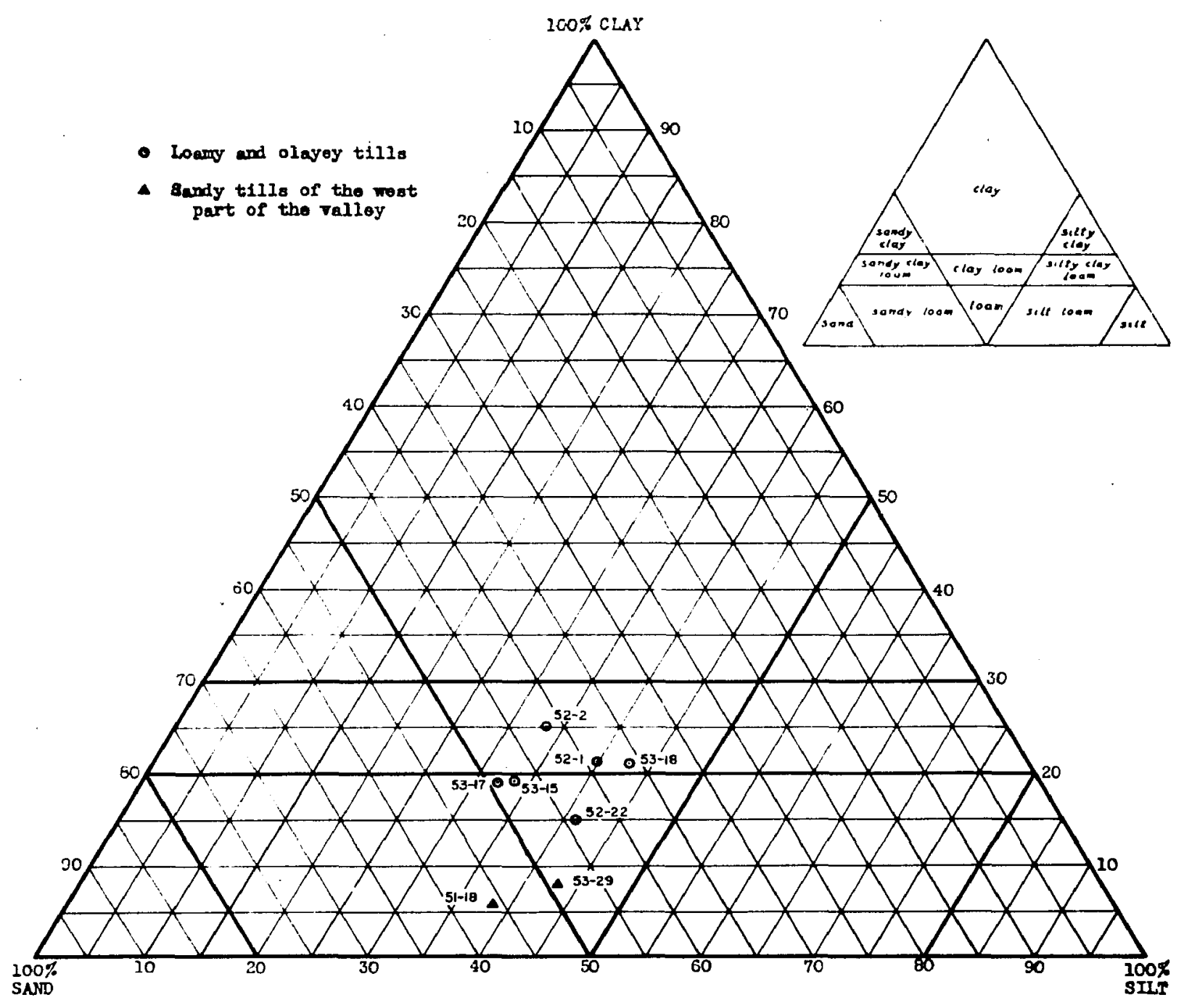

Figuro 39. Hoohanioal omposition of the minus 2 mm fraotion of tills of the llberni Valloy. sand, silt, and olay aro defined in terms of the Fentworth grado soalo. 
Tills along the middle of Alberni Valley from the junction of Ash and Stamp Rivers to the head of Alberni Inlet characteristically have a loam to clay-loam matrix like the till to the northeast but contain a much higher percentage of granitoid stones. A typical pebble count is 30 per cent granodiorite, 4 per cent sandstone and shale, and 66 per cent volcanic rocks. Tills near Stamp Falls contain pebbles of dense, dark limestone containing Buchia that probably originated to the west, perhaps along Great Central Valley. The abundant granitoid stones in these tills may also have been brought in from the west (ice movement down Great Central and Sproat Valléys) but, alternatively, may have been brought down Alberni Valley from the granodiorite body east of Dickson lake or may have been picked up by the ice from granodiorite-rich gravels that have locally been found within and beneath the till. Fabrics of some of these granodiorite-rich clay-loam tills trend southeast parallel to the axis of Alberni Valley while others trend northeast across the valley (Figure 50). They may reflect two distinct glacial movements or may be parallel and transverse fabrics related to a single movement.

Tills along the west side of Alberni Valley are less clayey, more sandy, and more stony than the tills described above and are intermingled with numerous lenses of gravel, sand, and silt. They are generally less than 10 feet in thickness. In a typical sample, 30 per cent of the pebbles are granodiorite and 70 per cent are volcanic rocks. Much of this sandy-loam till seems to have been deposited by ice moving into Alberni Valley from the large 
tributary valleys to the west. For instance, small crag-and-tail hills of sandy-loam till southeast of the east end of Great Central Lake trend east-southeast as if formed by ice moving out of Great Central Valley. Around Moran Iake, the sandy-loam till is surfaced by drumlinoid ridges trending northeast and apparently formed by ice moving over the pass from Great Central Valley; farther north, the sandy-loam till bears drumlinoid ridges trending east and apparently formed by glacial movements out of the Dickson Lake-nsh Lake-McLaughlin Lake Valley. In this northern part of Alberni Valley, the sandy-loam till extends about half way across the valley and is bordered by the clay-loam till containing few granitoid pebbles. Farther south, the belt of sandy-loam till is narrower and is bordered on the east by granodiorite-rich clay-loam tills.

Iittle is known of the relative age of the various tills of Alberni Valley. Upper and lower tills separated by a few feet of gravel and sand are exposed in various cut banks along Stamp River and lenses of till are intercalated with sand and gravel in gravel pits adjacent to Somass River. None of these exposures give any indication of a significant lapse of time. Half a mile down Stamp River from its junction with Ash River two sheets of clayloam till separated by a boulder pavement are exposed in the river bank. In the lower till 23 per cent of the pebbles are granodiorite, 10 per cent are sandstone and shale, and 3 per cent are limestone whereas, in the upper till only 7 per cent of the pebbles are granodiorite, 5 per cent are sandstone and shale, and none are 
limestone. The fabrics of both tills trend northeast (see Figure 50). In the acute angle between Lanterman Creek and Ash River close to the eastern edge of the belt of sandy-loam tills, a railway cutting exposes granodiorite-rich sandy-loam till overlying less stony, clay-loam till containing a much smaller percentage of granodiorite pebbles. The two relationships outlined above suggest that the granodiorite-rich, clay-loam till of the middle of the valley is older than the granodiorite-poor clay-loam till along the east side of the valley, and that this, in turn, is older than the granodiorite-rich sandy-loam till of the west side of the valley. The overall relationship, however, is probably much more complicated. As yet, it is not even known which of the tills were formed more or less contemporaneously by glacial ice converging from different sources and which, if any, represent successive glacial invasions.

\section{GLACIOFLUVIAL AND GLACIOLACUSTRINE FEATURES}

Resting upon the ground morain $\epsilon$ of the Vashon group are gravel, sand, and minor silt that appear to have originated in streams and probably lakes surrounded by glacial ice or confined between ice and higher ground. Some of these deposits show distinctive ice-contact topography while others are perched on hillsides in positions such that the streams or lakes in which they accumulated must have been damed by glacial ice. A few small abandoned stream channels and indistinct shorelines appear, likewise, to have been formed by glacial streams and lakes. Many of the glaciofhvial 
deposits within the area take the form of more-or-less conical hills (kames) or occur as groups of such hills interspersed with closed kettle depressions (kame fields). A few are elongated esker ridges. Other glaciofluvial deposits form terraces that locally are pitted by kettle holes and in part are bordered by knob-and kettle slump slopes. These include kame terraces, which appear to be the deposits of streams that flowed between glacial ice and higher ground; ice-contact alluvial fans, which formed where streams flowing down steep valleys reached the margin of a lowland ice mass; and "kame deltas" which appear to have accumulated where glacial streams entered the sea amid remnant masses of glacial ice.

\section{Albermi Valley}

Esker System

The glaciofluvial deposits of Alberni Valley integrate into several independent series that outline separate meltwater drainage systems. One of these is an esker-channel complex that has been traced about 7 miles northwest from Stamp Falls. This group of features heads about 3 miles west up Ash River from the west boundary of the Horne Lake area (Plate IA) in three small abandoned stream channels 1 to 2 miles long that trend east, east-southeast, and southeast parallel to adjacent drumlinoid ridges and that converge towards the junction of Ash River and Lanterman Creek. About a mile up Lanterman Creek from its mouth they merge as a complex of anastamosing esker ridges of well-sorted pebble gravel about a mile long and these, in turn, pass eastward and southeastward into a series of kames and channels cut in sandstone along the 
slope east of Lanterman Creek (west edge, Plate IA). These kames and channels disappear beneath alluvium and Iandslide debris along the boundary between the Newcastle and Alberni land districts but reappear about a mile to the southeast (see geological map) as small kame fields and as a series of well-defined, southeasttrending esker ridges. The longest of these ridges has been traced for $1 \frac{1}{2}$ miles. A pitted terrace deposit immediately east of the southernmost esker ridge appears to be the terminal deposit of the esker system. On the basis of map distribution this terrace might correlate instead with a group of kames and kame terraces to the west (see Plate IA), but pebbles in these ice contact deposits to the west include 50 per cent of granodiorite and generally none of sandstone, whereas pebbles in both the esker and the pitted terrace include only 10 to 15 per cent of grandiorite and several per cent of sandstone. The terminal pitted terrace probably was deposited by the esker stream where it reached an ice front and, in view of its horizontal upper surface, it may be a delta. No other terminal deposits have been recognized along or adjacent to the esker system and therefore this esker may have formed as a single unit while the ice front stood in one position rather than as a series of short segments adjacent to successive retreatal ice fronts.

Great Central Kame and Kame Terrace System Gravels with ice-contact topography form an irregular complex belt up to half a mile wide extending from Great Central to Stamp Falls. They seem to be deposits of glacial streams that originated in Great Central Valley and flowed eastward along the 
margins of low hills projecting through thin remnant ice. A belt of kames and narrow terraces follows the present drainage northward from the outlet of Great Central Lake for about $I_{\frac{1}{2}}$ miles (Plate IA) to the junction of the main river with the overflow from Bot Lagoon. Thence, knobby and ridged gravels extend across a Iow divide (30-foot rise) to a swampy lake about a mile to the southeast. From the lake a kame terrace extends southeast about 2 miles between a till ridge on the north and a series of bedrock hills on the south and is separated from the lower country to the southeast by an irregular ice-contact face. Extending northeast from the swampy lake, between the kame terrace and the supporting tili ridge, is a narrow belt of kames standing a few feet above the terrace level. These kames lead to a small abandoned stream channel that has been cut off on its north end by Stamp River. Another narrow belt of kames and kame terrace extends about half a mile north from the swampy lake around the opposite side of the till ridge.

Both the terrace deposits and the knobby kame deposits consist dominantly of pebble and cobble gravel but include beds of sand and silt. The kame deposits are irregularly stratified and generally are less well sorted and coarser than adjoining terrace materials. Most terrace deposits are horizontally stratified although some near Great Central have slump and kettle-fill structures (Figure 40). Pebbles in both terrace and kame gravels are about half volcanic and half granitoid. Gravels seem to get finer from west to east and the main kame terrace deposit grades from 


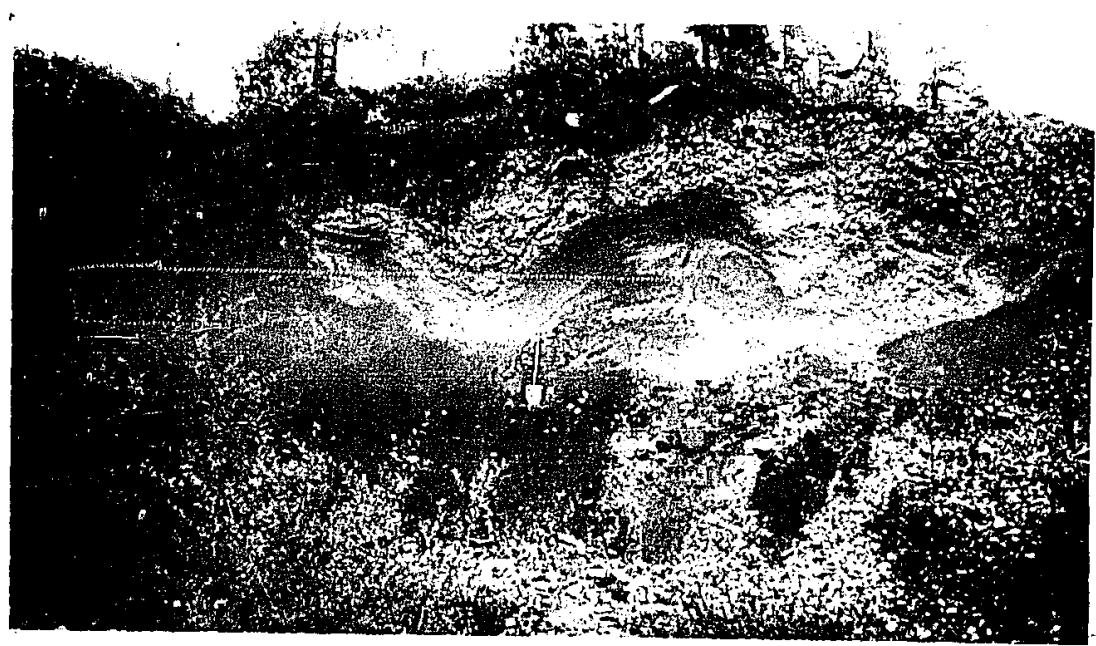

Figure 40. Slump or kettle-fill structures in kame terrace gravel; old railroad cut about a mile north of the outlet of Great Central Lake. 
pebble gravel in the west to pebbly sand (at least locally resting on sand and sit) in the east. The gradient of the terraces is very low and all terraces lie between $290^{\circ}$ and 310 feet above sea-level. This system of kames,kame terraces, and channels clearly records drainage of glacial meltwater from the Great Central Valley by several routes to the east and northeast instead of by way of the present northward loop of Stamp River. Apparently, when these deposits were formed, solid glacial ice north of the outlet of Great Central Iake blocked the natural drainage route and diverted the meltwater streams eastward through and around thin and discontinuous ice. The downstream end of the main kame terrace (near Stamp Falls) lies within a few feet of the upper limit of marine submergence in this part of the valley, and it seems likely that the depositing stream terminated in marine water just west of the present site of Stamp Falls. This suggestion is based upon the contrast between the fresh ice-contact features of part of the southeast face of the kame terrace and the smooth wave-modified appearance of other parts, as if parts had been confined by ice while other parts were being built into standing water.

Sands and silts up to 20 feet in thickness occupy an area about a mile across along Stamp River between the north edge of the kame-terrace complex and Ash River (Unit 9, Plate IA). Although these deposits may be marine, they are more prominently laminated than most sandy and silty marine deposits of the region and are not accompanied by the typical marine clays. Probably they accumulated 
in a lake dammed at the north end by glacial ice. The ice dam appears to have been just south of the junction of Ash and Stamp Rivers, a mile or two north of the position of the earlier ice barrier against which the kame-kame terrace complex had been built. A short abandoned channel through the till ridge that confines this area of sands and silts on the east (Plate IA) may have been the outlet of the lake. This channel has been cut off at its downstream end by Stamp River and, therefore, its relation to the former high sea-levels is not known.

\section{Stirling Arm Terraces}

An ice-marginal river system that flowed eastward from Sproat Valley along the southern edge of the floor of Alberni Valley is represented by three small kame terraces and an abandoned river channel between Stirling Arm and the head of Alberni Inlet (see Plate IA). The kame terraces are flat-topped bodies of pebble gravel and sand bordering small bedrock hills. Their outer edges are steep but relatively regular and lacking in kettle holes or other features indicative of ice-contact slopes. Isolated kettle holes occur in the terrace tops and between the gravels and the supporting bedrock hills. Stratification near the edges of the deposits parallels the bordering slopes but the few cut faces well back from the edge reveal horizontal bedding. In places, adjacent terraces differ in elevation by 5 or 10 feet but they all seem to be between 260 and 280 feet above sea level. Despite the absence of ice-contact forms along the margins of these deposits, the writer believes that their accumulation as isolated, flat-topped 
deposits on the sides of bedrock hills entirely lacking in source materials can only have taken place in a river flowing in part on remnant ice and in part around the margins of hills projecting through the ice. They are localized at the base of the mountain slope at the south edge of the valley floor as if the river by which they were deposited was confined between the hills to the south and the wasting margin of glacial ic e in sproat and Alberni Valleys. The terrace surfaces are slightly (10 to 30 feet) below the limit of marine submergence. This similarity of level may be a coincidench but, alternatively, may indicate that the level of the terrace surfaces was controlled by the level of a nearby marine body. Harine water has surrounded, and probably covered the terraces since their formation, as is incicated by the distribution of surrounding marine clays. Probably the presence of sand fillings in some of the kettle holes in the terrace surface as well as the absence of ice-contact forms on the bordering slopes are attributable to marine action.

\section{Somass Gravels}

Fxtensive deposits of gravel and sand occur along the valley of Somass River and along Stamp River for a few miles above Somass River. Some of these are mare or less isolated hillside bodies that have been subjected to erosion and buried beneath marine clay and that provide no suggestion of their original form. Others occur beneath a series of terrace remnants. Some of these were deposjted by the same agency that built the terraces but many are earlier deposits that have been buried beneath or truncated by the terraces. Thus the original constructional form of many of the 
Somass River gravels has been concealed or destroyed, and decision as to whether they are glaciofluvial deposits or whether normal river deposits has had to rest upon their internal structures. Some of the hillside gravels are intercalated with lenses of till, and therefore are confidently classified as ice-contact deposits. For instance, the hill, about 100 feet high, projecting through the estuarine fill at the west side of the head of Alberni Inlet consists of such materials. A gravel-pit face in the south side of this hill (Figure 4]) exposes irregularly stratified dirty bouldery gravel and silty sand that enclose a few lenses of till ( $T$ in photograph). In another cut face a few feet to the right of the photograph, till lenses are larger and more numerous but the enclosing gravels are more regularly stratified, better sorted, and are pebbly rather than bouldery. The hill in which these glaciofluvial materials occur is veneered with lag gravel and probably is an erosional remnant of a much more extensive deposit. Other hillside gravel deposits bordering Somass Valley contain no till lenses but are characterized by basin-like structures, contortions, and faults. As outlined below, these deposits seem to be glaciofluvial. These disturbed gravels and sands are best exposed in two adjacent gravel pits west of Somass River just north of the Indian Reservation. The west face of one pit is illustrated in Figure 42 and the south face of the other is sketched in Figure 43. The main deposit is pebbly gravel up to 40 feet in thickness resting upon till and bedrock. Overlying the gravel in some places are 10 to $15^{\circ}$ feet of pebbly sand and in others an 


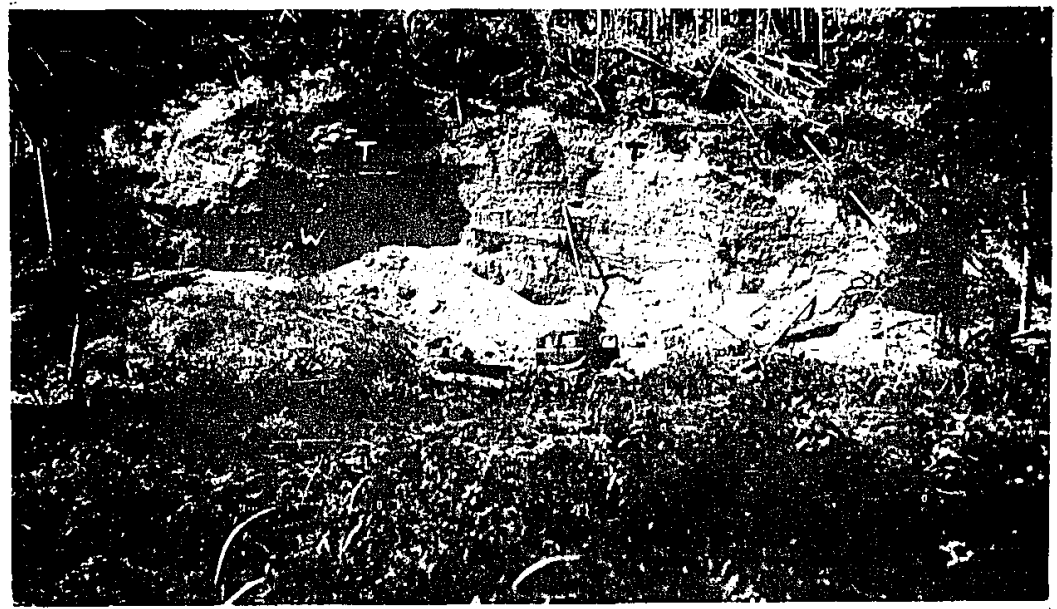

Figure 4l. Pit in gravel hill just north of Johnstone Island, head of Alberni Inlet. $T$, till lens; $W$, silt and silty sand containing wood.

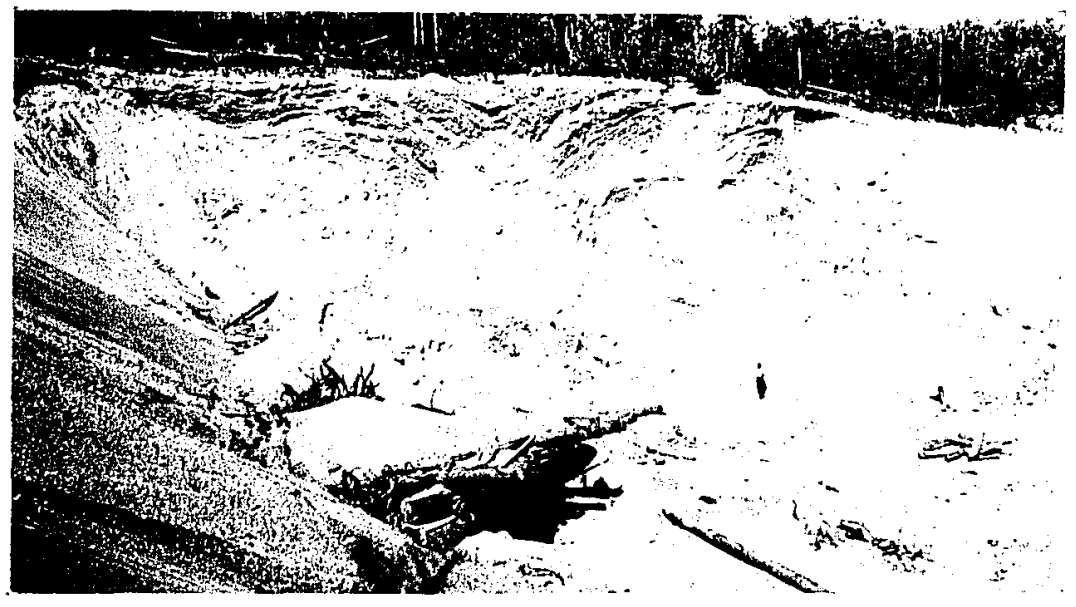

Figure 42. Face of pit in hillside gravel deposit west of Somass River about a mile downstream from junction with Sproat River. The basin structures consist of laminated clay, silt, and sand and rest upon thick sandy gravel. Undeformed marine clay over-

lying the deformed beds can be seen in the left part of the photograph at the top of the face. A surface veneer of pebbly sand has been removed by bull dozer. 


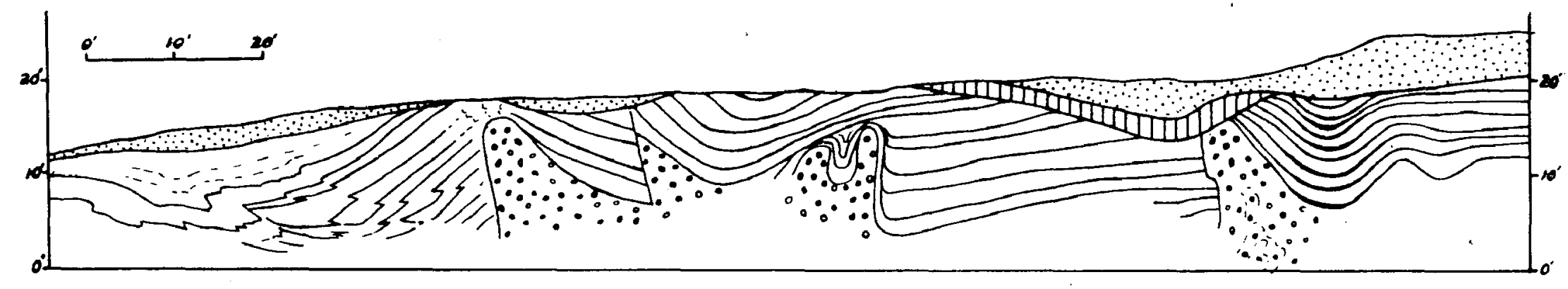

\section{: Pobbly sand}

Fobble gravel and sand oontaining silt and olay that thicken in the "basing"

Plgure 43. Strnoture of hillside gravel deposit, west side of Somass River skotohed from photographs and field dravings of a gravel pit face. 1/l|| Clay with marine shells

$\because \because$ Pebbles, mainly unstratifled 
equal thickness of silt and clay interlaminated with pebbly sand. All these strata are involved in the complex disturbed structures show in the illustrations. Overlying them are undisturbed lenses of clay up to 5 feet in thickness containing casts of marine shells and of pebbly sand up to 10 feet in thickness.

The disturbed structures can be explained in part in terms of down-slope movements which resulted in crumpling and faulting of the deposits, although the present surface slope (Iess than 5 degrees) seems inadequate to have induced such movements. The intricately faulted pebbly sand at the downslope end of the crosssection (Figure 43) seems best explained by such down-slope movements, and the crumpling that produced the protrusions of pebble gravel in the middle of the cross-section may have taken place in the same way. On the other hand, the basin structures like those at right end of the cross-section and in the photograph are more or less circular in plan, whereas folds formed by downslope movements would be expected to be trough shaped. Circular pits in gravel in glaciated regions are generally ascribed to the melting of buried ice blocks and it seems reasonable to assume that these basin structures, which occupy pits in gravel, may have had a similar origin. The occurrence, beneath one of the basins, of a knot of poorly sorted, unstratified bouldery gravel, such as might remain upon melting of an ice block, lends support to the above suggestion. Melting of buried ice blocks would also provide the force necessary to initiate the downslope movements that appear to have caused the faults and related structures. 
The clay and silt layers involved in the basin structures are thickest in the bottoms of the basins and thin progressively towards the margins. The thick basin-bottom parts of some clay layers are breccias consisting of angular pieces of clay separated by seams of dirty sand apparently derived from the adjoining sandy beds, but other clay layers thicken without brecciation or any sign of deformation. The sediments forming the basins probably accumulated during the subsidence of the ground surface that accompanied melting of the buried ice blocks rather than before or after this subsidence. Thus, as melting of a buried ice block began, a shallow depression would form in the gravel surface and would be filled or partly filled with clay or sand. With continued melting, this bed would sag to produce another shallow depression that in turn would be filled with another layer or sediment. The brecciated clays must have been rendered dry and brittle before deformation and therefore, if the above interpretations are correct, intervals of drying (ie. lowered water level) must have alternated with intervals of sedimentation.

The terrace remnants along Somass and Stamp Rivers seem principally to be parts of a single sloping surface at about the same gradient as the present river system from 100 feet above sealevel at the junction of Stamp and Sproat Rivers to 30 feet above sea-level near the head of Alberni Inlet. Steep-sided embayments inthe terrace front half a mile up Somass River from McCoy Greek are suggestive of ice-contact faces but the writer has concluded 
that they are merely the result of recent gullying. Some of the terrace segments are constructional and pits dug into them expose a few feet to a few tens of feet of more or less horizontal, irregularly stratified pebbly sand containing a few beds of silt. In some places these materials pass dowmard into marine clay and in others they contain lenses of marine clay. On the other hand, thick gravels beneath many of the terraces are truncated by the terrace surface or buried beneath a thin terrace-topped veneer of pebbly sand, and probably are much older than the terrace itself. Some of these sub-terrace gragels contain till lenses or complex structures like the hillside deposits and therefore are probably remnants of ice-contact features. For instance, a gravel pit just south of the junction of Sproat and Stamp Rivers has penetrated through a thin veneer of pebbly sand and marine clay into gravel and sand with clayey interbeds and fault and basin structures very similar to the deposits described in the last section.

Other buried, truncated gravels beneath the terraces appear to be normal river deposits. Gravels of this sort occur in a large gravel pit, known as Dolan's pit, one mile up the east side of Somass River from the highway bridge. The pit has been dug into a terrace remnant 100 yards wide between the present cut bank of Somass River and the valley wall. The terrace is surfaced by 5 to 10 feet of more or less horizontal pebbly sand containing lenses of marine clay, lenses of till-like material, and isolated boulders. 
The till-like materials are sandy and loose textured and probably are fluvial skckwater deposits. Beneath these terrace-surface deposits, and truncated by the them, are pebble gravels dipping at 10 to 15 degrees down the valley, which abut against a steep till face that apparently is a buried river-cut bank. These inclined gravels probably were deposited by a large river swinging under this steep bank, but whether they were formed at about the same time as the terrace or whether they are significantly older is not known. Interpretation of the deposits in this pit is complicated by the presence of glaciofluvia] gravels containing till lenses at the top of the adjoining valley wall and by a veneer of gravel containing lenses of till-like (but apparently colluvial) material extending down the valley wall from glaciofluvial deposits to merge with the terrace deposits.

As is evident in the foregoing descriptions, a clear-cut classification of the gravelly deposits along Somass River has not been possible. For the purposes of this report, the terraces and the constructional terrace deposits are considered to be postglacial fluvial features and their significance will be discussed in connection with the Capilano group. The hillside deposits and the apparently correlative deposits buried or truncated beneath' the terraces are considered to be glaciofluvial ice contact materials. Their original form is not known but their alinement along the valley now occupied by Somass River may be an indication that they are remnants of an ice-bordered river system rather than isolated, unrelated bodies. 
Mountain Valleys

Narrow terraces and tiny alluvial fans perched on the walls of some of the mountain valleys appear to have been formed by streams at the margins of bodies of glacial ice occupying the valley bottoms and as shore features of ice-dammed lakes. These small, indistinct forms, for the most part, are recognizable and traceable only where the forest cover has been removed by recent logging or fires. Within the map-area these features are best displayed in the valley of Rosewall Creek and in adjoining parts of the valley leading thence to Horne Lake. Rosewall Greek Valley contains many alluvial fans built by tributary streams. Most of these either are still being formed or were formed when the valley floor was 50 to 75 feet above its present level, but a few of them, perched several hundred feet above the present stream, are too high to have built upon any post-glacial floor of Rosewall Creek Valley (see Flgure 44). One of the highest of these fan remnants borders Roaring Creek, a tributary of Rosewall Creek. If the surface of this fan is projected downslope across the valley of Rosewall Creek it passes above the top of the constructional till ridge that here forms the opposite wall of the valley. Hence, it must have been built against glacial ice or into a lake in Rosewall Creek Valley. Other high fans bordering the valley lie at various elevations rather than at a single elevation and therefore they probably were built against ice rather than into a lake. Very narrow, scarcely perceptible terraces occur along the walls of Rosewall Creek Valley and the valley leading 


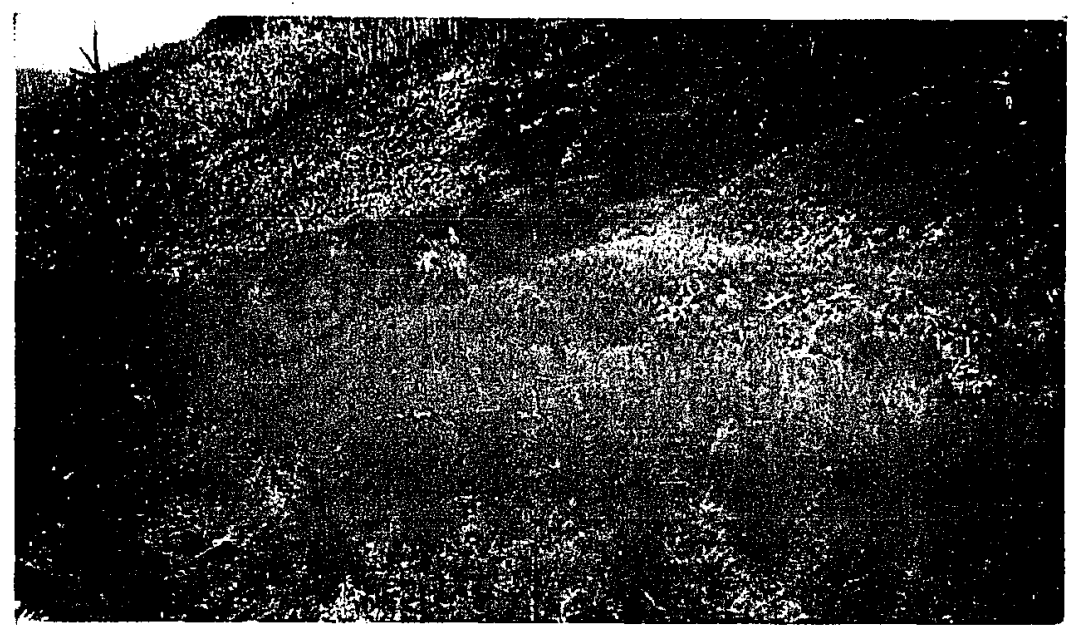

Figure 44. Alluvial fans, Rosewall Creek Valley. The highest fan remnant left of the gully is belleved to have been built against glacial ice occupying the valley bottom.

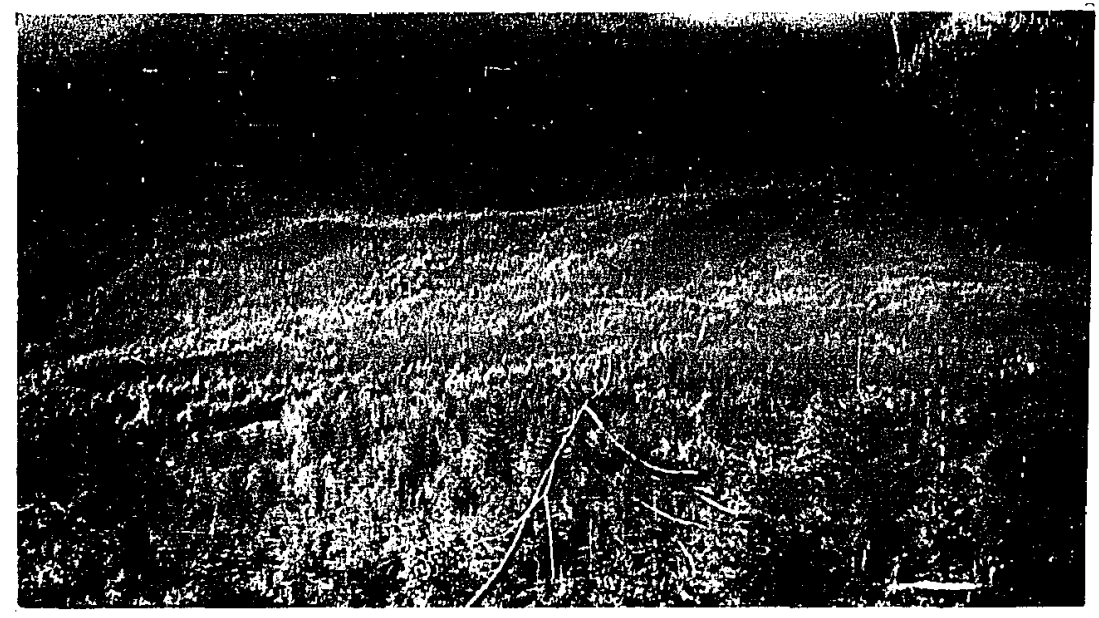

Figure 45. Remnant of ice-contact alluvial fan, headwaters of Chef Creek. View south from hill at Bowser Forestry Lookout showling upper surface of fan terminating at its lower edge in a hummocky ice-contact slope. The stream that deposited the fan flowed out of the gully at the right side of the photograph. 
from Rosewall Creek to Horne Lake. Some of them are notches cut into the thin till that mantles the valley walls and others are constructional deposits of pebble and cobble gravel. Although many of them occur at or close to the same elevation, and on this basis might be interpreted as lake shore features, some of those visited on the ground are sloping in along-valley profile rather than horizontal and, hence, are interpreted as the beds of ice-marginal streams.

High terraces and fan remnants have been encountered on the wooded valley walls bordering Cameron Lake and Cameron River. They probably are ice marginal or lake features but because of the forest cover, little is known of them. Deltas, beach terraces, and accumulations of stratified sand and silt are found on the lower hillsides bordering Cameron Lake. The most prominent of these record a former stand of the lake about 50 feet above its present position. It is not known whether these former lakes were dammed by glacial ice or by unconsolidated deposits in the valley mouth that have since been removed in cutting the present channel of Little Qualicum River.

Small terraces and fan deposits on the valley walls bordering Horne Lake and terrace deposits in the valley of Qualicum River west of the lake appear to be largely lake shore features but may include ice marginal features. Here, as in the Cameron Valley, no clear distinction has been made between the deposits of glacial ice-dammed lakes and those of the higher post-glacial stands of 
Horne Lake that existed prior to the cutting of the present valley outlet of the lake.

Coastal Lowland and Adjoining Parts of Valleys and Mountain Slope

Fans and Kames, Rosewall creek to Chef Creek

At the base of the steep, rocky mountain slope at the

headwaters of Chef Creek and McNaughton Creek is a more gentle, drift-covered hillside 1500 to 1100 feet above sea-level that forms the inland edge of the high bench here separating the coastal plain from the mountains. Streams emerging onto this slope from the steep, V-shaped mountainside valleys have deposited alluvial fans. The highest of these fans, which have been largely removed in forming the lower fans, are bordered at their distal edge by scalloped, irregular faces with kame-like hills (see Figure 45). Similar hummocky topography characterizes the interstream parts of the hill slope between these high fans. The high fan remnants are composed of poorly sorted, almost till-like, angular gravel consisting almost entirely of fragments of the local volcanic rocks. The knobby slopes along the outer faces of the fans and extending between them are surfaced in part by locally derived gravels and in part by better-sorted gravels containing appreciable numbers of sub-rounded stones and of stones consisting or rocks, such as granodiorite, that do not crop out in the vicinity. Clearly, these high fans are ice-contact features. They appear to have been deposited against the edge of a lowland ice mass partly by streams flowing out of the mountain valleys and partly by streams flowing along the ice 
margin. A tiny esker ridge extends downslope from a prominent kame near the eastern end of the eastermost fan. This ridge is cut of $f$ by a large gully but the esiker is apparently represented farther down the slope by a series of short ridge segments and kames that extend across the basin-like valley occupied by Chef Creek. The esker terminated in (or is buried by) the westernmost part of the belt of knobby, ice-contact gravels described in the next section of this report. The esker descends 800 feet in its 2 miles of length and trends approximately at right angles to nearby glacial striae and till fabrics. It appears to have been formed by the stream that deposited the fan to the south. Hence, the drainage from this eastermost fan probably escaped beneath the ice, whereas streams that deposited the fans farther west seem to have escaped along the ice margin.

The highest fan remnants along the hillsides range from 1700 feet above sea-level bordering the westermost stream to 1400 feet adjacent to the eastermost and appear to decrease progressively in elevation from west to east. They may well be contemporaneous deposits outlining a single stand of ice margin. Along the easternmost stream, a small fan entrenched 150 feet below the highest fan terminates in an ice contact face and records a later, lower position of the ice margin.

The belt of kames and ice-contact alluvial fans has been traced eastward only as far as the east end of the high bench 
separating coastal lowland from mountains. Bast of this, a thoroughly dissected apron of gravel, sand, and till borders the base of the mountain slope. On the accompanying geological map, the gravel and sand are classified as sub-till deposits possibly equivalent to the Quadra group but some of them may, alternatively, be remnants of hillside kame or kame terrace deposits related to the kames and fans to the west.

Belt of Kames, Chef Creek to Hunts Creek

A belt of hummocky gravel extends along the inland margin of the coastal lowland from Chef Creek to Hunts Creek. It is $3 \frac{1}{2}$ miles long, up to a mile wide, and for the most part, lies between 500 and 1000 feet above sea level. Most of the belt consists of closely spaced, more or less conical hills a few feet to 100 feet in height, but here and there elongated ridges lie parallel or transverse to the axis of the belt. Kettle holes are fairly abundant near Nile Creek but are rare elsewhere. Near the ends and inland margin of the belt, some of the topography is much less distinctive, comprising low irregular hills and poorly defined depressions. The gravel of which the kames are built is wellsorted to poorly-sorted pebbly and oobbly material with coarse sand matrix. A few kames and ridges consist principally of sand and pebbly and and many of them contain lenses of till. In most places where stratification has been seen it parallels the hummocky ground surface although one cut bank exposes thoroughly faulted stratification dipping into a kame almost at right angles to the 
side slope. Stones in the kame gravels are sub-angular to subrounded and, although most of them consist of volcanic rocks, several per cent are granodiorite and a few are sandstone. Large, more or less angular blocks of dark green trap are strewn here and there on the gravel surface, particularly in the western part of the belt. The west part of the kame belt, bordering the amphitheatre-like valley of Chef Creek, has not been clearly delineated. Here, the kames are poorly defined and the kame deposits have not been distinguished with certainty from gravels and sands occurring beneath thin, discontinuous till or from the ridged esker gravels mentioned in the preceding section of this report. At one point on the northwest rim of the Chef Creek amphitheatre, two tiny river channels have been cut through the ridge crest and terminate in the kame belt, half a mile to the north, as a fan-shaped group of high kames. These channels and terminal kames are believed to have been formed by a stream flowing off a glacial remnant in the Chef Greek Valley and onto lower glacial ice to the northeast. The kame belt is bordered on the northeast by marine deposits and by materials modified by marine action. Almost everywhere, the marine submergence obviously took place after formation of the kames and, as indicated on the geological map, the easternmost part of the kame belt is covered by a thin marine wash. On the other hand, in the head of a small gully on the downslope side of Chef Creek Forestry Road on the northern boundary of the kame 
belt, massive clay containing marine shells and isolated stones is overlain by a few feet of gravel and till-like material. This succession may indicate a glacial advance over marine deposits or may mean that marine waters penetrated into intra-ice openings while the kames were being formed. Alternatively, however, the till-lilke material on the marine clay may have been emplaced by down-slope movements during marine submergence or may have been dropped by icebergs.

The kame belt is not associated with any terrace-topped, fan-like, or delta-like deposits nor with channels or outwash deposits and, therefore, cannot have formed along any ice margin or series of margins but must have been flanked on both sides by ice. The long axis of the belt parallels the last glacial movement in this part of the area. Relative to this movement, the kame belt is in the lee of the steep slope, 500 feet high, separating the high bench between waterloo Creek and Chef Creek from the lower coastal plain. If the glacial ice covering this slope were thin, a zone of crevasses would be expected to coincide with the belt now occupied by the kames. Possibly the kames were deposited on, within, or at the base of the ice by streams flowing along such a crevasse system. Parts of the kame belt are 1000 feet above sea-level and must have been formed when the glacial surface was above that elevation, whereas the kames at the north end of the short channels cutting through the rim of Chef Creek Valley must have formed when the ice surface was only 600 to 700 feet above sea-level. 
Thus, the meltwater drainage system in which the kames were formed probably persisted over a considerable range of positions of the upper ice surface and may well have been contemporaneous both with the mountainside fans and kames discussed in the last section and with the Spider Lake terrace described below.

$$
\text { Spider Lake Kame Dalta }
$$

Blocking the mouth of Horne Lake Valley east of the present course of Qualicum River is a large gravel terrace pitted with numerous closed depressions the la rgest of which is occupied by Spider Lake. As shown in Figure 46 it is delta-like in outline, fanning out to the north and east from the top of the steep slope bordering the northeast corner of Horne Lake. The terrace decreases progressively in elevation from 500 feet above sea-level in the narrow channel section adjacent to Horne Lake to 450 feet along the broad northeastern periphery and, clearly, was deposited by a northeast-flowing river. Within the terrace is a large depression, 20 to 50 feet deep, with triangular outline and margins more or less parallel to the outer borders of the terrace. The depression is floored with knob-and-kettle gravels and is traversed by esker-like gravel ridges trending northeastward. Some of these ridges are connected to the terrace at their upstream and downstream ends .

The terrace is confined on the south by the steep mountain front and on the west by a low till-surfaced ridge. On the east it terminates in a steep scarp, 50 to 75 feet high, that separates the terrace from lower, marine-veneered ground-moraine country. Parts 


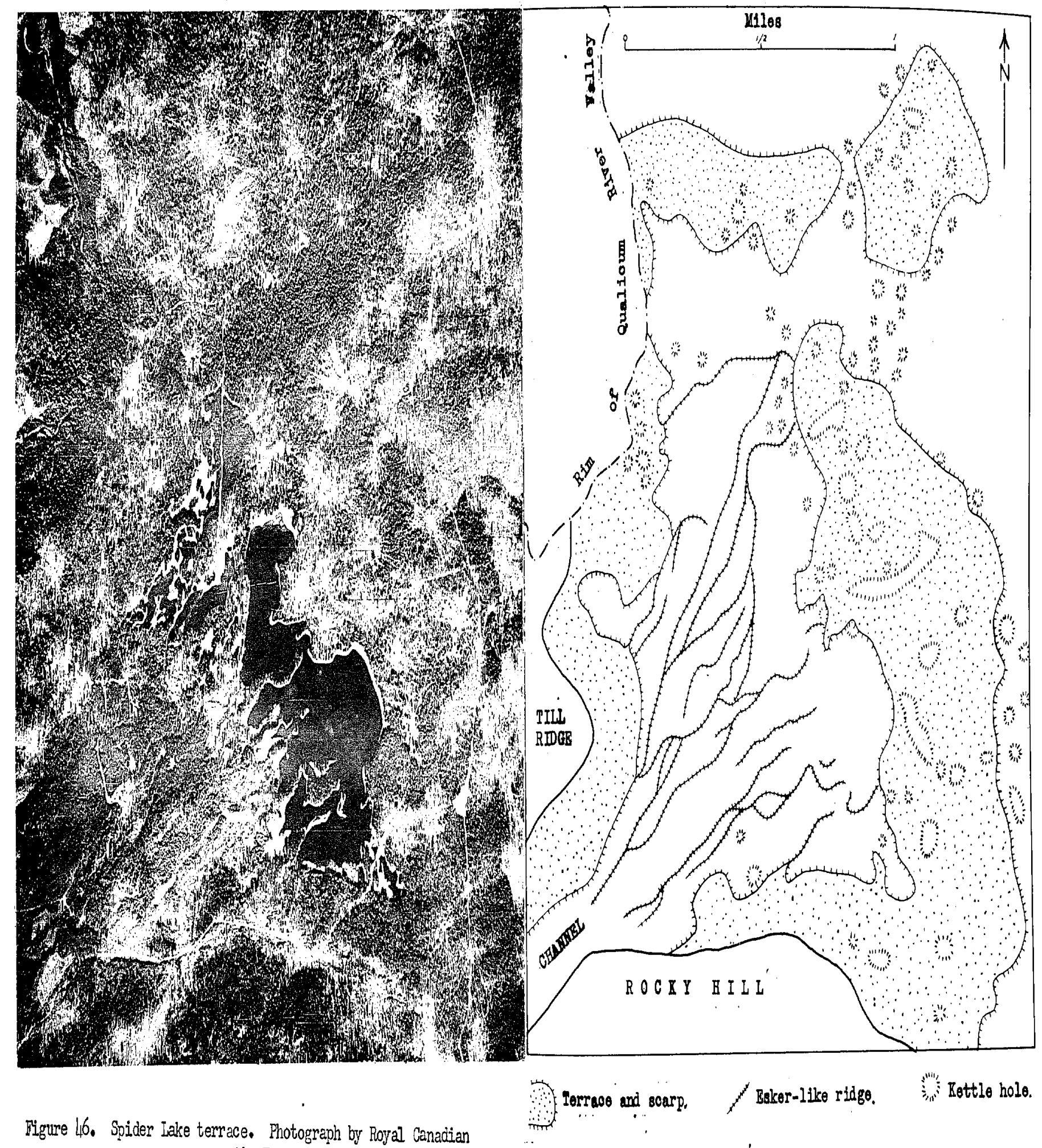
Air Force. 
of the scarp resemble the front fore-set slopes of nearby deltas but most of it presents an irregular scalloped outline and is indented by kettle holes. The semicircular area, shown on the accomparying geological map as marine-washed glaciofluvial material, extending a third of a mile east of from the terrace front due east of Spider Iake, is an area of humocky sand in which silt and clay (marine?) fill the bottoms of many depressions. The northern part of the terrace, north of the central depression, stands 20 to 30 feet above the eastern part of the terrace and is separated from it by a humocky zone in which neither terrace level is represented. The peripheral scarp bordering this northern part of the terrace is smooth and contains only rare, poorly defined kettle holes. This scarp, and a series of lower gravel and sand terraces to the north appear to have resulted from truncation and redeposition of the marginal parts of the kettled terrace by waves and currents.

The steep slope dropping off from the head of the Spider Lake terrace to Horne Lake is humocky and bears small kettle holes and narrow discontinuous terraces. One small terrace part way up this slope leads northwest around the hillside to a small abandoned stream channel that slopes down to the northwest and is cut off by the valley of Qualicum River.

The Spider Lake terrace and the steep slope separating it from Horne Lake are built of fairly well-rounded pebble and cobble gravel and pebbly sand. On the basis of depth of kettle holes, the 
deposits may locally exceed 50 feet in thickness. 10 to 20 per cent of the pebbles in the gravel consist of granodiorite, and, in this respect, the deposits are similar to the glacial materials of the coastal plain and are unlike those of Horne Lake Valley.

The Spider Iake terrace was built partly on the ground and partly on thin remnant glacial ice that melted to leave the large central depression and the kettle holes. If the ice-contact features of the peripheral northeast scarp are discounted, the terrace has the form of a delta that fortuitously buried or partly buried a remnant of glacial ice occupying the re-entrant between the mountain front and a north-projecting till ridge. The esker-like ridges probably outline successive positions of a river channel as it crossed this ice remnant. The ice contact features of the peripheral scarp, on the other hand, seem to indicate that the terrace complex is a kame terrace built against glacial ice that occupied the coastal lowland to the north and east. The contrast between the unmodified kettle holes and ice-contact irregularities along parts of the peripheral scarp and the smooth wave-modified form of other parts that would be no more exposed to waves and currents during submergence, seems to indicate that parts of the terrace front were exposed to wave attack while other parts were protected by glacial ice. On this basis, the terrace complex is inferred to be partly a delta built out into a water body and partly a kame terrace built against glacial ice. This ice may have been the broken frontal zone of a glacier ending in water, or 
individual, isolated glacial remnants, or perhaps merely grounded bergs. The delta sections of the terrace must have been built into a water body with surface between 450 and 500 feet above the present sea-level. The coincidence of this level with the limit of marine submergence in this part of the area is believed to be an indication that the Spider Lake terrace was built into the sea. The river that built the Spider Iake terrace seems to have left no channels or deposits west of the terrace itself. It might, therefore, be assumed that the river flowed out of an ice-darmed lake that occupied the Horne Lake ValJey. However, such a stream would not be carrying any load upon leaving the lake and, in the absence of extensive erosion along the narrow channel section of the terrace east of the lake, it could not have picked up any substantial load along its course and therefore could not have built the extensive Spider Lake terrace. Moreover, the hillside channel part way up the kettled slope below the head of the channel section of the terrace must have been formed by water flowing off the edge of glacial ice in the northeast bay of Horne Lake after formation of the Spider Lake terrace. Thus, the river that deposited the Spider Lake terrace can only have flowed across the Horne Lake depression on or within glacial ice. In view of the abundance of granodiorite pebbles in the terrace gravels, the river must have derived its load from glacial ice or till in the coastal lowland rather than from a source in Horne Lake Valley. It 
probably flowed along the southwest edge of the coastal pain on or within the marginal ice of a glacial body in the Georgia depression and may well have been the same river that deposited the Chef Creek-Hunts Greek kame belt. The course of the glacial river into the mouth of Horne Lake Valley and out again rather than by a shorter route across the valley mouth is an indication that an active ice tongue was not, at that time, flowing out of the Beaufort Range by way of the valley -

The small ice-marginal channel mid way up the kettled slope below the upstream end of the Spider Iake terrace cannot have been formed by the same river as the terrace. It rather appears to have been made by a smaller stream flowing out of Horne Lake Valley along the margin of the residual ice in the valley that had become separated from the ice in the Georgia depression. Still later, the present course of Qualicum River was established by drainage from thinner remnant ice in the Horne Lake depression and/or from a lake or lakes standing 50 feet or more above the present lake. The rare narrow terraces and fans along the valley walls 50 to 75 feet above the present lake and the more extensive terraces (some of them delta-like) about 2 miles w Horne River from Horne Lake probably date from this stage.

\section{Iittle Qualicum Ice-Contact Gravels}

Terraced and knob-and-kettle gravels, including deltalike forms similar to the Spider Lake terrace, occupy the mouth of the Cameron-little Qualicum Valley and adjoining parts of the 
coastal lowland. Knob and kettle gravels are abundant below an elevation of 1000 feet along Cameron-Iittle Qualicum Valley northeast of Cameron Lake, and narrow, discontinuous gravel terraces separated by belts of $\mathrm{knob}$ and kettle topography are found between 1000 and 600 feet above sea-level along the lower parts of the mountain front for $1 \frac{1}{2}$ miles northwest and southeast of the valley. The terraces along the mountain front characteristically slope downward from northwest to southeast.

A delta-shaped gravel terrace, 450 to 500 feet above sealevel and about a mile across, lies along the inland border of the coastal lowland west of Little Qualicum River. It is sumounted by isolated kames near the base of the mountain slope and is pitted by deep kettles. Its north boundary is a steep scarp, with irregular scalloped outline, that drops off 75 to 100 feet to a narrow belt of knob and kettle gravel and sand separating the terrace from an area of marine deposits. East of Iittle Qualicum River, the same terrace and arcuate pexipheral scarp extend east and southeast to the Alberni road at Whisky Creek. This eastern part of the terrace, however, does not extend southwest to the mountain front but rather forms a belt up to $\frac{1}{4}$ mile wide marginal to an area of kames and kettles (Figures 47 and 48 ) in which the highest summits approximate the elevation of the terrace surface. The steep terrace front east of the river, unlike that to the west, is smooth in outline, contains only rare, poorly defined kettles, 


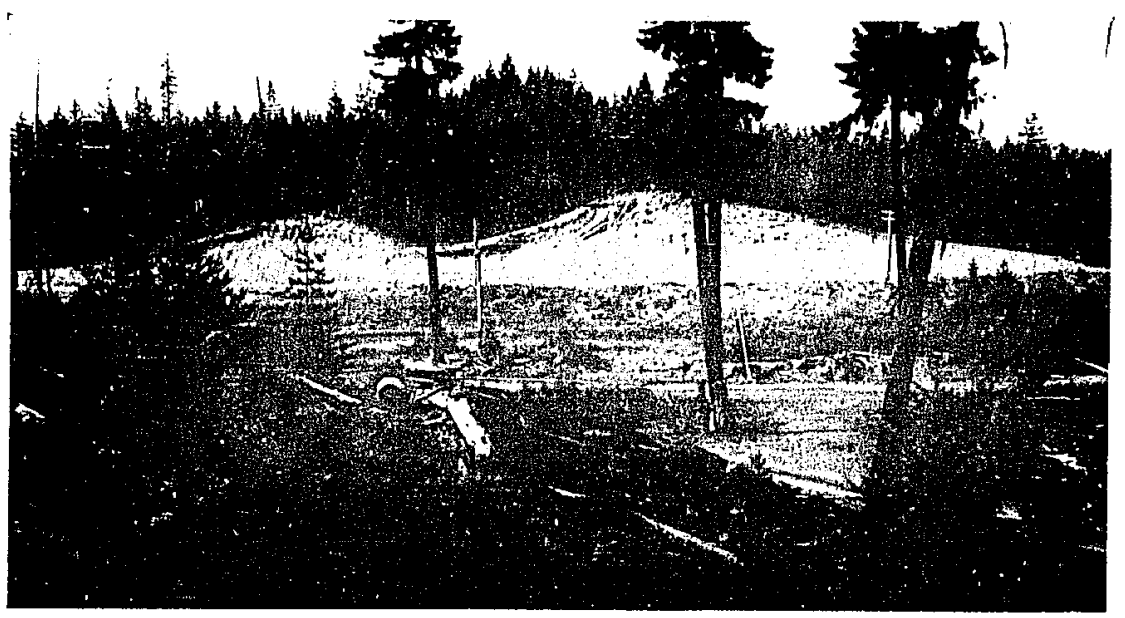

Figure 47. Topography of the kame and kettle area east of little Qualicum River; looking south across Alberni Highway half a mile west of Whisky Creek.

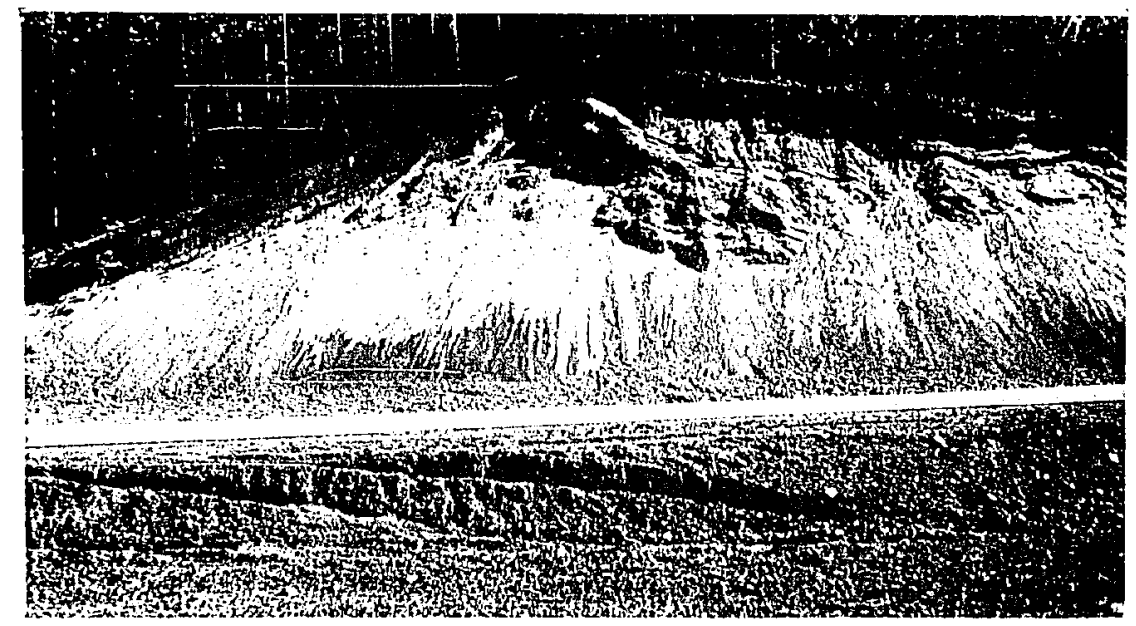

Figure 48. Closer view of kame illustrated in Figure 47, showing inclination and faulting of the constituent gravel strata. 
and locally bears tiny beach platforms. Midway along the scarp east of the river, an eliptical hill of gravel with summit elevation close to that of the terrace surface projects about $1 / 3$ mile to the north. Its northern face bears a series of welldefined beach terraces but, on the south, it is pocked by deep kettles. Southwest of this hill is a small delta, 30 feet below the main terrace and lying against its eastern margin, that narrows southwestward into a poorly defined, kettle-floored valley extending through the main terrace to the kame and kettle area beyond. Within the kame and kettle area are a few terracetopped hills about 550 feet above sea-level, and separating it on the south from the mountain slope is a fairly continuous terrace at about the same elevation. Possibly the 550-foot terraces and the 450 - to 500-foot delta-shaped terrace to the north are parts of a single sloping surface, but, more probably, they form separate levels. Both the 550-foot terrace and the kame and kettle belt extend about $2 \frac{1}{2}$ miles southeast from little Qualicum River. South of Hilliers the kame-and-kettle belt terminates in a gravel and sand delta that is about $3 / 4$ mile across and 450 to 500 feet above sea-lerel. Along its outer eastern margin, the delta surface grades imperceptibly, with no break in slope, into an area of marine sand. Westward, the terrace rises very gradually in elevation, becomes progressively more gravelly, and is pitted by an increasing number of kettle holes. Between this Hilliers icecontact delta and the delta-shaped terrace adjoining little 
Qualicum River, the kame and kettle gravels are bordered on the north by marine sand and probably, in their lower parts, have been modified by marine action.

These ice-contact deposits in and around the mouth of Cameron-Litt]e Qualicum Valley consist, typically, of well-sorted and rounded pebble and cobble gravel and pebbly sand, but some of the kame and kettle deposits include poorly sorted gravel, lenses of till, and boulders. In contrast to the sj.tuation at Horne Lake, pebble counts have not provided a basis for distinction of deposits of streams flowing out of the valley from those of streams originating in the coastal belt.

The narrow terraces and belts of kames sloping southeastward along the lower parts of the mountain slope near Little Qualicum River appear to be deposits of streams that flowed southeast abng successive margins of a glacial body in the Georgia depression. The kame and kettle gravels in the mouth of cameronLittle Qualicum Valley probably were deposited in part by these streams as they c rossed the valley mouth on remnant ice, and in part by contemporaneous or later streams flowing out of the valley. The 550-foot terrace along the inland border of the coastal lowland and the kame and kettle gravels bordering the terrace on the north form a kame terrace system that, like the adjoining higher termaces, seems to have been deposited by a southeast-flowing stream confined between the mountain front and a glacial body in the Georgia depression. The absence of this terrace northwest 
of the mouth of Cameron-Iittle Qualicum Valley provides a suggestion that the stream originated in the valley rather than on the coastal lowland to the northwest. At first, the stream must have been closely confined against the mountain front in the belt now occupied by the terrace and must have escaped to the southeast by an unknown course. Later, it flowed at a slightly lower level over discontinuous ice along the present kame and kettle belt and built the Hilliers ice-contact delta where the broken ice terminated in water standing between 450 and 500 feet above the present sea-level. The coincidence of this level with the limit of marine submergence and the gradation of the delta deposits into sand and clay similar to materials elsewhere containing marine shells are believed to be indications that the delta was built into the sea.

The 450 to 500-foot terrace straddling little Qualicum River is bordered by a fresh ice-contact scarp on the northwest and by a smooth wave-modified slope on the northeast. The northeast face would be no more exposed to wave attack during submergence than the northwest face, and therefore, like the Spider Lake terrace, this deposit is believed to be partly a kame terrace built against ice and partly a delta built into marine water. Its symmetrical outline relative to the Cameron-Little Qualicum Valley and its slope away from the valley mouth west of the river indicate that it was deposited by a stream flowing out of the valley. Probably it was built by the same stream that 
deposited the Hilliers ice-contact delta after progressive disintegration of the glacial ice had permitted the sea to penetrate westward along the northern edge of the kame-and-kettle belt as far as the present course of Little Qualicum River. Remnant ice must, nonetheless, have remained beneath the gravels in at least the western part of the kame and kettle belt to provide a bed for the stream that built the eastern section of the kame delta. Still later persistence of remnant ice in this part of the kame and kettle belt is evident in the relationships of the small delta 30 feet below the kame delta and bordering it on the east. This delta occurs at the mouth of a kettle-floored channel that disappears headward among the much deeper kettles of the kameand kettle belt. It was therefore builtbra stream that flowed over remnant ice and into a water body whose surface was about 30 feet below the water level during formation of the kame-delta. If both water levels were marine, then glacial ice must have remained buried beneath gravels of the kame-and-kettle belt during the (considerable?) time required for a change of 30 feet in the Iand-sea relationship.

The stream that deposited the Little Qualicum kamedelta and the terraces and kames on the coastal plain to the east may have been fed by meltwater from a glacial body filling the Cameron Valley or may have flowed out of a lake damed above the present level of Cameron Lake by remnant ice and/or ice-contact gravels in the valley mouth. 
Englishman River and Vicinity

- The country between the little Qualicum ice-contact deposits and Englishman River contains only small and poorly defined glaciofluvial and glaciolacustrine deposits. On the coastal plain, two small areas of hummocky gravel and sand that have been considerably modified by marine action occur south of Coombs. South of the coastal plain, narrow gravel terraces and small, irregular gravel hills are relatively numerous on the lower part of the mountain slope, but on account of their lack of continuity, they are not shown separately on the accompanying map. Because of their perched position on the hillside well above the coastal lowland, they most probably were deposited in streams or lakes impouned against the hillside by glacial ice. A few of them, indeed, are bordered by kettle holes or by irregular slopes that give the impression of being ice-contact faces, and a few of the terraces, sloping downward along the hillside from northwest to southeast, appear to be channels of streams that flowed southeastward between the mountain slope and glacial ice.

The belt of mountainside gravel deposits described above terminates at its southeast end in a kame field, 1200 to 1600 feet above sea-level, where the northwest side of Englishman River Valley meets the mountain front. Extending northeast down the mountain slope from this belt of kames is a multiple-crested esker, $2 \frac{1}{2}$ miles long, that crosses Englishman River at the falls and ends (cut off by a gully) on the coastal lowland about 500 feet above 
sea-level. Between Englishman River and South Englishman River are two similar eskers (see Figure 49) that apparently head on the lower mountain slope south of the map-area and that meet and terminate on the west side of the large gully occupied by South Englishman River, where they are dissected and buried by a terrace between 450 and 500 feet above sea-level. Esker remnants have not been found on the coastal plain to the north of any of these eskers. It is tempting to suggest that the eskers never extended much farther to the north and that their deposition (or non-deposition) was in some way governed by the $450-$ to $500-$ foot stand of the sea that appears to have been associated with the retreat of the ice in the Georgia depression, but, more probably, the coursies of the eskers to the north have been obliterated by marine and fluvial erosion and by the succession of marine deltas flanking the rivers. The esker that crosses Englishman River at the falls would seem to have been built by the stream that built by the higher terraces and kames along the mountain slope to the northwest and that, as inferred above, flowed southeast between the mountainside and glacial ice in the Georgia depression (ice surface 1500 to 2000 feet above sea-level?). Diversion of this stream upon reaching Englishman River Valley northeastward, parallel to the valley, to build the esker seems to indicate that the ice in the valley was not an inactive remnant but was actively advancing into the Georgia depression. The terrace between 450 and 500 feet above sea-level that 


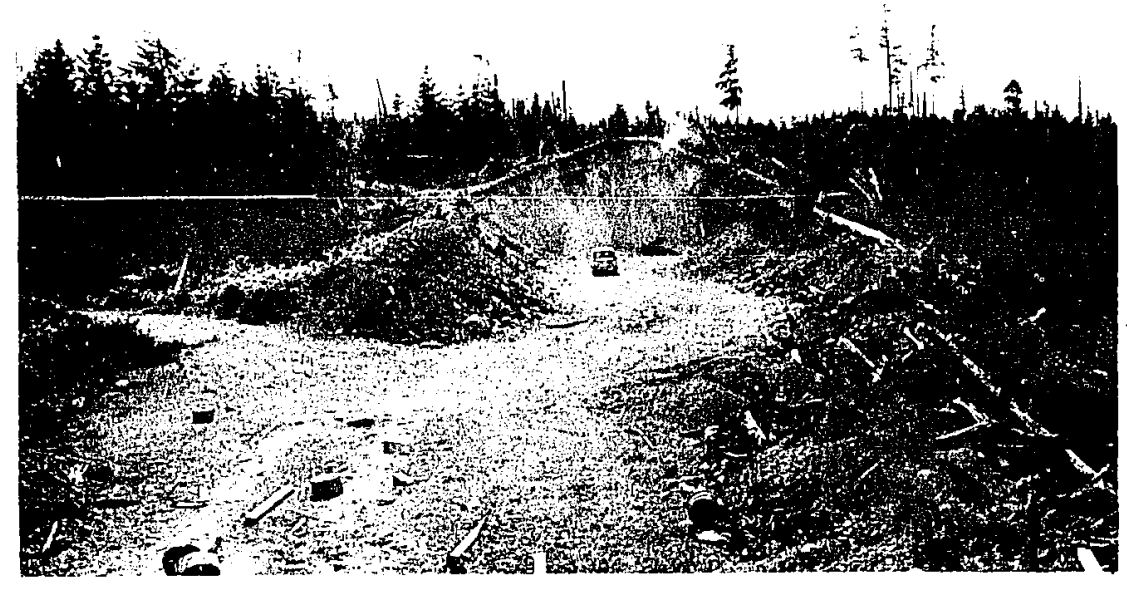

Figure 49. Gravel pit in esker ridge, south of South Englishman River. 
cuts off the eskers west of South Englishman River, and the terrace at the same elevation on the opposite side of the river together form the highest delta of a succession of marine deltas bordering the river. This delta differs from those at lower elevations in that it contains a steep-walled, kettle-floored depression a quarter of a mile across east of the river, and in that gravel knobs up to 30 feet high stand above the terrace surface west of the river. The gravel knobs are interpreted as remnants of the nearby eskers, that have been surrounded by the delta. The kettle-floored depression must have formed upon melting out of a glacial remnant or a large iceberg that had been buried by the delta gravels, and therefore this highest delta has been assigned to the glacial Vashon group.

Along Englishman River, terraces 450 feet above sea-level and higher are inconspicuous, thoroughly eroded, and have lost any ice-contact form that they may have originally possessed. On the other hand, the highest marine delta of any size (420 feet above sea-level) southeast of the river contains three isolated kettle holes a few feet deep and a few tens of feet across. The ice blocks that, presumably, melted out from within the gravels to form these pits may have been small pieces of berg ice that were buried by the delta as it advanced into the sea or pieces of local glacial ice carried into position by the river. In view of the absence of kettle holes from all other delta-terraces of the coastal lowland except those 450 to 500 feet above sea-level, it 
seems unlikely that bergs were generally distributed in the Georgia Strait while the 420-foot delta was being built. It seems likely, therefore, that some ice remained in Englishman River valley until the sea-level had dropped to the level of this terrace and supplied the ice blocks that melted out to form the kettles. GLACIAL LANDSLIDE

A landslide that left a prominent scar on the mountain scarp along the northeast side of Alberni Valley just north of Mount Joan has spread mibble 3 miles southward along the floor of the valley as far as the junction of Ash and Stanm Rivers. The relationships of this rubble to the glacial deposits, as outlined below, indicate that the slide must have come to rest on thin glacialice in the bottom of Alberni Valley.

The slide materials vary greatly in texture and sorting but are distinguishable from the other unconsolidated deposits of the valley floor because the contained stones are angular and consist exclusively of massive dark green trap and vein quartz. Some of the slide materials look more like fault breccia than anything else that the writer has encountered; others, containing much fine material, a re like glacial till; and some are fairly well sorted gravels. Isolated angular blocks 5 to 50 feet across are scattered about amid the finer rubble. As far south as the road extending west from the Alberni Pacific Lumber Company camp, the slide dposits are continuous and probably average more than 100 feet in thickness. This northern part of the slide 
surface is characterized by more or less conical hills 50 to 100 feet high consisting of blocky rubble. Angular blocks as big as a house are scattered between the hills and are perched on their slopes and sumits. South of this road the slide surface drops off steoply about 50 feet to a flatter area in which the landslide rubble is discontinuous and, for the most part, is less than 10 feet in thickness. In much of this lower area the slide deposits take the form of a featureless till-like veneer but in a few places they form conical hills up to 30 feet high. Iocally, the slide is represented only by isolated blocks of trap lying upon till and other glacial deposits.

An esker, trending southeastward, appears from beneath the landslide deposit about half a mile southwest of the Alberni Pacific Iumber Company camp. Slide material is not present where the esker crosses the north-south road about a mile south of the camp, but a quarter of a mile to the northwest up the esker from the road, isolated blocks of dark green trap up to 10 feet across are strewn about on the top and sides of the esker and on the surrounding ground moraine. Farther northwest the rubble on the esker surface becomes progressively more abundant until it completely veneers the pebbly esker gravel, although the form of the esker remains unmodified. The, rather abruptly, the landslide rubble develops a hummocky surface and thickens sufficiently to completely obscure the esker. About a mile north of the junction of the Ash and Stamp Rivers, adjoining the northwest-trending 
"Comox" road, are two small groups of conical gravelly hills 10 to 30 feet high that, in the discussion of the glaciofluvial materials, ace considered to belong to the esker system. Some of these are normal kames consisting of fairly well-sorted and rounded pebble gravel including a variety of rock types, but others are : built of angular landslide gravel made up of pieces of dark green trap including blocks several feet across. A road cut in one of the knobs surfaced with landslide-type gravel revealed a bed of round-pebble gravel containing a variety of rock types within about 5 feet of angular gravel composed exclusively of green trap. On the other hand, isolated angular blocks of dark green trap lie on the tops and slopes of some of the pebble gravel kames, and a small gravel pit on one of these kames encountered several such blocks. These relationships seem to indicate that the kames of pebble gravel and the linobs of slide gravel had a common origin. The landslide deposit lies upon the ground moraine and the esker and must therefore have been formed after the climax of the last glaciation of the area. On the other hand, the presence of slide blocks in the kame gravels indicates that the slide cannot have taken place after disappearance of the ice. Horeover, distribution of the blocks of slide material on the top and sides of the kames and esker rather than in the adjoining hollows, and the uniformity of thickness of the slide veneer on the esker, in the depression between the esker ridges, and on the adjoining ground moraine would be difficult to explain if the slide 
had spread over the ground rather than over the ice. Therefore, the conclusion is drawn that this slide came to rest on thin glacial ice during deglaciation, and as the ice melted, the slide materials became incorporated in some of the glacial deposits and were le $t$ down as a blanket on top of others.

Numerous Iandslide deposits are found below the steep valley walls of the mountainous parts of the map-area but the slide described above is the only one that has been demonstrated to have taken place during deglaciation. Nonetheless, the oversteepened hillsides would be less stable imnediately after being uncovered by the glacial ice than at any subsequent time, and, in the absence of evidence to the contrary, it seems probably that many of the landslide deposits were formed during or soon after deglaciation.

\section{GLACIOMARINE DEPOSITS}

Among the varied marine deposits overlying the ground moraine and glaciofluvial deposits of the Vashon group are stony clays and till-like materials that, apparently, were formed by mixing of sea-bottom mads with debris cropped by floating ice. The materials provide no indication whether this floating ice was glacial or whether it was sea ice, but if the climate of southerm Vancouver Island were cooI enough to produce appreciable quantities of sea ice, glacial bodies would also be discharging icebergs into Georgia Strait and Alberni Inlet. If, as inferred from the "kame deltas", the glacial bodies in both Alberni Valley and the Georgia 
depression terminated in marine water during deglaciation, extensive rafting by bergs and floating glacial tongues must have taken place. Therefore, some, and probably many, of the stony clays and till-like materials are believed to contain material rafted by floating glacial ice. On this basis, they are classified as glaciomarine and assigned to the Vashon group. They are associated both spatially and genetically with a wide varidy of marine deposits that are assigned to the Capilano group. Glear cut distinction of the marine, Capilano group materials from the glaciomarine, Vashon group materials has not been possible either in mapping or in description. Therefore, discussion of the nature and relationships of the glaciomarine deposits is included with the description of the marine deposits in the next chapter.

\section{GLACIAL MOVEMENTS MSSOCIATED WITH THE VASHON GROUP}

The record of the last glaciation is found in the ground moraine, ice-contact, glacial-landslide, and glaciomarine deposits of the Vashon group, described above, and in the erosional glacial features inscribed upon the bedrock of the region. In the following pages, information on glacial movements provided by glacial flow markings on the rock surfaces will be integrated with the information on the same subject derived from the Vashon drift (largely presented above) to outline the sequence and pattern of ice movements during the last glaciation. Most of the pertinent data are shown on Figure 50. 
Striae and related ice markings are clearly discernible on almost all glaciated rock surfaces that have been newly exposed by waves, rivers, and human agencies. Unfortunately, such surfaces are rare and the weathered, more or less moss-covered surfaces that comprise most of the bedrock exposures of the region reveal such indicators of glacial movement in only a few places. In logged area, on the other hand, striae and even grooves cut by slidings logs and cables simulate features of glacial origin. Such rock-inscribed features that are believed to be glacial flow markings are plotted on Figure 50. Stoss-and-lee surfaces, cragand-tail forms, and roches moutonnee are assumed to reveal the direction of movement of the eroding ice and are indicated on the map by a directional symbol, whereas striae and grooves are represented by a symbol showing merely trend or bearing.

It is assumed that most, if not all of the glacial flow markings shown in Figure 50 date from the la st glaciation. This inference is supported by the observation that the direction of the ice movement determined from stones in Vashon drift, wherever such determinations have been possible, is parallel to the nearby striae, grooves, etc. Moreover, glacial movements associated with the Dashwood group may well have been similar to those associated with the Vashon (see discussion of Dashwood till), and therefore inclusion of a fer striae etc. of the early glaciation with those of the last would probably not lead to radical inconsistencies. An entirely different interpretation, however, has 
been put forward by Clapp, who ascribed the glacial flow markings on the rock surfaces of southern Vancouver Island to his Admiralty glaciation, which appears to be equivalent to the Dashwood of this report (Clapp, 1914, p. 90-91; 1917, p. 351-352).

\section{Glacial Movement across the Mountains}

Glacial flow markings on the mountain crests of the area all appear to have been made by south- to southwest-moving ice. On the ridge crests of Beaufort Range, striae and grooves trend exclusively northsouth to northeast-southwest and associated stossand-lee surfaces and crag-and-tail forms in half a dozen places reveal south to southwest glacial flow. Outcrops on the summits of the range are glacially rounded and a roches moutonnee-like boss, shaped by the southwest-moving ice, was found only 10 feet below the summit of the highest peak (elevation 5109). Similar evidence of south to southwest glacial movement has been found on the ridges of Cameron Lake bordering Mount Arrowsmith but here the highest recorded striae and grooves, except in cirques, are only 4600 feet above sea-level. Above this elevation, although many outcrops are rounded and smooth, positive evidence of glacial cover outside the cirque basins has yet to be found. Rock outcrops on the summit ridge above an elevation of 5500 feet appear to be more deeply frost heaved disintegrated than on lower ridges. This difference may be due to increase in frost action with elevation but, may, alternatively, indicate that the sumit ridge 
of Mbunt Arrowsmith was not covered by the last ice sheet. The sharp arrete-form of the summit ridge, contrasting with the typical broader ridges at lower elevations, is in accord with the inference that the sumit stood above the ice as a nunatal, although its form certainly is partly due to undercutting by local glaciers in the flanking cirques.

The few published records of the direction of glacial movement on the mountain and ridge crests southeast of the map-area are in accord with the above observations. Thus, in the Cowichan Iake area, "Even the highest peaks are well rounded, and glacial erratics have been noted as high as 4700 feet above sea-level. Striae on tops of ridges are not well preserved, but on the ridge east of Mount Service, striae trend south to south 15 degrees west, and at an elevation of 4500 feet on the ridge at the head of the southwest fork of Nitinat River, striae trend south 10 to 15 degrees east. Stoss and lee surfaces indicate that the ice moved southward" (J. T. Fyles, 1955, p. 9). C. H. Clapp (1913, 1914, 1917) has recorded many striae in southern Vancouver Isl and but most of these represent valley and lowland ice movements. He has concluded, however, that ice moved southward across the uplands of the Sooke and Duncan areas.

Northwest of the map-area, the crest of the Vancouver Island Ranges is 1000 to 1500 feet higher than in the Beaufort Range. W. H. Mathews (personal communication) reports that glacial flow markings on the ridge tops of Forbidden Plateau in this high 
area all indicate northeast rather than southwest gla cial movement. Possibly the southward-moving ice never covered this high part of Vancouver Island although, on the basis of the meager evidence available, it is alternatively possible that late local ice caps (see discussion Alberni Valley ice movement) have destroyed the record of the southward-moving ice.

It is concluded from the above that, curing the climax of the last glaciation, ice from the Georgia depression (and probably emanating ultimately from the Coast Range) flowed southward across the mountains of the map-area. This ice completely covered Beaufort Range but probably never completely covered the isolated high ak of Mount Arrowsmith. The ice moving out of the Georgia depression also may never have buried the crest of the Vancouver Island Ranges northwest of the Beaufort Range.

Valleys Through the Beaufort Range

Glacial ice moved southwestward in the passes and valleys through Beaufort Range in the same general direction as the ice flow across the nearby ridge tops. Glacial flow markings in Cameron Valley, on the low divide between Cameron Valle $y$ and Alberni Valley, and on the low plateau south of Horne Lake vary in trend with the valleys and hillsides but record glacial movement from the Georgia depression towards Alberni Valley (see Figures 50 and 51). GF cial flow in this direction in Cameron Valley is also evident in the presence of abundant granitoid stones in till along 


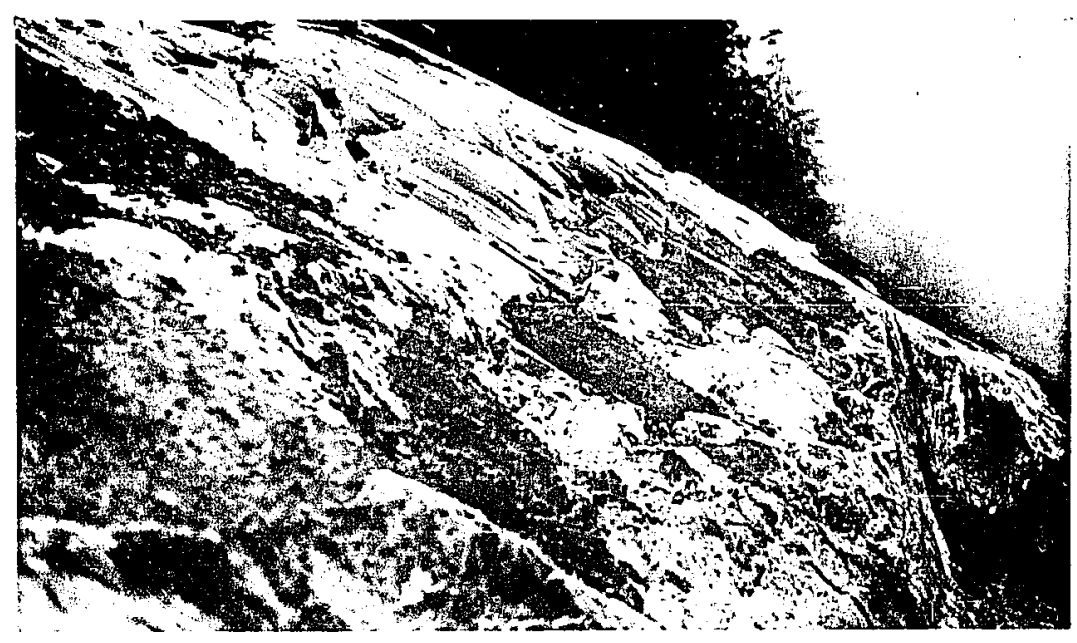

Figure 51. "Stoss-and-lee surfaces formed by ice moving diagonally up the west wall of Cameron Valley towards the low pass loading to Alberni Valley. Glacial movement right to left is indicated by the contrast between the grooved, rounded downhill ends of the bulges on the rock surface and the ragged uphill ends of the bulges, as well as by tiny crag-and-tail forms that cannot be distinguished on the photograph.

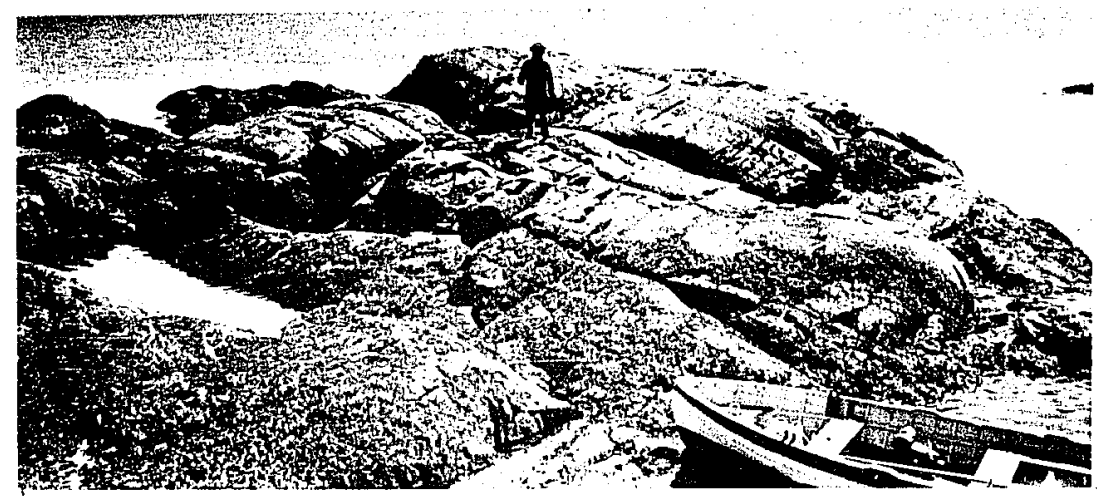

Figure 52. Rock surface deeply grooved and moulded by glacial ice flowing right to left (southeast), Balleans Islands.

\section{- Figure 50 appears in the pocket at the end of the dissertation.}


Gamer on Lake (see discussion of mountain tills).

Such southwest flow of ic e in these valleys would be expected to have taken place during the climax of glaciation while the ice extended across the mountains and ridges but also would be expected to have continued after the ice surface had dropped below the ridge tops and the main ice flow had been diverted along the mountain front bordering Georgia depression. Intersecting ice-movement indicators on the low divide between Cameron Valley and Albemi Valley appear to record changes in ice-flow direction with such changes in ice thickness. Here, grooves and crag-andtail forms made by southwest-moving ice are crossed by striae associated with stoss-and-lee surfaces indicating southward ice movement. A third set of striae trends east-west; this set less clearly appears to be inscribed on the southwest-trending grooves and the distribution of the striae on east encls of outcrops suggests movement from east to west. The earliest, southwest movement across this divide probably took place when the ice was thick enough to flow undeflected across the west wall of Cameron Valley. The southward movement may then have occurred after the glacial tongue had thinned until its direction of flow was controlled by the west wall of Cameron Valley but while it was thick enough to cut across the shallow east-west pass at right angles. The east-west striae probably were formed by the Cameron Valley ice moving west over the divide after further wastage. 
Girques and Cirque-Headed Valleys, Beaufort Range and Mount Arrowsmith

Cirques and associated valleys of the east side of the

Beaufort Range have yielded abundant evidence of up-valley glacial movements in the same general direction as the ice flow recorded on nearby ridges. In Rosewall Creek Valley, southward, up-valley glacial movement is abundantly recorded by stoss-and-lee surfaces and crag-and-tail forms on the valley floor and walls and by the presence of granitoid and sandstone pebbles (derived from the Georgia depression) in the till on the valley floor. Grooves and stoss-and-lee surfaces formed by this up-valley movement have been found on an outcrop a few tens of feet above the base of the steeply sloping valley headwall and also on the uppernost part of this heaciwall a few feet below the break in slope separating cirque from ridge crest. Similar evidence of southwestward, up-valley glacial movement has been found just below the top of the headwall of a cirque on the east side of the Beaufort Range south of lount Joan and in the mouth of the cirque-headed valley extending east and northeast from Mount Irwin. All these cirques and valleys undoubtedly were sculptured by local glaciers that moved northeast down the valleys, and the up-valley ice movements described above clearly took place after this sulpture. The flow of ice up the floors and steep heads of these valleys probably occurred mainly during the climax of glaciation while the surface of the ice stood above the ridge crests at the valley heads but perhaps may also have been found along the retreating ice edge after it 
dropped below the valley-head divicle.

Moraines and rock inscribed indicators of down-valley ice movement appear to be entirely lacking from those cirques and cirqueheaded valleys of the Beaufort Range that have been examined on the ground, and therefore active local glaciers (as opposed to ice sheet remnants) apparentIy have not occupied these valleys since the climax of the last glaciation. On the other hand, a cirque that was visited on the east side of Mount Arrowsmith (with floor 4500 feet above sea-level and 500 feet above the highest cirque floors of the Beaufort Range) contains roches moutonnee that record down-valley northeast ice movement of a local glacier. Evidence of southeast up-valley ice movement was not found in this cirque even though evidence of movement in that direction was found on neighbouring ridges. Apparently then, the snow line at some time during or since deglaciation was low enough for the existence of active glaciers around the Mount Arrowsmith Massif, but at no time since the climax of the last glaciation has it been low enough to permit active glaciers to develop on Beaufort Range.

\section{Glacial Novement in Georgia Depression}

Despite the abundant record of southwest movement of ice from Georgia depression across the mountains of Vancouver Island, evidence of ice movement in the same direction within the Georgia depression itself has been found in only a few places and the best-recorded glacial flow in the depression was southeastward more 
or Ie ss parallel to the mountain front.

Gla cial flow markings have been found in only the northwest and southeast parts of the coastal lowland of the map-area, the only sections where outcrops are abundant. The most abundant striae and grooves trend southeast to east-southeast in the northwest part of the lowland and east to east-southeast in the southeast part (see Fịgure 50). Stoss-and-Iee surfaces and roches moutonnee provide abundant evidence that the associated ice flow was southeastward. Surfaces of this type are especially prominent on Ballenas Islands (see Figure 52) and on Winchelsea Islands. Correlation of this southeast movement with the Vashon group is supported by the southeast trend of some of the fabric orientations that have been determined for Vashon group tills and by the presence of stones derived from a distinctive granodiorite bodies near Courtenay (northwest corner, Figure 50) in Vashon group tills as far southeast as Bowser (centre, Figure 50). All published information on direction of glacial movement in adjoining parts of the Georgia depression (Bancroft, 1913; Clapp, 1914; McConnell, 1914) concurs that the ice flowed southeast.

Striae trending north-south to northeast-southeast have been found in a few places in both the northwest and southeast outcrop areas of the coastal 1owland. Evidence that the associated glacial movement was southward is provided by crag-andtail forms on Cottam Point (east of Northwest Bay), by stossand-lee surfaces about a mile south of Mrad Bay, and by crag-and- 
tail forms on conglomerate on the mountain slope bordering the lowland near the head of Cowie Creek (see Plate I for geographic. locations). Inscribed upon these crag-and-tail forms at Cowie Creek, and therefore younger than the southward glacial movement, are striae averaging north 75 degrees east that parallel another set of crag-and-tail forms indicating eastward ice movement and that, in turn, may be equivalent to the abundant southeasttrending features of the coastal lowland. Association of northsouth glacial movement with some Vashon group tills of the coastal lowland is suggested by fabric orientations (see discussion of "type" tills of the Vashon group); the stones in these tills have come from sources in the Georgia depression, and hence the associated glacial flow ias southward.

The rare and isolated indications of south to southwest glacial movement in the coastal part of the map-area (listed above) may possibly record a general movement of ice across the Georgia depression whose effects have been largely obscured during later southeast ice movements along the depression. If so, the southto southwest flowing ice sheet that covered the Vancouver Island mountains may have been fed by ice moving in more or less the same direction across the Georgia depression from the Coast Range. The more abundantly recorded southeast mor ement of the Strait of Georgia gla cier (Dawson, 1890, p. 29) would then have resulted from diversion of the south-moving ice along Georgia depression when the ice had become too thin to push across the 
Vancouver Island mountains. On the other hand, the proportion of granitoid stones in tills of the coastal lowland is lower than would be expected if there had been very extensive southward glacial flow across the Georgia depression from the Coast Range. Hence, the isolated records of south to southwest ice movement in the Georgia depression may, alternatively, have no regional significance but merely reflect local diversion of the southeastflowing ice. If this is true, ice in Georgia depression throughout the last glaciation may have flowed dminantly southeast along the depression, and the southward movement of ice across the Vancouver Island mountains would then have been merely a lateral overflow of the southeast-moving Strait of Georgia glacier. The truth probably lies somewhere between these two extreme interpretations. The coastal lowland adjacent to Englishman River has been overridden by an ice tongue moving northeast out of Inglishman River Valley in addition to the southeast- and (?) southmoving glacial bodies discussed above. This northeastward ice movement is recorded by crag-and-tail forms on conglomerate on Iittle Wountain and al ong the old Alberni road a few hundred feet east of Englishman River. It is also recorded by the localized distribution of granodiorite-rich till and till-derived gravels between Englishman River and Nanoose, and by the north to northeast fabric orientation of granodiorite-rich tills (see discussion of Vashon tills of coastal lowland, and Figure 50). Near the coast, only the uppermost part of the Vashon till (now 
represented mainly by wave-washed lag gravel veneering the till) is rich in granodiorite stones, and therefore, the northeast ice movement here occurred late in the last glaciation. In the pages dealing with the eskers on the coastal lowland near Englishman River, the suggestion has been made that the westernmost esker was formed by northward diversion of lateral drainage of the Strait of Georgia gla cier by an active tributary glacial tongue flowing out of Englishman River Valley. It follows that this ice tongue caused northeast ice movement in the adjoining parts of the Georgia depression late in deglaciation. The ice moving out of the valley must, logically, have been fed by a mountain glacier heading on the east side of Mount Arrowsmith. This conclusion is supported by the evidence, presented earlier, that local glaciers existed in cirques of the Mount Arrowsmith Massif at some time during or since deglaciation.

\section{Glacial Movement in Alberni Valley}

Southeastward flow of glacial ice along Alberni Valley and eastward movement of ice into the valley from its western tributaries is recorded both by glacially moulded forms and by lithology of the drift. Evidence of the southwest gla cial movement characteristic of the Beaufort Range has been found only the southeast part of Alberni Valley adjacent to the low passes through the Beaufort Range.

In the northern part of Alberni Valley, drumlinoid ridges 
reveal convergent southeast, east and northeast ice movements (see Figures 38 and 50). The southeast-trending ridges are associated with clay-loam till containing few granitoid stones and indicate glacial flow along the northeast side of Alb erni Valley, whereas, the east- and northeast-trending forms are developed on granodiorite-rich, sandy-Ioam till and record the fl.ow of glacial ice out of tributary valleys to the west. In one place, the western till was seen to rest upon the eastern till but no evidence was found of a significant time lapse between their deposition.

The same pattern of gla cial movements has been found southeast of the crumlinoid zone. In the eastern, drift-floored part of the valley, southeast gla cial flow is recorded by a few striae and stoss-and-lee surfaces as well as by the low granodiorite content and high sandstone content of the till. In the western part of the valley, most striae and grooves trend east, east-northeast, and east-southeast, and, together with associated stoss-and-lee surfaces, incicate a fanning-out of ice into Alberni Valley from Great Central and Sproat Valleys. Ice flow out of Great Central Valley is also recorded by small crag-and-tail hills southeast of the east end of Great Central Lake and, farther north, by northeast-trending drumlinoid ridges at Moran Lake. On the other hand, striae in a few places in this western part of Alberni Valley appear to have been formed by ice moving southeast 
down the valley. On a hill trest of Stamp River about a mile upstream from its junction with Ash River, roches moutonnee formed by southeast-moving ice bear striae trending north 80 degrees east on their testern sides but not on their eastern sides. This relation of striae to roches moutonnee suggests that, here, eastward movement of ice from Great Central Valley took place after southeast movement down Alberni Valley.

Evidence of the direction of glacial flow on the steep northeast wall of Alberni Valley has been found only near its southern end between Bainbridge and Rogers Creek at elevations of less than 1500 feet. On this section of the valley wall, striae trending southeast have been found in several places. In one place on the plateau surface a few hundred feet east of the top of the valley wall, striae trending southeast intersect another set of striae trending south-southwest (Figure 50). Farther from the valley wall, all striae etc. have been formed by south- to southwest-moving ice and no evidence was found that the southeastflowing Alberni Valley ice extended far beyond the valley rim. Both southeast and southwest glacial movements seem to be represented on the southeast part of the flloor of Alberni Valley east of Alberni and Port Alberni. Characteristically, 10 to 15 per cent of the pebbles in the tills of this part of the valley are composed of granodiorite and probably came from the northwest, but a few tills contain isolated pieces of purple chert, chlorite 
schist, and crystalline limestone that outcrop only to the east and northeast. Intersecting sets of striae trending north 60 degrees east and south 70 degrees east have been found on an outcrop in the south part of Port Alberni and may indicate that both the southeast and southwest glacial movements crossed this part of the area. Nothing is known of the relative age of these two glacial mar ements.

As discussed on a previous page, the crest of Beaufort Range bears abundant evidence of south- to southwest-flowing ice. No evidence has been found of deflection of this ridge-top flow by ice from the northwest or west, and therefore the south- to southwest-flowing ice must also have crossed Alberni Valley curing the climax of gleciation. The absence of any evidence of glacial flow in this direction on the floor of Alberni Valley in the lee of the high part of Beaufort kange may possibly indicate that only the upper part of the ice moved southwest while the basal ice was stationary or, perhaps, flowed southeast. As the ice surface dropped below the crest of Beaufort Range, the southwest flow of ice across Alberni Valley must have ceased except near Alberni and Port Alb erni where ice would have continued to enter the valie $y$ through the passes occupied by Horne Lake and Cameron Lake. The glacial ice that flowed into Alberni Valley from the west to feed the southeast-flowing Alberni Valley glacier cannot have been related to the Strait of Georiga ice that fed the southwest ice flow discussed above but must have emanated from an ice 
centre to the northwest, probably on the uplands of Forbidden Plateau. The east and southeast pattern of flow into Alberni Valley from this centre probably was initiated upon cessation of the southwest glacial movement across the Beaufort Range when most of the country was still under ice but apparently continued while the ice thinned and became separated into a system of valley glaciers. Discussion of these events is included in the outline of deglaciation in the following pages.

\section{OUTLIINE OF DEGLACIATION}

Three glacier systems that emanated from different areas of accumulation occupied the map-area chring and after the climax of the last glaciation. Most extensive was the Strait of Georgia glacier system, which was fed by ice emanating principally from the Coast Range. Ice in Alberni Valley and its tributaries was fed by an ice cap that centered on the Vancouver Island mountains northwest of the map-area. An independent valley glacier system occupied Rnglishman River Valley and the cirques on the east side of Mount Arrowsmith. Both the Englishman River glacier and the ice cap northwest of Alberni Valley supplied ice to the Strait of Georgia glacier.

\section{Strait of Georgia Glacier System}

Ice of the Strait of Georgia system, during its maximum stand, covered the entire map-area except the sumit of Mount Arrowsmith. Then, as the surface of the ice became lower, the 
crest of Beaufort Range and of the ridges surrounding Mbunt Arrowsmith cat off the southward flow of the Strait of Georgia ice across this part of Vancouver Island except in valleys through the mountains occupied by Cameron Lake and Horne Lake. Ice in the valleys heading on the east side of Beaufort Range apparently ceased active movement as the ice le vel dropped below the level of the valley heads and, with further lowering of the ice-surface, the ice in Cameron Lake and Horne Lake Valleys Iikewise became stagnant. Alluvial fans were built against the edges of these waning ice tongues by mountainside streams. Rivers flowing along the ice margins and small lakes ponded by the ice made small terraces along the valley walls. It would seem likely that the ice in these mountain valleys would have melted sooner than the much larger glacial mass in the Georgia depression but evidence that this occurred seems to be lacking. Ice certainly remained in Horne Lake Valley until after construction of the Spider Lake terrace, when ice in adjoining parts of the Georgia depression was breaking up. This conclusion is based upon the inferred course of the river that built this terrace and upon the presence of an abandoned stream channel that flowed along the edge of glacial ice in the northwest bay of Horne Lake after formation of the terrace (see discussion of glaciofluvial deposits).

Changes in the southwest edge of the Strait of Georgia glacier are evident in ice contact features along the southeast edge of the coastal lowland and along the lower part of the bordering 
mountain slope. These features record the courses of streams that flowed off the land and southeastward along or near the lateral glacier margin. Ice marginal delta-like forms appear to mark the terminal edge of the glacier and to indicate that this ice margin was bordered by marine water standing 450 to 500 feet above the present sea-level. The distribution of these varied ice contact forms points towards progressive lowering of the lateral ice margin and northward recession of the terminal margin.

Ice-contact alluvial fans along the mountain slope at the head of Chef Creek and McNaughton Creek outline a glacial margin about 1500 feet above the present sea-level and sloping downward to the southeast. A single lower ice-contact fan apparently accumulated against a later ice margin about 1200 feet above present sealevel. The streams draining from these fans flowed southeast along the ice margin and, at one stage, a stream from the southeast end of the belt drained northward (beneath the ice?) to form an esker. This esker ends in a belt of knobby ice-contact gravel that trends southeast parallel to the direction of glacial movement and that appears to have been deposited by a river system flowing southeast in a series of crevasses. This river system was initiated before the ice surface dropped below an elevation of 1000 feet and apparently continued to flow until the ice surface stood below 700 feet.

The Spider Lake terrace, in the mouth of Horne Lake Valley, is interpreted as a deltaic body built partly in marine water standing between 450 and 500 feet above the present sea- 
level and partly around and against remnant glacial ice. The river that deposited this terrace headed on or within the Strait of Georgia ice to the northwest and crossed the north part of Horne Lake Valley on ice. This may have been the same river that deposited the belt of kames on the coastal lowland to the northwest. On the basis of the above interpretations, the Spider Lake terrace marks the southwest end of a terminal margin of the Strait of Georgia glacier. This ice edge seems to have been bordered by a series of glacial remants separated by marine water.

Ice contact features near Little Qualicum River record earlier events and changes along the southern margin and terminal edge of the Strait of Georgia glacier similar to those described above. Kame terraces, kames, and hillside channels on the lower part of the mountain slope northwest and southeast of Little Qualicum River and in the mouth of Cameron-Little Qualicum Valley appear to have formed in streams that flowed southeast al ong successive margins of the Strait of Georgia glacier as the level of the ice dropped from an elevation of about 1200 feet to 600 feet. Much more extensive terraces along the inland margin of the coastal lowland 550 to 450 feet above present sea-level were deposited by a later, lower ice-marginal stream that flowed out of Cameron-Little Qualicum Valley. Initially, this stream flowed southeast along the base of the mountain slope but later it found a course east from the valley mouth across remnant ice and built a delta at an ice-sea margin south of Hilliers. Another 
delta-like body, straddling Little Qualicum River, seems to have been built by the same stream partly against ice and partly into standing water at another later position of the ice-sea margin. These delta-like forms, like the Spider Lake terrace, are interpreted as marking positions of the terminal margin of the Strait of Georgia glacier and provide further evidence that the ice ended in a broken zone in marine water between 450 and 500 feet above the present sea-level.

\section{Inglishman River Glacier}

Southeast of the features described above, a glacier occupied the valley of Englishman River and flowed into Georgia depression during the deglaciation interval. Eskers on the lowland and the lower parts of the mountain front near Englishman River are believed to relate to the Englishman River ice tongue. One of these eskers heads in a field of kames on the mountain front 1500 feet above sea-level northwest of Inglishman River Valley. The kames appear to have been formed by a southeastflowing stream at the edge of the Strait of Georgja glacier and, if this inference is correct, the Englishman River glacier coalesced with the Strait of Georgia glacier while the surface of the latter stood at an elevation of 1500 or 2000 feet. It is not known whether the Englishman River gla cier continued to flow into the Georgia depression after the Strait of Georgia had retreated to the northwest. The presence of a large ice-block hole in a delta between 450 and 500 feet above present sea-level along 
South Finglishman River suggests that here, as to the northwest, the retreating gbcial terminus was bordered by the sea. Evidence that glacial ice remained in Finglishman River Valley south of the Georgia depression after sea-level had dropped to 420 feet above its present position is provided by kettle holes in a delta at this elevation bordering Englishman River.

\section{Alberni Glacier System}

Deglaciation of Alberni Valley was controlled by the regimen of a system glaciers emanating from the high uplands of Vancouver Island to the northwest. Initially, this ice probably an ice sheet that covered most of the country and in which direction of glacial flow was controlled by topography. Then, as the ice thinned, it split into separate east-moving valley glaciers that coalesced to form a southeast-flowing glacier in Alberni Valley. The Alberni Valley glacier and its western tributaries continued to be active and contimed to coalesce even when the ice became very thin. Support for this conclusion is provided by the southeast-trending esker system in Alberni Valley, which splits headward into tributaries trending southeast, east-southeast, and east parallel to adjacent drumlinoid ridges formed by the Alberni Valley glacier and by one of its western tributaries. Convergence of glacial ice from the several tributary valleys has $k$ ad to marked differences in lithology of the various Alberni Valley tills. Superposition of tills of different lithology records changes in 
the relative activity of the Alberni Valley glacier and its tributaries, but details of these changes are not known. Some of the complexities of the till and of the recorded directions of glacial movement may possibly have resulted from readvance of one or other of the tributary glaciers into Alberni Valley after break up or retreat of the Albermi Valley glacier, but clear cut evidence of such advances has not been found.

The glaciofluvial features of Alberni Valley indicate that the ice disappeared first from the southeast part of Albermi Valley and provide a suggestion that the ice margin retreated northeastward up the valley. An ice-contact stream that flowed eastward from Sproat Valley along the south end of Alberni Valley is recorded by an abandoned channel and by small kame terraces west of the head of Alberni Inlet. During the existence of this stream, the narrow valley occupied now by Alberni. Inlet cannot have been blocked by ice above the level of the stream bed. The approximate coincidence of the elevation of this stream bed with the limit of marine submergence may be an indication that the sea occupied the Alberni Inlet Valley at this time. Possibly the sea also extended into the southeast corner of Alberni Valley. As discussed at length in connection with the glaciofluvial deposits, ice contact gravels outline the course of a river that flowed eastward from the mouth of Great Central Valley over and around remnant glacial ice and that probably terminated midway across Alberui Valley in marine water 300 feet above sea-level. At this stage, 
the west part of Alberni. Valley north of Great Central was occupied by ice. The margin of this ice is believed to have retreated northward and for a brief period dammed a lake north of the Great Central gravels in the northward-oraining part of Stamp River Valley. In the east part of Alberni Valley north of the features described above, is southeast-trending esker system. that teminates in a kettled terrace about $1 \frac{7}{2}$ miles north of Stamp Falls. This terrace is also about 300 feet above present sea-level and may be a delta that formed where the esker stream flowed out of its ice-bordered channel into the sea. It represents a position of the ice margin in the east part of Alberni Valley close to that outlined in the west part of the valley by the Great Central ice-contact features. Therefore, the esker and the Great Central terraces may have been formed more or less contemporaneously. During their fornation, Alberni Valley to the south of Stamp Falls and east of Stamp River must have been free of ice while the bottom of Alberni Valley northwest of Stamp Falls was occupied by continuous ice and the region adjacent to the outlet of Great Central Valley contained remnant ice masses. Concurrently, at the head of the esker system, ice was probably still actively flowing southeast along Alberni Valley and east into Alberni Valley from west of Dickson Lake.

AGE AND CORRETATION OF THE VASHON GROUP

The last glaciation of Vancouver Island would be expected 
to have taken place during the Wisconsin Age and, therefore, the Vashon group of the map-area is considered to be Wisconsin. A radiocarbon dating showing that retreat of the Vashon ice sheet from Stillwater, Washington, took place about 12,000 years ago (Broeker and KuIp, 1955) provides a more concrete indication that the Vashon glaciation of the Puget lowland took place during the Wisconsin. Substages have not been recognezed within the Vashon group of the map-area and it is not yet known which of the named substages of the Wisconsin (Tazewell, Cary, etc.) are represented or whether, indeed, significant advances and retreats of the glacial margin in the region coincided with these substages. The glacial ice that deposited the Vashon group certainly must have extended far beyond the limits of the map-area and probably affected the entire Georgia depression. Therefore, it seems reasonable to correlate the Vashon group of the area with the glacial deposits to which the name Vashon has been applied in southern Vancouver Island (Clapp, 1913, 1914, 1917,) and in the lower Fraser Valley (Burwash, 1918; Johnston, 1923; Armstrong and Brown, 1953). On the same basis, the Vashon group appears to be equivalent to the Vashon deposits of the Puget lowland. More detailed correlation of the individual deposits of the Vashon group in the map-area with the individual glacial deposits in these other areas is not attempted here. 
CHAPTER 8

CAPIJANO GROUP

\section{INTRODUCTION}

Marjne and fluvial deposits form the suxface materjals throughout much of the coastal lowland and the floor of Alberni Valley, whereas stream terrace deposits, terraced alluvial fans, raj sed lake deposits, and old landslide and tulus deposits are found in the mountainous parts of the area. These deposits, which record former higher stands of the sea, lekes, and streams, or constitute gravity accumulations that have been inactive for many years, comprise the Capllano group as used in this report. The name Capjlano is taken from a district north of the City of Vancouver where deltaic and marine deposits are extensively represented; its geological application to deposits of this type was originally suggested by Dr. J.E. Armstrong of the Geological Survey of Canada (Armstrong and Brown, 1953).

On the coastal lowland, marine and fluvial deposits of the Capllano group rest upon "type" till of the Vashon group, and thus the Capilano group belongs at the top of the "standard" stratigraphic succession to which tine Vashon, Quadra, and Dashwood groups have been tied. In keeping wi th the group classification outlined in Chapter 3, the Capjlano group is defined as non-glacjal deposjts that succeed the glacial deposits of the Vashon group. If the Capilano group were to be strictly analagous to the older groups it should include all deposjts that have accumulated since retreat of the Vashon jce, but because of the special posjtion in our environment of the modern deposits that are presently forming, these are assigned to a separate group to 
which the name Sall sh is applied. The Sallsh group includes deposits that have formed and are still being formed at the present stand of the sea, lakes; and streams, and in extsting swamps, as well as slope deposits that are still active, whereas the Capjlano deposits have been left stranded by lowering of sea or lake level, down cutting of streams, or cessation of mass movements. On the accompanying charts, the Sali sh and Capjlano groups are described briefly as "deposits that are presently belng formed" and "deposits that are no longer being formed." The fundamental distinction is that the Saljsh deposits are classified as deltas, beach ridges, and so on by definition, whereas the Capilano deposits can be classifjed as "fossil" deltas, "fossil" beach ridges, etc. only on the basjs of geological inference. This distinction of Capilano and Salish deposits reflects neither li thology nor environment. Nor does it record a particular time except in the case of deposits graded to the sea shore, in which the divisjon coincides with the establishment of the present stand of the sea.

The Capjlano deposits of the mountainous part of the area consist of separate, small, and varied bodies that in the present study, have not been integrated into an overall succession. They are treated only incjdentally in this report. The lowland deposjts of the Capjlano group, on the floor of Albernj Valley and in the coastal part of the map-area, relate to former stands of the Strajt of Georgja and Albermi Inlet and consist of successive river floodplain deposits, deltas, marine-shore deposits, and sea-bottom deposits. The sea apparently stood at its highest position relative to the land during 
deglaciation, when it reached an elevation of 500 feet on the coastal lowl and and 300 feet in Alberni Valley. Most of the lowland Capilano deposits record progressive lowering of sea-level from this maximum ol though some evidence has been found of an interval of sea-level rise following recession of the sea to about its present level. Among the abandoned marine deposits of the area are stony clays that are believed to have been formed by mixing of sea-bottom mads with debris rafted by floating glacial f ce during deglaclation. For the purposes of the present report, these materials are classifjed as glaciomarine and are assjgned to the Vashon group rather then the Cepilano. For conventence, they are included with the marine deposits in the following di scussions.

\section{DEPOSITS OF THE COASTAL LOWLAND}

Below an elevation of about 500 feet, depressions and flat areas in the ground-moraine surface of the coastal belt are floored by accunulations of marine and glaciomarine materials of clayey, loamy, and sandy textures. Adjoining hilly and sloping parts of the lowland bear a thinner veneer of dominantly gravelly materials that eppear to have formed along successive marine shorelines. Streams crossing the lowland are bordered by successions of small gravelly deltas that clearly were formed at the same time as the marine accumulations and marine veneer. In a. few places, terraced fluvial deposits extend upstream from the deltas. 


\section{Marine Accumulations (Including Glacjomarine Deposits)}

\section{Nature of Deposits}

As shown on the geological map (Plate I) clayey, loamy (silty), and sandy marine materials cover large parts of the coastal lowland. These deposits average about 10 feet in thickness but locally exceed 25 feet. In most places, clayey materials make up the greater part of the marine succession while sands and loamy materials form discontinuous and thinner layers on top of the clay. The sands as well as the heavier-textured materials are of broed extent. Their surface is horizontal or gently sloping and is not marked by ridges or other beach forms. Shells of marine organjams or casts of such shells have locally been found in these materials. Separating the clayey marine materials from the underlying till are lenses up to 3 feet in thickness of sand, silt, clay, and gravel that have yjelded no marine shells.

The clayey phases of the marine deposits of the coastal lowland consjst cominantly of clay and silty clay but also include more stony till-like deposits. Some of the clayey materials have no apparent stratification, whereas others display indistinct to moderately prominent bedding planes outlined by slight changes in texture, by silty, sandy, or stony layers, or by concentrations of shells. Above the water table the clayey materials are yellow'sh-grey and hard and display blocky to columnar jointing. The fresh, unoxidized clays, on the other hand, are grey, soft, and sticky and some of them are very weak and unstable. Marine shells and black feticl organic matter 
are locally contained in the unoxidized material but only casts and molds of the shells of the shells remain in the oxidized surface material. A black irridescent film that probably consists of manganese dioxide coats the fracture surfaces of the oxidized clays. The clays and silty clays are essentially poorly sorted mixtures of clay- and silt-size particles in approximately equal proportions but contain isolated stones and a few per cent of sand. Mechanical analysis data for 5 sarmples are presented in Table III. These clays and silty clays are very similar to those of the Dashwood group (see Chapter 5 and Figure 17) but, on the average, are less stony than the Dashwood materials. The till-like materials are more sandy and more stony than the clays and silty clays and display a wide range of textures. They include gravelly sandy loam, gravelly loam, gravelly silt loam, gravelly clay loam, and gravelly silty clay loam. Generally, they are slightly more clayey than the underlying till, and, in the unoxidized state, they are less dense and contain more water than the till. Loany materials are associated with some of the clays and silty clays, and, in places, are transitional between clayey and sandy beds. These loamy materials are massive to indistinctly stratified, grey in fresh exposures, and brown to grey-brown in typical nearsurface exposures. Casts of marine shells are widely distributed in them. They are moderatay well-sorted mixtures of silt and very fine sand or silt and clay and include very fine sandy loam, loam, silt loam, silt, and silty clay loam. They are designated on the accomparying geological map (Plate I) simply as silt. Mechanical analysis data for two samples is presented in Table III. 
TABLE III

GRAIN-SIZE DATA FOR CLAYEY AND LOAMY MATERIALS OF THE CAPILANO GROUP

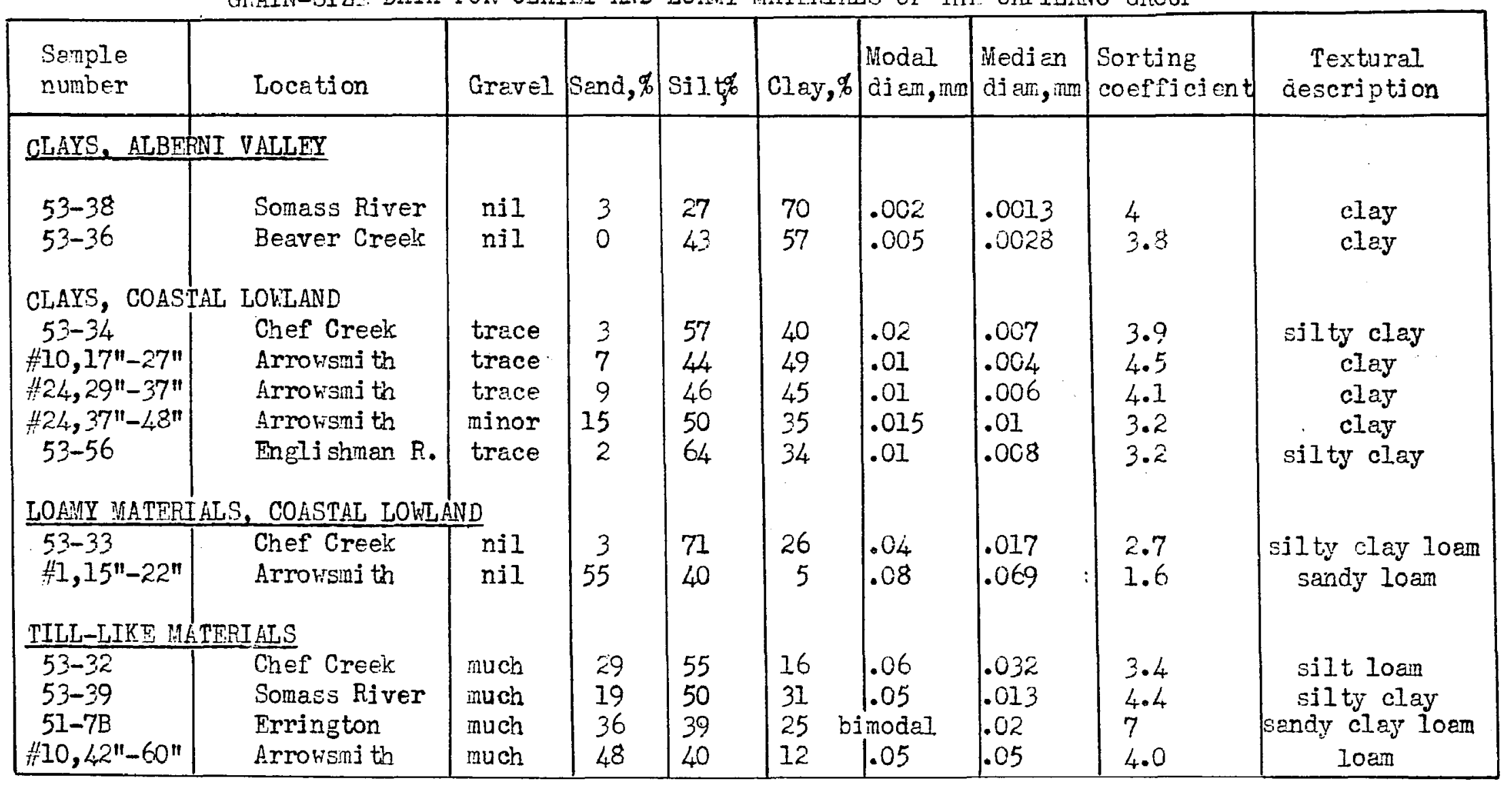

In samples containing appreciable amounts of gravel, the minus $2 \mathrm{~mm}$. fraction only was used in detemining modal and median dicmeters and sorting coeffjcient. 
The marine sands are pale yellow in the soil zone but pale grey to white at depth. They are mostly medium to fine grained and well sorted. Two analyzed samples have median grain sjze of 0.2 mm. and sorting coefficient of 1.2. Al though some of the sands show no apparent stratification, most display prominent bedding parallel or sub-parallel to the horizontel or gently sloping ground surface. The characteristic gentle dips and undulations in the stratification of the marine sands serve as one basis for their distinction from the almost $j$ dentical but strictly horjzontal sands of the Quadra group. Lenses of stratified and Iaminated materiel of a variety of textures lie beneath the clayey marine deposits and separate them from the underlying till. Typically, these lenses are 1 to 3 feet in thickness and consist of pale grey sendy silt and sandy clay wi th laminations a fraction of an inch to an inch in thickness. The materiels generally contain isolated pebbles and larger stones and in places include layers of sand and sandy till-like material. Here and there, a few inches to a few feet of coarse poorly sorted gravel separate the laminated material from the underlying till. None of these materials has yielded marine shells.

The marine and glaciomarine deposits of the coastal lowland typically rest upon till or are separated from the till by the laminated materials described above. In a few places, they rest upon glacjofluvial gravel, upon bedrock, or upon materiels belonging to the Quadra group. In some places the marine succession consists entixely of clayey materials but in others the clays are overlein successively by loamy materials and sand. In depressions, the sandy and/or loamy materials covering the clay characteristically thicken towards the 
depression margins. Marjne deposjts that lie downslope from exposures of sand of the Quadra group consist dominantly of sand al though, as elsewhere, the sand rests upon clay. Marine deposits are especielly thick beneath and around the sbandoned deltas. Generally, the marine beds associated with the deltas consist of clay overlain by loamy materials and sand and do not dfffer materielly in character from the marine beds found elsewhere. Locally, however, the massive marine clay is replaced by lamineted clay, silt, end sand, or by altemate irregular layers of sand, massive clay, and till-ljke material. The surface sandy marine beds borclering the deltas characteristically contain numerous pebbles.

\section{Organic Remains}

Assemblages of maxine shells from the marine and glaciomaxine deposits at about a dozen places in the coastal lowland have been studied by Miss F.I.F. Wagner of the Geological Survey of Canada (Wagner, 1954). Most of the forms in these assemblages are molluscs. Miss Wagner lists between 40 and 50 species none of which is extinct, and reports that the assemblages are similar to those living today in the Gulf of Alaska and in the south part of the Bering Sea (equivalent latitude 60 to 63 degrees). Surprisingly, none of the assembleges has an equivelent latitude south of 60 degrees. Miss Wagner reporta a similar range of equivalent latitude for a much larger number of assemblages from equivalent deposjts in the Lower Fraser Valley. Nei ther on Vancouver Island nor in the Lower Fraser 
does there appear to be any significant differences in equivalent Tatitude with elevation, stratjgraphic position, or nature of material.

The spectes reported by Miss Wagner from the marine and glaciomarine accumulations of the coastal part of the map-area live in the epineritic and intertidal zones. The few species that live exclusively in a littoral environment were found in sandy and loamy materjals and are not represented in the clayey materjals.

\section{Mode of Origin}

Most of the materiel comprisjng the marine deposits was brought into the sea by wave action along the sea shore, al though a substantial quantity of materiel was carried into the sea by streams. This conclusion is based upon the thickenjng and thinning of the deposits in relation to the hills and hollows of the groundmoraine surface and to successive positions of the stream mouths as marked by the abandoned deltas. In addition, some of the coarse materfal in the clayey deposits is beljeved to have been dropped by floating glacial ice.

The clays and silty clays may well have been transported in suspension well out fram shore to be deposited as off-shore bottom muds, but the sands must largely have accumulated close to shore. Localization of the exclusively littoral molluscan species in the sands supports this inference. On the other hand, the sands are not surfaced by ridges or other beach forms but rather are of uniform 
thickness and of broad extent. Probably they accumulated on gently sloping sea bottoms in the lower part of the intertidal zone for a short distance below the low tide line. The clayey and loamy materials probably accumulated, in the main, below the low tide line. It should be noted that the bottom deposits must all have passed through the shore zone during retreat of the sea. to its present posjtion, and that their surface must therefore have undergone some reworking by waves.

Many of the clays and silty clays are not "normal" marine deposits in that they contain isolated stones and appreciable quantities of sand. Some of the stones are as much as several feet in diameter. As discussed in connection with similar deposjts of the Dashwood group, such mixtures of coarse materials with fine sediments may form adjacent to the shoreline by wave and current mixing or may accumulate in deeper water ej ther by submarine downslope "mass" movements or by dropping of rafted gravelly material into sea-bottom muds. The till-like clayey materials and some of the most stony clays may possibly have originated by any or all of these processes. On the other hand, the small percentage of sand and the isolated stones in thick uniform clays apparently cannot be attributed to the two first-mentioned processes and must be rafted materjal. In view of the quantity of material and the size of the stones involved, the rafting agent must have been ice rather than floating logs or other debris. As suggested in the paragraph dealing wi th these deposits 
in the discussion of the Vashon group, some if not much of the rafting ice is inferred to have been glacial in origin. On this basis, some of the stony clayey materials are considered to be glaciomarine. A more extensive account of the possible modes of orjgin of the stony cleys and related materiels has been provided by J.F. Hrmstrong and W.L. Brown (1954).

The lenses of poorly sorted clay, silt, sand, and gravel that lie beneath the marine clay have yielded no marine shells and differ from the marine deposits in being finely laminated. They are probably of fresh-water origin. They could readily be dismissed as having formed in ice-marginal ponds during deglaciation were it not that the sea appears to have advanced in to the Georgia depression against the front of the retreating glacial ice. A possible explan-ation is that these materials were deposited in a narrovi zone of fresh water beneath the glaciel ice and in the base of crevasses, as the $i c e$ began to lift off the ground through the buoyant effect of the encroaching sea water. Fresh water in and beneath a tidal glacier terminus would float on the salt water, as in the case of ground water in permeable materials along a sea shore. Nonetheless, fresh water would probably extend far enough in to the basal openings along the inner edge of a floating ice tongue to permit deposition of a narrow belt of fresh-water sediments as suggested above at times when the supply of fresh water was large owing to rapid glacial melting. 


\section{Marine Veneer}

On the slopes and hills of the coastal lowland, the marine accumulations are replaced by a veneer (generally less than 5 feet thick) of extremely variable, but dominantly gravelly materials. In its most characteristic form, this veneer consists of $I_{2}$ to 3 feet of coarse bouldery gravel but it also includes pebbly and sandy gravel as well lenses of sand, loamy materials, clay, and till-like materials like the materials comprising the thicker marine deposits. Although leaching has characteristically removed any calcareous shell material that may have been present originally in the veneer, casts of marine shells are preserved in many of the loamy and till-like materials and in a very few cemented gravels.

\section{Nature of Materials}

Typical examples of the coarse gravelly phase of the veneer are illustrated in Figures 53 and 54. These gravels are rather poorly sorted and consist of boulders, cobbles, and pebbles set in a matrix of sand. Screen analyses of the mims $64 \mathrm{rm}$. fraction of three typical samples revealed that they consist of pebbles and sand in about equal proportions and contain less than 5 per cent of silt and clay; an exceptionally stony sample contains 80 per cent of pebbles and less than 3 per cent of silt and clay. The sorting coefficient of each of the three typical samples is about 5. Stratification is absent or extremely indistinct although cobbles and large pebbles in some of these gravels are rudely shingled and the large stones in a few are concentrated in the base of the gravel 


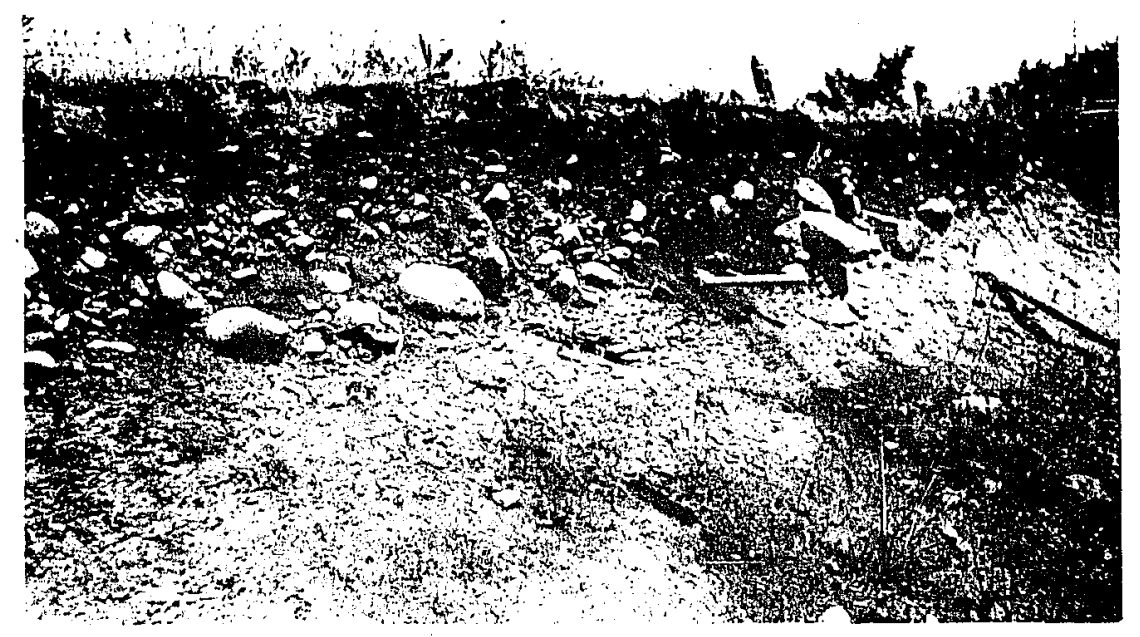

Figure 53. Typical coarse gruvelly phase of the marine veneer underlain by till. The gravel is interpreted as a lag concentrate formed by wave washing of the till. Exposure in a road cut near Comox.

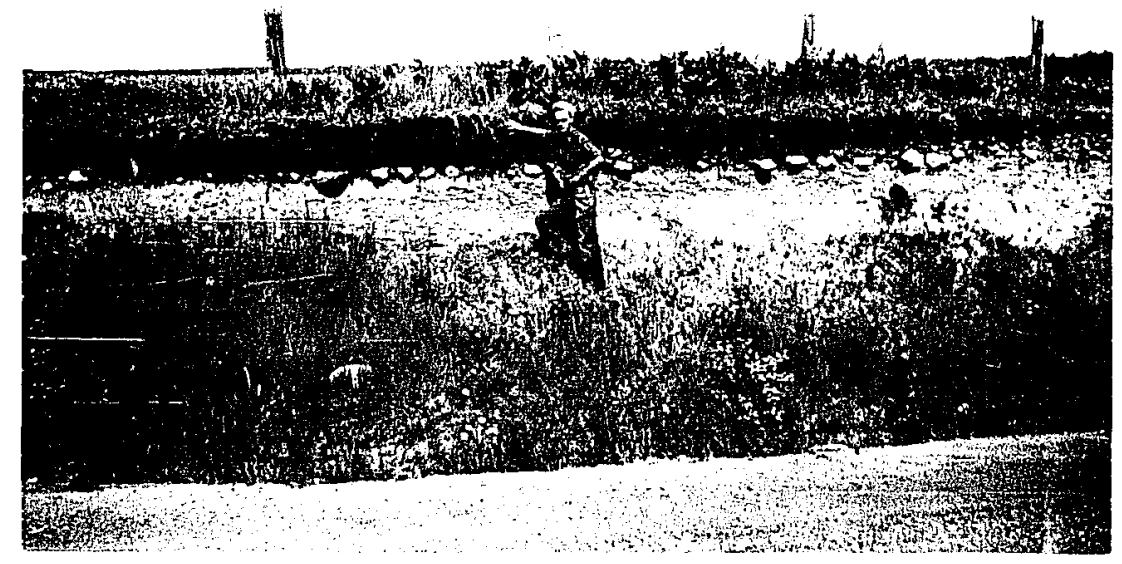

Fi gure 54. Gravelly marine veneer in which largest stones rest on the underlying till. Same locali ty a.s Fjgure 53. 
veneer (see Figure 54). The stones in these gravels are typically subangular to subrounded and are similar in size, shape, and Ii thology to those in the underlying or nearby till of the Vashon group. Surfaces of some of the stones are striated. These gravels appear to be a lag concentrate of stones and sand from the former uppermost parts of the till. The widespread presence of "pebbles" of till in the gravel lends support to this conclusion.

In some places the veneer consists of coarse, unstratified gravel like that described above but containing more silt and clay; this material is intermediate in texture between the gravels just described and disaggregated till. Elsewhere, the veneer includes pebble gravels and pebbly sands that are much better sorted than the coarse gravels and that display well-developed stratjfication. The individual beds generally are parallel to the contacts of the gravel veneer (and the ground surface) but some form a cross-lamination dipping upslope or downslope.

Sand, loamy materials, clay, and till-ljke materjels are all locally represented in the veneer. They are li thologically similar to the thicker, more continuous marine accumulations described in the preceding section of this report. Till-like materials are more abunaant and more varied than in the thicker marine accumulations. Some of them rest upon till and are like till that has been slightly enriched in clay and silt. Such materjals characteristically constitute a marginal phase of stony clay or replace the clay in very small or shallow depressions. Other 
till-like materials are more silty (sample 53-32, Table: III) and typically are separated from the till by a few Inches of clay (see Figure 55). Commonly, they are covered, in turn, by the stratjfied variety of gravel. Upon superficial examination, they could be classified as till and would seem to record a glacial Invasion following marine submergence, but careful search reveaj.s that most of them contein casts of marine shells. They appear to be a thin stony phase of the silty and loumy marine deposits.

\section{Mode of Occurrence}

The varied materials comprising the veneer exhibit a consistent textural axrangement in relation to the hills and hollows of the ground surface. In most generel terms, the slopes and convex hill tops are covered by a veneer of gravel, whereas flatter areas and hollows are surfaced by clayey, loany, or sandy materials. The idealjzed cross-section comprising Figure 57 11lustrates the typical arrangenent of the components of the veneer on a slope and their transition into the thicker marine deposits in an adjoining depression. The gravel on such a slope is well washed (j.e. contains very little silt and clay), and the sands, loamy materials, clay, and till-like materials form clear-cut lenses. Both coarse unstratified lag gravel and pebbly stratified gravel are typically represented. This distribution of deposits (Figure 57) obtains where hills and hollows are at least several hundred feet across and have relief of severel tens of feet and where the slope 


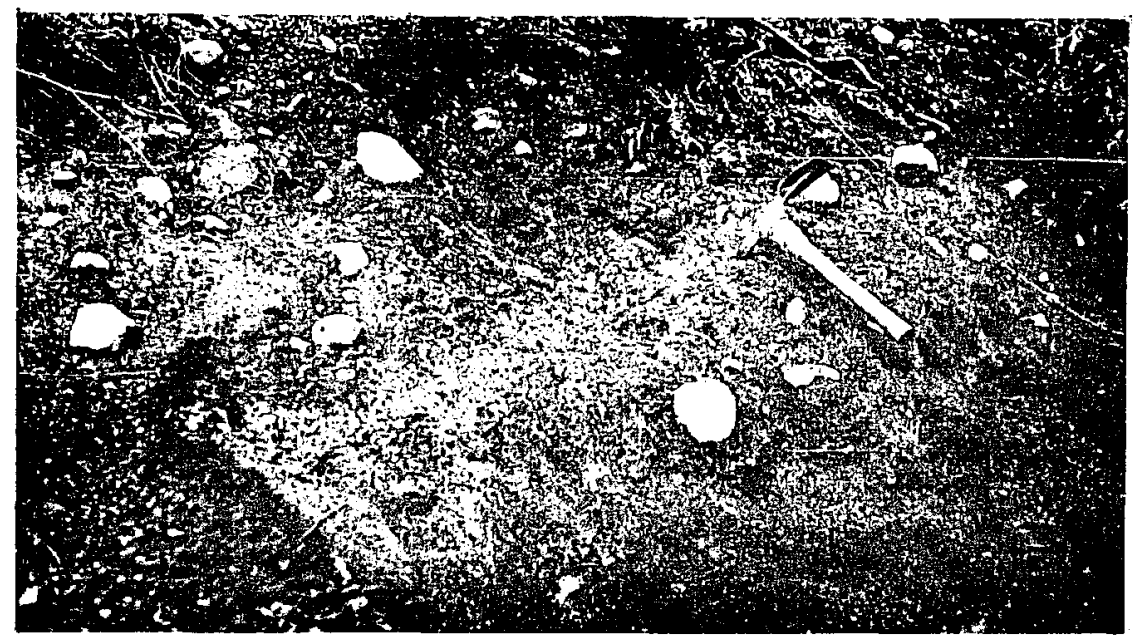

Figure 55. Marine veneer showing thin layer of clay (light colour, extending from pick to lower left) underlain by till and overlain by silty, till-lfke material containing casts of marine shells. Coarse gravel 2 feet thick overljes the tjlllike material above the top of the photograph.

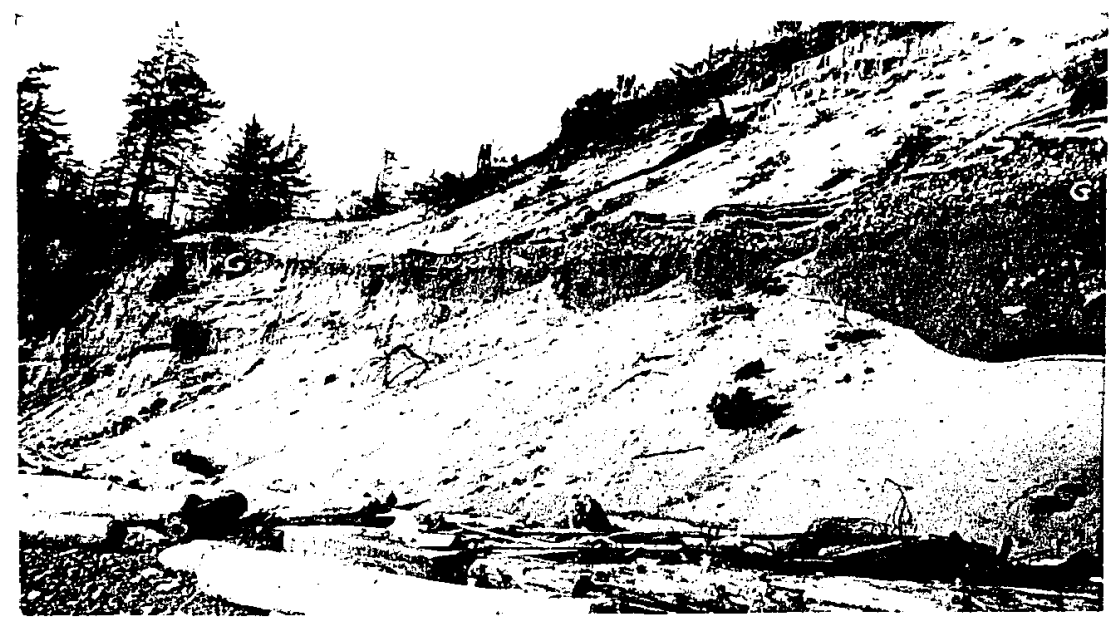

Fjgure 56. Marine lag gravel (G-G') resting on Vashon till (right to centre) and on quadra sand (centre to $l \in f t$ ). The gravel is about 3 feet thick. The sand above the gravel in the right part of the photograph is part of a dune. The exposure is on the comox sea cliff. 


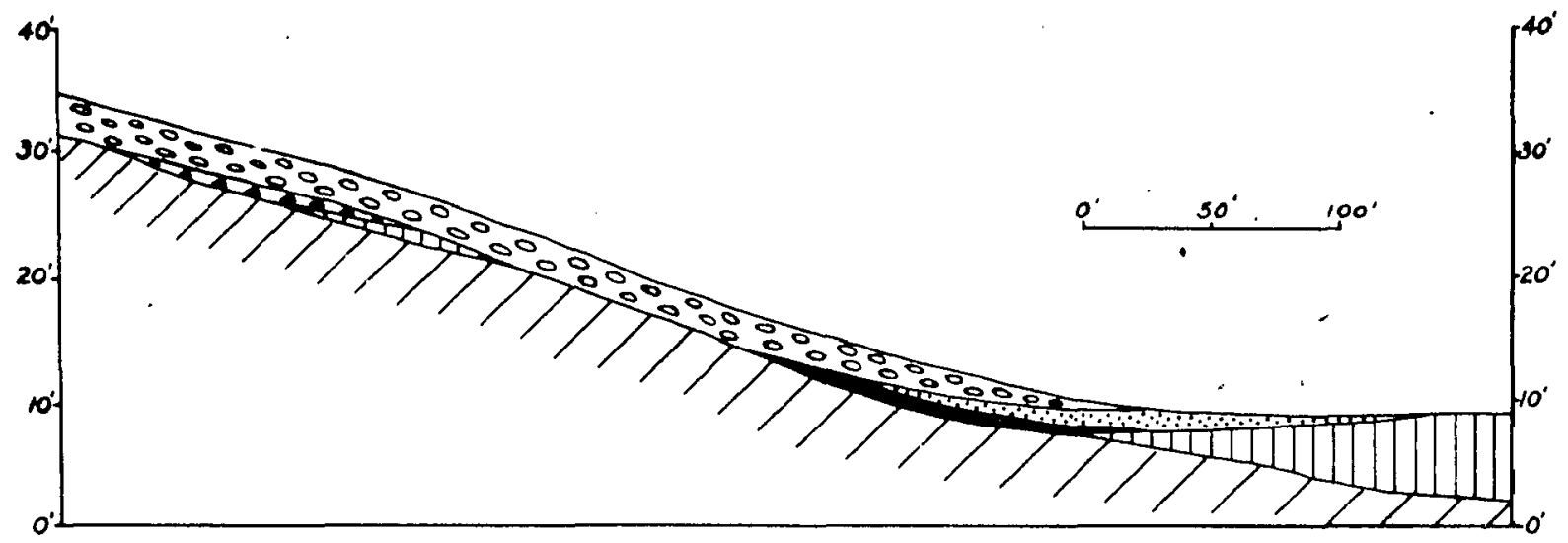

$\because$ Gravel.

in Sand.

|| ||Clay.
- Loamy materials.

... Till-like materials.

/ T111.

Figure 57. Diagramatio oross-seotion illustrating the typioal arrangement of components of the marine veneer on a slope and their rolation to thicker marine doposits in a depression. 
of the steeper parts of the hillsides exceeds 5 per cent. Simjlar, al though lesí pronounced changes of texture with topography are found where the topographic features are smaller and the slopes gentler; they can be detected even where local relief is less than 10 feet and individual hills and hollows are only a few tens of feet across. In such places, depressions and flat areas are floored by till-like materials intermedicte in composition between the underlying till and marine clay, whereas slopes and hills are veneered by 2 loose gravelly deposit only slightly less silty and clayey and slightly more stony than the till.

In the above discussion, the marine veneer has been represented as resting upon the ground moraine of the Vashon group. It also forms a patchy cover on the bedrock outcrops of the lowlends, rests upon sand and other deposits of the Quadra group where the Vashon till is absent (see Figure 56), and surfaces small bodies of ice-contact gravel. In these situations the veneer consists mainly of gravel and sand al though it locally includes lenses of clay and loamy material. Recognition of the gravelly veneer on gravelly icecontact deposits is possible only where such lenses of clay and loamy material are found.

Here and there, shoreline forms can be traced on the surface of the veneer deposits. These features are not portrayed on the accompanying geological map (Plate I) because they cannot be traced in the forest and because of their lack of continuj ty in the few places where it has been possible to trace them. Only rarely 
can they be identified on the aerial photographs. However, it seems likely that if the forest were removed, the whole area occupied by the voneer would be seen to display such shoreline features.

Bars and spits have been identified in a number of places. Typically, they take the form of elongated ridges of pebble gravel 5 to 15 feet high and a few tens of feet wide that connect at one or both ends onto higher ground. The crosssection sketched in Figure 58 includes a pebbly gravel bar bordered on the south by clayey, loamy, and till-like materials that appear to have accumulated in a lagoon enclosed by the bar. Broad, indistinct spits occur on the south and southwest sides of some of the low hills of the coastal lowland. These take the form of low ridges of pebble gravel and sand a few hundred feet wide and 1000 to 2000 feet long.

$$
\text { Narrow, rather indistinct shoreline terraces extend }
$$
along some of the sloping hillsides. Typically, each terrace comprises a narrow flat surface a few tens of feet wide eroded into the till slope and bears a veneer of marine clayey and loamy materials that are partly covered by sand and sandy gravel. The downslope edge of each terrace and the slopes between the terraces are surfaced by a coarse veneer like that on the hillslope illustrated in Figure 57. The lowest of a series of terraces of this type appears at the left side of Figure 58 . More prominent 


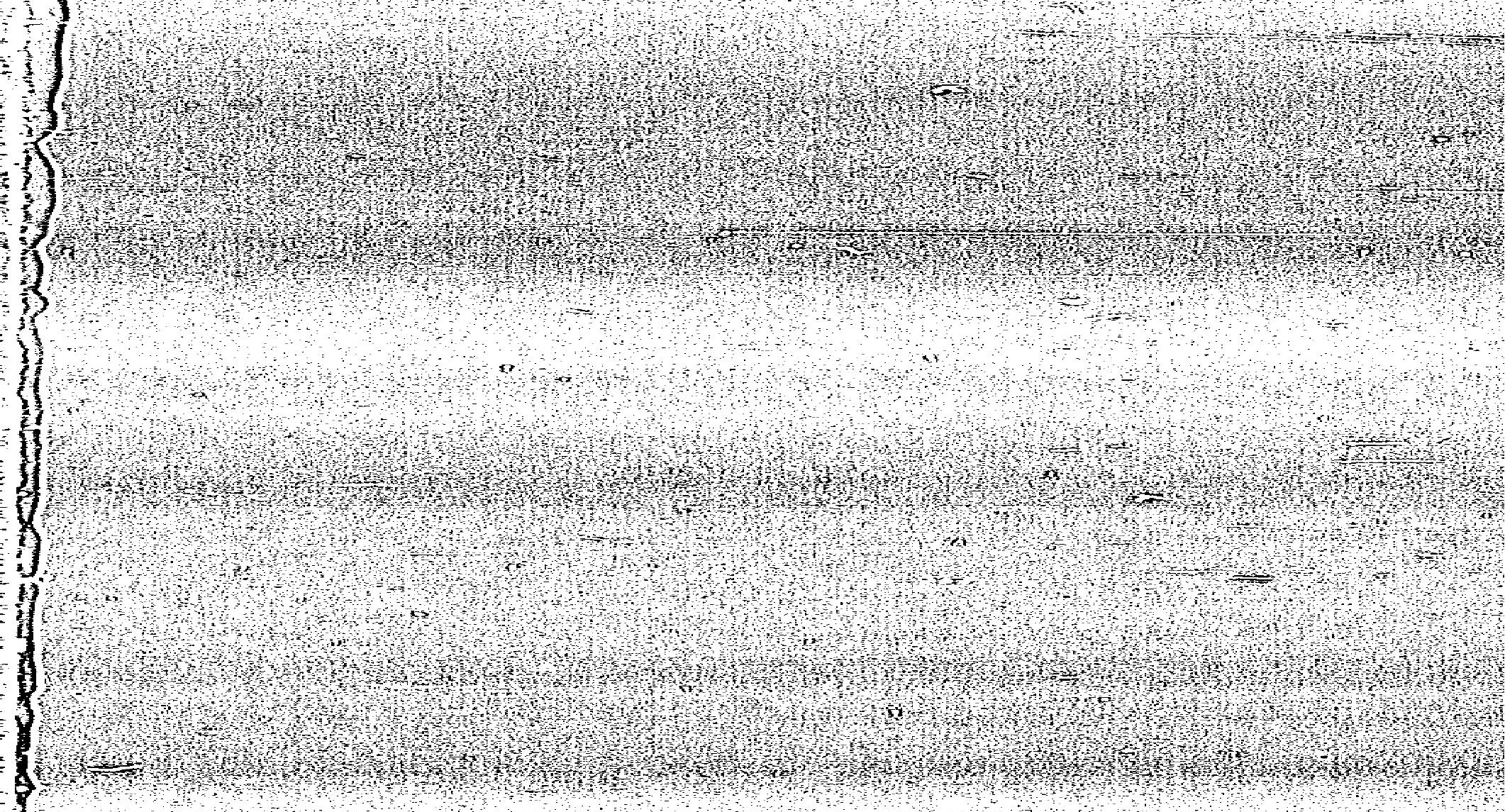




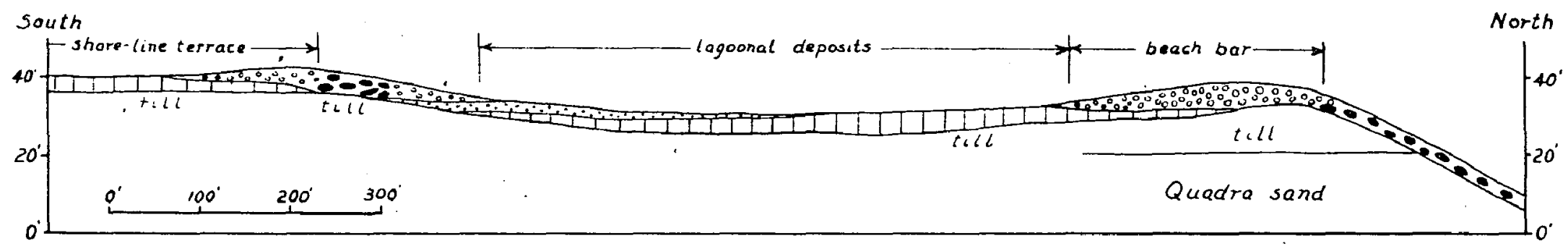

I: Bouldery lag gravel.

@o Pobble gravel. $\quad|||| \mid C l a y$, till-like materials.

Figure 58. Details of the marine reneer at Qualicum Beach along a line extending south from the high school. Ground profile from hand-level survey. Geology from test pits and ditches, and is partly diagranmatic. 
terraces are found where the Vashon till sheet is discontinuous or absent and the easily eroded Quadra sand has been exposed to wave attack. Some such terraces include a distinct constructional outer part, consisting of sand, and an erosional innor part consisting of a thin bouldery, sandy mantle lying on the eroded surface of the Quadra sand. Other terraces cut into Quadra sand are not bordered by a constructional sand terrace but rather by a broad accumulation of marine sand.

Mode of origin

The veneer deposits of the coastal lowland described above are inferred to have originated along and adjacent to successive marine shorelines and to be complementary to the marine accumulations discussed in the last section of this report. Some of the clayey phases of the veneer are probably offshore marine deposits that have been surrounded and partly covered by shore deposits.

Some of the components of the veneer contain casts of marine shells and some display shoreline structures, Others are identical to the materials comprising the marine accumulations or grade laterally into such marine accumulations. These components of the veneer are confidently classified as marine materials that, for the most part, formed in the shore zone. On the other hand, the coarse unstratified gravels that make up a large part of the 
veneer are lithologically similar to fluvial. gravels and to superglacial till (compare Figure 53 with Flint, 1949, Figure 28) as well as to shoreline lag gravels. The localization of these gravels on the crests and slopes of hills, however, cannot be accounted for in terms of either fluvial or glacial deposition. This distribution pattern can have resulted only from formation of the gravels as a lag concentrate of stones from the underlying and nearby materials by wave action along exposed parts of successive shorelines. The till-like materials of the veneer differ but little from the tills of the Vashon group. Their classification as marine deposits is based upon the presence of casts of marine shells, although where shell casts are not found, slight differences in texture and consistency provide an arbitrary basis for distinction of marine and glacial materials.

\section{Denman Island Marine Deposits}

A thick succession of sandy marine depcsits belonging to the Capilano group is exposed along the northern part of Komas Bluff on Denman Island, about 6 miles north of the northern edge of the map-area. These deposits are described in some detail here because they provide evidence of a rise in sea-level.

As illustrated in Figure 59, the Capilano group sands in this locality rest upon Vashon, Quadra, and Dashwood group deposits. The thick Capilano sands in the northern part of the sea cliff are readily mistaken for Quadra group sands. However, the Quadra sands 


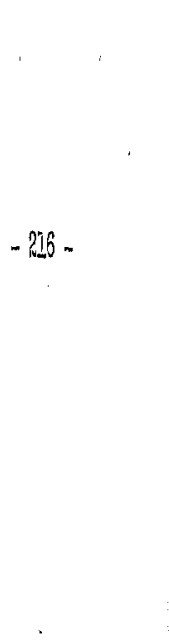

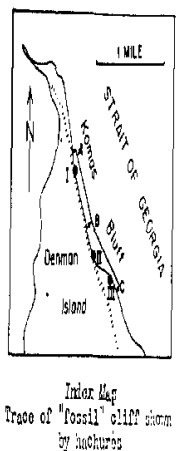

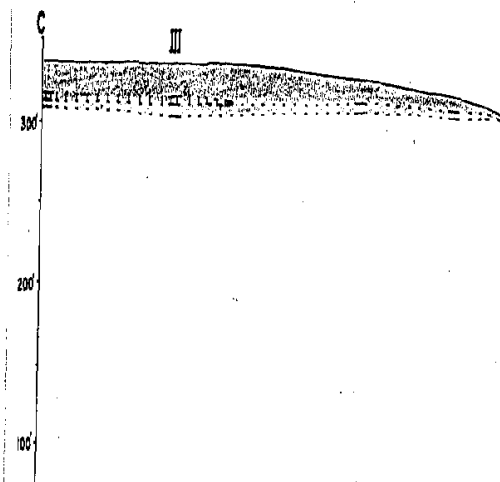

incentes

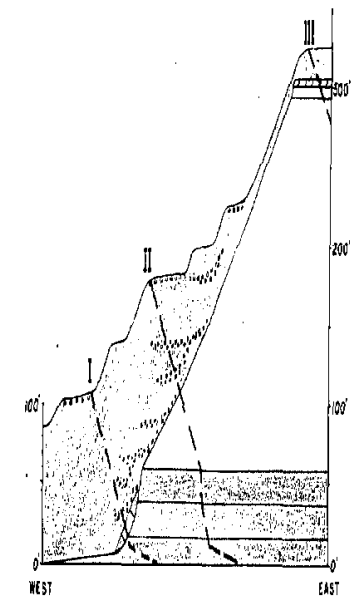

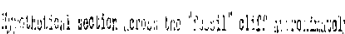

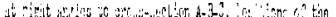

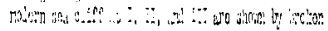

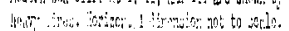

1562

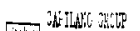

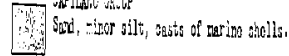

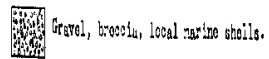

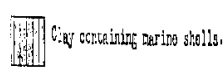

Ti:1.

Tod hiof

Sud

Asilt, grapal, tard, paly bolk, driftrod.

Jor300 GRCF

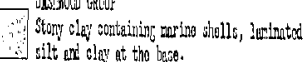

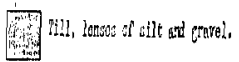

ara

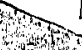

B 
Iie conformably on the subjacent deposits, whereas the Capilano sands are separated from the underlying materials by a discordant contact that strikes almost parallel to the present sea cliff and that dips steeply into the cliff face. The trace of this contact is visible in Figure 22. In one place, a block of the DashwoodQuadra sediments adjoining this contact has besn downfaulted about 3 feet relative to the undisturbed strata east of the contact. Tho Capilano group materials above and west of the contact are medium-grained sands containing thin silty and clayey beds, lenses of gravel, and lenses of breccia. Gravel lenses are particularly abundant along the contact. Clay is found along the contact where the underlying material is till. Stratification within the Capilano materials is more or less horizontal except within a few feet of the contact, where the beds dip gently to steeply westward and strike parallel or sub-parallel to the contact face (see Figures 59, 60,61).

The breccias mentioned above (see Figures 60, 62) consist of more or less angular blocks of coherent, finely stratified sand up to 2 feet across and of stones up to 1 foot across set in a matrix of loose sand. One breccia lens at II (Figure 59) also contains chunks of till and of clay with casts of marine shells. The coherent sand that occurs as blocks in these breccias has been found in place only in the uppermost part of the Quadra group sand along the highest part of the exposure near III (Figure 59). The chunks of till and of marine clay in the breccia at II (Figure 59) alinost certainly have been derived from the Vashon 


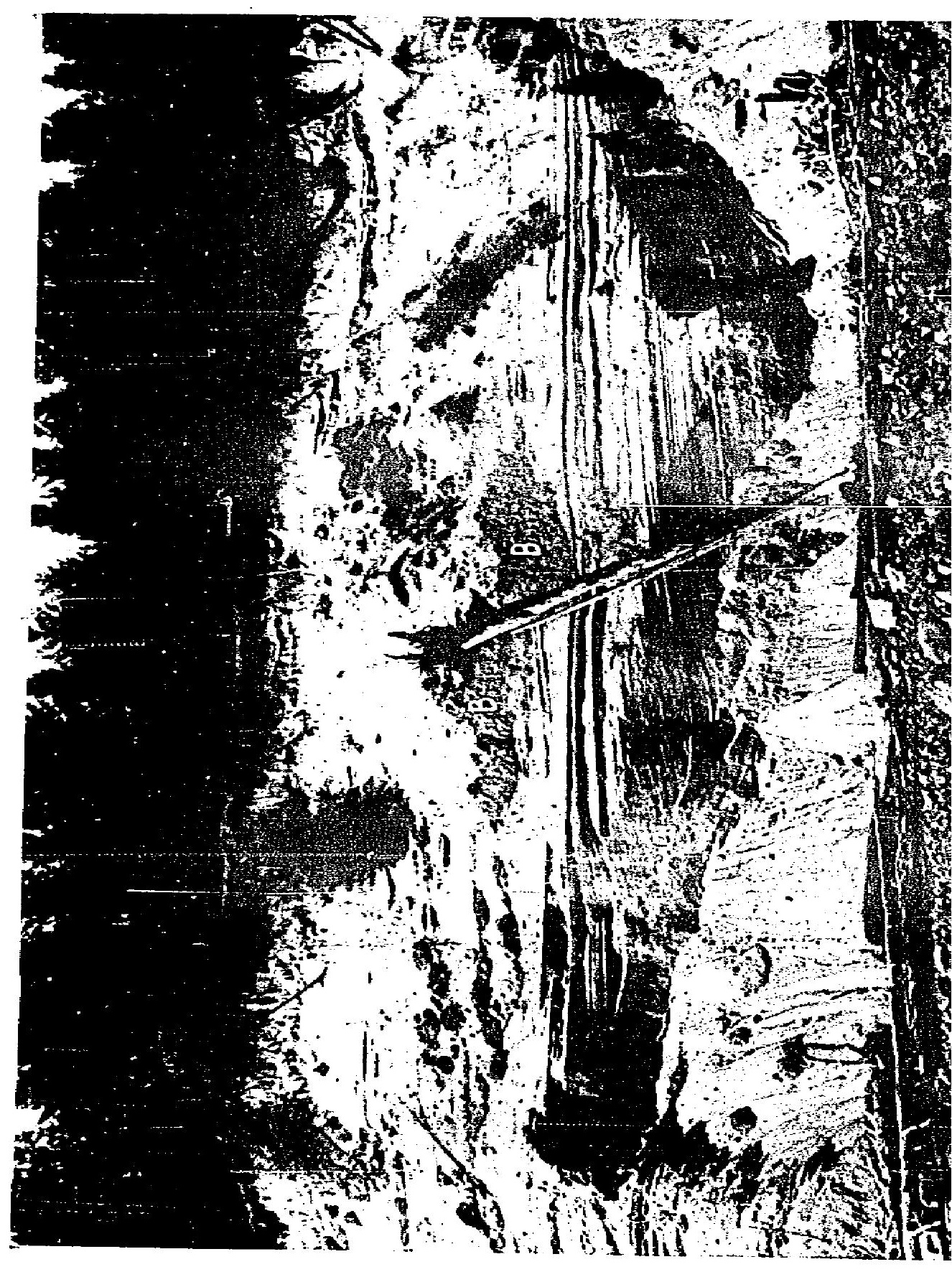




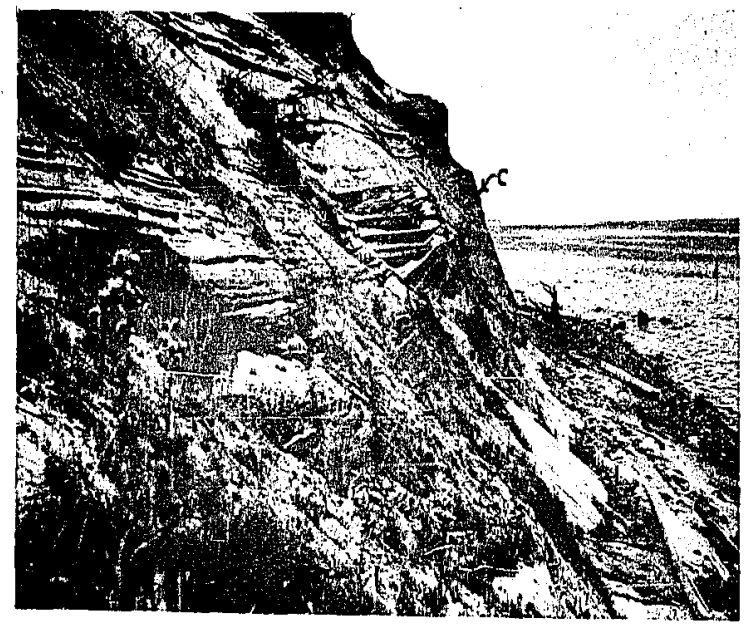

Figure 61. View northeast along Komas Bluff, Derman Tsland, showing horizontal and inclined marine sands of the Capilano group. The basal marine sand beds, imnediately above the trace of the "fossi]" cliff $\mathrm{C}-\mathrm{C}-\mathrm{C}$, dip into the face parallel to the "fossill" cliff. The cut bank is 90 feet high.

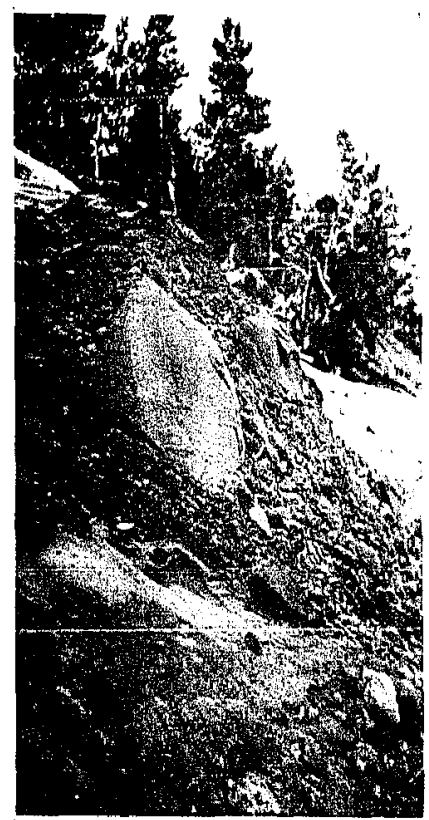

Figure 62. Breccia lying within marine sands at II, Figure 5\%. The breccia consists of blocks of coherent Quadra sand (large blocks), pieces of till and marine clay, stones, and marine she11s. The largest blook is about 2 feet across. 
till and overlying clay that lie immediately above the coherent sands of the Quadra group.

Marine shells occur in the clayey beds at the base of the Capilano deposits in the northern part of the exposure, and casts of shells have been found in silty beds throughout the sand succession. The brecci: 1llustrated in Figure 62 (at II, Figure 59) contains a multitude of marine shelly. A collection of these studied by Miss F.J.E. Wagner of the Geological Survey of Canada includes 23 species (Wagner, 1954). The depth ranges of $2 I$ of these species, as recorded by Miss Wagner, indicate that 5 species are exclusively intertidal, that II others are found in the intertidal range as well as in deeper water, and that the upper limit of the depth range of the remaining 5 species is less than 20 fathoms below mean sea-level.

In view of the relationships outlined above and illustrated in the cross-section, these Capilano group materials are interpreted as marine deposits that accumulated against a steep face cut into Vashon, Quadra, and Dashwood deposits. This face apparently formed a sea cliff along the west side of Denman Island when the east coast of the island (and the east-facing sea cliff) was well to the east of its present position. The breccias within the marine sands contain blocks of materials that would have been exposed near the top of the sea cliff and are interpreted as talus deposits that accumulated along the shore at the 
base of the cliff. If this interpretation is correct, the occurrence of these breccias from 20 to 120 feet above the present sea-level indicates that their deposition accompanied a sea-level rise of at least 100 feet. The horizontal attitude of the stratification of the thick succession of marine sands lends support to the inference that these deposits accumulated by upward building during an interval of sea-level rise rather than by outward building of a wave-built torrace into deep water. Consequently, the sequence of events recorded by these deposits seems to have been as follows:

(1) Initially sea-level stood more than 300 feet above its present position and marine clay and sand were deposited on the Vashon till at III. (2) The west facing "fossil" cliff was cut-probably by marine shore processes during an interval of falling sea-level. The presence of marine shore sands and breccias abutting against the cliff just above the modern beach at $I$ indicates that sea-level dropped to at least its present position. (3) Next, the thick sands and accompanying breccias accumulated along successive positions of the sea shore below the cliff while the sea-level rose to at least 150 feet above its present position. (5) Since deposition of these Capilano materials, sea-level dropped to its present stand but details of this change are not . known. 
Distinction of these sandy marine deposits of Denman Island from sands of the Quadra group and the above interpretation of their significance has been possible because of the extensive and very excellent exposures; less-well displayed occurrences of the same type probably would remain unrecognized. Anomalous sandy deposits associated with Quadra sands at several places in the coastal part of the map-area probably belong in this category.

\section{Abandoned Deltas and Fluvi \&l Terrace Deposits}

Successions of small, steep-fronted abandoned deltas border the gullys and valleys of the modern streans of the coastal lowland. They are simjlar in form and material to the moderm deltas that occur where these streams enter the Strait of lieorgia. A few of the highest deltas bear jce-contact features, as outlined in the discussion of the Vashon group. All the deltas are closely associated with the marine deposits and appear to have accumulated in marine water. Discontinuous fluvial terraces and rare gravelly stream deposits along the walls of. the modern stream valleys as well as a few abandoned stream channels branching from these valleys mark the courses of the streams that bujlt the deltas.

The deltas are a few hundred feet to a mile across and are extremely varjable in outline (see geological map, rlute 1) The top surfaces of the deltas are horjzontal or slope very gently 
seaward. Most deltas are bordered on their seaward edge by a clearly defined scarp a few feet to 100 feet high and sloping away from the delta at 5 to 20 degrees. In a typical delta, part of this face is constructional and parallels the fore-set bedding wi thin the delta wile part has been undercut by lateral swinging of the stream while building the next lower delta. The constructjonal face locally is notched by small wave-cut terrace steps. Some deltas built upon relatively flat ground are bordered by recognizable spjts and bars. Thin delta deposits along some of the streams are not bordered by a break in slope or by any distingujshing constructional features. Mapping of the contact between such deltaic deposits and adjoining marine sands and sandy gravels is purely arbitrary.

All but the thinnest deltaic deposjts display an internal "delta structure" (see Figure 63). The top-set beds are $I$ to 8 feet in thickness and typjcally consist of pebblecobble gravel that almost universally is coarser than that forming the underlying fore-set beds. The top-set beds generally show prominent horizontal stratjfjcatjon but are locally massive and identical in appearance to the coarse gravelly phase of the marine veneer. Almost everywhere, the top-set gravels truncate the underlyjng foremset beds although, in a few places, individual top-set strata are traceable downward into the fore-set beds. The fore-set beds dip at 10 to 25 degrees and range up to 50 feet or more in thickness. Typicelly, they consist of pebble 


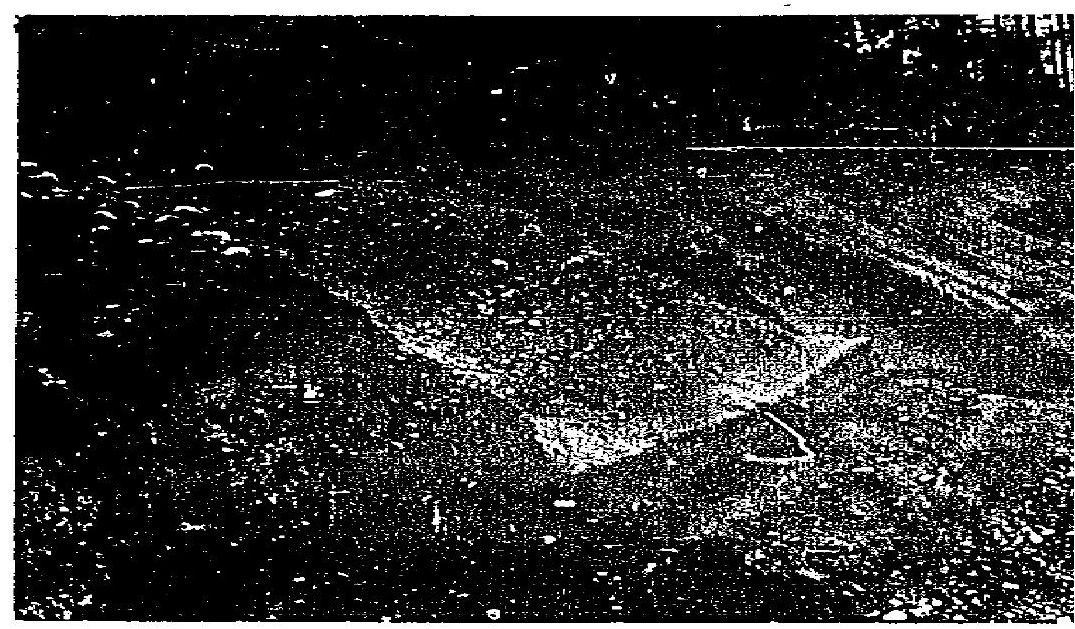

Figure 63. Delta gravels, east sia the powex line. Top-set beds ó $r e$ set beds 35 feet thick.

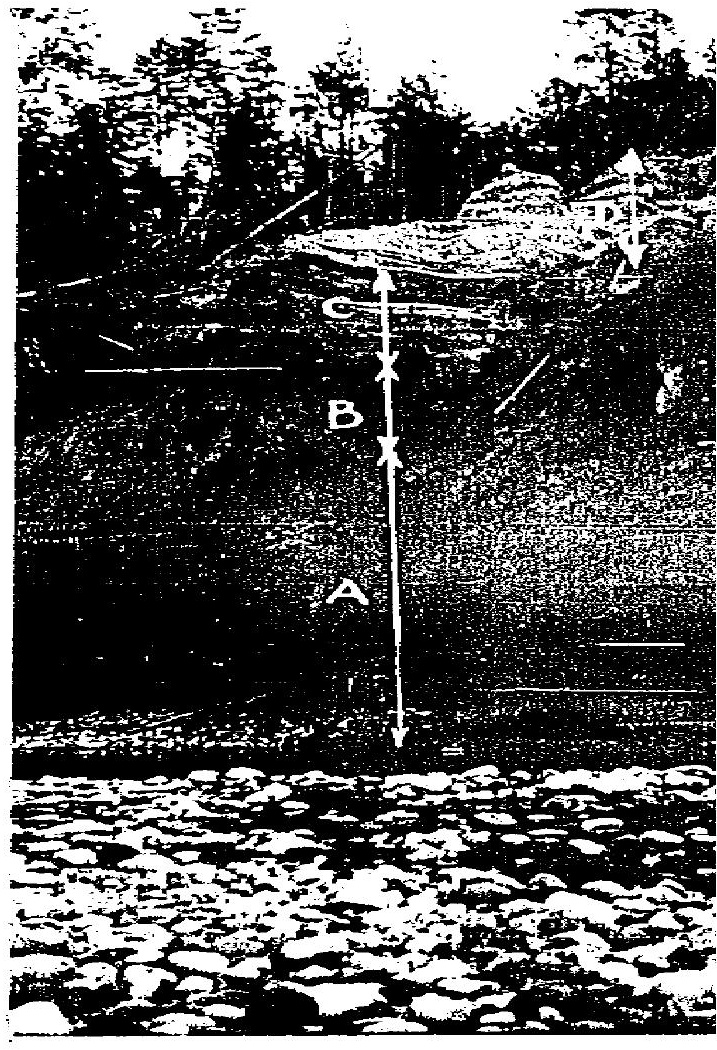

Figure 64. Same exposure as F'igure valley floor. A, till; B, marine sands; D, fore-set and top-set del. of the face is 100 feet. 
gravel and pebbly sand al though in a few deltas they are dominantly sand and in a few others they include numerous cobbly beds. Locally, sandy or silty strata within the fore-set secuence contain casts of leaves, twigs, or marine shells. The fore-set beds rest upon a varjety of matericls. Commonly a few feet to 20 feet of sand dipplng gently seaward separate the fore-set gravels from underlyjng marine clay (see Figure 64). Marine shells are sparsely distributed through this sand. In some places, this sandy bottomset layer is absent and the fore-set beds rest directly on marine clays, sandy clays, and till-like materials or are seperated from these materi 1 ls by a few inches of silt. Rarely, the botton-set sands are replaced by up to several tens of feet of horl zontally laminated sand, silt, and clay. Almost all the deltas whose Internal structure is exposed consjst of a single serjes of topset and fore-set beds and would seem to have been built at one stand of the sea. However, faces cut Into a very few deltas expose several alternations of hori zontal and inclined strata; these appear to have resulted from superposition of several individuel delta structures during an interval of rising water level.

The stream terraces and abandoned channels extending upstream from the abandoned deltas are mostly erosional features, veneered by thin, stony lag gravel which rests upon older unconsolidated deposits. Such thin veneers are not show on the geological map. A very few terraces, principally along Englishman 
River and Nanoose Creek, are underlain by deposits of gravel and sand up to 20 feet in thickness. Exposures showing the internal structure of these deposits have not been found, and it is not known which are fluvial floodplain deposjts and which also include deltaic materiels.

\section{Extent of Marine Submergence in the Coastal Lowland}

As can be seen from the geological map (Plate I), the highest marine features of the coastal lowland are betreen 450 feet and 500 feet above the present sea-level. Marine-type clays and sands are found abundantly up to an elevation of about 450 feet and marine shells are common up to an elevation of 400 feet. An isolated occurrence of stony clay containing marine pelecypod shells has been found in a gully a mile east of Chef Creek just north of the forestry road at an elvation of 465 feet 6 .

On some hillsides underlain by till and displaying a moderately uniform slope, it has been possible to locate (wi thin a vertical range of 10 or 20 feet) the boundary between "washed" Eravelly phases of the marine veneer on the lower part of the slope and "unwashed", disaggregated till contajning a substantially larger proportion of silt- and clay-size material higher on the slope. As shown on Table IV, this upper limit of wave washing is about 470 feet above the present sea-level.

The marine deltas bordering the various streams of the lowland provide an Independent measure of the extent of the marine

6 feet.

Elevation by Paulin Altimeter and may be in error by 20 
TABLE IV

LIMIT OF WAVE WASHING ON HILLSIDES, COASTAL LOWLAND

Location

Hill 2 miles east of Errington, north side

Hill 2 miles east of Errington, south side

Base of mountain slope southwest of Errington

Base of mountain slope south of Coombs

Base of mountain slope, Kinkade Creels

East branch of Waterloo Creek
Elevation in feet

480
470
450 (approx.)
470
470
480

\section{TABLE V}

ELEVATIONS OF HIGHEST DELTAS, COASTAL IOWLAND

Location

South Englishman River, east side

Rosewall Creek, west side

Waterloo Creek, west side

Wilfred Creek, west side
Elevation in feet

465

470

475

485

Elevations in Tables IV and V determined by Paulin Altimeter. 
inundation. The highest delta terraces along South Englishman River, Hunts Creek, Nile Creek, Thames Creek, Rosewall Creek, Wa.terloo Creek, Wilfred Creek, and Cougarsmith Creek are between 450 and 500 feet above the present sea-level. The elevations of four of these highest deltas, as determined by Paulin Altimeter are listed in Table $V$.

\section{DEPOSITS ON THE FLOOR OF ALBERNI VALLEY}

In Albermi Valley, as on the coastal lowland, marine deposits together wi th associated deltajc and fluvial terrace deposits bear record of an interval during which the sea stood higher than at present. Here the marine deposits extend only 300 feet above the present sea-level. As would be expected in a narrow landlocked inlet of this sort, the marine deposits are indicative of an abundant supply of mud and a general veakness of wave action. Hills and slopes bear a loose, stony, loamy veneer differing little in texture from the underlying till. Depressions, both large and small, contain accumulations of clay. Well-washed gravelly marine-shore deposits like those of the coastal lowland are of very limited extent in Alberni Valley. A few abandoned deltas are found along some of the small streams, and, as discussed in connection with the Vashon group, some of the terraced icecontact deposits appear to be deltaic and marine. Terraced fluvial gravels and sands border Stamp, Sproat, and Somass Rivers. They contain lenses of marjne clay and stony clay and may be estuarine in origin. 
Albernj Clay

Clay and stony clay cover much of the floor of Albernj

Valley. In addition to occupying the extensive areas show as such on the geological map (Plate I), clay forms numerous thin patches wi thin the areas shown as marine veneer. A veneer of sand mantles the clay in a few areas adjacent to jce-contact deposjts. In most places, the clay rests upon till, but not uncommonly it overlaps on to bedrock, and locally it lies directly upon ice-contact gravels. Beneath the river terraces, lenses of clay are intercalated with gravel and sand. Locally, the clays attain a thickness of more than 30 feet.

The clayey marine deposits of Alberni Valley are similar in appearance and constitution to those of the coastal low1and. The description of the latter on an earljer page will serve for the Albernj clays except that the Alberni materials are more clayey, less sandy, and less stony than those of the coastal lowIand. The difference in clay content is illustrated by the tabular list of mechanjcal analyses (Table III). Most of the Albernj cleys are massive or indjstinctly stratjfjed but a few display prominent fine lamination. Clays adjacent to the Great Central ice-contact deposits and in a few other places contain thin laminae of sand and silt and in part are overlain by a few feet of sand.

Casts of marine shells have been found in the Alberni clays in many places and the shells themselves were seen in a few 
places. Nonetheless, extensive areas of clay classified as marine on the accompanying geological map have so far yjelded no organic remajns. Casts of marine shells are especially abundant in the clay lenses in the river terrace deposits along Somass River where they are associated wi th rare jmprints of leaves. They will be discussed below in connection with the terrace deposits.

The Albern! clays would seem to consist majnly of muds that were washed into the ancestral Albernj Inlet by streams, al though some of the clayey material probably was washed out of clayey tills by wave action along successive sea shores. The clays are interpreted as sea-bottom muds that accumulated offshore, adjacent to the shore, and even on tidal flats. The stones in some of the clays appear to reflect a tide-flat environment and other stony clays adjacent to deltas are ascribed to submarine slope movements. As on the coastal lowlend, some of the coarse materfal in the clays is belleved to have been rafted by glacial ice. Such materials are considered to be glaciomarine and are assigned to the Vashon group rather than the Capjlano. Ienses of laminated materiel that lie gradationaliy beneath the Alberni clay are jaentical in occurrence to similar materials that lie between the Vashon till and superincumbent clay in the coastal lowland and between till and stony clay of the Dashwood group. As outlined in connection with the marine deposits of the coastal lowland, these materials may have been deposited in a narrow zone of fresh water beneath glacial ice where a floating, tidal ice shelf met the grounded part of the glacial mass. 


\section{Marjine Veneer}

A thin veneer of stony and clayey marine materials covers the till, bedrock, and local ice-contact gravels that form the slopes, hills, and rolling ground of the floor of Alberni Valley. These deposits are much less varied and much less distinctive than the marine veneer deposits of the coastal lowland. Generally they are 1 to 5 feet in thickness.

In most places, the veneer consists of unstratified, loose, stony, loamy materiel on slopes and hill tops, and of clay in depressions. In the eastern and central parts of the valley, where the till has a loam- to clay-loam matrix, the stony slope phase of the veneer is a stony loam that differs but little in texture from the underlying till, sl though commonly, the presence of lenses of pebble gravel within the stony loam provides a basis for its distinction from disaggregated till which has not been subjected to wave washing. In the western part of Alberni Valley, where the till is more sandy than elsewhere, the stony slope phase of the veneer is partly stony sandy loam similar to the till. Depressions here as in the rest of the valley are floored by a veneer of clay. The uppermost part of some of the gravelly icecontact deposits of Alberni Valley includes local bodies of pebbly loamy material and of clay containing casts of marine shells. The presence of these clayey lenses is an indication that the surface zone of the ice contact deposits has been reworked by merine action. 
The marine veneer of Alberni Valley appears to consist of a mixture of shoreline and sea-bottom deposits. The stony loamy material that makes up the greater part of the veneer seems to be the result of wave modjfjcation of till. In some pleces wave action seems to have effected very little change in the till; elsewhere it has washed some of the fine clayey material in the surface some downslope into depressions leaving a surface veneer on the slopes enriched in sand and stones; and, here and there, bave washing has concentrated distinct gravelly layers in the slope veneer. Gravelly, loamy materials resting upon lighter textured till or gravel are believed to have resulted from mixing of a thin layer of marine mud with the uppermost part of the till or gravel by frost action, roots, or other agencies in the modern soil zone.

\section{Shoreline Features}

Beach ridges, beach terraces, and deltas are locally associated with the abandoned marine deposits in Alberni Valley but are far less abundant here than on the coastal lowland. Successions of abandoned deltas a few hundred feet across border both Winder Creek, which enters Sproat Lake 2 miles west of Kleek-. oot, and Rogers Creek. Single deltas have been found adjacent to two of the tributaries of Cherry Creek. The Rogers Creek deltas consist of only a few feet of sandy pebble gravel and are rather poorly formed. Gravel pits in the winder Creek deltas and one of the Cherry Creek deltas reveal that each consists of a single set of top-set and fore-set beds of pebbly to cobbly gravel 
15 feet to 40 feet in thickness. Sandy bottom-set beds beneath one of the Winder Creek deltas have yielded casts of twigs and of marine pelecypod shells. The inland edge of the highest delta terrace at Winder Creek is 265 feet above present sea-level while the trio delta terraces at Cherry Creek are 300 feet above the present sea-level.

The eastermmost part of the Great Central ice-contact terrace and the pitted sandy terrace east of the mouth of Spaht Creek are believed to be deltajc deposits that formed where glacial streams entered the sea. These have been discussed in connection with the Vashon group.

Abandoned beach forms have been recognized in only a very few places in Alberni Valley but others are probably concealed by the forest. A shoreline terrace surrounds the till ridge between the power line and the logging rajlroad south of Roger.s Creek. This terrace is about 50 feet wide and consists of a wave-cut, boulder-strein notch in the till bordered on the downslope side through part of $\mathbf{i t s}$ length by a pebbly wave-bujlt terrace. It is about 300 feet above the present sea-level. A low, pebble gravel ridge that probably is a beach bar has been traced several hundred feet northwest and southeast from the road intersection 1.4 miles south 20 degrees east from Bainbridge. The gravel comprising this ridge is poorly sorted and less than 5 feet thick. The ridge adjoins the easterm, upper edge of the Alberni clay and lies between 300 and 310 feet above the present sea-level. Sjmilar gravels that also appear to be shore deposits occur at the same 
elevation at the road intersection 1 mile west of Bainbridge. A low scarp interpreted as a wave-cut cliff lies a few hundred feet east of Spaht Creek where the limit of marine submergence as shown on Plate IA is east of the creek. The higher ground to the right of the scarp as illustrated in Figure 65 consists of till. The stony area in the foreground below the scarp is surfaced by bouldery, sandy clay that grades into more normal Alberni cley farther from the scarp. The base of this scarp is between 320 and 340 feet above sea-level.

\section{Extent of Marine Submergence}

The highest marine features in Alberni Valley are about 300 feet above the present sea-level and between 150 and 200 feet lower than the marine limit on the coastal lowland. Because of the nondescript nature of the marine veneer in Albermi Valley, the limit of marine submergence is not clearly marked. The marine boundary show in Alberni Valley on the geologjcal map (Plate IA) is based largely on the highest occurrences of Albernj clay and is to be considered only as an approximation. The beach features outlined above, the Cherry Creek deltas, and the highest delta along Winder Creek are approximately at the same elevation as nearby highest occurrences of Albernj clay and may well have been formed at the highest stand of the sea. Along the east side of the valley from the south edge of the map to Beaver Creek, these shoreline features as well as the highest marine clays indicate submergence of 300 feet. At the western edge of Alberni Valley 


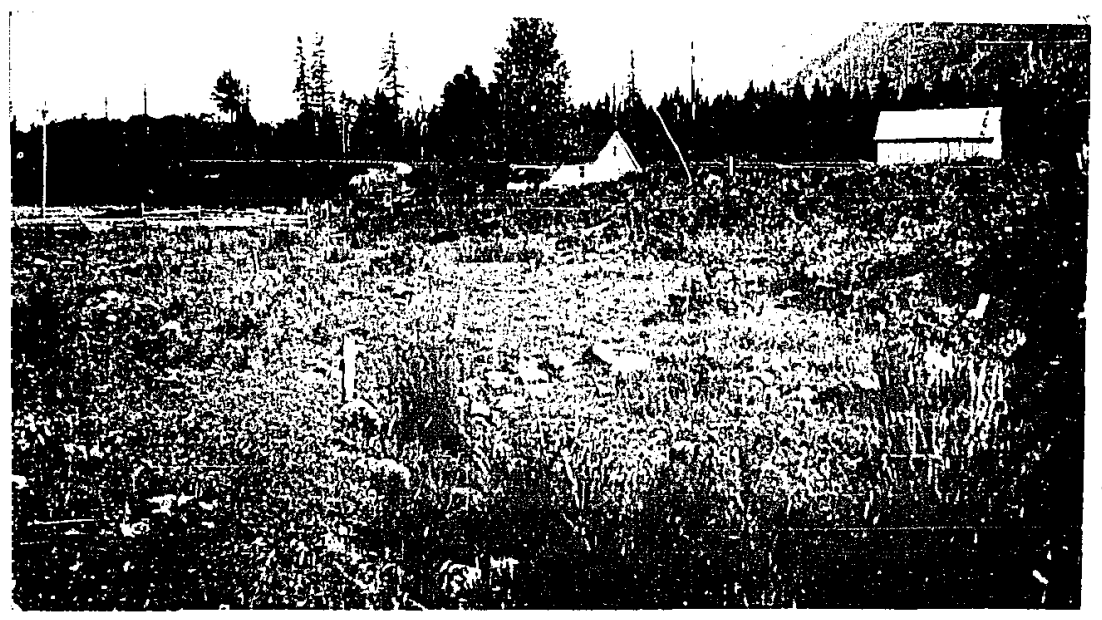

Fi gure 65. Near Spaht Creek, Alberni Valley. The 10-foot scarp extending from the automobile to the midale of the left side of the photograph $f \mathrm{~s}$ interpreted as a maxine wave-cut cliff. See text for further detajis.

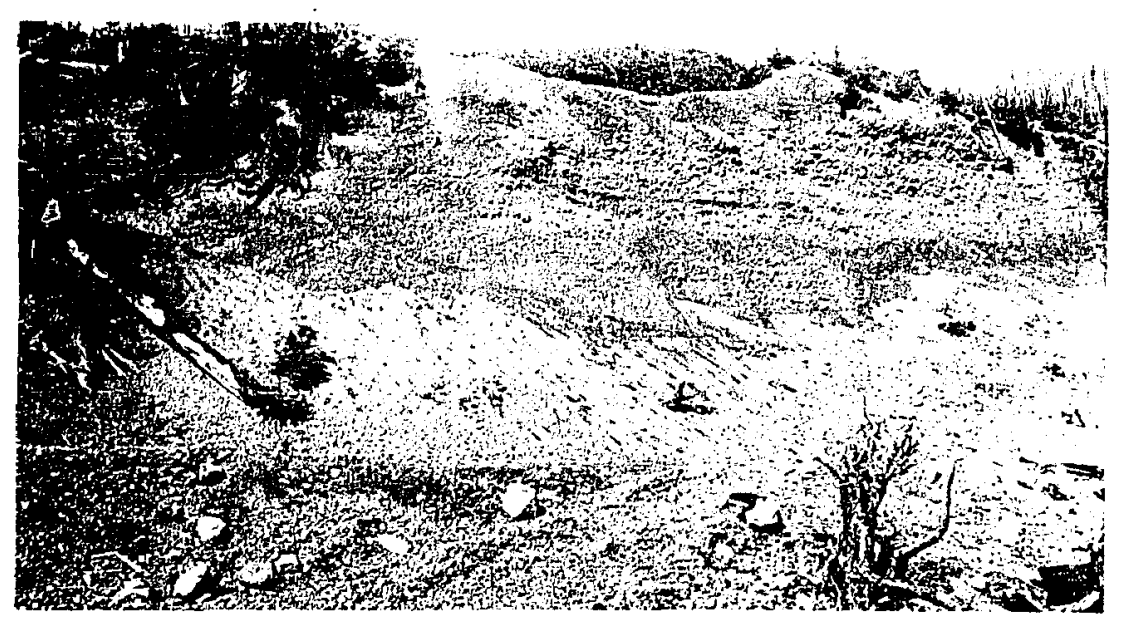

Fj gure 66. Alluvjal fan gravel, Rosewall Creek Valley. The cut bank is about 50 feet high. 
north of Sproat Lake both the highest clays and the highest delta at Winder Creek are between 260 and 270 feet above the present sealevel. In the northeast part of the area of marine overlap near Spoht Creek, the highest clays and the cut shoreline illustrated in Figure 65 are about 330 feet above the present sea-level. These elevations were determined by Paulin Altimeter and may be in error by several feet but they certeinly are accurate enough to indicate that the highest marine features in the various parts of the valley are not at the same elevation. Possibly, the features recorad do not represent a single marine level but, alternatively, the hlghest marine features may be tilted relative to the present stand of the sea. If, as seems likely, the highest marine features in Alberni Valley and on the coastal lowlend were formed at about the same time, the difference between thej $r$ elevation in Albermi Valley and on the coastal lowland provides more concrete evidence of tilting.

\section{Fluvi el Terrace Deposits}

Extensive terrace-topped deposits of gravel and sand containing lenses of marine clay are found within the valleys of Sproat, Stamp, and Somass Rivers a few tens of feet above the modern river floodplains. The terraces seem to be remnants of a single surface that sloped at about the same gradjent as the present valley floor. The surface is about 100 feet above sealevel at the junction of Stamp and Sproat Rivers and 30 feet 
above sea-level at the head of Alberni Inlet. As outlined in connection with the Somass ice-contact gravels of the Vashon group, some of the gravelly materjals beneath the terraces are truncated remnants of glacial ice-contact deposits but others Ife conformebly beneath the terrace surface and appear to be genetically related to it. These latter materials (termed "terrace deposits" in the following) are a few feet to several tens of feet in thickness and consist mainly of pebbly sand, sand, and sandy gravel. They contrin a few beds of silt. Lenses of clay and of till-like pebbly, gritty clay occur within the terrace deposits, rest upon their surface, and separate them from the underlying till. Stratification of most of the terrace deposits is undulatory but more or less horizontal, al though locally, gravels with a fore-set stratiflcation dipping down the valley lie beneath the horizontally bedded materials.

Miss Wagner of the Geological Survey of Canada has identified 11 spectes and genera of marine invertebrates in three collections of shell casts from clayey lenses associated wi th the terrace deposits. She reports (Wagner, 1954) that the equivalent lati tude of these assemblages range from 61 to 63 degrees (that is in the southern Bering Sea). A few imprints of leaves are assocjated with the shell casts and others have been found in silty, apparently non-marine beds of the terrace deposits. These imprints have been grented casual inspection by several botanists but no definjte identifications have been made. Most of the 
imprints are of paired pine needles and of a type of leaf very. suggestive of Dryas. One leaf imprint is simjlar to alder and another appears to belong to a member of the Ericacae. Dryas l.jves under climatic conditions consiaerably cooler than those sea-level in the area today and $i$ t.s presence (assuming the fdentification to be correct) confirms Miss Wagner's climatic inferences cited above.

These intermingled fluvial and marine deposits may have accumulated where the ancestral river entered the head of Alberni Inlet just as similar deposits are forming today at the mouth of Somass River. These deposits are found for more than 4 miles along the valley and their top, terraced surface drops about 80 feet in that distance. Consecuently, if they originated as suggested above they must have accumulated as successive increments as the shoreline migrated down the valley during an interval of dropping sea-level. An alternative explanation for the occurrence of marine materials in the terrace deposits is that the marine lenses accumulated on top of earljer fluvial deposits during an interval of rising sea-level and later were burled by another set of fluvial sands and gravels as sea-level dropped towards its present position.

CAPILANO DEPOSITS OF THE MOUNTAINOUS PARTS OF THE AREA

The Capilano group is represented in the mountains by abandoned lake deposits, fluvial terrace deposits, terraced alluvial fans, and landslide and talus debris. These are found 
principally in the mountain valleys although, as shown on the geological map, a few terraced alluvial fans are found along the mountain slope bordering the coastal lowland while talus and landslide deposjts (some of which belong in the Capilano group and some in the Saljsh group) mantle the base of the steep northeast wall of Alberni Valley. Distinction of these Capilano group materials from glaciofluvial, glacjolacustrine, and glacial landslide deposits of the Vashon group, on the one hand, and from the modern Salish deposits, on the other hand, is far from clearcut. Abandoned lake features surround. Horne Lake and Cameron Lake and are to be found here and there in other mountain valleys. The presence of former high lakes in the Horne Lake Valley is recorded by local clay and silt deposits up to 100 feet above the present lake level, by a few small gravel terraces 50 to 100 feet above the 1ake, and by extensive, apparently deltaic terraces in Qualicun River Valley $l^{\frac{1}{2}}$ to 2 miles upstream from the lake and 100 to 150 feet above its present level. Around Cameron Lake, small abandoned del tas bordering the mountainside streams, pebbly beach terraces, and accumulations of stratified sand and silt bear record of former lakes higher than the present one. The most prominent shoreline features are about 50 feet above the moderm lake level. As suggested in connection with the jce-contact deposj ts of the Vashon group, it is not know which of the raised lacustrine deposits in the Cameron Lake and Horne Lake Valleys were fomed in glacial 
ice-dammed lakes (i.e. belong to the Vashon group) and which accumulated in higher postmglacial lakes that existed before the Valley outlets had been cut down to their present position. Constructional fluvial terraces have been found in a few places in the mountain valleys. Among the most prominent are terraced deposits of cobbly, pebbly, and sandy gravel along Qualicum River about 2 injles upstream from Home Lake. As mentioned above, they appear to be partly deltajc and probably are related to a former higher level of Home Lake. Most other accumulations of fluvial deposits in the mountain valleys are found upstraam from bedrock hills that formed knickpoints in the gradient of the former streams. Numerous, small, steep, terraced alluvial fans are to be found in the mountainous parts of the map-area, principally where streams in smell, steep valleys flow out into the larger valleys or onto the lower, less steep parts of the mountain slopes. They are especially well displayed along the sides of Rosewall Creek Valley (see Figure 44). The abandoned alluvial fans consist of poorly sorted, cozrse, angular gravel that, on large clean faces displays indistinct bedding planes perallel to the fan surface (see Figure 66). On small exposures, the stratification is not evident and the fan material may be readily mistaken for till. Some fans include "pedimented" areas consisting of a lag veneer of stones resting on till. 
Landslide and talus deposits lie at the base of most of the steeply sloping hillsides of the region. Some appear to have been associated with retreat of the glaciers and on this basis belong in the Vashon group (see glacial landslide deposits of the Vashon group); some of them seem to have forned at about the same time as adjoining fans, terraces, etc. of the Capilano group; while others clearly are modern Saljsh group deposjts. Many of them, however, are not clearly assignable to one or another of these groups. These slope deposits range from collections of loose, angular blocks of rock to muddy materials very similar to till or alluvial fan deposits. Locally they attain a thickness of several hundred feet.

\section{EVENTS RECORDED BY THE CAPILANO GROUP}

The marine and fluvial deposits of the lowland parts of the map-area record changes in the relative position of land and sea during deglaciation and since disappearance of the glacial jce. The nature and distribution of these deposits were controlled In large measure by these elevation changes. The varied Capjlano group deposits of the mountainous parts of the area have not been studied in sufficient detail to permit determination of the events that controlled their deposition. Al though many of them formed along the headwaters of the streams that built the sea-shore deltas very few of them seem to be related to changes of stream gradient consequent upon changes of sea-level. 
The sea appears to have stood at its maximum posjtion against the land both in the Georgia depression and in Alberni Valley during retreat of the glacial tongues that occupied these valleys during the waning stages of the last glaciation. As outlined in the discussion of the Vashon Eroup, this conclusion is based upon the existence of ice-contact deltaic forms whose upper surface coincides with the upper linit of marine submergence. When the sea stood at this level relative to the land, glacjomarine deposjts accumulated near the glacial front while normal marine materjals formed elsewhere. Probably glaciomarine deposition ceased before the sea had dropped more than a few tens of feet below its maximum stand.

Most of the marine and deltajc deposits are suggestive of progressive emergence of the land from the sea. Thus, in most of the marine deposits, there is no evidence of superposition of bottom materials on shore materials. Commonly in delta successions, there is evidence that the stream that bujlt a particular delta eroded parts of adjoining higher deltas. On the other hand, a few deposits seem to Indicate that at least one interval of sea-level rise took place. For instance, "fossil" sea cliff deposits on Denman Island appear to record a rise of sea-level to at least 150 feet above its present position after sea-level had fallen to about $j$ ts present stand. An interval (or intervals) of sea-level rise is also recorded by the superposition of several series of top-set and fore-set beds in a few abandoned deltas. In Alberni Valley, the intermingled 
fluvial and marine materials in the Somass River terrace deposits may possibly record a sinilar sea-level fluctuation after the water level had dropped to within a few feet of $i t s$ present stand. The changes in the relative positions of land and sea that are recorded by these Capilano deposits probably were largely the result of isostatic earth movements conseçuent upon melting of the $i c e$ sheet, al though the net displacenent must also have involved eustatic changes of sea-level and local (probably minor) fault movements. The greater amplitude of the land-sea movements in the coastal lowland than in alberni Valley, and the small differences in the hej ght of the limit of submergence wi thin Alberni Valley are in agreement wi th the tilting of the land that, theoretically, would be expected to result from isostatic adjustments consequent upon melting of the glaciers. A warming of the waters of Georgia Strajt and Alberni Inlet must have taken place between the inj tial marine deposition along the retreating glacial margin and modern times. Nonetheless, all the assemblages of marine invertebrates from the abandoned marine and glaciomarine deposits that have been studied by Miss Wagner (Wagner, 1954) represent only a narrov range of condi tions, similar to those in the southern Bering Sea and the Gulf of Alaska. today. The absence of assemblages recording condi tions intermediate between those in the Gulf of Alaska and those in the area today may merely reflect incomplete sampling. Alternatively, distribution of marine invertebrates in the waters 
of the British Columbia-Alaska coast during earljer stages of the post-glacial interval may not:have been exactly analagous to their present distribution, particularly in view of the present small difference in sea-water temperature between the Gulf of Alaska and Georgia Strait (Fleming, 1955, Figures 17 and 19). A third possibjlity is that the infered warming of the sea waters took place after accumulation of the abandoned marine deposits of the Capilano group, either while the sea-level has occupied its present position or during an interval of lower sea-level. 
CHAPTER 9

\section{SALISH GROUP}

The Selish group comprises modern deposits that are presently being formed. As outlined on the stratigraphic chart (Figure 10) it is represented in the map-area by channel, floodplain, and alluvial fan deposits along the modern streams; deltajc deposits where these streams enter lakes and the sea; shoreline deposjts bordering both sea and lakes; swainp deposits; landslide deposits; talus; and colluvium. The multitudinous deposjts being accumulated in the area by man and his machines should also be added to the list. Underwater marine and lake deposits have been arbitrarily omitted from the present classification. These materials are assigned to the Salish group rather than the Capilano on the grounds that the depositional units to which they belong (that is deltas, alluvial fans, etc.) are being added to at present, have been added to wi thin the last century or so, or may be added to in the future by the original depositing agent. On the accompanying geological map (Plate I) marine shoreline deposits up to 5 feet above normal high tide line and stream deposits 10 to 15 feet above summer water level have been included in the Salj sh group. The Indian middens have been assjgned to the group, even though thej $x$ accumulation has ceased, on the grounds that, for the most part, they are essentially shoreline deposits formed at the present stand of the sea. The word Saljsh is the name of the Indian 
nation of the Georgia depression; its geological application to these moderm deposits has been suggested by Dr. J.E. Armstrong of the Geological Survey of Canada (Armstrong and Brown, 1953).

The individual depositional units comprising the Salish group of the map-area are mostly less than a mile across. They range from a few inches to several hundred feet in thickness. The component materials are extremely varjed in texture but are predominantly gravelly. No attempt will be made to describe them in detajl here.

The Salish group is a formational rather than a time unit. Some of the components of the group (for instance, swamp deposits in ground moraine depressions) have been accumulating continuously since deglaciation, whereas others originated within the last century. The marine shore and marine delta deposits of the Salish group have accumulated during the interval since the establishment of the present relative positions of land and sea. This interval must have been of considerable duration to permit the cutting of the broad marine platforms that are found along parts of the present shoreline of Georgia Strajt. Some of these platforms, which have been cut into till and other resjstant surficial materials and into shale and sandstone of the Nanaimo group, are several hundred feet to 1000 feet in width. These wave-cut platforms seem to represent a greater amount of erosion than most of the abandoned terraces of the Capjlano group that have been cut into similar materials and that would have had similar exposure to waves. On the other hand, some of the 
erosion evident in the platforms along the present shore may possibly have taken place during the early period of low sea-level recorded on Denman Island ( indjeation that the land has occupied $j$ ts present posjtion relative to the sea for more than 2500 years has recently been provided by a radiocarbon dating of archaeological materjals. Charcoal from the lower part of a midden at Locarno Beach in the city of Vancouver has been dated by the radiocarbon method as 2430 ( 163 ) years old (Borden, 1954, p. 26; 1950, p. 14). This midden borders the shore of the Strajt of Georgia and, in part at least, is an integral part of the moderm sea shore deposjts of the Sallsh group. 
CHAPTER 10

\section{HISTORICAL SUMMARY}

The surficial deposits and glacially sculptured landscspe with which this report is concerned are superimposed upon lowlands, uplands, and valleys not greatly different from those presently comprising the topography of east central Vancouver I sland.

The oldest surficial deposits that have been recognized are the sub-Dashwood sands and silts, which appear to have accumulated on a river floodplain or in a lake on the floor of the Georgia depression. The duration and climate of the nonglacjal interval during which they were deposited are not known. They may be of Illinoian age or perhaps older. Although older Pleistocene deposits have not been found, they may nonetheless be present in the coastal lowland.

After the accumulation of the sub-Dashwood sands and silts, glacjal ice invaded the region and deposited the till sheet of the Dashwood group in the Georgia depression. This glaciation probably took place during the Illinolan age. Little is known of the extent of the glacial ice or of $j$ ts direction of flow, although this glacjation may have been simjlar to the later, Wisconsin glaciation, about which we know much more. While this early glacial mass in the Georgia depression was melting, the sea stood at least 250 feet above its present level and glaciomarine stony clays as well as normal marine deposits accumulated on the Dashwood till. 
This deglaciation and marine inundation were followed by a major non-glacial interval that mey have been equjvalent to the Sangainon age. During the early part of this interval, sea-level dropped to $j$ ts present position or lower while silts, sands, gravels, and swamp deposits accumulated along successive marine shorelines and in stream channels and floodplains extending inland across the emerged sea-bottom plain. Driftwood and soil profiles in these shoreline and stream deposits record a climate cooler than that of today and probably sjmilar to that of southerm coastal Alaska. On the basis of radjocarbon dating, peat from one of the swamp deposits was formed more than 30,000 years ago. During the ensuing part of the non-glacial (Sangamon?) interval, a thick succession of sands (Quadra sands) accumulated, apparently as a fluvial, estuarine plain deposit that filled the northern part of the Georgia depression to at least 300 feet above the present sea-level. Then the sands were largely removed again by streams during a. Iong interval of degradation and, apparently, of lower sea-level. The climatic condj tions during accumulation of the sands and during the subsequent erosjon are not known.

The wisconsin age appears to include a single major interval of glaciation during which the tills, ice-contact deposits, landslide deposjts, and glaciomarine deposits of the Vashon group accumulated. During the clinax of this glaciation, an jce sheet covered all the map-area and surrounding country except the summit of Mount Arrowsmi th and flowed south to southwest from the Georgia depression across the Vancouver Island mountains. 
$-250-$
When the jce surface dropped below the mountain crests, the jce sheet separeted into a network of glacjer tongues in the mountain valleys. Some of these, in through valleys like those of Horne Lake and Cameron Lake, continued active southwestward movement for a time as "outlet" glaciers of the lorge glacial body that still occupied the Georgia depression. The remnant glacial ice in the valleys heading on the east side of the mountains apparently stagnated when the ice surface dropped below the valleyhead divjdes. Mountainside strems built alluvial fans against the shrinking $i$ ce masses in the mountain valleys while $j$ ce marginal rivers and lakes built end cut narrow terraces along the valley walls.

After the ice surface had dropped below the crest of the Beaufort Range, and perhaps even earlier, Alberni Valley wo.s occupied by a southwest-flowing glacjal body that was fed by a system of glaciers emanating from the highlands of Vancouver Island to the northwest. During deglaciation, the terninus of the Albemi Valley glacier appears to have wi thdrawn northeast ward up the valley and to have been bordered by marine water standing 300 feet above present sea-1evel.

After the climax of the Wisconsin glacjation, the Georgia depression was occupied by a glacjer that flowed southeastward across the coastal lowlands of the map-area parallel to the front of the Vancouver Island mountains. During deglaciation, as this glacier grew progressively thinner, streams flowed 
southeastward between the edge of the glacier and the lover part of the front slope of the Vancouver Island mountains. Locally, these streams flowed on, within, or beneath the marginal part of the glacjer. Other streams from the mountains joining with those along the ice edge. The ice-marginal streans deposited extensive terraced, pitted, and humnocky ice-contact gravels and sands along the inland edge of the coastal lowland and on the lower part of the adjoining hillside. The teminus of the strait of Georgia glacjer eppears to have retreatea northwestward and to have been bordered by marine water extending 450 or 500 feet above the present sea-level. Glaciomarine stony clays accumuIated on the sea bottom adjacent to this tidal glacjer front. Some of the ice-narginal streams entered the sea at the south end of the glacier terminus, where they deposited marine del tas that partly were bordered by water and partly were bujlt against remnants of glacjal jce.

A glecier flowed down Englishman River Valley during the latter part of the Wisconsin glacigtion and caused a northeastward diversion of the direction of glecial flow in the adjolning part of the Georgia depression. This glacier apparently coalesced with the Strajt of Georgla glacjer when the southerm edge of the latter stood 1500 or 2000 feet above present sea-level. Ice may have remained in the Englishman River Valley south of the Georgia depression after the terminus of the Strajt of Georgia glacier had retreated to the northwest. Meltwater streams associated with the Fingli shman River glacier bujlt several small 
eskers on the Inland part of the coastal lowlend adjoining knglishman River.

The Englishman kjver glacjer was fed by glacjers in cirques on Mount Arrowsmith. On the other hand, the snowline since the climax of the Wisconsin glacjation has never been low enough to pernit development of such circue or valley placiers on the lower, Beaufort Range.

The sea stood at its highest position relative to the land during the disappearance of the glaciers, when it extended about 450 or 500 feet above the present sea-level in Albemi Valley. Following deglaciation, sea-level fell to $i$ ts present position relative to the land although at least one minor sealevel rise appears to have taken place. On the basis of one radiocarbon dating (Borden, 1954, p. 26), the land and sea have occupied their present relative positions for more than 2500 jears. During the post-glacigl interval, extensive and varied marine deposits accumulated on the coestal lowland and in Albernj Valley. Molluscan assemblages in these deposits record a climate cooler than the present one and probably similar to that of southern coastal Alaska. Series of deltas have been formed where streams reached successive positions of the sea shore. Streams have cut successively lower beds, leaving river terraces, local floodplain deposits, and alluvigl fans perched on the valley walls, and lowering the level of some of the lakes. Landslide debris and other slope deposits as well as peaty swamp deposits have been 
accumulating in favourable places since disappearance of the glacial ice and withdrawal of the sea. 
Arnold, Ralph, and Hannibal, Harold (1913): The marine Tertiary Stratigraphy of the Ibrth Pacific Coast of America; Proc. Am. Phil. Soc., vol. 52, pp. 559-605.

Armstrong, J.E., and Brown, W.I. (1953): Ground-Water Resources of Surrey Municipality, British Columbia; Geol. Surv., Canada, Water Supply Paper 322.

Armstrong, J.E., and Brown, W.I. (1954): Late Wisconsin Marine Drift and Associated Sediments of the Lower Fraser Valley, British Columbia, Canada; Bull. Geol. Soc. Am., vol. $65, \mathrm{pp} .349-364$.

Bancroft, J.A. (1913): Geology of the Coast and Islands between the Strait of Georgia and Queen Charlotte Sound, B. C.; Geol. Surv., Canada, Mem. 23.

Berry, Edward $W_{0}$ and Johnston, W०A. (1922): Pleistocene Interglacial Deposits in the Vancouver Region, British Columbia; Trans. Roy. Soc., Canada, vol. 16, Sec. 4, pp. 133-139.

Borden, Charles E. (1950): Preliminary Report on Archaeological Investigations in the Fraser Delta Region; Anthropology in British Columbia, Wo. I, pp. 13-27.

(1954): Some Aspects of Prehistoric CoastalInterior Relations in the Pacific Northwest; Anthropology in British Columbia, No. 4, pp. 26-31.

Bostock, H.S. (1948): Physiography of the Canadian Cordilizera, with Special Reference to the Area North of the FiftyFifth Parallel; Geol. Surv., Ganada, Mem. 247.

Bretz, J.H. (1913): Glaciation of the Puget Sound Region; Washington Geol. Surv., Bull. 8 .

Broeker, W.S., and Kulp, J.L. (1955): New Radiocarbon Dates and Their Applications to Oceanography; Bull. Geol. Soc. Am., voI. 66, p. 1535 .

Buckham, A.F. (I947a): The Nanaimo Coal Field; Trans. Can. Inst. Min. Net., vol. 50, pp. 460-472.

(1947b): Preliminary Map, Nanaimo Coalfield, British Columbia; Geol. Surv., Canada, Paper 47-22.

Burwash, E.M.J. (1918): The Geology of Vancouver and Vicinity; the University of Chicago Press. 
Clapp, C.H. (1913): Geology of the Victoria and Saanich Map-areas, Vancouver Island, B.C.; Geol. Surv., Canada, Mem. 36.

(1914): Geology of the Nanaimo Map-area, B.C.; Geol. Surv, , Canada, Mem, 51.

(1917): Scoke and Duncan Map-areas, Vancouver Island; Geol. Surv., Canada, Mem.96.

Cummings, J.M. (1941): Preliminary Investigation into Possibilities for Producing Silica Sand from British Columbia Sand Deposits; B.C. Dept. of Mines.

Dawson, G. M. (1887): Report on a Geological Examination of the Northern Part of Vancouver Island and Adjacent Coasts; Geol. Surv., Canada, Ann. Rept. 1886, Vol. 2, pt. B, pp. 1-107.

(1890): On the Later Physiographic Geology in the Rocky Mountains Region in Canada; Trans, Roy. Soc. Caneda, vol. 8, Sec. 4, pp. 3-74.

Fleming, R. $H_{0}$ (1955): Review of the Oceanography of the Northern Pacific; International North Pacific Fisheries Commission, Bull. 2.

Flint, R,F. (1949): Glacial Geology and the Pleistocene Epoch; John Wiley and Sons, New York.

Fyles, J.T. (1955): Geology of the Cowichan Lake Area, Vancouver Island, British Columbia; B.C. Dept, of Mines, Bull. No. 37.

Guming, H.C. (1930): Buttle Lake Map-area; Geol. Surv., Canada, Sum. Rept., Pt. A, pp. 56-78.

Hansen, H.P., and Mackin, J.H. (1949): A pre-Wisconsin Forest Succession in the Puget Sound Lowland, Washington, $A_{m}$. Jour, Sci, vol, 247, pp. 833-855.

Hoadley, J.W. (1953): Geology and Mineral Deposits of the Zeballos-Nimpkish area, Vancouver Island, British Columbia; Geol. Surv., Canada, Mem. 272.

Holmes, C.D. (1941): Till Fabric, Bull, Geol. Soc. Am, vol. 52, pp. 1299-1354.

Jahns, R.H. (1943): Sheet Structure in Granites; Its Origin and Use as a Measure of Glacial Erosion in New England; Jour. Geol., vol. 51, pp, 71-98. 
Johnston, W.A. (1923): Geology of the Fraser River Delta Maparea; Geol. Surv., Canada, Mem. 135.

Krumbein, W.C. (1939): Preferred Orientation of Pebbles in Sedimentary Deposits; Jour. Geol., vol. 47, pp. 673-706.

Krumbein, W.C., and Pettijohn, F.J. (1938): Manual of Sedimentary Petrography; D. Appleton-Century, New York.

LeRoy, 0.E. (1908): Preliminary Report on a Portion of the Main Coast of British Columbia and Adjacent Islands included in New Westminster and Nanaimo Districts; Geol. Surv, , Canada, Rept. No. 996.

Mackenzie, J.D. (1923): The Alberni Area, Vancouver Island, British Columbia; Geol. Surv., Canada, Sum. Rept. 1922, pt. A, pp. 6I-67.

Mackin, J.H., Mullineaux, D.R., and Stark, W.J. (1950): Glacial Geology of Seattle; The Trend in Engineering, Univ, of Washington, vol. 2, pp. 19-21.

McConnell, R.G. (I914): Texada Island, B.C.; Geol. Surv., Cianada, Mem, 58 .

Newcombe, C.F. (1914): Pleistocene Raised Beaches at Victoria, B.C.; Ottawa Naturalist, vol. 28, pp. 107-110.

Peacock, M.A. (1935): Fiord-land of British Columbia; Bull. Geol. Soc. Am., vol. 46, pp. 633-696.

Pettijohn, F.J. (1949): Sedimentary Rocks; Harper Brothers, New York.

Pierce, W.D., and Draycot, W.M. (1948): Fossil Arthropods from British Columbia; Bull. South Calif. Acad, Sciences, vol. 47, Pt. I, pp. 2l-33.

Richardson, J. (1874): Report of Geological Exploration in British Columbia; Geol. Surv., Canada, Rept. of Prog. 1873-1874, pp. 94-102.

Schenck, H.G. (1945): Geologic Application of Biometrical Analysis of Molluscan Assemblages; Jour. Paleo. Vol. 19, pp. 504-521.

Stevenson, J.S. (1945): Geology and Ore Deposits of the China Creek area, Vancouver Island, British Columbia; Minister of Mines, B.C., Ann. Rept. for 1944, pp. 142161. 
Usher, J.I. (1952): Ammonite Faunas of the Upper Cretaceous Rocks of Vancouver Island, British Columbia; Geol. Surv., Canadz, Bull. 21.

Wagner, Frances J.E. (1954): Palacontology and Stratigraphy of the Marine Pleistocene Deposits of Southwestern British Columbia; Unpublished Ph.D. Dissertation, Stanford University.

Willis, Builey (1898): Drift Phenomens of Puget Sound; Bull. Gecl. Soc. Am, , vol. 9, pp. 111-162. 


\section{AUTOBIOGRAPHY.}

I, John Gladstone Fyles, was born in Vancouver, British Columbia, February 27, 1923. I received my primary and secondary school education in the public schools of that city. My undergraduate and early graduate training was obtained at the University of British Columbia, from which I received the degrees of Bachelor of Applied Science in 1946 and Master of Applied Science in 1950. While in residence at The University of British Columbia in the year 1946-47, I held an assistantship in the Department of Geology. During the years 1951-53, I undertook studies towards the degree of Doctor of Philosophy at the Ohio State University, specializing in the Department of Geology. I acted in the capacity of assistant in that department during the year 1951-52. 

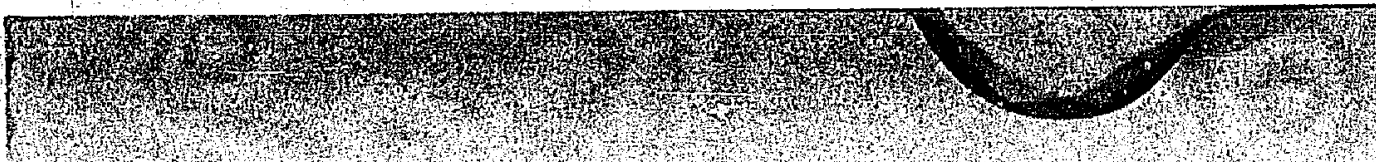

pockII

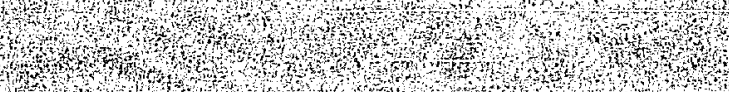

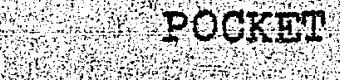

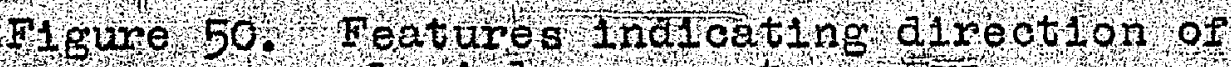
g1a o1al movement

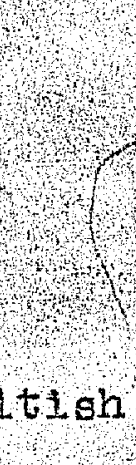

Plate IA Surflolal Geology, forne Lake, British Columbia

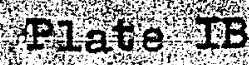

burficlal Geoloby, Perksville, Brittoh Coliambia

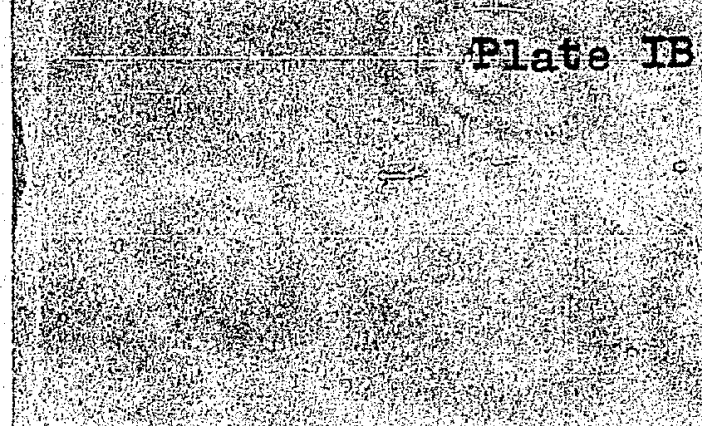



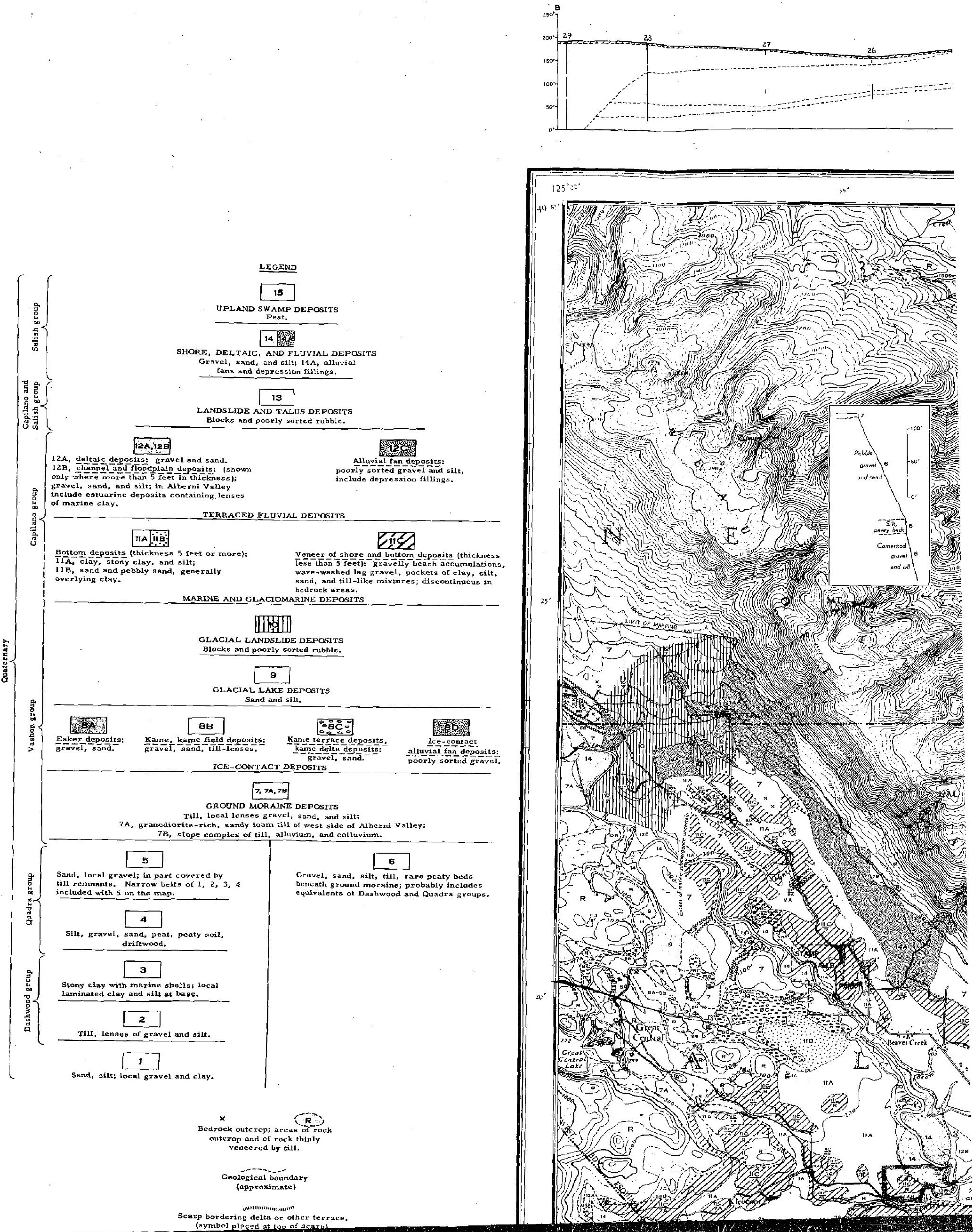

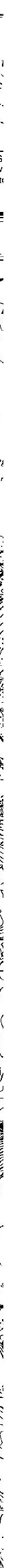

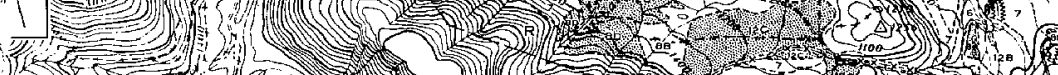
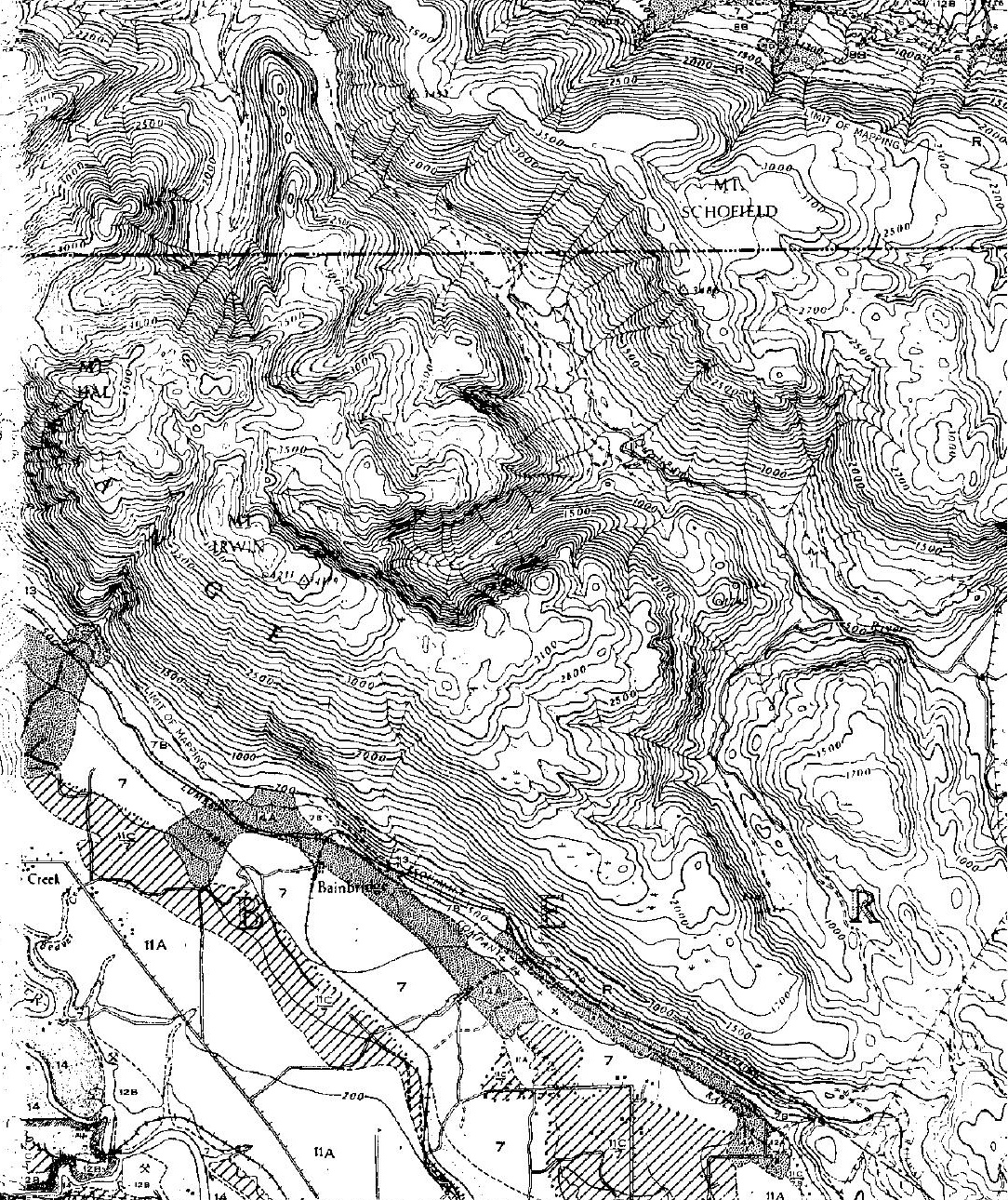


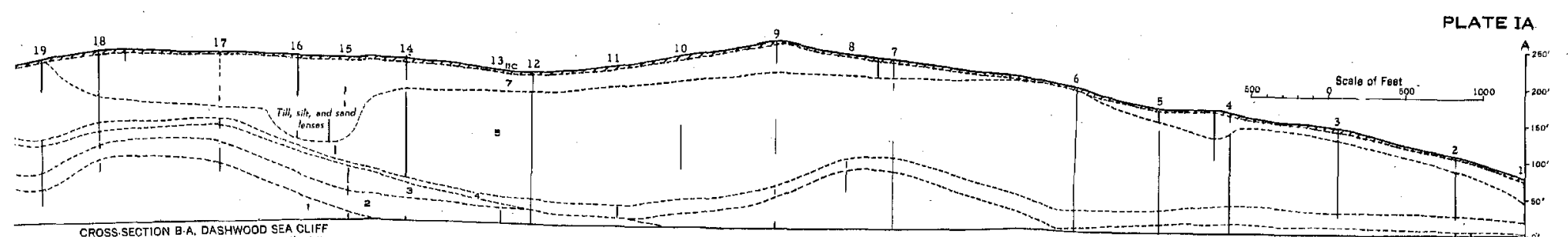

CROSS. SECTION B.A. DASHWOOD SEA CLLFF
Measured exposures shown by heavy vartical fines

and numberad serially from wast $t A$
Vertical exaguration $5 \times$

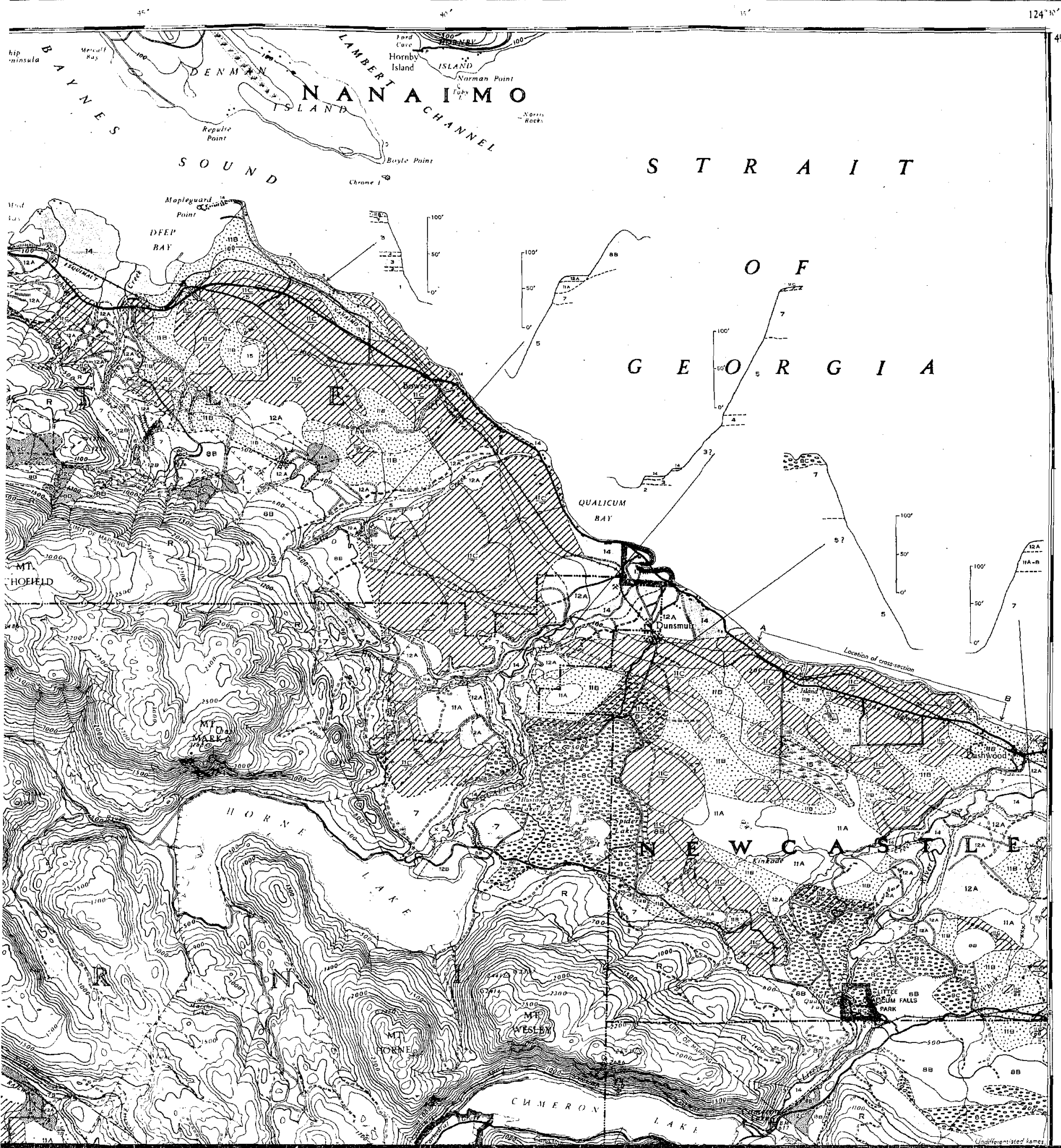




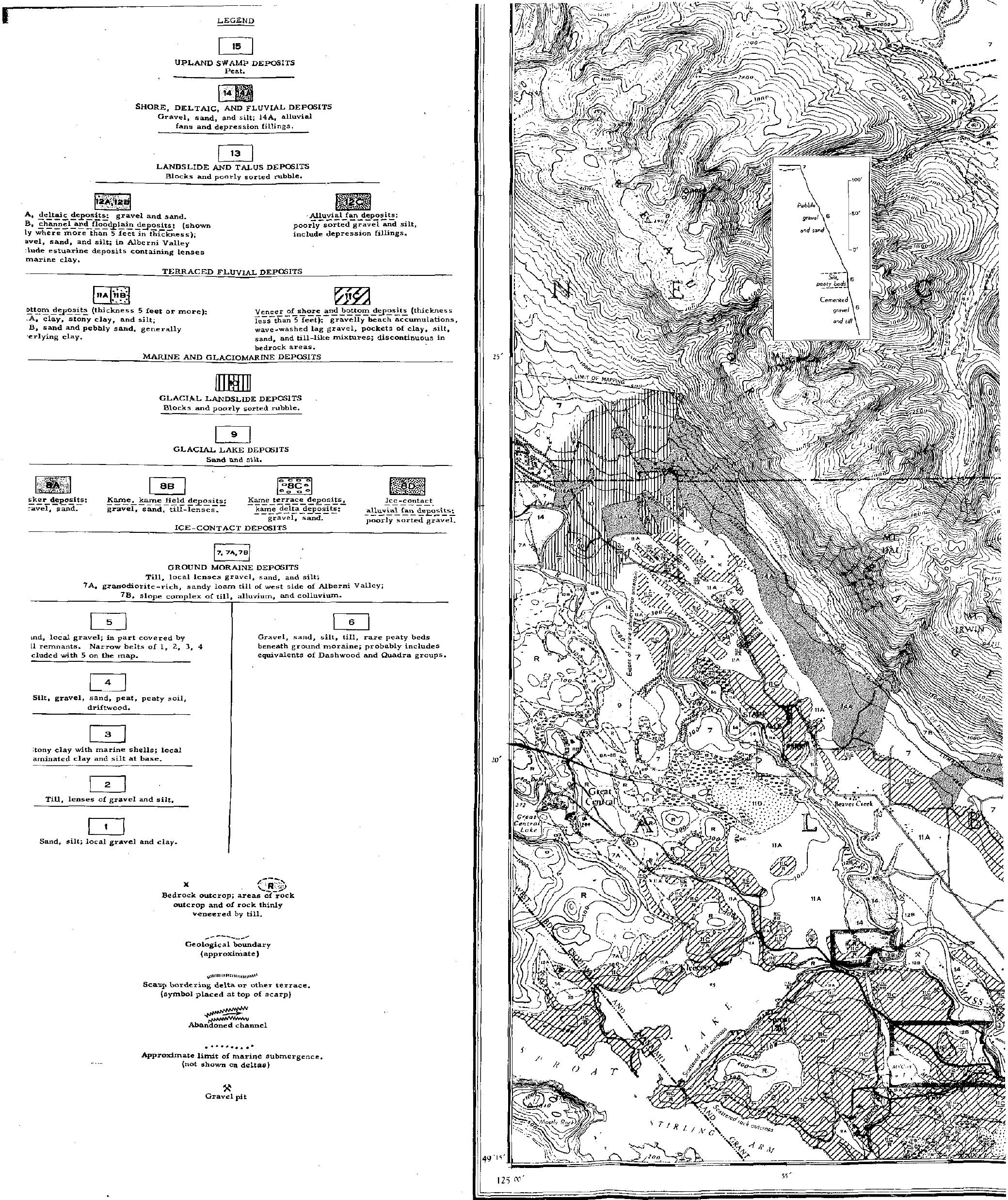



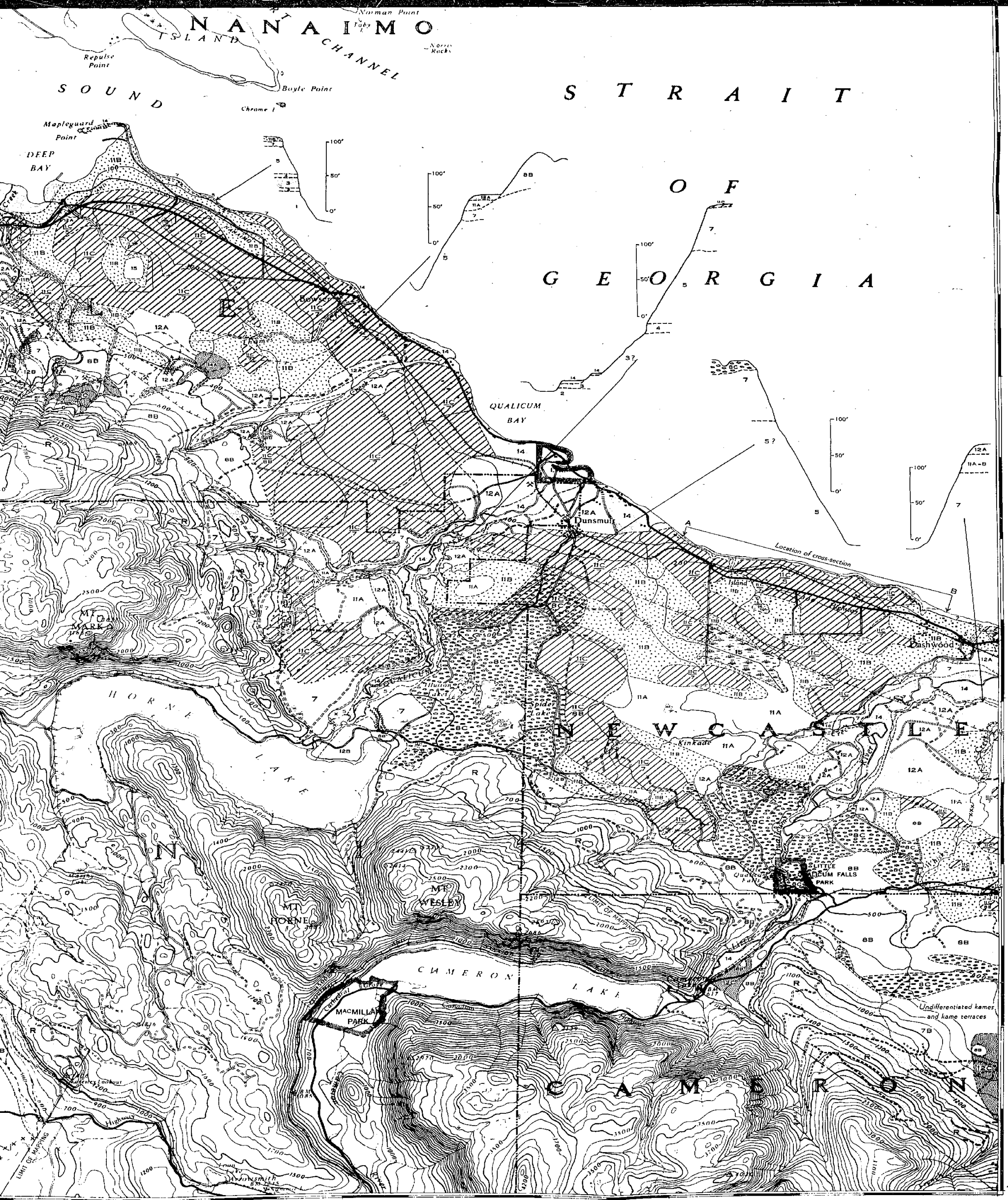


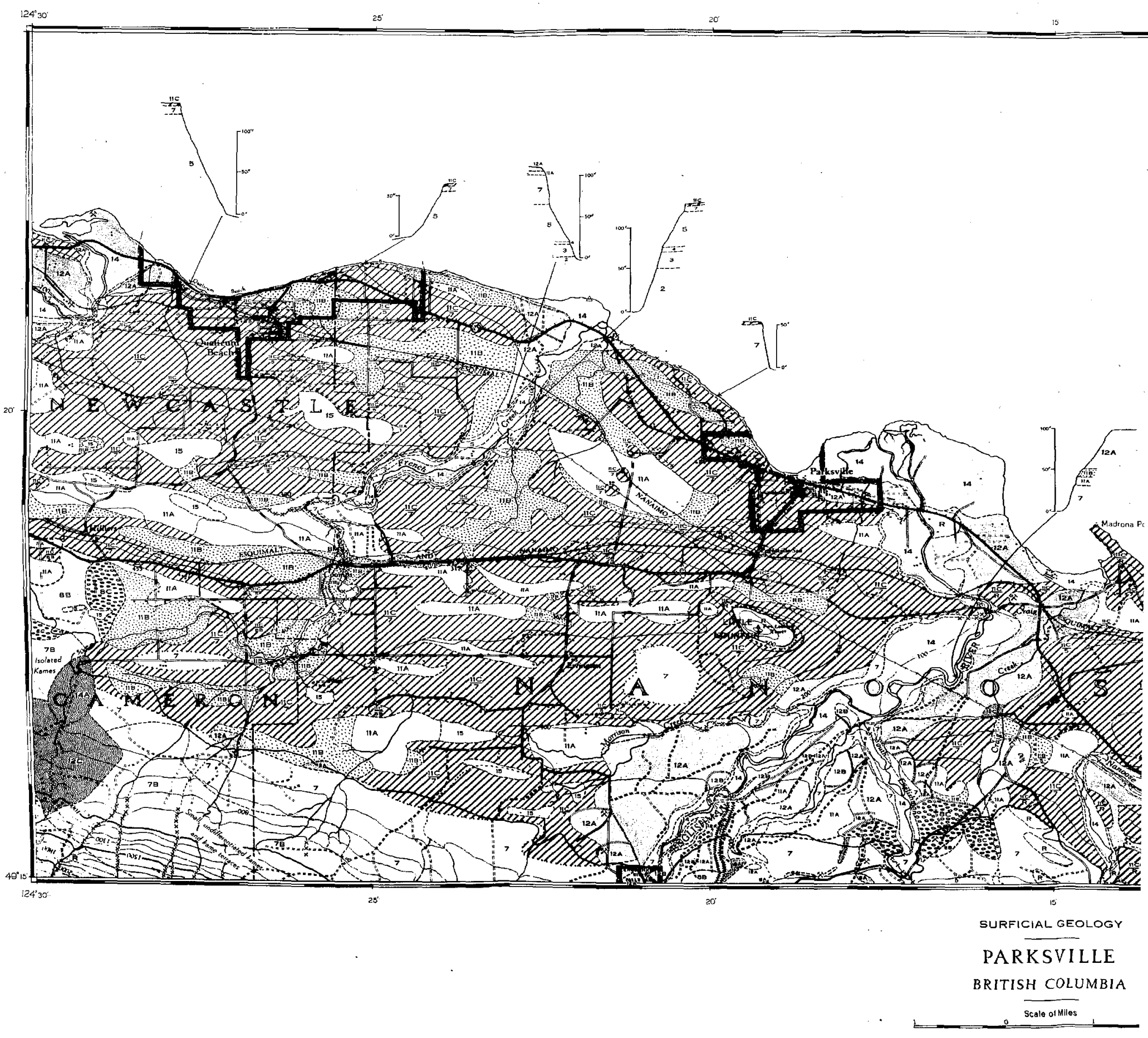




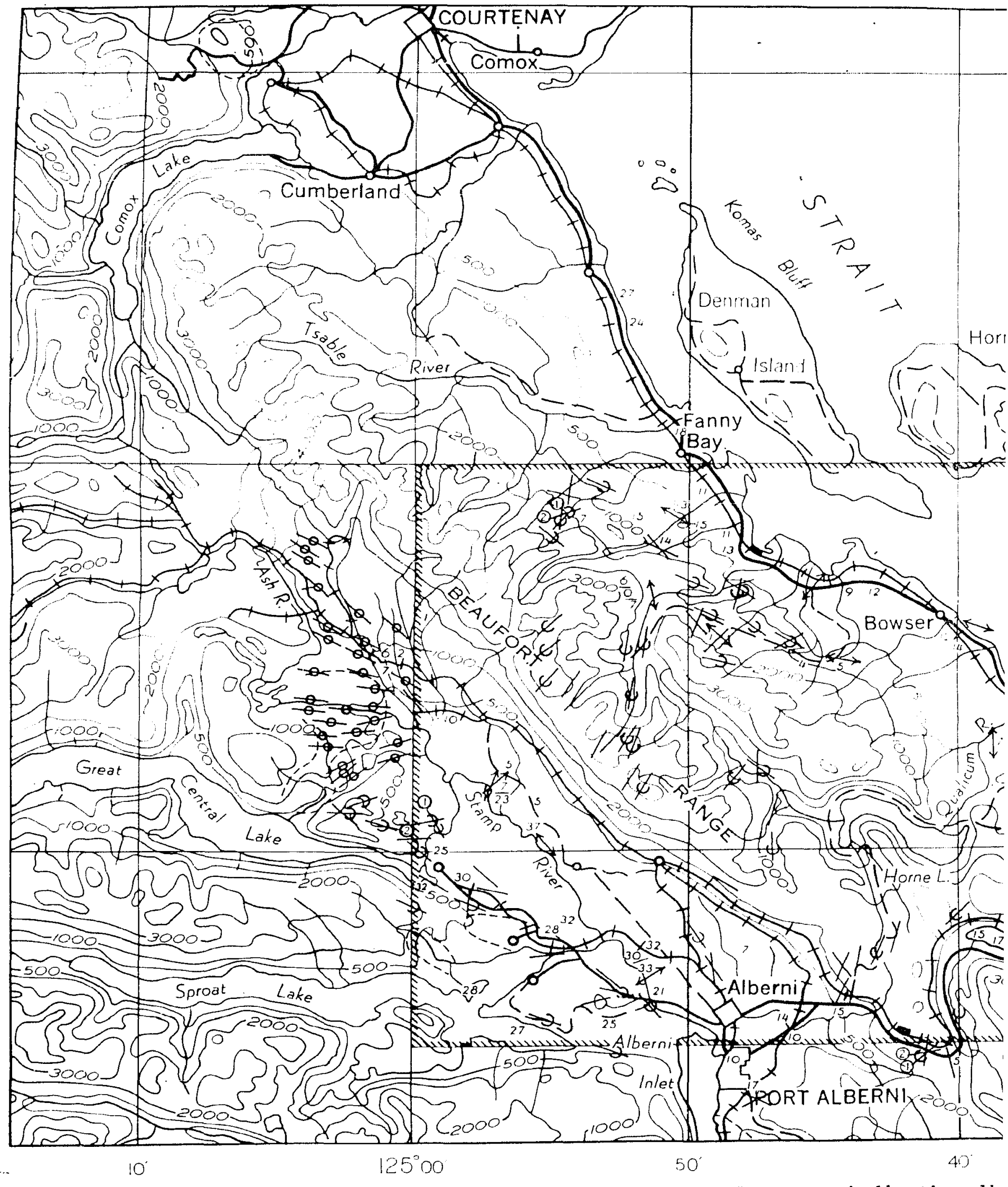

Figure 60. Features indicating dis 
Striae and grooves .....................

Stoss-and-lee surfaces, rochesmoutonnée, crag-and-tail forms; generally accompanied by striae ..........

Superimposed indicatorg of glacial movement revealing o 0 relative age, 1 older than $2 \ldots \ldots \ldots \ldots$

Drumlinoid ridges $\ldots \ldots \ldots \ldots \ldots \ldots \ldots$

Fabric orientations of till of the vashon group ........

Hornty

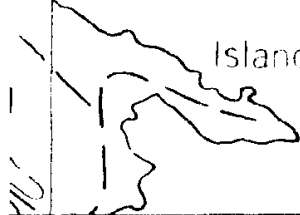

(1)

○ิ
Percentage of granitoid pebbles in till of the Vashon group. Superimposed figures separated by baxs indicate percentages above and below discontinuities within the till .................... $\frac{7}{3}$ Areas of granitoid rocks ...................

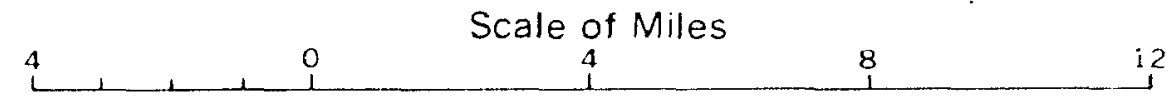

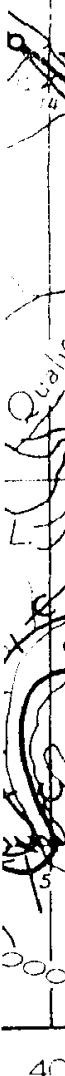

4

ing direction of glacial movement.

Dashwood

Beach
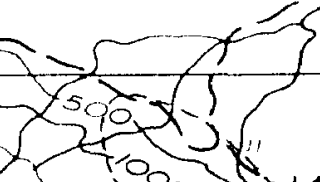

\section{$G E O P G / A$}

Qualicum
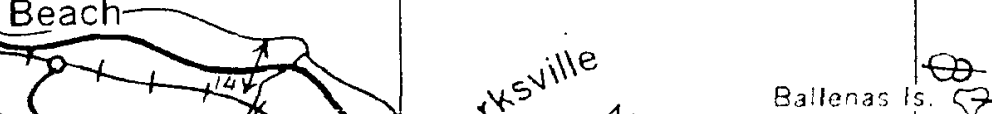

Ballenas is. $83-49^{\circ}$
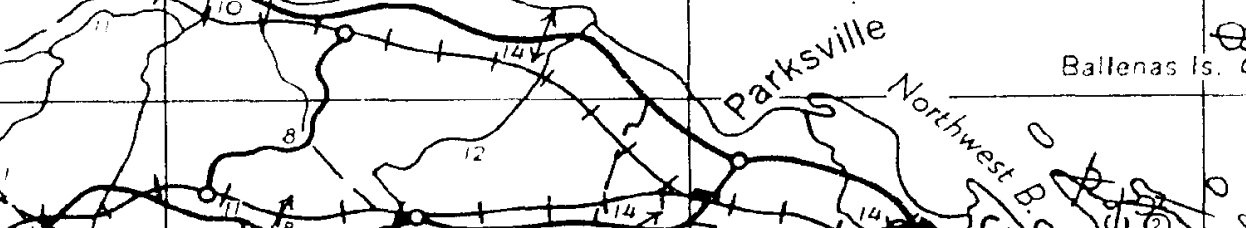